TALITA SAMPAIO CECCARELLI

\title{
PARADIGMAS PARA OS PROJETOS DE OBRAS MARÍTIMAS NO CONTEXTO DAS MUDANÇAS CLIMÁTICAS
}

\author{
Dissertação apresentada à Escola \\ Politécnica da Universidade de São Paulo \\ para obtenção do título de Mestre em \\ Engenharia.
}

São Paulo 


\title{
PARADIGMAS PARA OS PROJETOS DE OBRAS MARÍTIMAS NO CONTEXTO DAS MUDANÇAS CLIMÁTICAS
}

\author{
Dissertação apresentada à Escola \\ Politécnica da Universidade de São Paulo \\ para obtenção do título de Mestre em \\ Engenharia. \\ Área de Concentração: \\ Engenharia Hidráulica \\ Orientadora: \\ Dra. Emilia Arasaki
}

São Paulo 
Este exemplar foi revisado e alterado em relação à versão original, sob responsabilidade única do autor e com a anuência de seu orientador.

São Paulo, 15 de junho de 2009.

Assinatura da autora

Assinatura da orientadora

FICHA CATALOGRÁFICA

Ceccarelli, Talita Sampaio

Paradigmas para os projetos de obras marítimas no contexto das mudanças climáticas / T.S. Ceccarelli. -- São Paulo, 2009.

$125 \mathrm{p}$.

Dissertação (Mestrado) - Escola Politécnica da Universidade de São Paulo. Departamento de Engenharia Hidráulica e Sanitária.

1. Hidráulica marítima 2. Defesa do litoral 3. Mudança climática I.Universidade de São Paulo. Escola Politécnica. Departamento de Engenharia Hidráulica e Sanitária II.t. 


\section{DEDICATÓRIA}

A Giorgio Brighetti (in memoriam), exemplo de ser humano. 


\section{AGRADECIMENTOS}

A Deus, pela presença constante em mais essa conquista.

A meus pais José Carlos e Anamaria, e meus irmãos Felipe e Bruno, que dividem comigo a alegria dessa vitória conseguida juntos. A todos da minha família, em especial à vovó Elza, pelo carinho e incentivo tão necessário nessa caminhada.

A meus amigos, em especial ao Query (Ricardo A.P. Silva) e à Lê (Letícia M. Oliveira) que me acompanharam nos momentos difíceis e de dúvidas.

Ao Júlio Astolphi, que sempre me transmitiu conhecimento, experiência de vida e profissional, o meu reconhecimento.

Ao Prof. Dr. Paolo Alfredini e Prof. Dra. Emilia Arasaki pela orientação dedicada e pela oportunidade de aprendizado.

Meus agradecimentos àqueles que muitas vezes, no anonimato, contribuíram para o êxito desse trabalho. 
"O mar não é um obstáculo, é um caminho." Amyr Klink 
O aquecimento global e conseqüente elevação do nível médio do mar constituem-se num desafio para a manutenção e o projeto das estruturas marítimas nas próximas décadas. Tanto as mudanças climáticas globais, quanto o fato das tempestades extremas estarem sofrendo substanciais alterações, têm profundas conseqüências para a sociedade, bem como para o meio ambiente. $O$ trabalho teve como objetivo apresentar e discutir esses aspectos climáticos e analisar os paradigmas para os projetos de obras marítimas, como as defesas costeiras e obras de estabilização para manter ou reconstruir os sistemas naturais (falésias, dunas, terras úmidas, praias), ou para proteger as construções e infra-estruturas costeiras (áreas urbanas, acessos de ligação, rodovias). Para isso, analisou-se o estudo de caso sobre a ocorrência de erosão costeira na Praia de Massaguaçu, cidade de Caraguatatuba no Estado de São Paulo, avaliando os projetos e obras realizados para o local, considerando as recomendações das políticas públicas existentes em nível internacional. Dessa forma, o trabalho foi concluído, apresentando as possíveis soluções para o problema de erosão ocorrido em uma região costeira, face à elevação relativa do nível médio do mar.

Palavras-chave: Hidráulica marítima. Defesa do litoral. Mudança climática. 
Global warming and the consequent increase of the mean sea level rise will be a challenge to the maintenance and development of offshore structures in the coming decades. Both global climate change and the fact that the extreme storms are experiencing substantial changes have profound consequences for the society and the environment. The study aimed to present and discuss these issues and analyze the climatic paradigms for offshore projects such as coastal defenses and the stabilization works to maintain or rebuild the natural systems (cliffs, dunes, wetland, beaches), or to protect buildings and coastal infrastructure (urban areas, access for connections, roads). To this end, it was analyzed the case study on the occurrence of coastal erosion on the beach of Massaguaçu, Caraguatatuba city in São Paulo State, the projects and works undertaken for the site were evaluated, considering the recommendations of the existing policies at the international level. Thus, the study was concluded, with the possible solutions to the problem of erosion occurred in a coastal region, given the increase on the mean sea level rise.

Keywords: Maritime hydraulic. Coastal protection. Climate change. 


\section{LISTA DE ILUSTRAÇÕES}

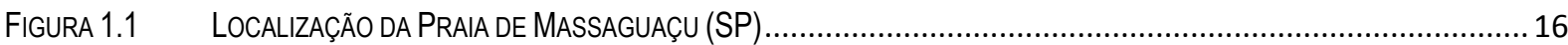

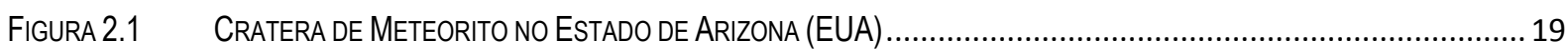

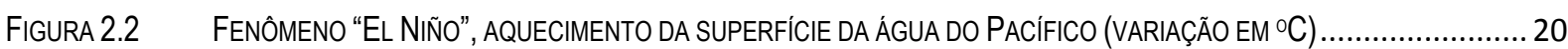

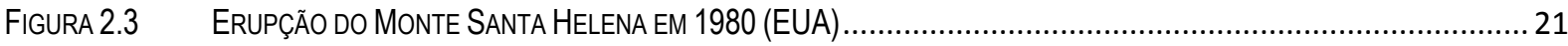

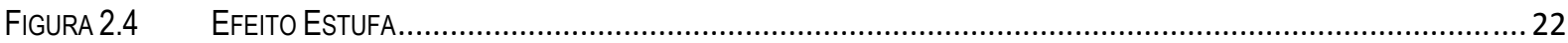

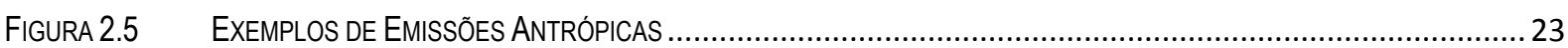

FIGURA 2.6 ILUSTRAÇÃo dE INTENSIFICAÇÃo dE FeNÔMENOS CLIMÁTICOS DEVIDO AO AQUECIMENTO GLOBAL ......................23

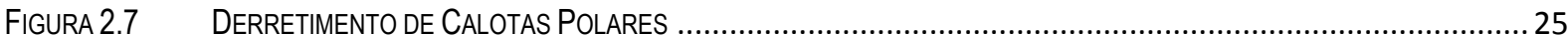

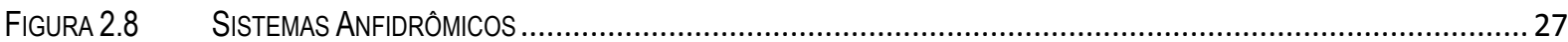

FIGURA 2.9 ELEVAÇÃO DO NIVEL DO MAR SOBRE AS EXTENSÕES DE TERRAS ÚMIDAS ................................................. 28

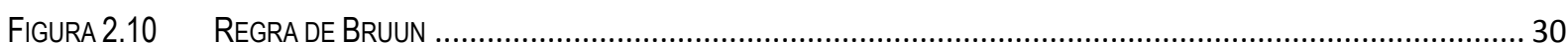

FIGURA 2.11 VISTA DO MODELO FÍSICO (LABORATÓRIO DE HIDRÁULICA DA EPUSP) ……............................................. 31

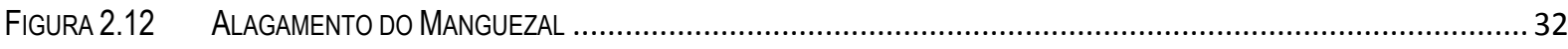

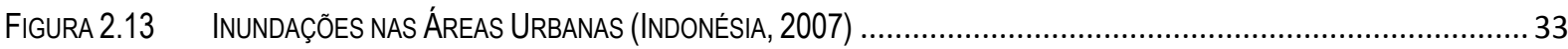

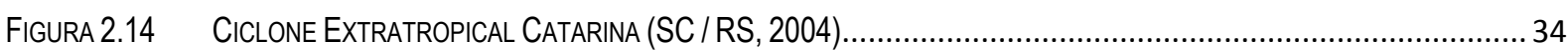

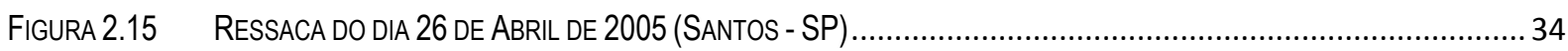

FIGURA 2.16 PaREDão na PRAIA de MILIONÁRIOS (SÃo VICENTE / SP) ................................................................ 38

Figura 2.17 Mureta de Alto da Praia em Mongaguá / SP (Praia Central) ............................................................ 39

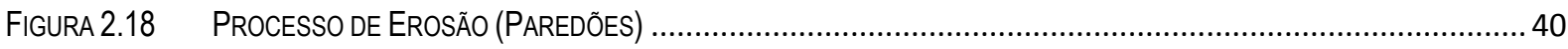

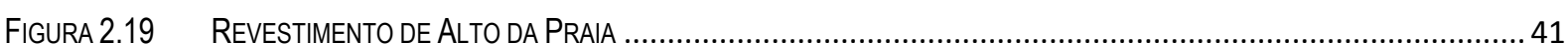

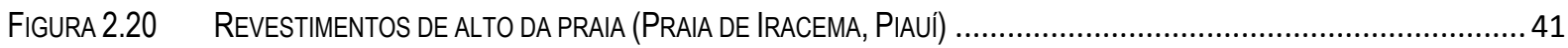

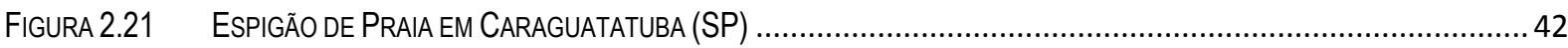

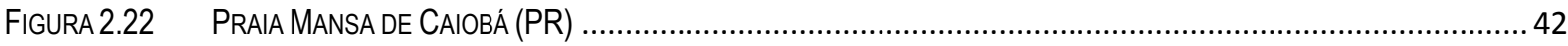

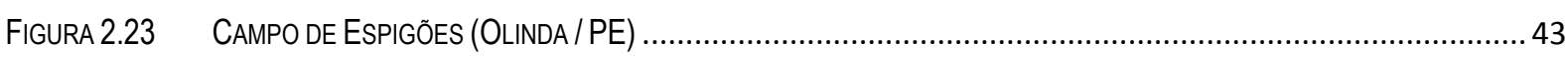

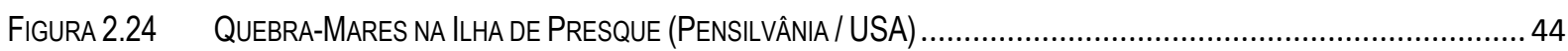

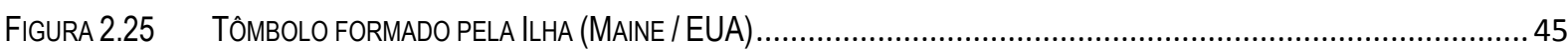

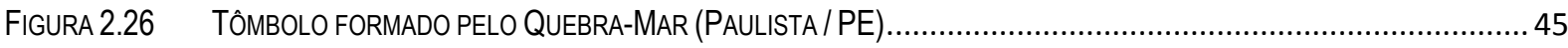

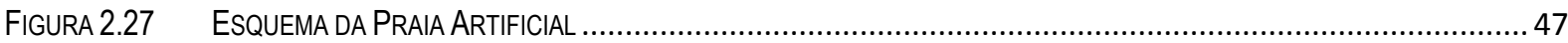

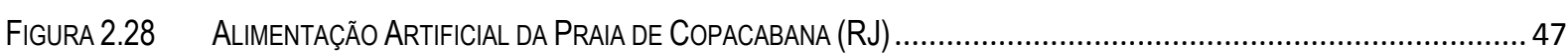

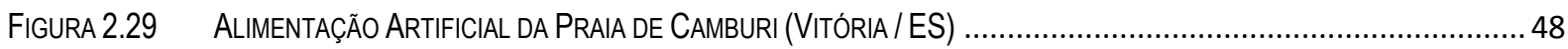

FIGURA 2.30 DIQUE SEPARANDO O MAR DO NORTE DO LAGO DE IJSSELmEER (HolandA).................................................. 49

FIGURA 2.31 ESQUEMA DA TÉCNICA DE FIXAÇÃO DE DUNAS (AQUITANIA / FRANÇA)....................................................... 50

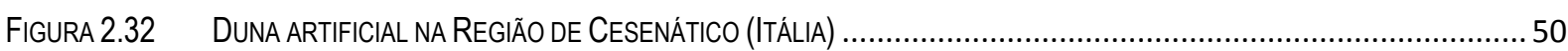

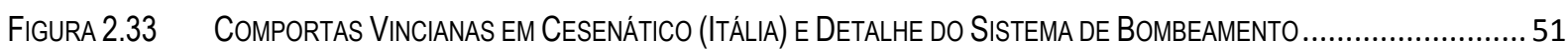




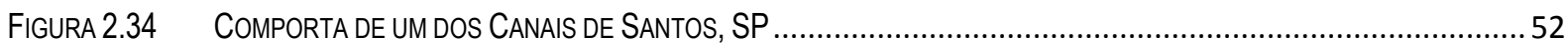

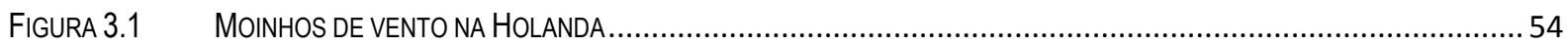

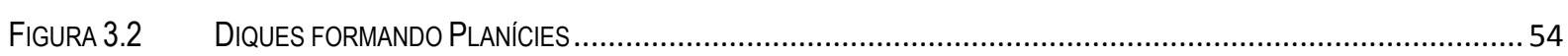

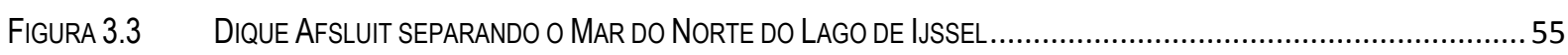

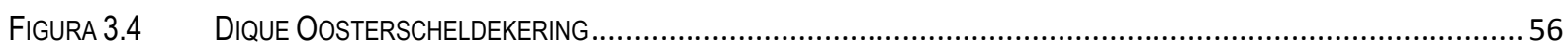

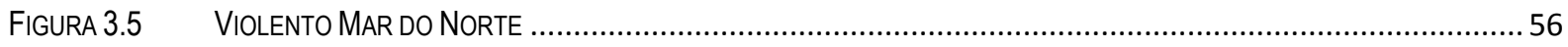

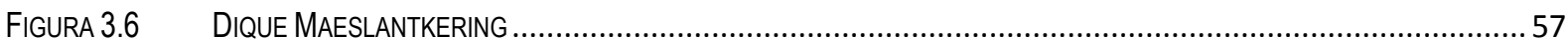

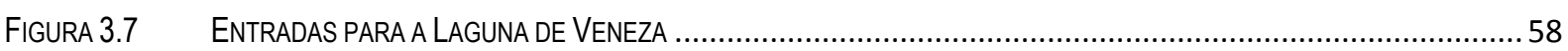

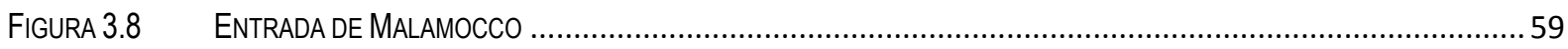

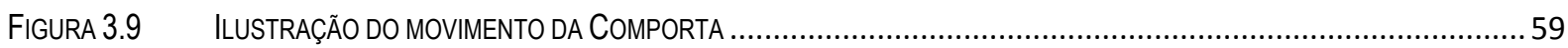

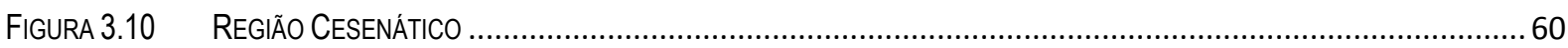

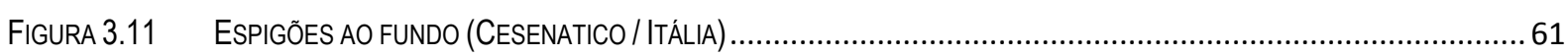

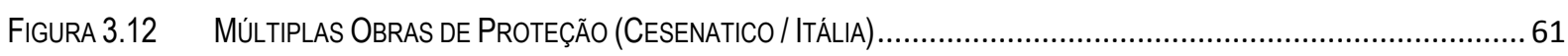

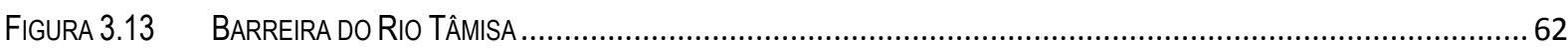

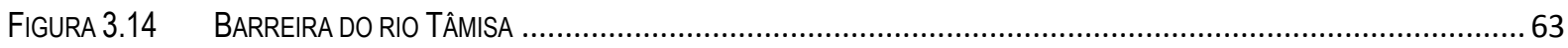

FIGURA 3.15 ILUSTRAÇÃO DO FUNCIONAMENTO DA COMPORTA NO RIO TÂMISA ......................................................... 64

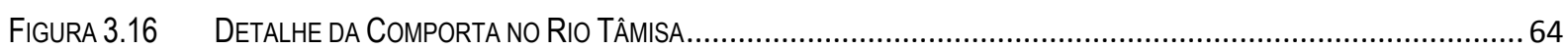

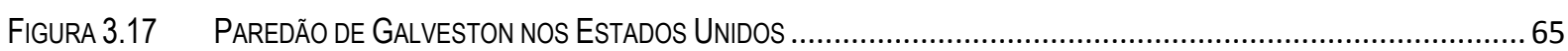

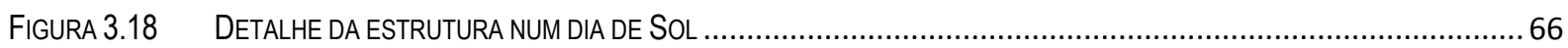

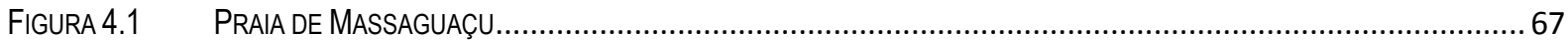

FIGURA 4.2 VISTA GERAL DO TRECHO AfETADO

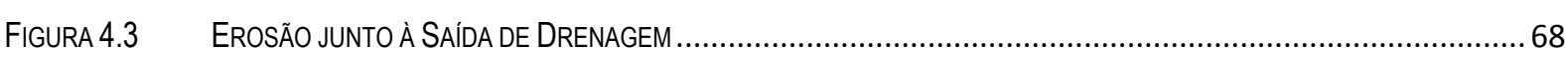

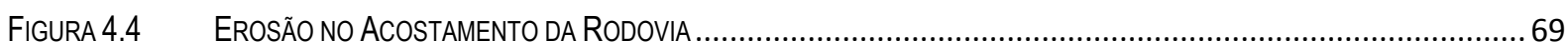

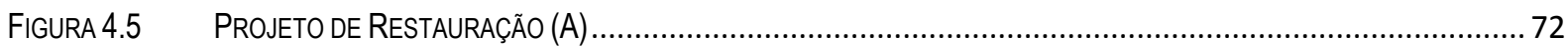

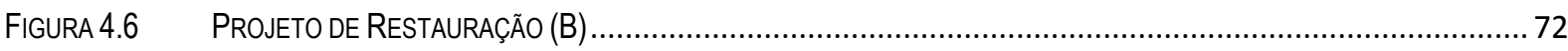

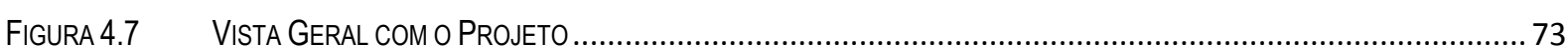

FIGURA 4.8 HISTÓRICO FOTOGRÁFICO DA EXECUÇÃO DO MURO DE PEDRA ARGAMASSADA ............................................... 76

FIGURA 4.9 SOLAPAMENTO DE 160 METROS DE MURO DE CONTENÇÃO (2006) ........................................................... 76

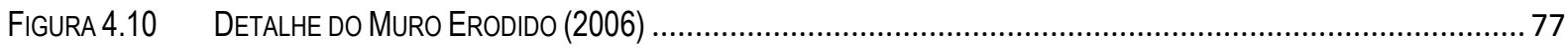

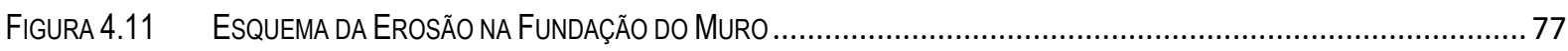

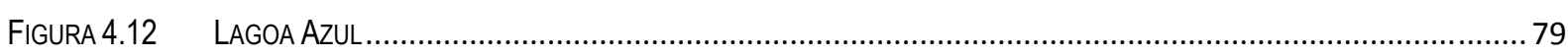

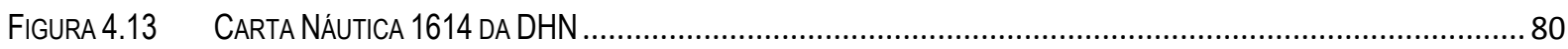

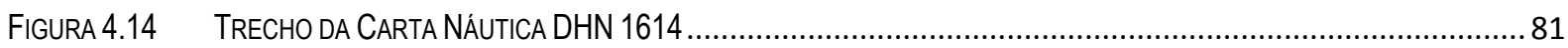

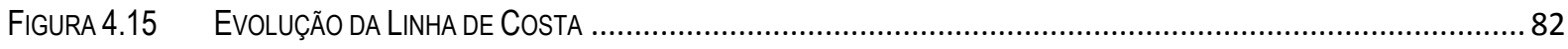

FIGURA 4.16 ROSA DE TRANSPORTE DE SEDIMENTOS LITORÂNEO LONGITUDINAL............................................................... 82

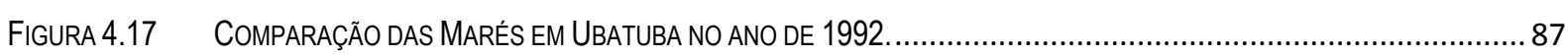

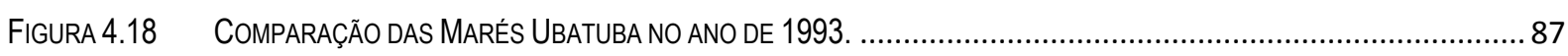

FIGURA 4.19 IMAGEM DE SATÉLITE DA SITUAÇÃO METEOROLÓGICA NO DIA 06 DE JUNHO DE 2006 ...................................... 88 
FIGURA 4.20 SUBQUADRADOS DO QUADRADO 376 DE MARSDEN PARA A CoSTA DE São PAULO ..................................... 93

FIGURA 4.21 RUMOS COM NV (NORTE VERDADEIRO) DA AGITAÇÃO NO SUBQUADRADO MARSDEN 37634 .........................94

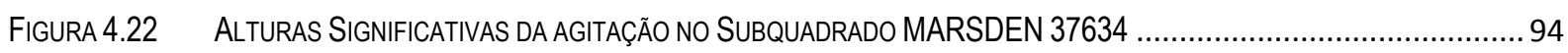

FIGURA 4.23 RUMOS COM NV (NORTE VERDADEIRO) DA AGITAÇÃO NO SUBQUADRADO MARSDEN 37644 .......................... 95

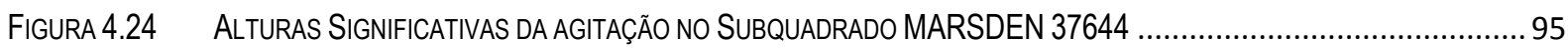

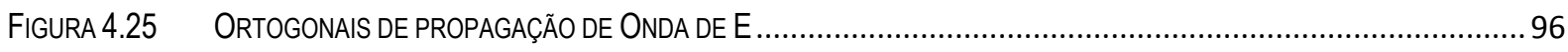

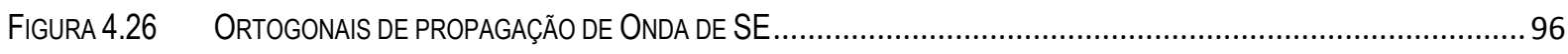

FIGURA 4.27 ROSA DE ONDAS - ALTURA SIGNIFICATIVA (M) MÉDIA ANUAL_.................................................................. 97

FIGURA 4.28 ALTURA SIGNIFICATIVA PARA ONDA EM ÁGUAS PROFUNDAS COM RUMO DE 101,57\%, ALTURA SIGNIFICATIVA DE 1,38 M

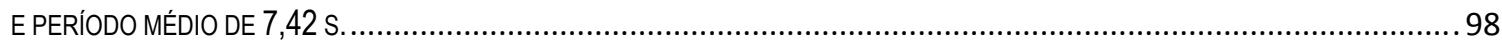

FIGURA 4.29 ALTURA SIGNIFICATIVA PARA ONDA EM ÁGUAS PROFUNDAS COM RUMO DE 125, $9^{\circ}$, ALTURA SIGNIFICATIVA DE 1,22 M

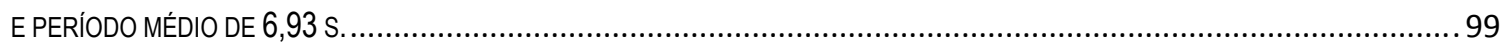

FIGURA 4.30 MODELO DE PREVISÃo DE ALTURA DE ONDA PARA A SITUAÇÃ̃ CLIMÁTICA .................................................. 100

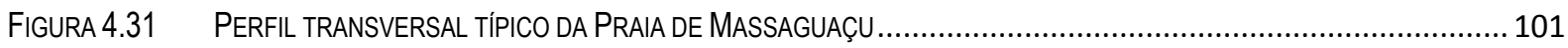

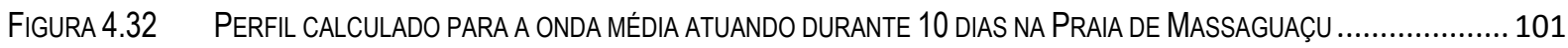

FIGURA 4.33 DIAGRAMA ESQUEMÁTICO DO ATAQUE DE ONDA DE TEMPESTADE NA PRAIA E PÓS-PRAIA .............................. 103

FIGURA 4.34 DEFINIÇÃO DE ESPRAIAMENTO, MEDIDO A PARTIR DO NIVELL DO MAR ….................................................... 104

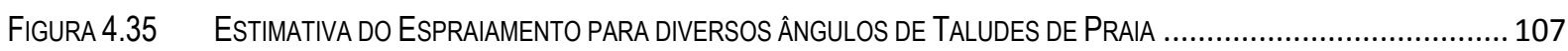

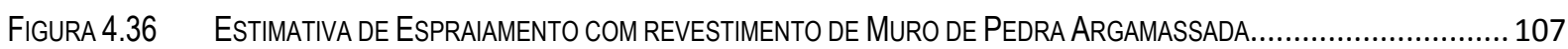

FIGURA 4.37 EstimATIVA DE ESPRAIAMENTO COM REVESTIMENTO DE ENROCAMENTO ................................................ 108

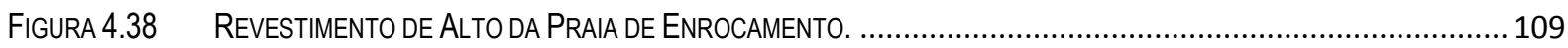

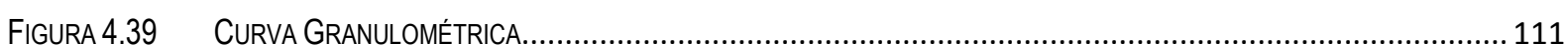

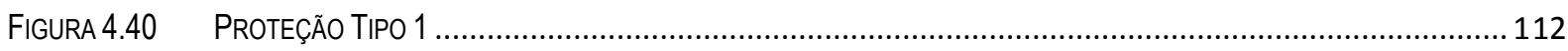

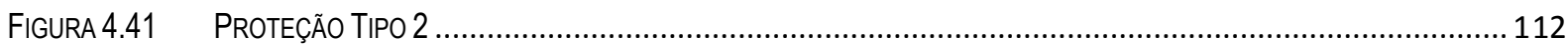

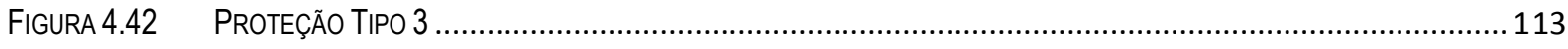

FIGURA 4.43 PROXIMIDADE DO MAR À SP-55 (ILUSTRAÇÃO SEM ESCALA) ….............................................................. 113

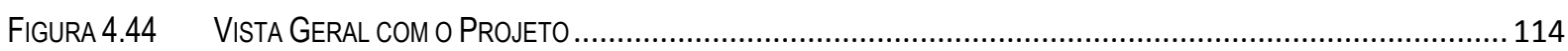

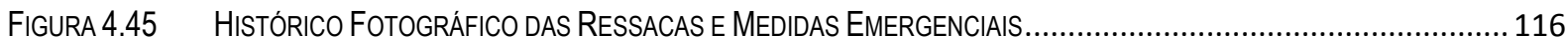

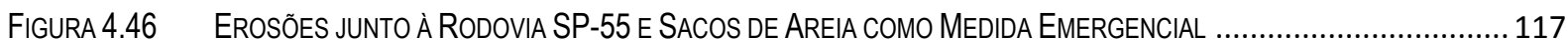

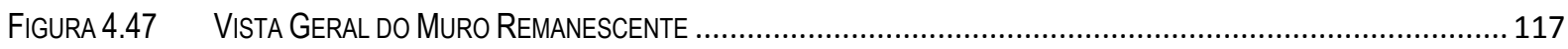

FIGURA 4.48 DETALHE DO BARBACÃ NO MURO E DO EXTREMO LONGITUDINAL DA OBRA ............................................. 118 


\section{LISTA DE TABELAS}

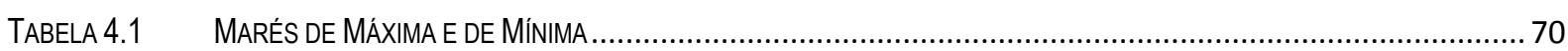

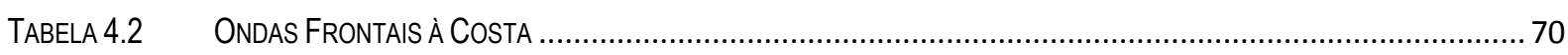

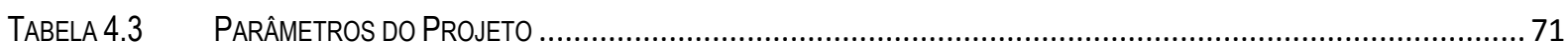

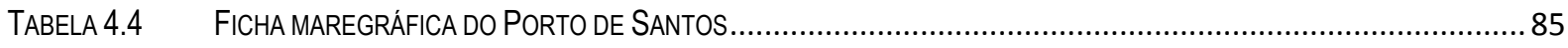

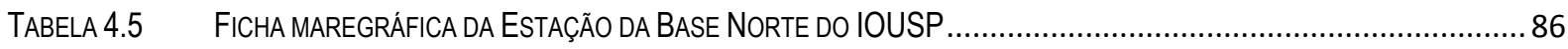

TABELA 4.6 PREVISÃO DA MARÉ ASTRONÔMICA PARA O PORTO DE SANTOS ................................................................. 89

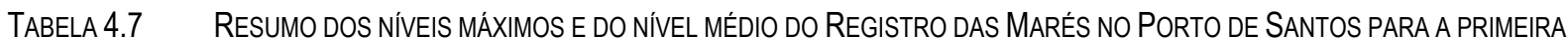

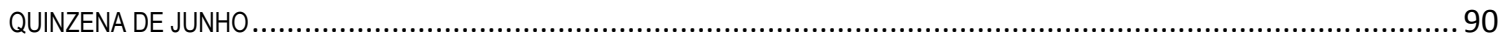

Tabela 4.8 Probabilidade da Altura da Onda Significativa IgUalar ou eXCEDer a Onda de Projeto duRANTE a VIDA

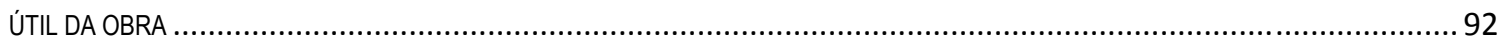

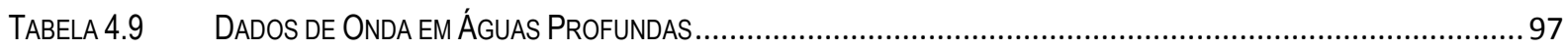




\section{SUMÁRIO}

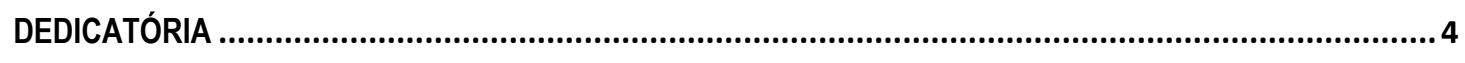

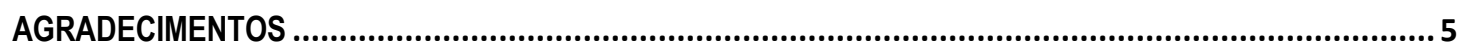

RESUMO

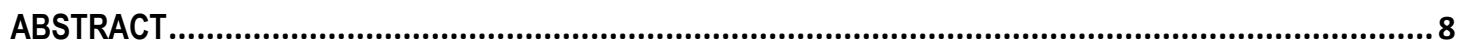

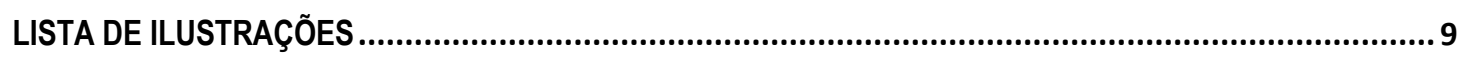

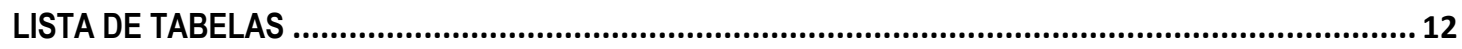

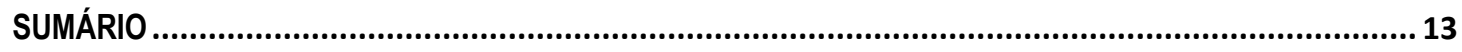

CAPÍTULO 1 INTRODUÇÃO …......................................................................................... 15

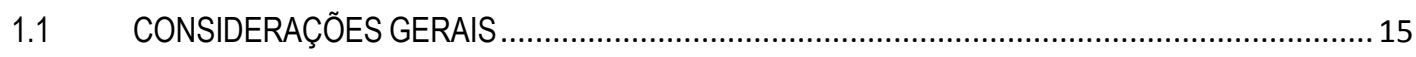

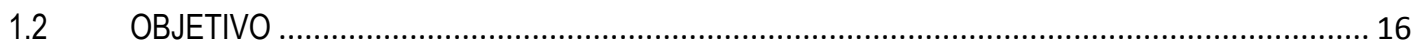

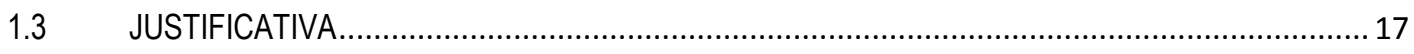

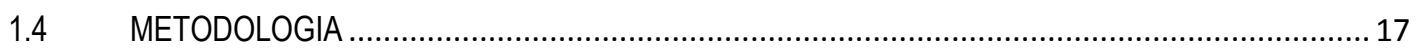

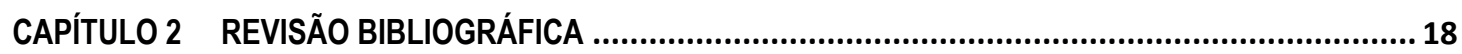

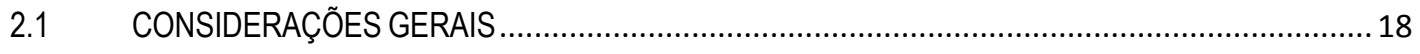

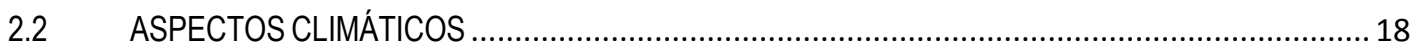

2.2.1 Mudanças Climáticas............................................................................................ 18

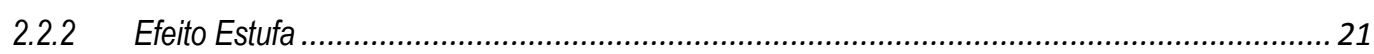

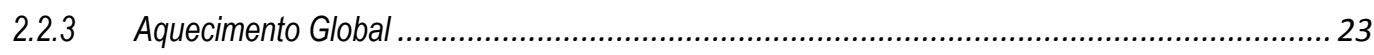

2.2.4 Elevação do Nivel Médio do Mar............................................................................ 26

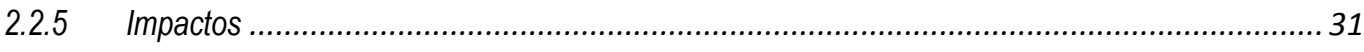

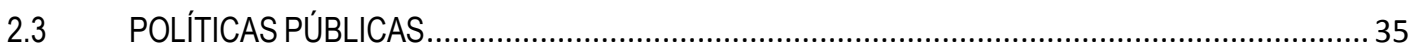

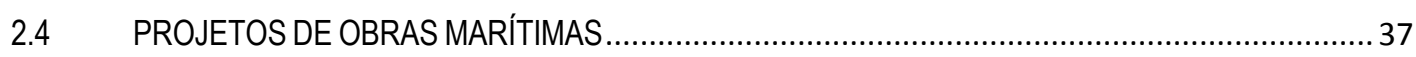

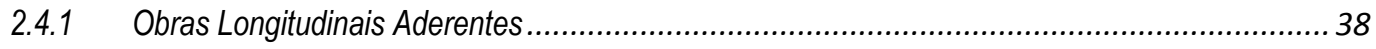

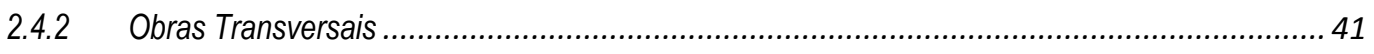

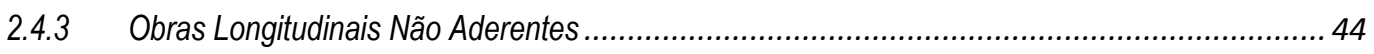

2.4.4 Alimentação Artificial de Praias............................................................................... 46

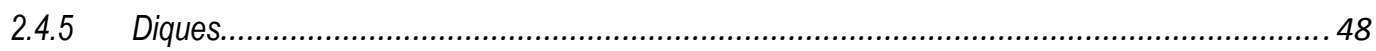

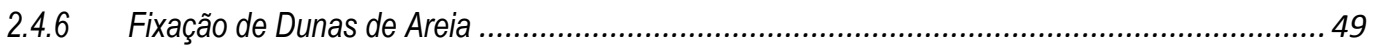

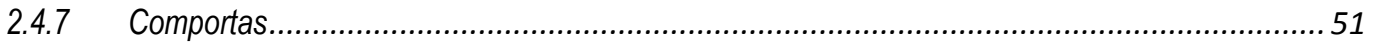

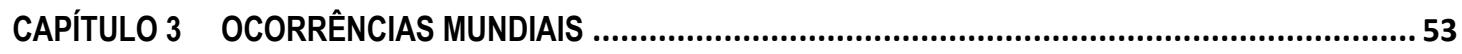

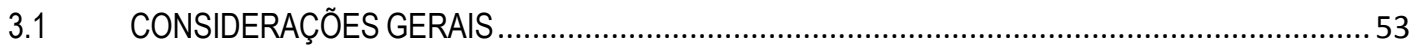




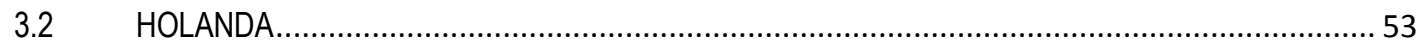

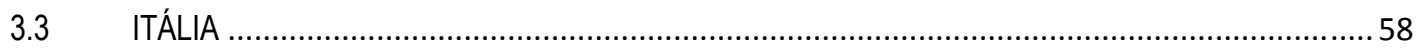

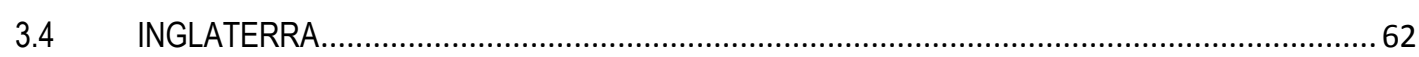

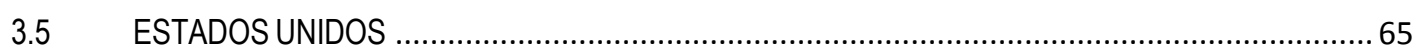

CAPÍTULO 4 ESTUDO DE CASO PRAIA DE MASSAGUAÇU............................................................67

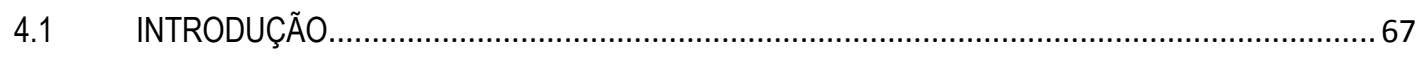

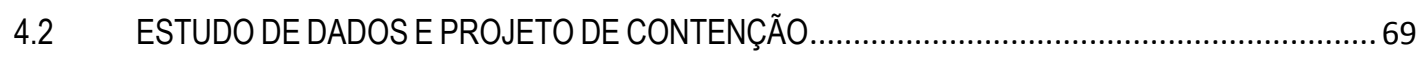

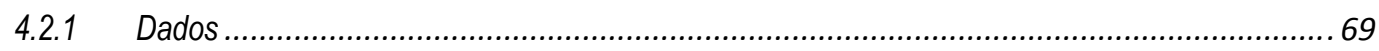

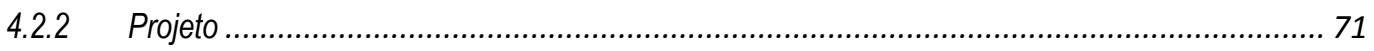

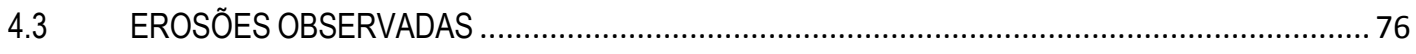

4.4 ESTUDO DE DADOS E PROJETO DE RECONSTRUÇÃO ......................................................... 78

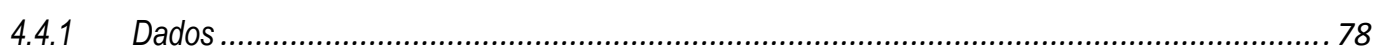

4.4.1.1 Morfodinâmica Praial ....……………………………………………………………….....79

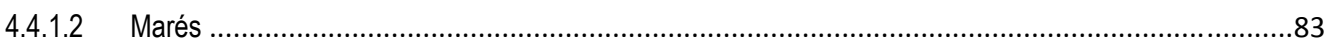

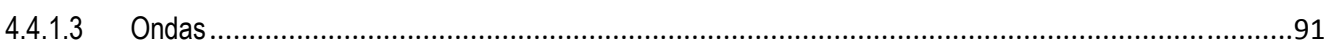

4.4.2 Verificação - Espraiamento.................................................................................. 102

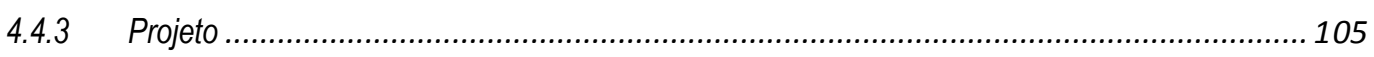

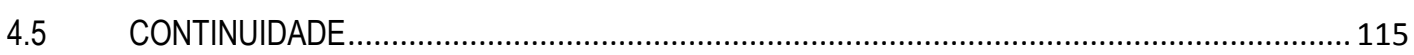

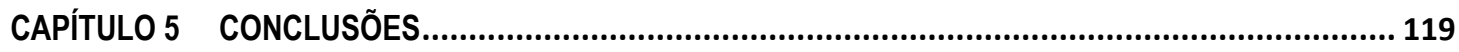

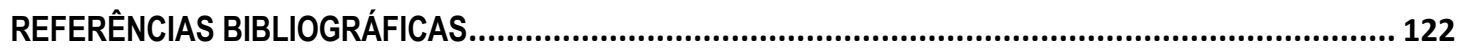




\section{CAPÍTULO 1 INTRODUÇÃO}

\subsection{CONSIDERAÇÕES GERAIS}

O aquecimento global e conseqüente elevação do nível médio do mar constituem-se num desafio para a manutenção e o projeto das estruturas marítimas nas próximas décadas. Tanto as mudanças climáticas globais, quanto o fato das tempestades extremas estarem sofrendo graves alterações, têm profundas conseqüências para a sociedade, bem como para o meio ambiente. Vários estudos e dados maregráficos de confiabilidade registrados na costa brasileira desde o ano de 1940 atestam esta realidade.

O litoral paulista tem cerca de $400 \mathrm{~km}$ de extensão e foi, desde os primórdios de sua história, um dos locais mais amplamente explorados e ocupados do Estado. $O$ século $X X$ trouxe grandes modificações para o litoral paulista. Desde as primeiras vilas até a ascensão da cidade de São Paulo, ocorreram melhorias como as verificadas na estrutura portuária de Santos e São Sebastião, e ainda a implantação do pólo petroquímico e industrial em Cubatão, e a construção de rodovias como Anchieta, Pedro Taques, Padre Manoel da Nóbrega (década de 50), Imigrantes, Tamoios e Rio - Santos (década de 70).

Esse crescimento atraiu imigrantes e turistas, proporcionando um crescimento urbano irregular e desordenado, causando fortes impactos ambientais nestas localidades. Aterros em manguezais, retificações em rios, rebaixamento do lençol freático e extração das areias de praias e dunas trouxeram grandes alterações no balanço sedimentar da costa paulista, que é composta, principalmente, por praias arenosas.

A Praia de Massaguaçu, Caraguatatuba - São Paulo, por exemplo, mantevese estável em relação aos processos erosivos até 1994. Porém, de uns anos para cá (especialmente no ano de 2005), houve uma significativa perda de areia da faixa 
praial por processos ainda não totalmente conhecidos. Estudos das possíveis causas e soluções desse caso específico serão discutidos nos capítulos posteriores, uma vez que essa será a região do presente estudo.

\subsection{OBJETIVO}

O trabalho tem como objetivo inicial apresentar e discutir os múltiplos aspectos pelos quais as mudanças climáticas em curso afetam os projetos das obras marítimas. A partir desses aspectos, o objetivo principal é analisar os paradigmas para os projetos de obras marítimas, como as defesas costeiras e obras de estabilização para manter ou reconstruir os sistemas naturais (falésias, dunas, terras úmidas, praias), ou para proteger as construções e infra-estruturas costeiras (áreas urbanas, acessos de ligação, rodovias).

Para essa análise, será estudado um caso situado na Rodovia Dr. Manuel Hyppolito Rego - SP-55, na Praia de Massaguaçu, cidade de Caraguatatuba (SP). Nesse local existe uma instabilidade de talude do aterro, devido a erosões causadas pelas ondas do mar, agravadas pelas saídas de drenagem superficiais da rodovia.

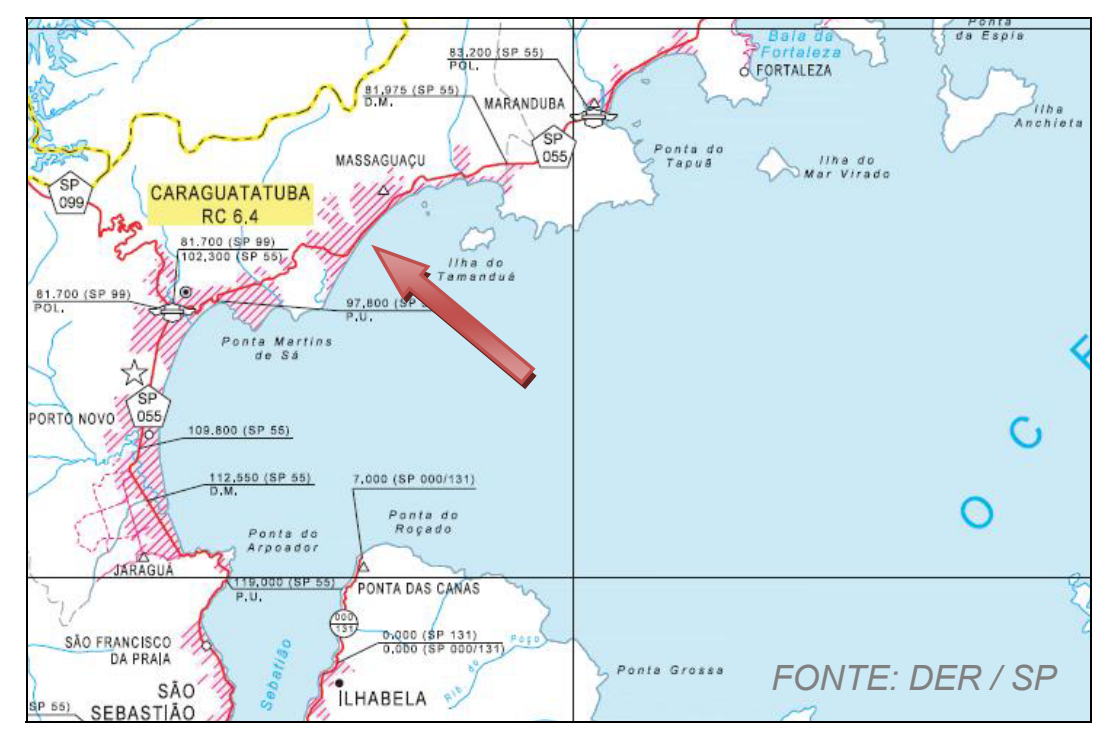

Figura 1.1 Localização da Praia de Massaguaçu (SP)

As principais preocupações neste sentido referem-se à redução dos danos pela intensificação das marés meteorológicas e tempestades, que causam 
inundações e danos pelas ondas, mitigação da erosão costeira e a proteção e recuperação dos ecossistemas.

\subsection{JUSTIFICATIVA}

O controle completo do enfrentamento dos efeitos das mudanças climáticas constitui-se num mito, cujo conceito deve ser desencorajado, pois estabelece uma falsa sensação de segurança para a sociedade, uma vez que não é possível controlar a natureza, já que há sempre a probabilidade de um evento mais energético impactar a obra marítima, que deve ser projetada a partir de paradigmas de mitigar os danos advindos, e principalmente, os danos já ocorridos.

As diferenças existentes entre os princípios de funcionamento das diversas soluções de obras costeiras de defesa dos litorais e as conseqüentes solicitações sobre elas exercidas pelo meio físico em mutação motivaram a decisão quanto à escolha do tema desta dissertação. Isto é, o estudo dos projetos de obras marítimas com o objetivo de minimizar os impactos sobre as linhas de costa atuais, nas áreas mais vulneráveis aos efeitos das mudanças climáticas na costa brasileira.

\subsection{METODOLOGIA}

Com base na revisão bibliográfica sobre os projetos de engenharia como paradigmas para o enfrentamento dos efeitos das mudanças climáticas, analisou-se a ocorrência de erosão costeira na Praia de Massaguaçu, litoral norte do Estado de São Paulo. Neste estudo, foram avaliados os projetos e obras realizados para a contenção dessa erosão local, considerando as recomendações das políticas públicas existentes em nível internacional. Dessa forma, todos esses subsídios foram considerados, apresentando as possíveis soluções para o problema de erosão ocorrido em uma região costeira, face à iminente elevação relativa do nível médio do mar. 


\section{CAPÍTULO 2 REVISÃO BIBLIOGRÁFICA}

\subsection{CONSIDERAÇÕES GERAIS}

O presente capítulo apresenta uma síntese dos principais conceitos teóricos necessários para o bom desenvolvimento do trabalho. Foi feita uma revisão bibliográfica dos fundamentais aspectos climáticos, analisando as mudanças climáticas, efeito estufa, aquecimento global, elevação do nível do mar e seus impactos. Também são apresentados conceitualmente as políticas públicas e os projetos de obras marítimas.

\subsection{ASPECTOS CLIMÁtICOS}

\subsubsection{Mudanças Climáticas}

O termo mudanças climáticas ou alterações climáticas refere-se à variação do clima global ou dos climas regionais da Terra ao longo do tempo. Estas variações dizem respeito a alterações de temperatura, precipitação, nebulosidade, ventos e outros fenômenos climáticos em relação às médias históricas.

Estas alterações climáticas podem ser causadas por dois tipos de processos: naturais, como, por exemplo, variações na intensidade da luz solar, ou antropogênicos, resultado da atividade humana.

O processo com causas naturais acontece quando o fenômeno da mudança climática ocorre baseado na natureza, sem atuação do homem, e pode ter influência externa ao planeta Terra, bem como influência de origem interna, terrestre. 
Dentre as causas naturais com origem externa ao globo terrestre temos o ciclo solar (radiação e campo magnético). A radiação, propriamente dita, aumenta cerca de $10 \%$ a cada bilhão de anos, ou seja, no início da vida na Terra, quase quatro bilhões de anos atrás, a energia do Sol era em torno de $70 \%$ da atual. O Ciclo Solar é a variação de intensidade do vento solar e do campo magnético solar causado pelo aumento da atividade geomagnética da Terra e da oscilação da temperatura do plasma ionosférico na estratosfera de nosso planeta.

Também é apontado como causa de mudança climática o fenômeno de variação orbital, ou seja, o aumento, ou diminuição, das radiações solares devido às variações no movimento da Terra em relação ao Sol.

Impactos de meteoritos são eventos raros, mas também podem modificar o clima na Terra. Impactos de grandes proporções podem modificar profundamente a biosfera (Figura 2.1). Com o impacto, detritos podem ser arremessados até o espaço e entrarem na órbita da Terra, onde ficariam por algum tempo e só depois cairiam. Assim, ocorreriam incêndios em escala global e a liberação de grandes quantidades de gás carbônico $\left(\mathrm{CO}_{2}\right)$ na atmosfera causando o efeito estufa.

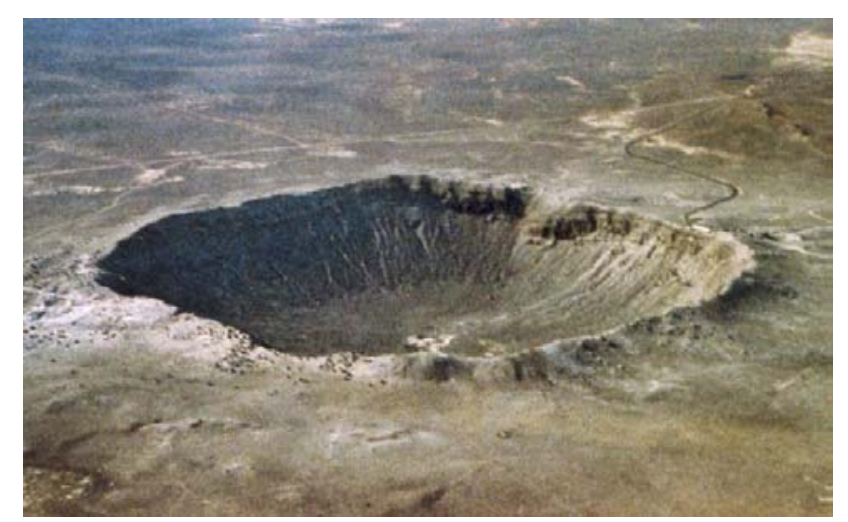

Figura 2.1 Cratera de Meteorito no Estado de Arizona (EUA) FONTE: pt.wikipedia.org/wiki/Ficheiro:Meteor.jpg

Como exemplo de causas naturais, com influência de origem interna, podemos citar as mudanças ou deriva dos continentes aproximando ou afastando-se dos pólos. A movimentação das placas tectônicas ocorre algo em torno de 2 centímetros por ano, o que poderia provocar um distúrbio na atmosfera.

Também modificam o clima de maneira natural, com origem terrestre, os fenômenos "El Niño", ilustrado na Figura 2.2, e "La Niña", que se caracterizam como mudança na temperatura da água do oceano Pacífico. A mudança de temperatura 
das águas influencia a intensidade dos ventos Alísios que pode fazer com que massas de água quente, e massas de ar também, se desloquem no Pacífico de forma diferente dos registros das médias históricas. As variações de intensidade dos ventos Alísios influenciam a pressão atmosférica no oceano, afetando vários fenômenos climáticos em todo o mundo.

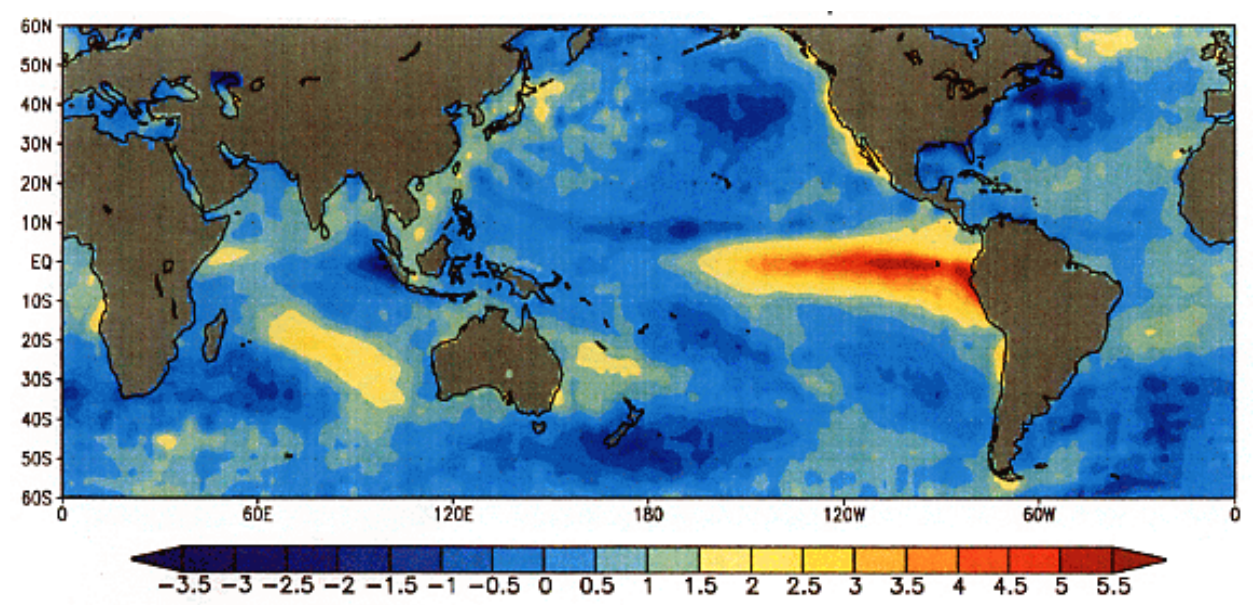

Figura 2.2 Fenômeno "El Niño", aquecimento da superfície da água do Pacífico (variação em ${ }^{\circ} \mathrm{C}$ ) FONTE: pt.wikipedia.org/wiki/Ficheiro:El-nino.gif

O esfriamento global é uma teoria que preconiza o resfriamento total da superfície terrestre dando início a uma nova era glacial, ou seja, uma nova glaciação, modificando o clima do planeta. As glaciações pretéritas provocaram grandes mudanças no relevo continental e no nível do mar. Quando a temperatura global diminui ocorre, como conseqüência, o aumento das geleiras, ou seja, as baixas temperaturas provocam o congelamento da água nos pólos aumentando a quantidade de gelo nas calotas polares, e rebaixando de maneira eustática o nível dos oceanos.

O vulcanismo também é considerado uma das causas naturais, de influência interna, das mudanças climáticas. A atmosfera carregada de pó vulcânico reteria a radiação terrestre, aumentando a temperatura na superfície da Terra (ver Figura 2.3). Entretanto, alguns estudiosos contestam essa hipótese. 


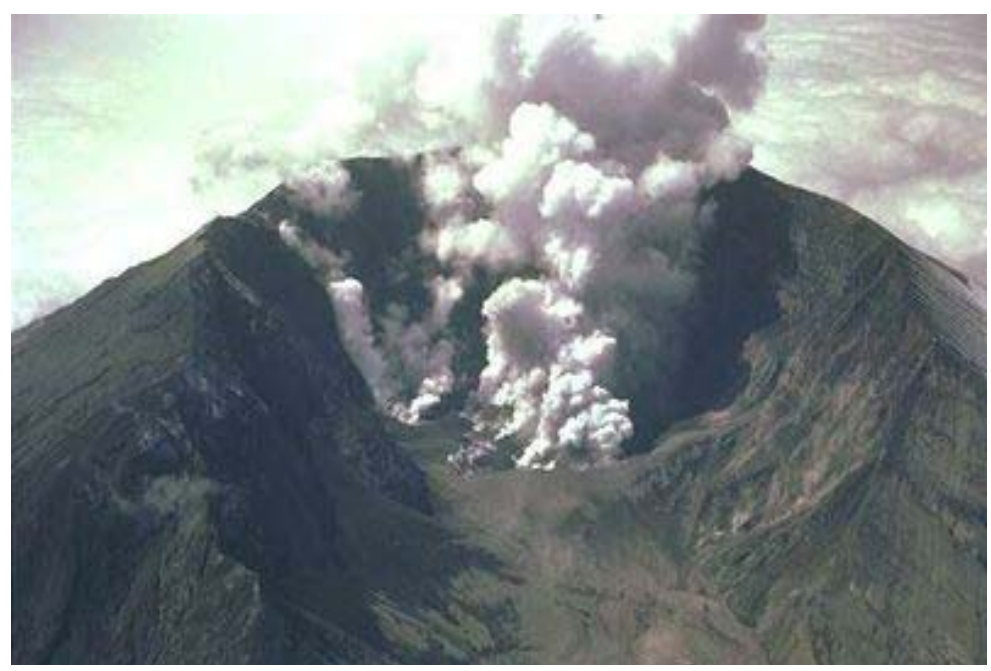

Figura 2.3 Erupção do Monte Santa Helena em 1980 (EUA) FONTE: pt.wikipedia.org/wiki/Ficheiro:Volcano.jpeg

Outro tipo de processo causador dessas alterações climáticas são os antropogênicos, como, por exemplo, o fenômeno do efeito estufa. Neste caso, há uma intensificação das mudanças climáticas, pois o calor retido, pelo vapor de água e pelos gases do efeito estufa em excesso, aumenta a temperatura do sistema.

\subsubsection{Efeito Estufa}

O efeito estufa é um processo que ocorre quando uma parte da radiação solar refletida pela superfície terrestre é absorvida por determinados gases, como o dióxido de carbono $\left(\mathrm{CO}_{2}\right)$, ozônio $\left(\mathrm{O}_{3}\right)$, metano $\left(\mathrm{CH}_{4}\right)$ e óxido nitroso $\left(\mathrm{N}_{2} \mathrm{O}\right)$, e também pelo vapor d'água $\left(\mathrm{H}_{2} \mathrm{O}\right)$, presentes na atmosfera. Como conseqüência disso, o calor fica retido, não sendo liberado ao espaço, como ilustrado na Figura 2.4 . 


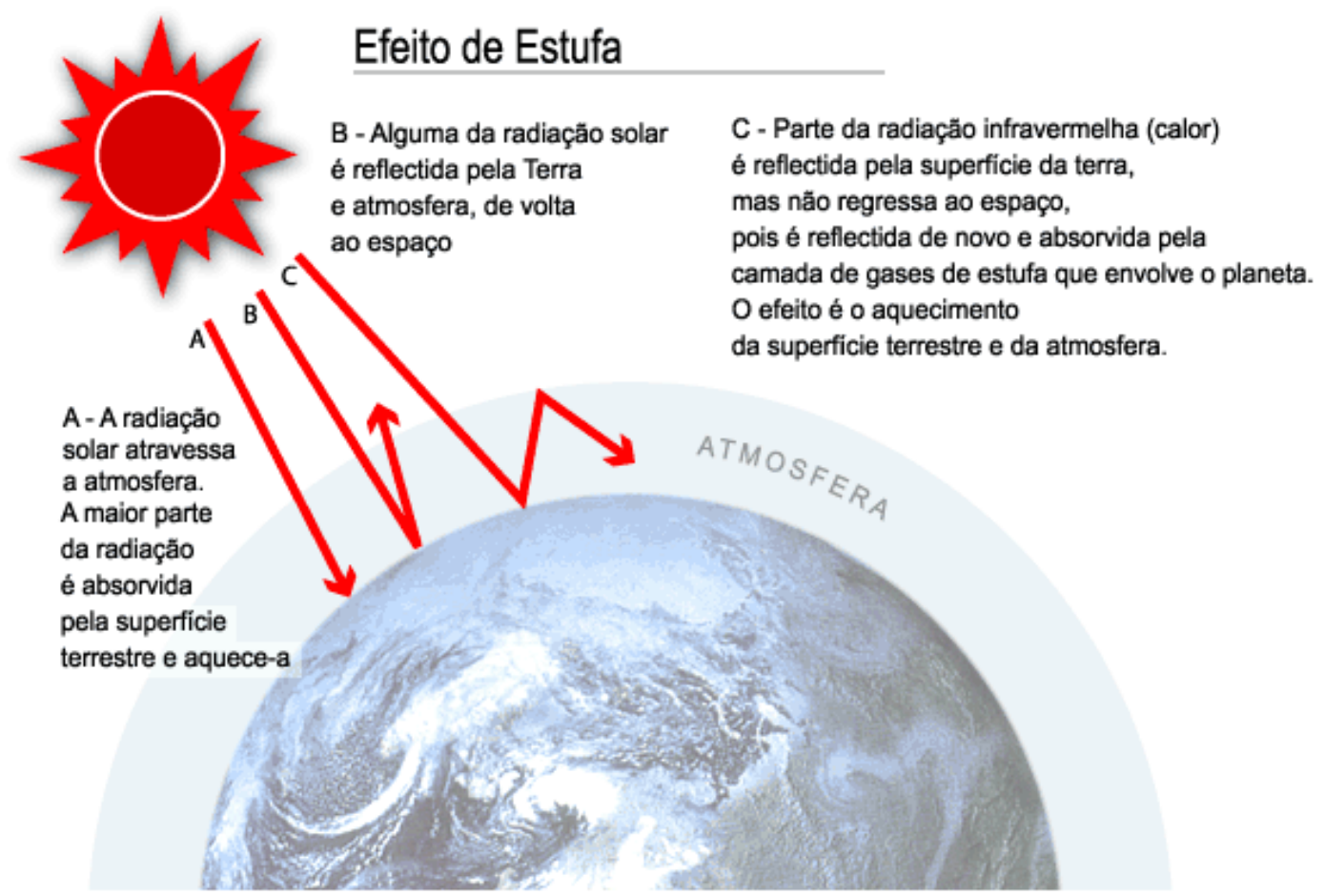

Figura 2.4 Efeito Estufa

FONTE: www.rudzerhost.com/ambiente/estufa

O efeito estufa, embora seja prejudicial em excesso, é na verdade vital para a vida na Terra, pois é ele que mantém as condições ideais para a manutenção da vida, com temperaturas mais adequadas. Assim, pela ação do efeito estufa natural, a atmosfera se mantém cerca de $30^{\circ} \mathrm{C}$ mais aquecida, possibilitando, com isso, a existência de vida no planeta Terra, que sem o efeito estufa natural seria um simples deserto gelado. Um aquecimento de temperatura numa escala de tempo menor causa impactos muito mais desastrosos quando comparados a um resfriamento de temperatura em longo prazo.

Somando-se as atividades do homem, também denominadas antrópicas, a esse processo natural, resulta em contribuições adicionais de gases de efeito estufa, acentuando a concentração. O aumento nas concentrações de gases de efeito estufa tende a reduzir a eficiência com que a Terra se resfria.

As emissões antrópicas de $\mathrm{CO}_{2}$, gás que mais contribui para a intensificação do efeito estufa, decorrem principalmente da queima de combustíveis fósseis (carvão, petróleo e gás natural), em usinas termoelétricas e indústrias, veículos em circulação e sistemas domésticos de aquecimento (Figura 2.5). 

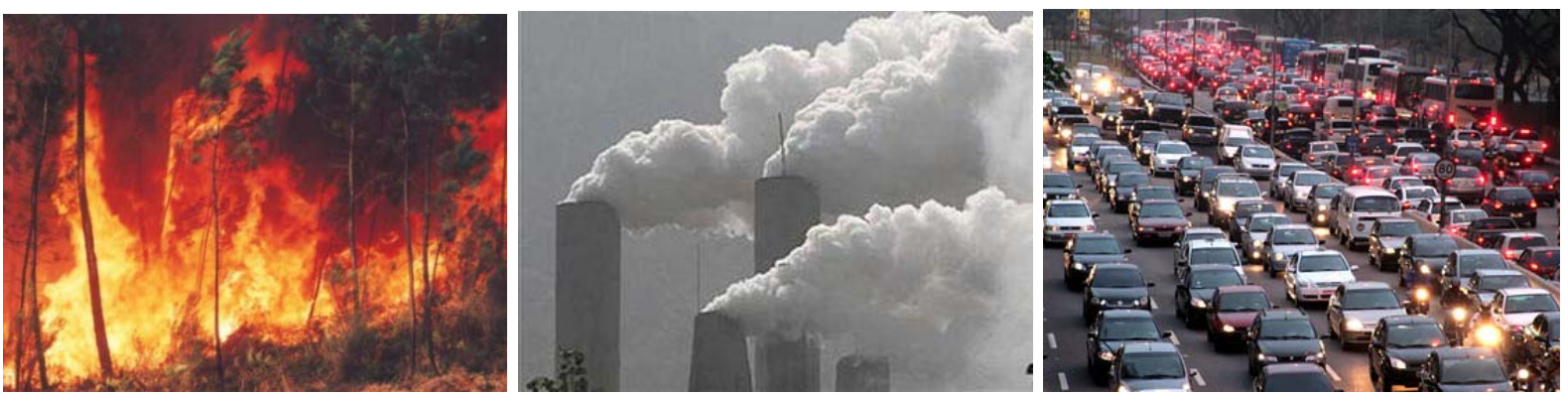

Figura 2.5 Exemplos de Emissões Antrópicas

FONTE: www.inclusaosocial.com, www.uol.com.br/folha/ciencia, www.atitudeverde.com.br

Esse excesso dos gases responsáveis pelo Efeito Estufa é o que desencadeia o fenômeno conhecido como Aquecimento Global, que é o grande problema na atualidade.

\subsubsection{Aquecimento Global}

Aquecimento global é um exemplo específico de mudança climática numa escala global. Fenômeno de aumento de temperatura desencadeado pelo excesso dos gases do efeito estufa, que, no uso comum, se refere ao aquecimento ocorrido nas últimas décadas e subentende-se uma influência humana (ilustrado na Figura 2.6).

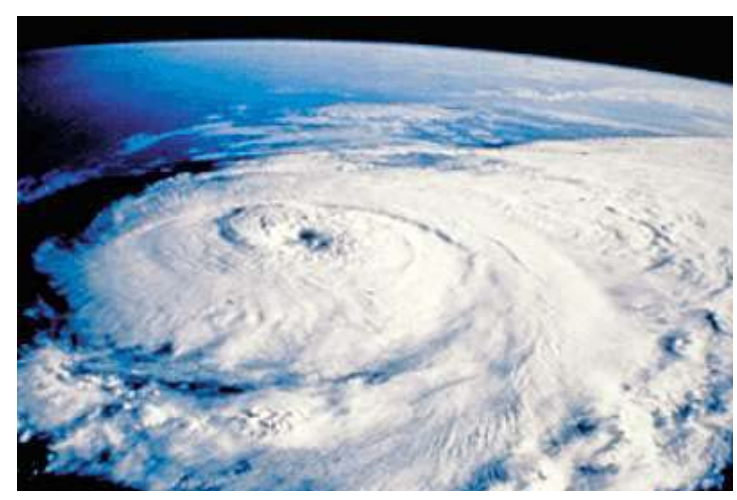

Figura 2.6 Ilustração de Intensificação de Fenômenos Climáticos devido ao Aquecimento Global FONTE: ecourbana.files.wordpress.com/2008/09/aquecimento_global.jpg

Buscando respostas científicas seguras e informações técnicas, sociais e econômicas relevantes para o entendimento das mudanças climáticas, foi estabelecido O Painel Intergovernamental sobre Mudanças Climáticas (IPCC- 
Intergovernmental Panel on Climate Change), em 1988, pelo Programa das Nações Unidas para o Meio Ambiente (PNUMA) e pela Organização Meteorológica Mundial (OMM).

O IPCC - Painel Intergovernamental sobre Mudanças Climáticas - no seu relatório mais recente diz que grande parte do aquecimento observado durante os últimos 50 anos se deve, muito provavelmente, a um aumento do efeito estufa, causado pelo aumento nas concentrações de gases do efeito estufa (GEE) de origem antropogênica.

O IPCC (Painel Intergovernamental sobre Mudanças Climáticas) tem três grupos de trabalho e uma equipe especial sobre inventários nacionais de gases do efeito estufa (GEE):

- Grupo de Trabalho I: avalia os aspectos científicos do sistema climático e de mudança do clima;

- Grupo de Trabalho II: avalia a vulnerabilidade dos sistemas sócio-econômicos e naturais diante da mudança climática assim como as possibilidades de adaptação a elas;

- Grupo de Trabalho III: avalia as opções que permitiriam limitar as emissões de GEE.

Segundo o IPCC (2002), baseado em cenários que incluem emissões tanto dos gases de efeito estufa quanto dos aerossóis, os modelos projetam uma estimativa de aumento de temperatura média global secular entre $0,9^{\circ} \mathrm{C}$ e $3,5^{\circ} \mathrm{C}$. Projeta-se que até 2100 , a taxa média será de $2^{\circ} \mathrm{C}$, variação extremamente preocupante, tendo em vista não ter sido observada nos últimos dez mil anos.

Dentre os principais efeitos adversos da mudança climática previstos até 2100 e que irão se refletir numa crise política, social e econômica sem precedentes, além do aumento do nível do mar, será a alteração no suprimento de água doce, um maior número de ciclones, tempestades de chuva e de neve mais fortes e freqüentes e o conseqüente ressecamento e esgotamento dos solos férteis.

Outras conseqüências significativas podem ocorrer em muitos sistemas ecológicos e sócio-econômicos advindos de longos períodos de secas e de um provável aumento de pragas e doenças tropicais, não se afastando a possibilidade de se ter afetado o satisfatório fornecimento de alimentos e recursos hídricos, prejudicando imensamente a qualidade de vida e a saúde humana. 
Segundo o $4^{\circ}$ relatório do IPCC, os impactos das mudanças climáticas no Brasil são inúmeros e preocupantes. No nordeste do Brasil as áreas semi-áridas e áridas vão sofrer uma redução dos recursos hídricos por causa das mudanças climáticas. A vegetação semi-árida provavelmente será substituída por uma vegetação típica da região árida, e nas florestas tropicais é provável a ocorrência de extinção de espécies. A recarga estimada dos lençóis freáticos irá diminuir, e as chuvas irão aumentar no sudeste com impacto direto na agricultura e no aumento da freqüência e da intensidade das inundações nas grandes cidades como Rio de Janeiro e São Paulo.

No futuro, o nível do mar, a variabilidade climática e os desastres provocados pelas mudanças climáticas devem causar impactos nos mangues. Cerca de $38 \%$ a $45 \%$ das plantas do mangue correm risco de extinção se a temperatura aumentar em $1,7^{\circ} \mathrm{C}$ em relação aos níveis da era pré-industrial. Hoje, o planeta já está $0,7^{\circ} \mathrm{C}$ mais quente que naquela época. (PROBIO, 2005)

O aquecimento global causa, por exemplo, a expansão térmica da água dos oceanos, aumentando a elevação do nível do mar. Outro fator tão importante é o derretimento de calotas polares e camadas de gelo sobre as montanhas (ilustrado na Figura 2.7), que são muito mais afetados pelas mudanças climáticas do que as camadas de gelo da Groenlândia e Antártica. Estas, provavelmente, não vão contribuir significativamente para o aumento do nível do mar nas próximas décadas, por estarem em climas frios, com baixas taxas de precipitação e derretimento.

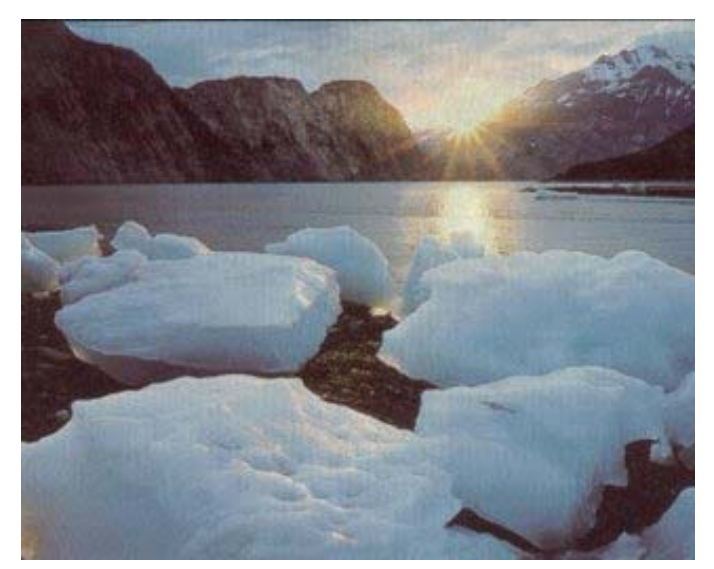

Figura 2.7 Derretimento de Calotas Polares FONTE: www.baixadao.net/imagens/Degelo2.jpg

Assim, segundo diagnóstico realizado pelo IPCC (2002), as atividades humanas têm causado a perda da biodiversidade (diversidade biológica), não 
apenas devido à contaminação e degradação dos solos, água e ar, mas também pelo aumento da temperatura média tanto na superfície terrestre quanto marinha. Sendo assim, os resultados esperados e observados dessas mudanças têm sido citados para as várias áreas do mundo, com influência significativa sobre os ecossistemas costeiros.

\subsubsection{Elevação do Nível Médio do Mar}

A subida relativa do nível do mar se deve à somatória de vários fatores como a subida eustática dos oceanos e a subsidência local.

A subida eustática do nível do mar corresponde a uma mudança global do nível d'água oceânico. Sua mais importante manifestação atual é a glácio-eustasia, produzida pelo derretimento das geleiras terrestres, e a expansão das águas oceânicas superficiais devido ao aquecimento global dos oceanos.

A subsidência local pode ser causada por vários motivos: alteamento da crosta terrestre devido a movimentos tectônicos; subsidência sísmica da superfície devido a bruscas e irregulares incidências de terremotos; auto-subsidência devido à compactação ou consolidação de camadas de subsolo moles de sedimentos, lama ou turfa; antropicamente induzida devido a cargas estruturais, bem como extração de água subterrânea e extração de óleo e gás; sempre buscando o equilíbrio isostático.

Variações devidas às flutuações climáticas e ao deslocamento dos pontos anfidrômicos (na Figura 2.8, sistemas anfidrômicos da componente M2 da maré dominante lunar), causado pela redução de atrito relativo da onda de maré devido à elevação global do nível do mar, também são fatores que se somam para a elevação do nível do mar. 


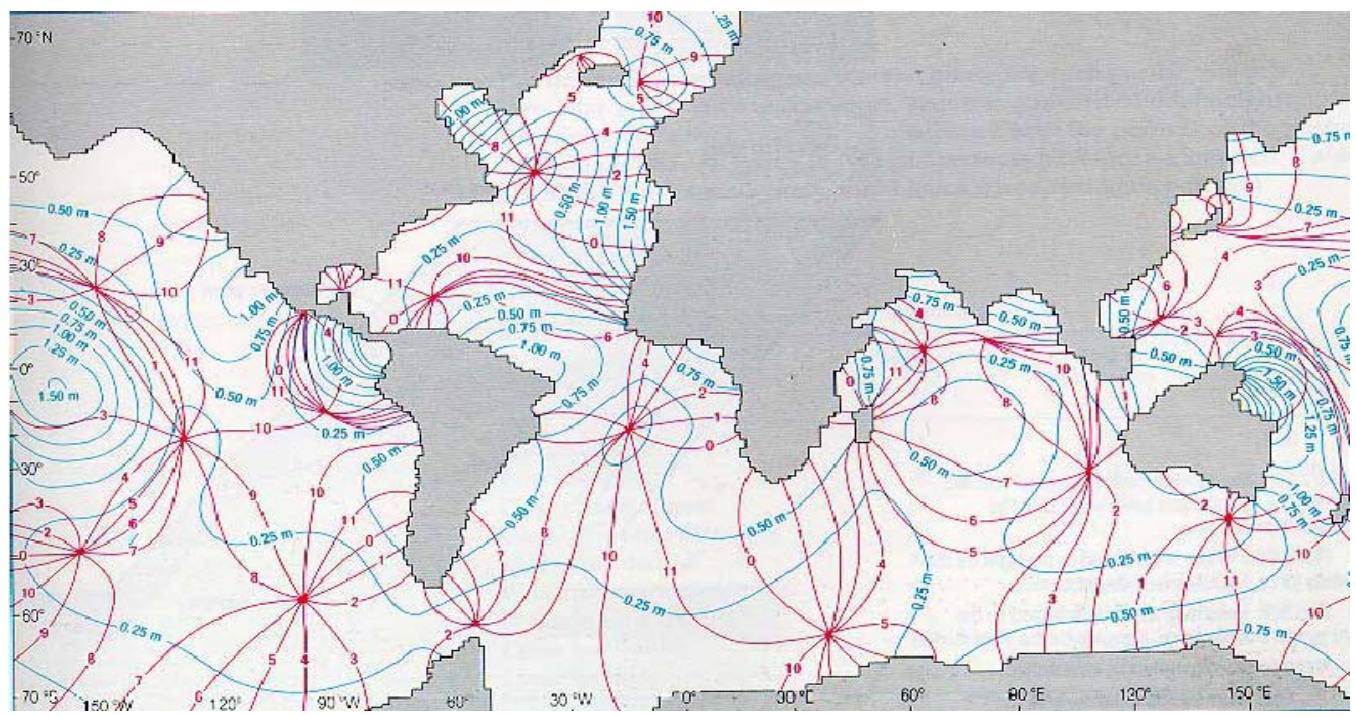

Figura 2.8 Sistemas Anfidrômicos

FONTE: Dean \& Dalrymple, 1984

As correntes não caminham em linha reta ao longo de um gradiente de pressão, mas são defletidas ou desviadas devido à rotação da Terra. O desvio de algo que se move na superfície do planeta é causado pela força de Coriolis, descrito inicialmente em 1835, pelo físico francês Gaspar de Coriolis.

O efeito Coriolis causa uma deflexão aparente nas correntes de maré, que no Hemisfério Norte ocorre para a direita, ou horária, e no Hemisfério Sul, anti-horária. Esses movimentos rotacionais associados à influência da geometria das bacias oceânicas imprimem um caráter rotatório das ondas de maré em oceano aberto, dando origem aos Sistemas Anfidrômicos (Figura 2.8). A propagação das marés ocorre em torno do ponto anfidrômico, no qual não existe variação de maré. As curvas concêntricas a esse ponto representam as linhas de mesma altura, enquanto as curvas radiais representam as linhas de mesma fase. A altura das marés em mar aberto é pequena, com variações inferiores a $50 \mathrm{~cm}$, entretanto, tende a aumentar conforme se afasta do ponto anfidrômico. Como os pontos anfidrômicos estão geralmente localizados no mar, as marés próximas à costa tendem a sempre serem maiores que aquelas no oceano (Dean \& Dalrymple, 1984).

O volume dos oceanos tem aumentado no decorrer do Século XX. Na costa do Estado de São Paulo, o Instituto Oceanográfico da USP tem estudos de longo período, mais de quarenta anos de registro, para a base sul do Instituto de Cananéia e para o Porto de Santos que indicam a subida do nível médio do mar com, respectivamente, taxas de 0,40 e 0,12 cm/ano (Harari, 1992-1993). 
Segundo os dados das Estações da Rede Maregráfica Permanente para a Geodésia (RMPG) do IBGE, no período compreendido entre dezembro de 2001 e dezembro de 2006, as elevações anuais médias no nível do mar foram de 2,5 mm em Imbituba (SC) e de $37 \mathrm{~mm}$ em Macaé (RJ). No primeiro caso, o aumento está dentro da média internacional divulgada recentemente pela Organização das Nações Unidas (ONU). No segundo, a forte elevação tem como causas as características geológicas locais, os efeitos sistemáticos do vento, e os efeitos hidrodinâmicos causados pelo crescimento acelerado na região, que estaria provocando alterações nos rios, diminuindo fluxos de água que são responsáveis pelo equilíbrio do sistema de avanço do mar sobre o litoral.

De acordo com a publicação do IPCC (2002), a América Latina, considerada como região com algumas das maiores concentrações de biodiversidade do planeta, vem apresentando a perda de cerca de $1 \%$ ao ano de mangues, diminuindo assim as terras úmidas, zonas de refúgio para peixes, crustáceos e moluscos, como ilustrado na Figura 2.9.
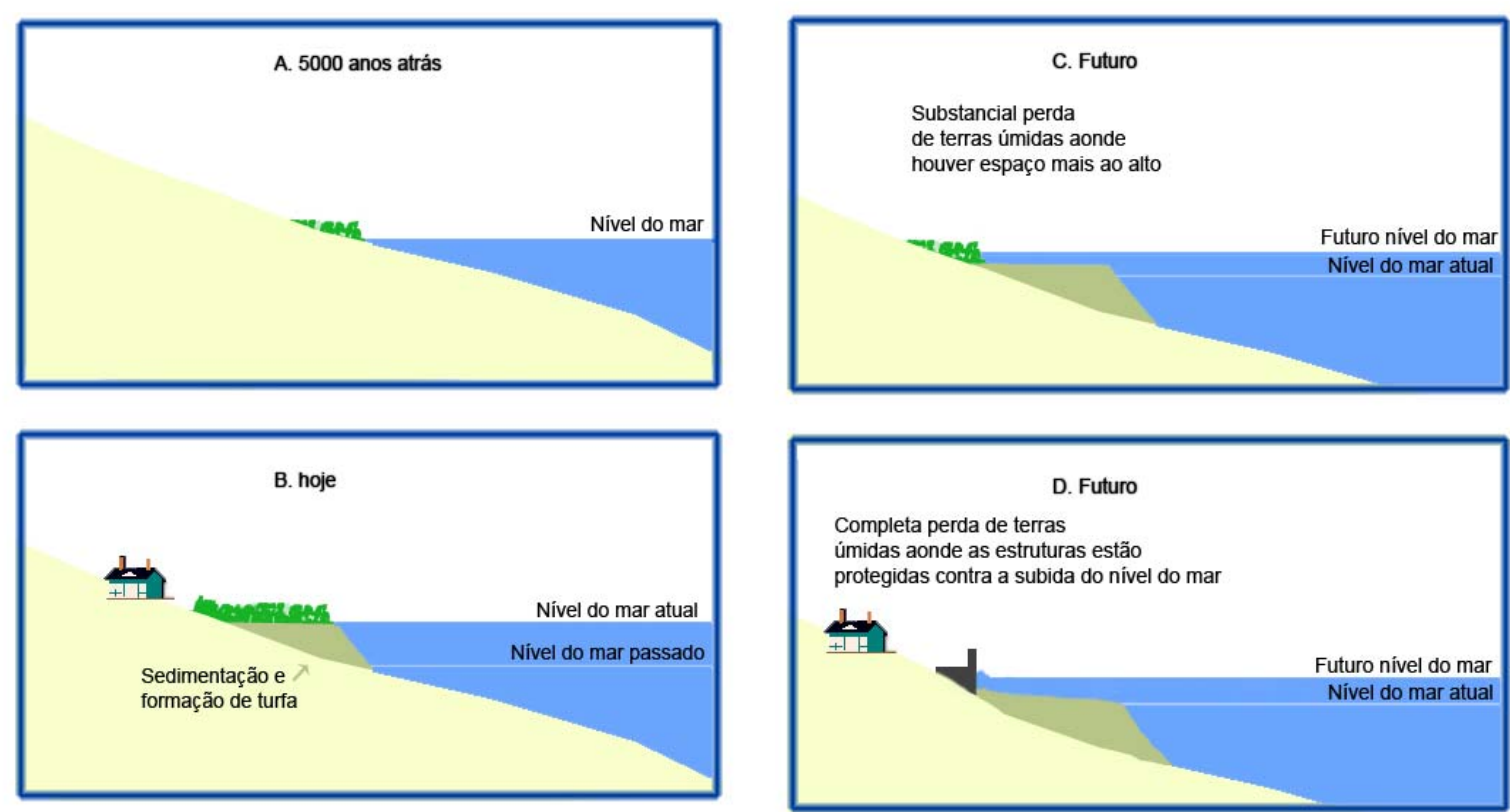

Figura 2.9 Elevação do nível do mar sobre as extensões de Terras Úmidas FONTE: Probio, 2005

Os pântanos em geral acompanharam o nível do mar através de sedimentação e formação de turfas. À medida que o nível do mar se elevou, novas terras úmidas foram formadas enquanto o limite para o mar se manteve. Portanto, se o nível do mar se eleva mais rapidamente do que a habilidade do pântano em 
acompanhar, haverá uma perda líquida das terras úmidas. Além disso, uma perda completa pode ocorrer se a proteção de áreas urbanizadas, com maciços ou diques, impedirem a formação de novas terras úmidas.

Se confirmadas as projeções para a mudança do clima global futuro, os impactos poderão ser potencialmente irreversíveis. Neste caso, os países insulares e as regiões urbanas costeiras são as mais vulneráveis com possibilidades reais de inundações a médio e longo prazo.

Os estudos do IPCC (2002) apontam para um aumento do nível do mar até 2100 de $49 \mathrm{~cm}$, também levando em conta as variações na estimativa dos parâmetros da sensibilidade climática, do derretimento do gelo e do conjunto completo dos cenários de emissões.

As evidências indicam que uma subida de $30 \mathrm{~cm}$ pode ocorrer até 2040, projetando-se de 50 a $200 \mathrm{~cm}$ até 2100 (VELLINGA \& ZITMAN, 1988).

O National Research Council's Board on Atmospheric Sciences and Climate (BASC) dos Estados Unidos e outros órgãos congêneres estimam que ao longo dos mares possa ocorrer uma subida de $70 \mathrm{~cm}$ até o ano 2075 como resultado da expansão térmica, derretimento das geleiras alpinas e da Groenlândia, e a possível desintegração da Calota de Gelo da Antártida Ocidental (US NRC, 1987). Tal subida terá implicações ambientais bastante significativas.

Visando prover uma base quantitativa para a análise de sensibilidade dos impactos que devem avaliar a subida do nível do mar, em US NRC (1987), o comitê de especialistas em Engenharia Costeira adotou três plausíveis variações para a subida eustática do nível do mar até o ano 2100, correspondendo a 50, 100 e 150 $\mathrm{cm}$. Até o ano de 2010, a maior taxa recomendada produzirá uma subida de $10 \mathrm{~cm}$. Embora pareça uma subida relativamente pequena, há três situações em que seus efeitos são muito majorados (ALFREDINI, 2005):

1. Praias arenosas em costas expostas a ondas oceânicas, em que os processos naturais poderão causar erosões de $1 \mathrm{~m}$ ou mais para cada cm de subida do nível do mar (Regra de Bruun - Figura 2.10).

2. A cunha salina em estuários e trechos flúvio-marítimos poderá avançar até $1 \mathrm{~km}$ para uma subida de $10 \mathrm{~cm}$ no nível médio do mar, o que será preocupante especialmente quanto ao abastecimento de água potável e os ecossistemas costeiros durante as estiagens. Ocorrerá migração para montante da zona de turbidez máxima. 
3. Intrusão salina nos aqüíferos costeiros em que o deslocamento para terra da interface entre água salgada e doce corresponde a uma grande amplificação da correspondente subida do nível do mar.

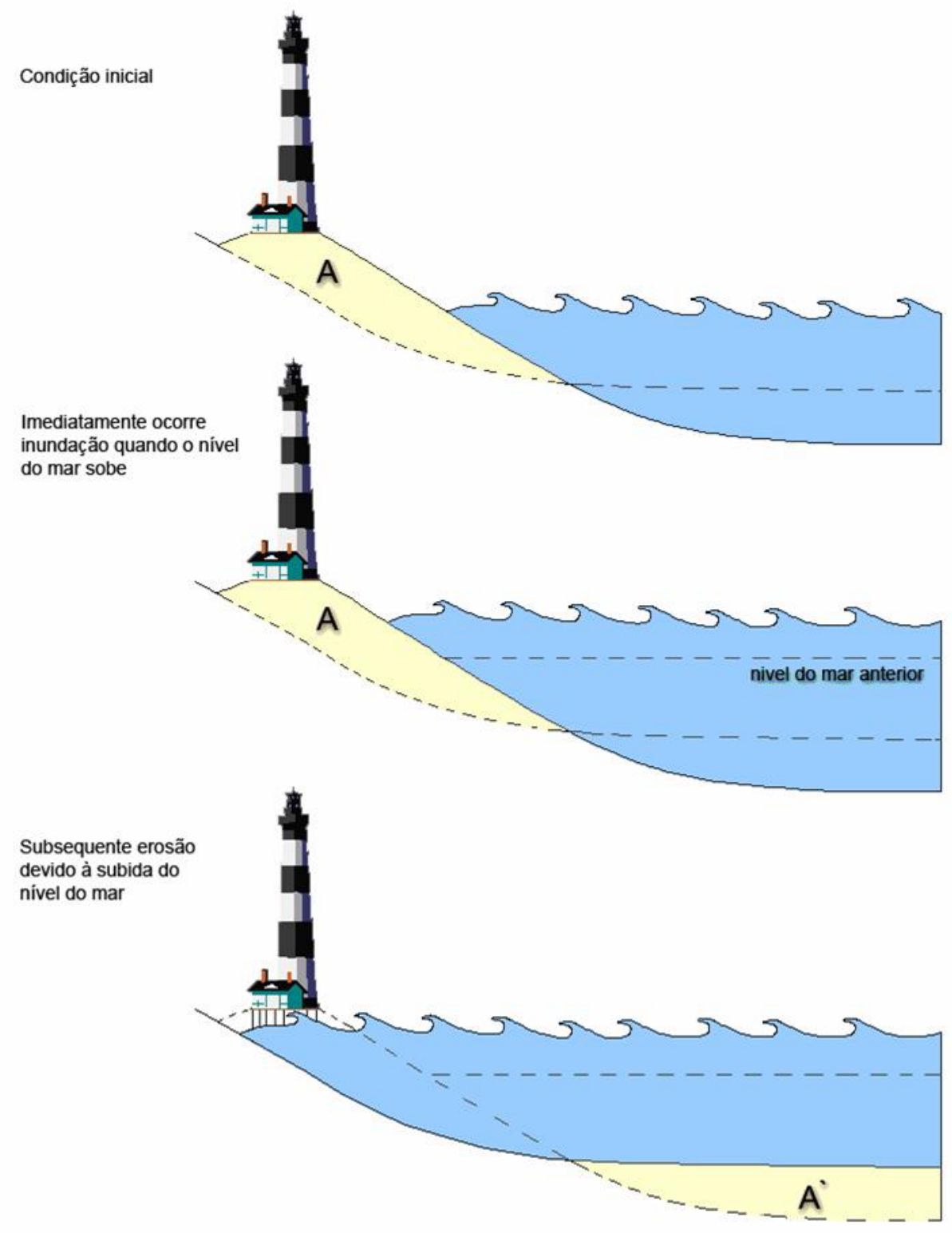

Figura 2.10 Regra de Bruun FONTE: Probio, 2005

A Fundação Centro Tecnológico de Hidráulica (FCTH) realizou um diagnóstico sobre os efeitos da elevação do nível do mar nos ecossistemas costeiros brasileiros e, com um modelo físico construído para a Baía e Estuário de Santos e São Vicente, procedeu a ensaios para os estudos dos impactos na região, ver o modelo na Figura 2.11. 


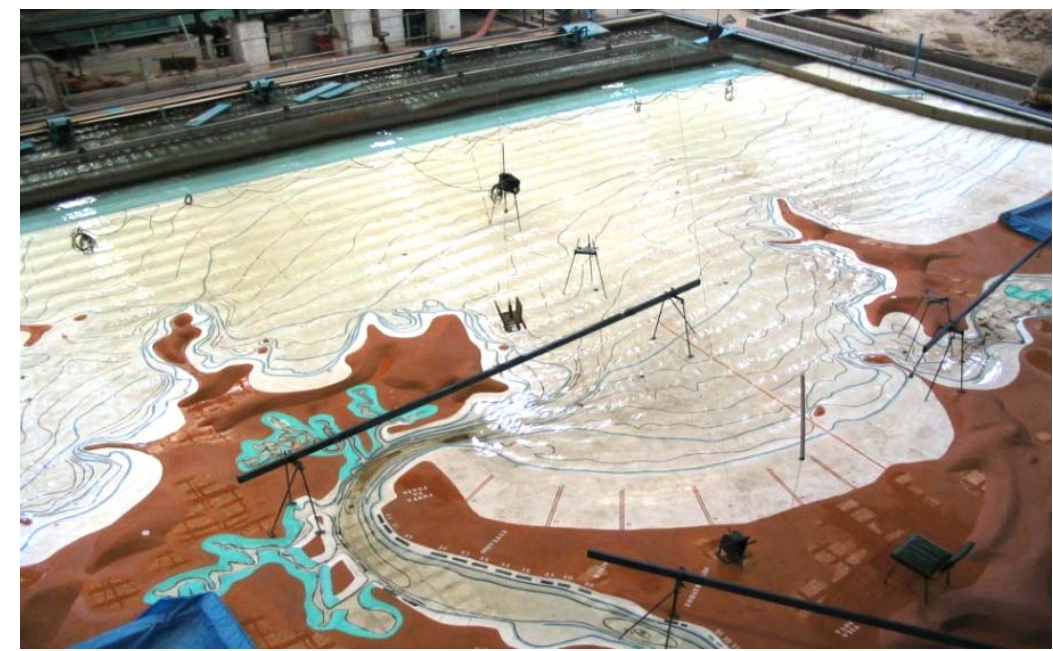

Figura 2.11 Vista do modelo físico (Laboratório de Hidráulica da EPUSP)

\subsubsection{Impactos}

Baseado nesses estudos, o futuro cenário será de inundações nas áreas urbanas e nos bosques de mangues, além dos impactos sobre a biodiversidade da região. Também estão contemplados os problemas da intrusão salina e das erosões costeiras.

Os efeitos da elevação do nível do mar nos ecossistemas costeiros irão variar dependendo do local, da velocidade dessa elevação e das respostas geológicas e biológicas dos ecossistemas afetados (Neumann et al. 2000).

O desastre global decorrente do aumento da temperatura não será marcado por um único e violento evento. Será em ondas progressivamente mais freqüentes e intensas, e suas conseqüências só serão percebidas num período de tempo maior.

A elevação do nível do mar trará a perda de áreas agricultáveis, havendo maior escassez destas áreas para suprir a demanda crescente de alimentos. Cidades costeiras e insulares serão destruídas, implicando no reassentamento da população em áreas mais altas, demandando a construção de cidades inteiras. Excessiva concentração de sal pode causar riscos à saúde pública, elevar o custo de tratamento da água, danificar equipamentos utilizados no mar e modificar a ecologia do estuário. (IPCC, 2002) 


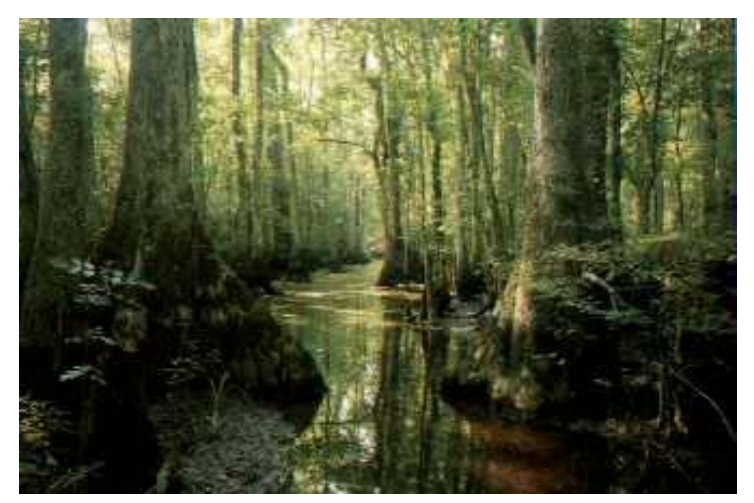

Figura 2.12 Alagamento do Manguezal FONTE: www.unicamp.br/fea/ortega/eco/mangue.jpg

Em regiões salinas como manguezais, Figura 2.12, a subida do nível do mar irá submergir as áreas úmidas causando a morte da vegetação por estresse salino (Kennedy et al. 2002). Segundo relatório do Probio (2005), o mangue é um ecossistema costeiro, de transição entre os ambientes terrestre e marinho, característico de regiões tropicais e subtropicais. É considerado um dos ecossistemas mais complexos, e mais férteis e diversificados do planeta. A sua biodiversidade faz com que essas áreas se constituam em grandes "berçários" naturais, tanto para as espécies típicas desses ambientes, como para aves, peixes, moluscos e crustáceos, que ali encontram as condições ideais para reprodução, criadouro e abrigo, tendo valor ecológico ou econômico. A perda desse ecossistema trará prejuízos incalculáveis.

O Brasil possui uma linha contínua de costa com mais de 8 mil quilômetros de extensão, uma das maiores do mundo. Ao longo dessa faixa litorânea é possível identificar uma grande diversidade de paisagens, como dunas, ilhas, recifes, costões rochosos, baías, estuários, terras úmidas, falésias, praias, restingas, lagunas e manguezais, apresentando assim diferentes espécies animais e vegetais. Com a elevação do nível do mar, grande parte desses ecossistemas sofrerá impactos irreversíveis.

Nas zonas costeiras e ecossistemas marinhos são esperados altos impactos devido ao aumento de temperatura da superfície oceânica e do nível do mar, mudanças na salinidade, condições adversas da maré e circulação oceânica, com significativas conseqüências em sociedades dependentes da pesca. Muitas áreas costeiras terão acelerada a erosão, provocando alagamentos com perda de ilhas e manguezais e mudando a taxa de concentração de sal no estuário, assim como a penetração de água salgada no curso de rios, obstruindo pontes de ligação entre as 
ilhas e o continente, causando também a destruição de ruas, acessos, estradas e rodovias localizadas no litoral, como ilustrado na Figura 2.13. A freqüência e intensidade de tempestades tropicais podem se tornar mais fortes, em virtude do aumento da temperatura global, com prejuízos para áreas como o litoral brasileiro.

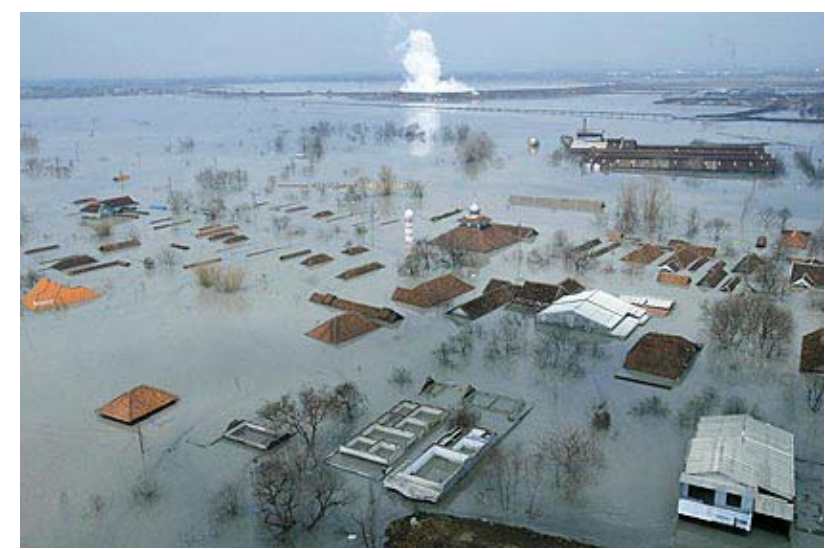

Figura 2.13 Inundações nas Áreas Urbanas (Indonésia, 2007) FONTE: centraldenoticias.files.wordpress.com/2007/04/inundacao.jpg

A erosão marinha modifica todo o litoral e é causada, fundamentalmente, pela ação de três fatores principais: ondas, correntes e marés. Essa erosão ocorre tanto nas costas rochosas, como nas praias arenosas. Nos costões rochosos, a ação erosiva do mar forma as falésias. Nas praias arenosas, a ação erosiva do mar causa o recuo da mesma, ocorrendo o transporte de sedimento, onde o sedimento removido pelas ondas é transportado lateralmente pelas correntes litorâneas longitudinais.

Nas praias arenosas a erosão constitui um grave problema para as populações costeiras. Os danos causados podem ir desde a destruição das habitações e infra-estruturas humanas, até graves problemas ambientais. Para retardar ou solucionar o problema, podem ser tomadas diversas medidas de proteção, sendo as principais soluções: as construções pesadas de defesa costeira e a realimentação de praias.

Os impactos decorrentes da elevação do aumento do nível do mar estão associados aos principais setores de uso e ocupação do solo na zona litorânea e podem ser resumidos em impactos sobre:

- Áreas baixas e urbanizadas, sujeitas a alagamentos e inundações;

- Equipamentos de infra-estrutura urbanas; 
- Transporte viário incluindo vias internas, pontes e rodovias intermunicipais;

- Atividade portuária e os terminais marítimos especializados;

- Atividade industrial;

- Corpos d'água litorâneos e costeiros.

Em março de 2004, devido à temperatura anormalmente alta das águas do Atlântico Sul, o ciclone extratropical Catarina evoluiu para a costa de Santa Catarina e Rio Grande do Sul, com estrutura de Furacão I. Com ventos de mais de 180 km/h, destruiu quase 1.500 construções, danificando mais de 40.000. A catástrofe ainda resultou na morte de 14 pessoas e o prejuízo foi de $\mathrm{R} \$ 1$ bilhão, ver Figura 2.14.
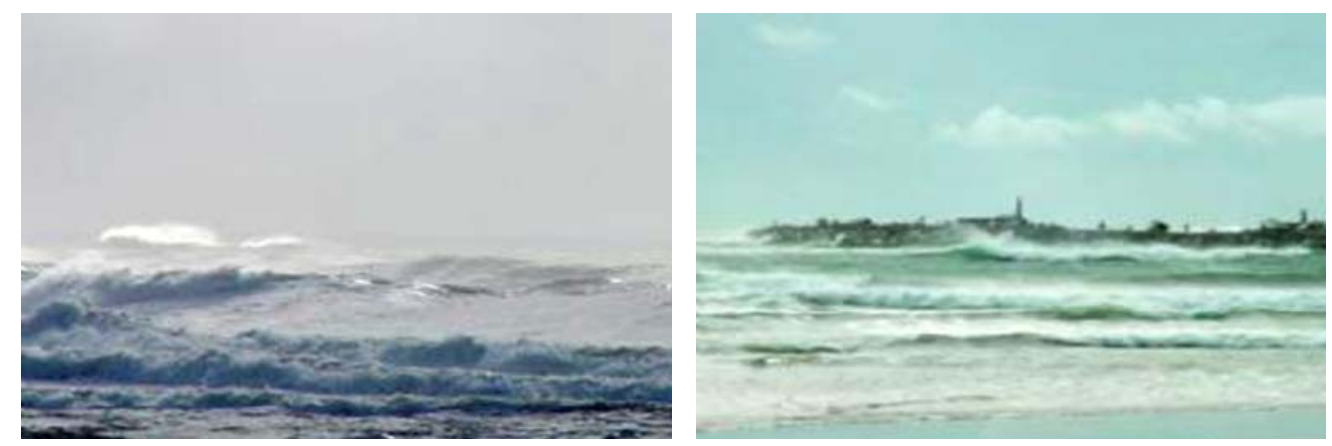

Figura 2.14 Ciclone Extratropical Catarina (SC / RS, 2004)

Em Santos (Figura 2.15), uma tempestade com maré meteorológica ocorreu em abril de 2005. Ondas de até 4 metros de altura se formaram na Baía de Santos, onde o nível médio do mar elevou-se $80 \mathrm{~cm}$ em relação à maré astronômica prevista para a data.

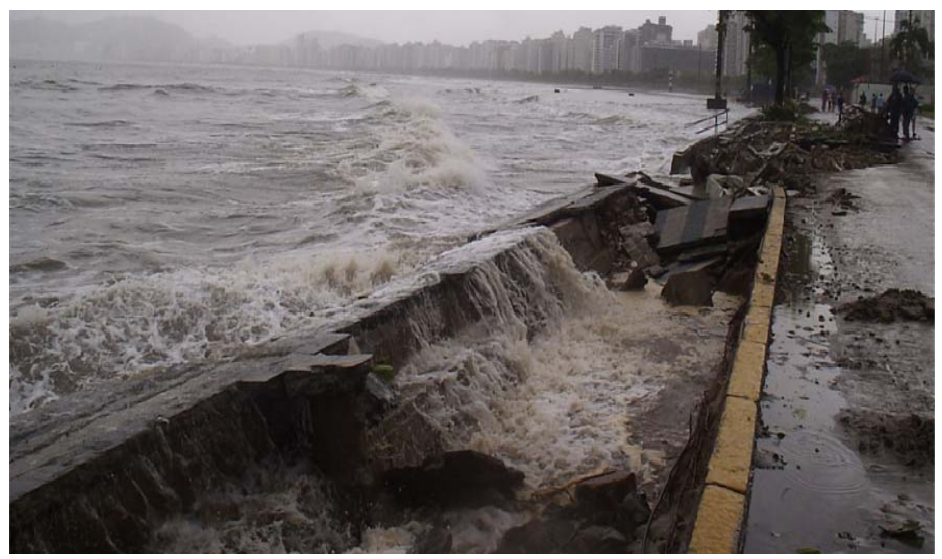

Figura 2.15 Ressaca do dia 26 de Abril de 2005 (Santos - SP) 


\subsection{POLÍTICAS PÚBLICAS}

Embora, desde a década de 80, um grande número de informações tenha sido acumulado sobre a questão, há uma carência de avaliações quantitativas, em especial no cenário nacional. Assim, torna-se necessário dispor de respostas quantitativas sobre as respostas físicas e biológicas dos sistemas costeiros e estuarinos. Somente procedendo dessa maneira, poderão ser adotadas as políticas públicas coerentes de estratégias de Gerenciamento Costeiro.

Segundo o IPCC, as instituições envolvidas no gerenciamento dos sistemas costeiros têm muitas opções práticas para reduzir os riscos relacionados aos eventos climáticos extremos atuais e suas variações, bem como se adaptar às mudanças climáticas. Isso reflete o fato de que muitas estratégias de resposta a mudanças climáticas e desastres são as mesmas que contribuíram positivamente para os esforços atuais em implementar o desenvolvimento sustentável, incluindo melhorias na igualdade social, o bom gerenciamento ambiental e o uso sábio dos recursos naturais (Helmer e Hilhorst, 2006).

A restauração e gerenciamento do rio Mississippi, e sua planície de delta, exemplifica que a identificação e seleção das opções de adaptação podem ser guiadas pela experiência e pelas melhores práticas de redução de impactos adversos, apesar de algumas vezes não relacionados, a fenômenos análogos, como subsidência (natural ou induzida pelo homem) e tsunami (Oslen et al.,2005). Baseado nessa experiência é altamente vantajoso integrar o gerenciamento de desastres e as adaptações para variações e mudanças climáticas em um, mais amplo, gerenciamento costeiro, especialmente se considerarmos as importantes lições aprendidas com os recentes desastres.

Os estudos de viabilidade para projetos costeiros deveriam ser licenciados considerando os seguintes cenários.

- Cenário 1 - "Esperar para ver" - "Deixar a natureza tomar o seu curso" - As estruturas são mantidas, tanto quanto for possível manter condições satisfatórias, até que tenham que ser abandonadas. 
- Cenário 2 - "Recuar, planejando antecipadamente" - "Adotar solução de compromisso" - As decisões de remover os habitantes expostos para áreas mais altas são tomadas pelas autoridades com certa antecedência.

- Cenário 3 - "Proteger" - "Estabilização da linha de costa" - As principais estruturas serão protegidas por obras de defesa rígidas ou engordamentos de praia. Neste caso, vale ressaltar que proteger com obras de defesa não soluciona o problema, mas apenas permite sua administração, sendo necessária a adoção do gerenciamento costeiro.

Klein et al. (2001) descreve três tendências: (i) crescente reconhecimento dos benefícios da proteções leves nas estratégias do tipo recuar e acomodar; (ii) uma crescente dependência das tecnologias para desenvolver e gerenciar a informação; e (iii) uma melhor consciência da necessidade de adaptações costeiras que reflitam as condições naturais e sócio-econômicas locais. A decisão sobre escolher qual a melhor opção de adaptação tende a ser altamente influenciada por considerações sócio-econômicas (Knogge et al., 2004; Persson et al., 2006).

Também é importante considerar as medidas de adaptação que reduzem as ameaças diretas à sobrevivência dos ecossistemas costeiros.

O valor da estrutura de proteção não deve ser maior do que o valor da área a ser protegida. Portanto, antes de decidir qual o melhor cenário a ser implantado, é necessário obter e gerenciar todos os diversos tipos de informações.

Por exemplo, poucas são as medições de ondas disponíveis para o litoral paulista. Não há uma sistemática para o levantamento desses dados e nenhum programa governamental para a criação e consolidação de um banco de dados de ondas (Araújo, 2005). As medições normalmente originam-se da necessidade de projetos específicos, ou estimam-se os dados utilizando os modelos numéricos, e muitas vezes sua disponibilidade pública não acontece. Disto, observa-se uma grande falha na política de gerenciamento costeiro, e uma grande dificuldade em tomar decisões a respeito dos projetos costeiros. 


\subsection{PROJETOS DE OBRAS MARÍTIMAS}

As obras de defesa costeira são intervenções estruturais que tem a função de agir no balanço do transporte sólido favorecendo a estabilização ou ampliação da linha de costa, defendendo contra a erosão, restabelecendo sistemas naturais (falésias, dunas, zonas úmidas e praias), assim como defendendo contra possíveis inundações, alagamentos, protegendo as obras civis (edifícios, infra-estruturas, rodovias) na orla costeira.

Devem ser considerados no projeto das obras de defesa dos litorais os fenômenos naturais, pois as praias respondem às mudanças climáticas da natureza; o custo-benefício da obra, considerando inclusive a manutenção ao longo da vida útil; os aspectos ambientais, preocupando-se com a qualidade da água, com os organismos, a poluição nos sedimentos provindos de áreas de empréstimo; os aspectos sociais como planos de emergência locais para as zonas costeiras, saúde pública e segurança da população; e o aspecto estético que minimiza os impactos visuais sobre uma praia, garantindo mínima influência nas áreas adjacentes.

O ambiente costeiro varia espacial e temporalmente, conseqüentemente, um desenho que é funcional, econômico e ambientalmente apropriado em uma determinada localização poderia ser inapropriado em outra. Portanto exige um apurado estudo de projeto, utilizando modelos físicos e matemáticos, pois obras mal estudadas ou improvisadas agravam a erosão na área ou adjacências. Dessa maneira é importante estudar o comportamento das obras costeiras nas proximidades, nas situações extremas e dominantes das áreas.

As intervenções não estruturais são medidas que não interferem no litoral, atuando apenas no aspecto sócio-econômico, reduzindo assim as intervenções estruturais que devem ser adotadas como último recurso.

Para analisar as causas da erosão, e, portanto, definir qual o tipo de obra mais adequado, é necessário entender a dinâmica da praia, o balanço sedimentar, o transporte litorâneo, a evolução histórica das linhas de praia, os regimes de vento, de marés, de ondas e das correntes marítimas.

As obras de proteção costeira podem ser classificadas, quanto à sua localização, em obras longitudinais aderentes (paredões, construídos na interface terra-mar); obras transversais (espigões); obras longitudinais não aderentes (quebra- 
mares destacados); alimentação artificial das praias; diques; fixação de dunas de areia; e comportas.

\subsubsection{Obras Longitudinais Aderentes}

Obras longitudinais aderentes são estruturas verticais de contenção também chamados de paredões, construídos na interface terra-mar. São empregados para fixar os limites da praia, ao longo das linhas de costa não protegidas adequadamente pela praia natural, sendo na maioria dos casos, obras emergenciais (provisórias) em áreas seriamente afetadas pelo mar, a fim de evitar o recuo da praia. Também podem ser empregadas como obras definitivas quando se pretende manter a costa em posição avançada com relação às áreas vizinhas, como no caso de avenidas beira-mar.

Estas obras, apropriadamente executadas, desempenham uma ótima resistência à ação de ondas mais severas, podem ser usadas também como muro de arrimo para contenções de aterro ou praias artificiais, e são capazes de evitar inundações no período de eventos meteorológicos mais intensos, nesse caso são chamados de muros de choque, ilustrados nas Figuras 2.16 e 2.17 .

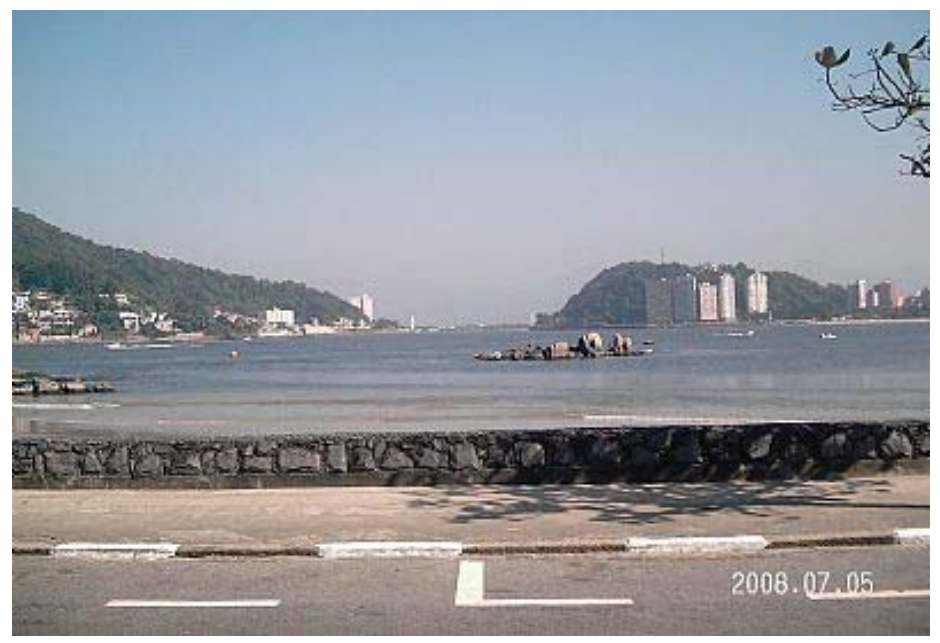

Figura 2.16 Paredão na Praia de Milionários (São Vicente / SP) FONTE: guiadolitoral.uol.com.br 


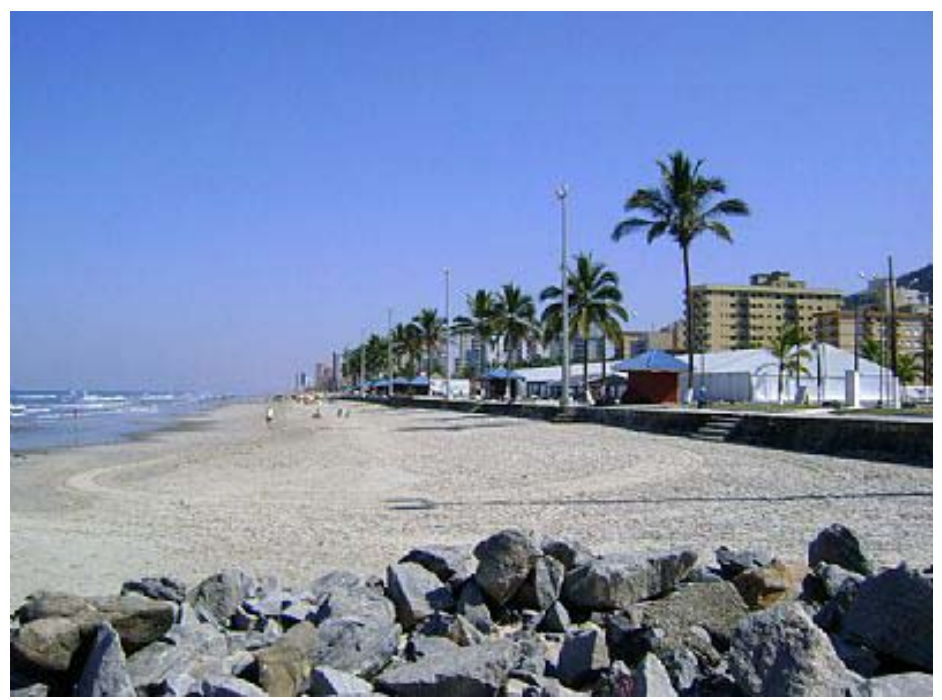

Figura 2.17 Mureta de Alto da Praia em Mongaguá / SP (Praia Central) FONTE: guiadolitoral.uol.com.br

Porém, há algumas limitações no seu desempenho que devem ser levadas em consideração, como a não retenção dos sedimentos em trânsito, contribuindo para a erosão da própria base, mas este fator pode ser aliviado pelas obras conjuntas de enrocamento. As ondas refletidas na face do muro vertical podem leválo à ruína (ver esquema na Figura 2.18). Com a tendência do desaparecimento da praia frontal, aumenta o risco da obra ser galgada pelo escoamento, erodindo assim o seu tardoz, desestabilizando a estrutura. Essa condição poderá ser observada no estudo de caso - Rodovia SP-55 / Praia de Massaguaçu - detalhado nesse relatório adiante. Os extremos de barlamar e sotamar também devem ser protegidos por muros de cabeceira. 

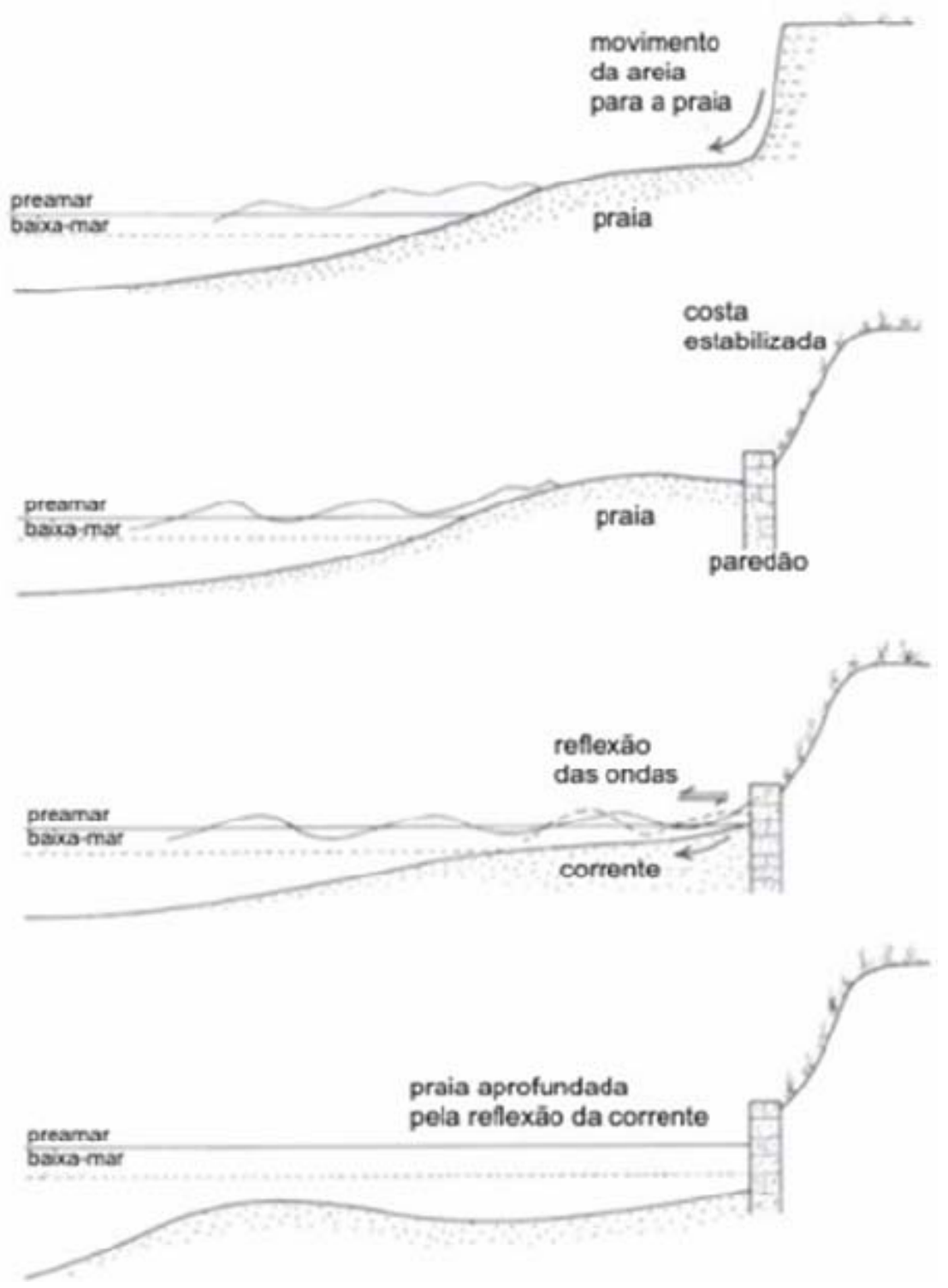

Figura 2.18 Processo de Erosão (Paredões) FONTE: Alfredini, 2005

Nos muros de choque são mais comumente usadas as peças maciças de concreto, mas podem ser construídos com estacas prancha de concreto, estacas metálicas ou de madeira.

Já o revestimento de alto da praia são estruturas flexíveis, que conferem menor resistência à energia das ondas e correntes. Resistem à ação das ondas fracas e moderadas. 


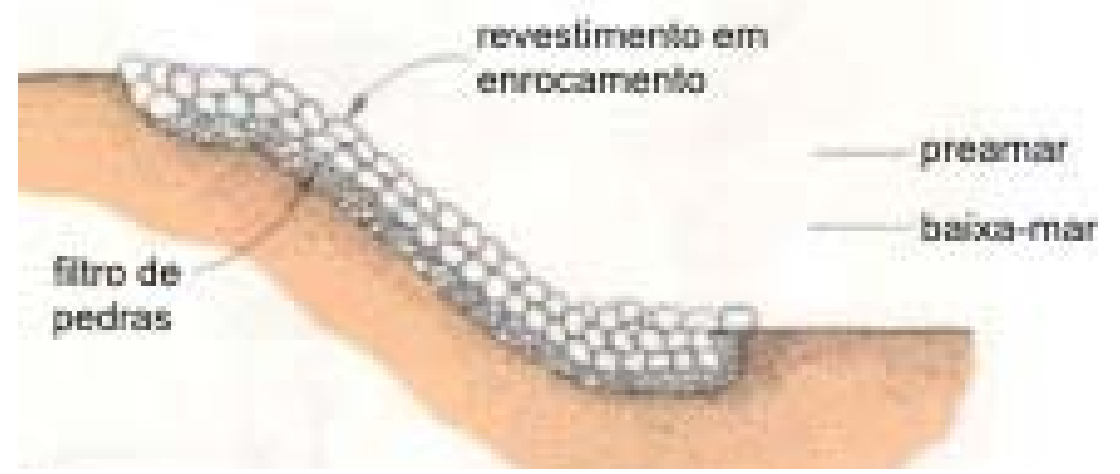

Figura 2.19 Revestimento de Alto da Praia FONTE: Alfredini, 2005

Os revestimentos (detalhe na Figura 2.19), somente atingidos pelas ondas nas preamares excepcionais, podem ser construídos com muretas baixas, em concreto ou alvenaria de pedra, gabiões, enrocamentos, e estacas pranchas (madeira ou metálica). Exemplo na Figura 2.20.

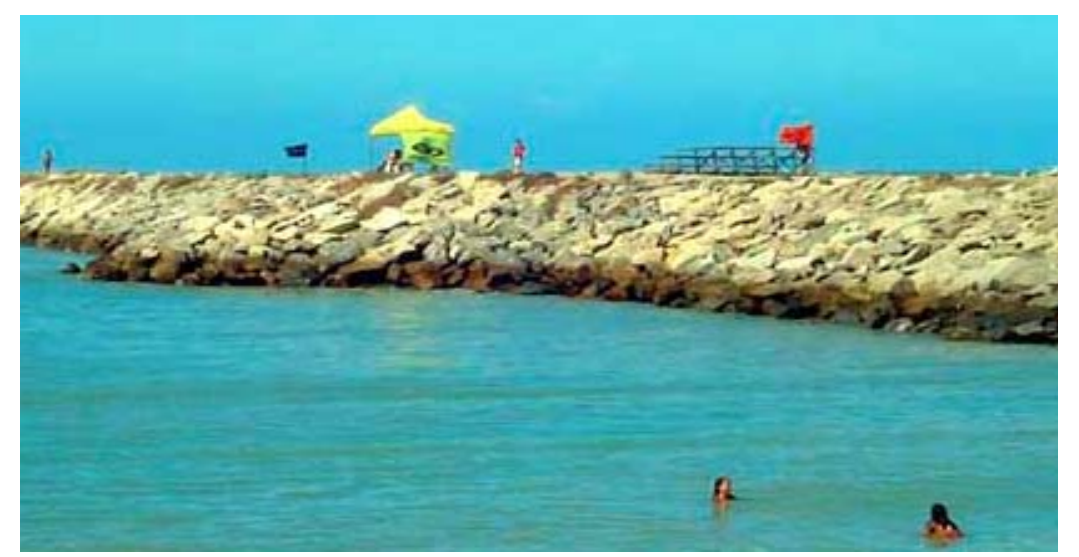

Figura 2.20 Revestimentos de alto da praia (Praia de Iracema, Piauí) FONTE: www. kitesurfmania.com.br

\subsubsection{Obras Transversais}

Espigões de praia são estruturas transversais que se estendem do pós-praia, suficientemente enraizadas para não serem contornadas pelo espraiamento, até a primeira linha de arrebentação, agindo na faixa mais significativa do transporte de sedimentos litorâneo, ilustrado nas Figuras 2.21 e 2.22 .

Sendo assim essas obras interceptam o transporte de sedimentos, ocasionando o depósito a barlamar, evitando o assoreamento a sotamar, 
estabilizando assim a praia sujeita a variações periódicas. Também pode ampliar a largura da praia para fins balneários ou de reurbanização, e complementar a fixação da areia para a alimentação artificial das praias.

As construções de espigões não são indicadas para áreas onde o transporte de sedimentos litorâneo for fraco, pois as erosões a sotamar podem ser graves. Isto também pode ocorrer quando o rumo deste transporte de sedimentos for variável, pois reduz a eficácia da obra.

Essas obras não evitam as erosões causadas pelas correntes de retorno transversais, e criam turbulências nas suas extremidades, podendo produzir erosões que levam a ruína da estrutura, se não for mantido esquema operacional de manutenção adequado.

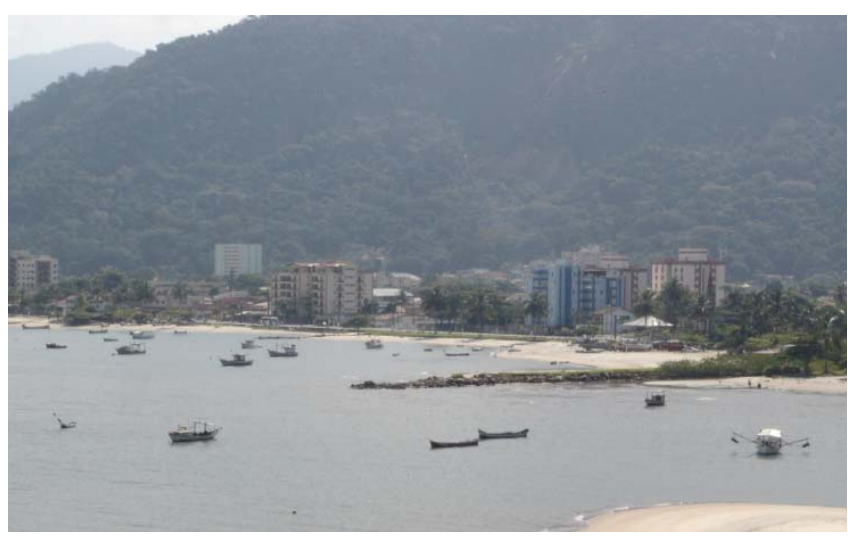

Figura 2.21 Espigão de Praia em Caraguatatuba (SP)

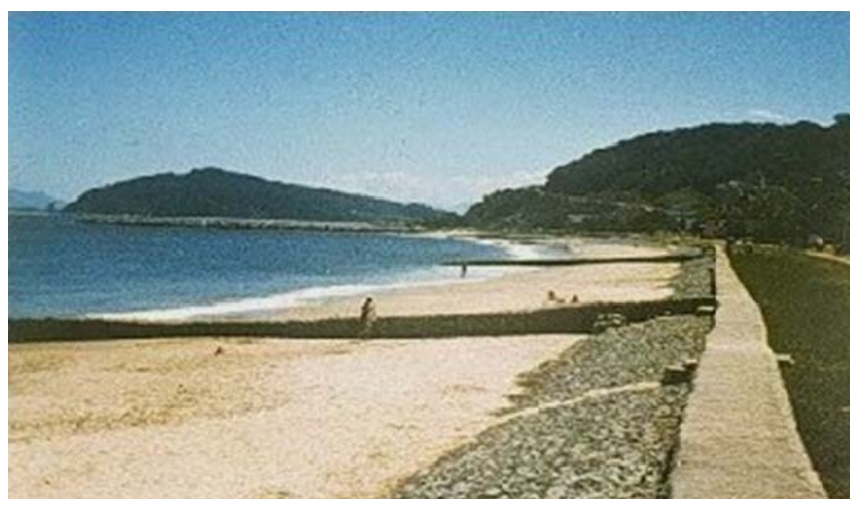

Figura 2.22 Praia Mansa de Caiobá (PR)

FONTE: www.netpar.com.br

O espigão pode ser também empregado em conjunto com outros espigões, sendo chamado de campo de espigões. Esse campo de espigões caracteriza-se pela criação, ou proteção, de uma extensa faixa de praia. Pode funcionar como obra 
fundamental na formação da praia com o transporte litorâneo natural, ou como obra complementar, reduzindo os volumes de alimentação da praia, na formação da praia com alimentação artificial de areia, ver Figura 2.23.

Num campo de espigões, a construção pode ser efetuada em etapas iniciando de sotamar, adicionando novos espigões sempre que for atingida a capacidade de retenção máxima, e os sedimentos começarem a contornar a obra. De outro modo, quando a construção do campo de espigões se realiza numa só etapa, os espigões de barlamar preenchem primeiro, sendo o campo de espigões preenchido seqüencialmente de barlamar para sotamar na medida em que os espigões de barlamar são preenchidos e os sedimentos os contornam.

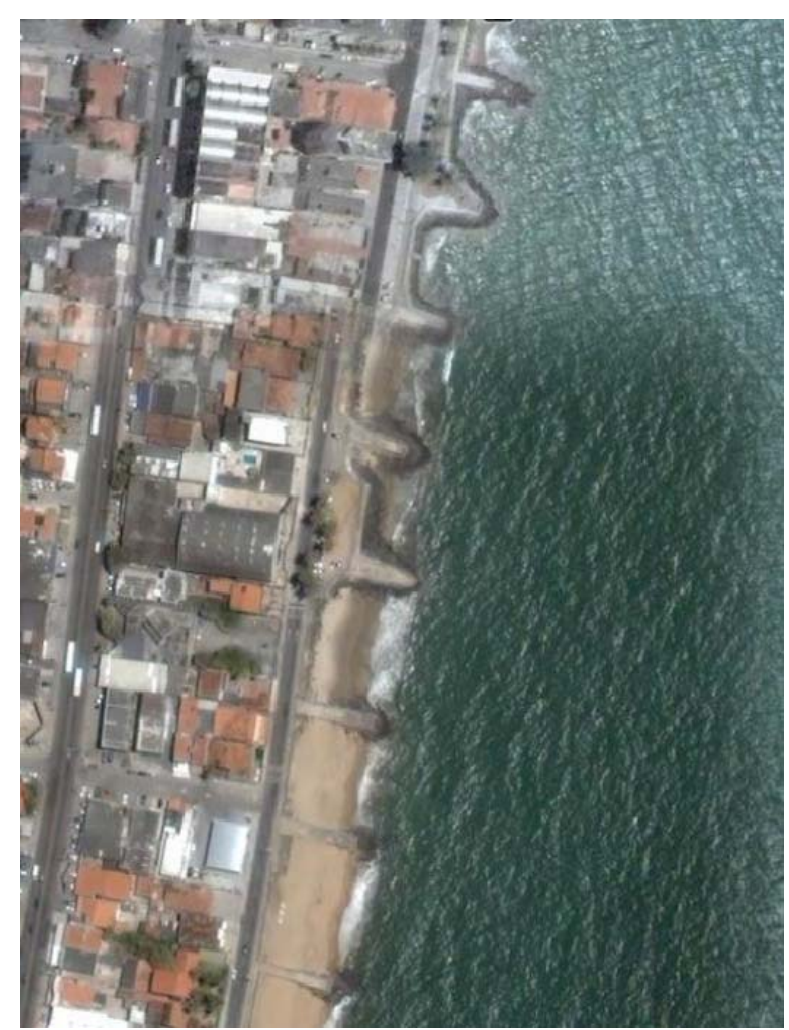

Figura 2.23 Campo de Espigões (Olinda / PE) FONTE: Google Earth

O enrocamento é o material mais utilizado na construção de espigões, com a vantagem de formar estruturas flexíveis, adaptáveis aos assentamentos do terreno. Também é possível aplicar o sistema de gabiões, particularmente nos trechos em que as estruturas ficarão assoreadas, ou sacos preenchidos com argamassa de alta resistência. Também são utilizadas estacas prancha metálicas planas ou celulares 
preenchidas de agregados, de concreto, ou de madeira (indicadas em áreas de agitação menos intensa).

\subsubsection{Obras Longitudinais Não Aderentes}

As obras longitudinais não aderentes também são chamadas de quebramares destacados da costa, e levam este nome por serem estruturas paralelas construídas a certa distância da costa, portanto não ligadas à mesma, implantadas em áreas de profundidades maiores do que os espigões, com a função de defesa da costa. São estruturas que não interrompem completamente as ondas incidentes, são apenas colocados como uma barreira encontrada pelas ondas, para dissipar a energia, prevenindo a erosão na zona de sombra da obra na costa, como na Figura 2.24 .

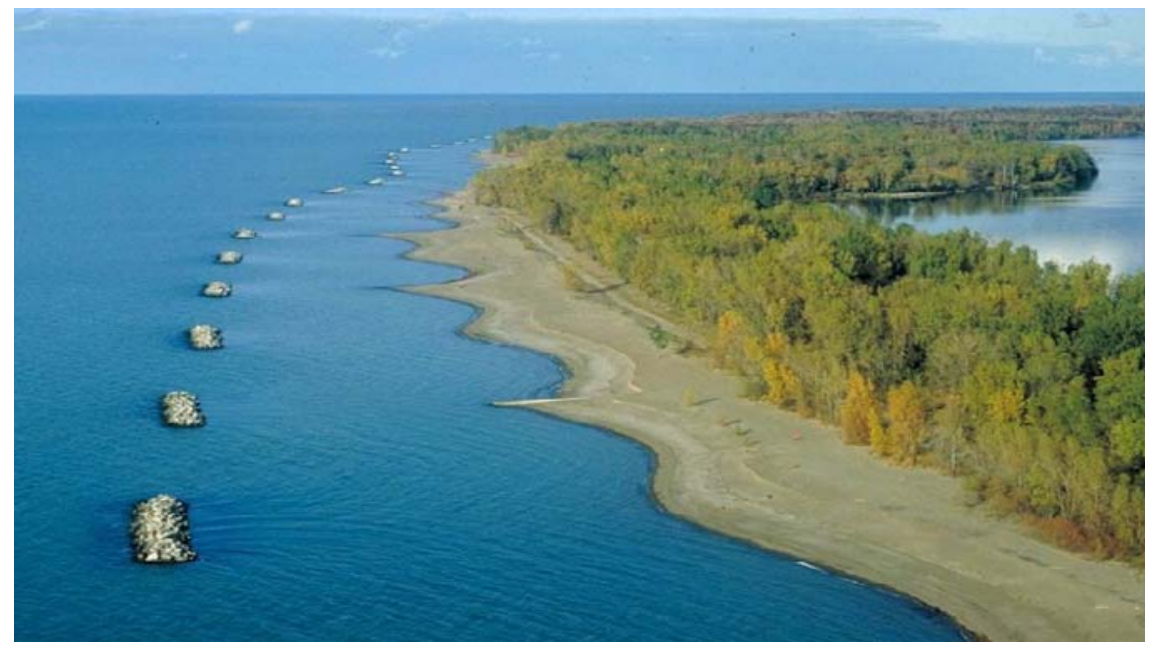

Figura 2.24 Quebra-Mares na llha de Presque (Pensilvânia / USA) FONTE: Google Earth

Na sombra da obra, existe a tendência de formação de uma saliência, o tômbolo, que promove a proteção da orla da praia. Essa estrutura também pode ser desenvolvida de maneira natural, como na Figura 2.25, através da sombra de uma ilha. 


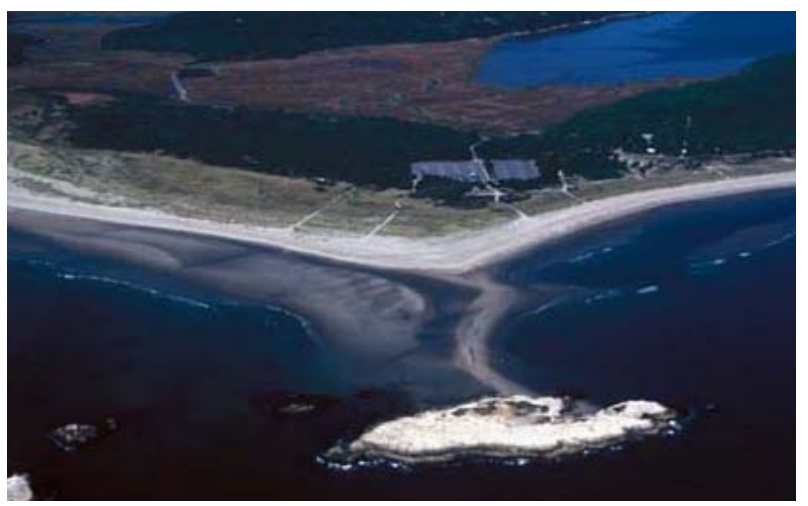

Figura 2.25 Tômbolo formado pela llha (Maine / EUA) FONTE: www.geology.um.maine.edu/gallery

Os quebra-mares destacados podem ser usados em áreas sem apreciável transporte litorâneo, sendo freqüentemente constituídos por estruturas segmentadas com vãos que têm a finalidade de renovação da água, melhorando a sua oxigenação e favorecendo a balneabilidade da praia. Devem evitar a formação de tômbolos muito desenvolvidos (Figura 2.26), que podem representar problemas sanitários, reduzindo a capacidade de renovação das águas, aumentando os índices de poluição. Podem ser emersos ou submersos, sendo que neste último caso os vãos entre as obras não são necessários.

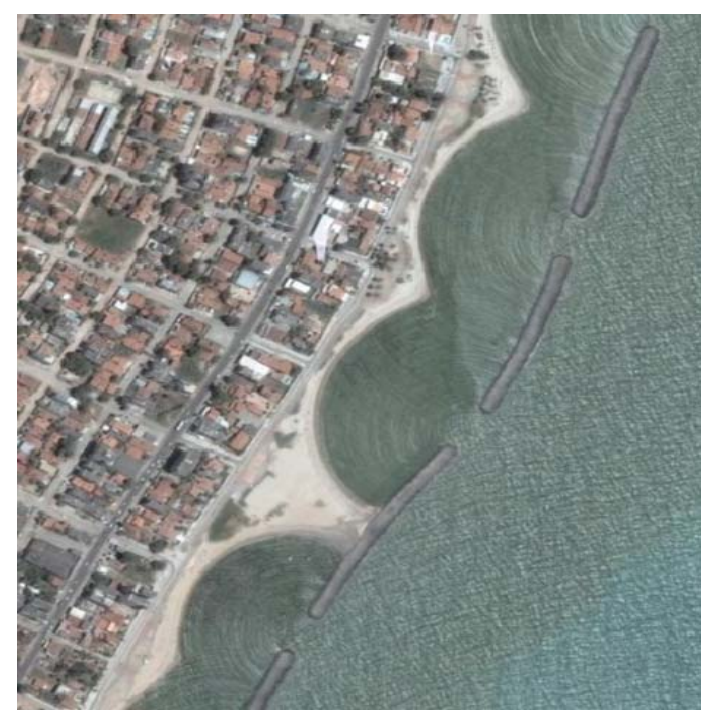

Figura 2.26 Tômbolo formado pelo Quebra-Mar (Paulista / PE) FONTE: Google Earth

Estudos de impacto da utilização dos quebra-mares devem ser realizados antes de sua implantação levando-se em conta que não são aconselháveis em locais com grandes excursões de maré, pois a eficiência do sistema depende da 
cota do coroamento da obra, nem em locais com grande declividade do terreno por exigirem obras em grandes profundidades gerando alto custo de construção. Não são obras flexíveis que se adaptarão ao crescimento da praia e podem também apresentar riscos à navegação (submersos). Esteticamente, são obras desagradáveis, principalmente os quebra-mares emersos.

O enrocamento, de modo geral, é o material mais utilizado na construção, compondo quebra-mares de talude. Os blocos artificiais de concreto são utilizados em obras em maiores profundidades, podendo formar estruturas denominadas recifes artificiais. Em áreas mais abrigadas podem-se utilizar estacas metálicas ou de madeira.

\subsubsection{Alimentação Artificial de Praias}

A alimentação artificial de praias consiste no suprimento de areia com material adequado obtido das áreas de empréstimo. Trata-se de solução temporária quando não se conhecem suficientemente as causas da erosão. Esta obra permite estabilizar ou ampliar praias sujeitas à erosão, ou criar nova praia, que é a configuração morfológica mais adequada para absorver a energia das ondas (praia de proteção).

Esta alternativa também pode ser utilizada para acelerar o enchimento de campos de espigões, ou sistema de quebra-mares destacados.

É uma intervenção estrutural reconhecida como uma das melhores defesas contra a erosão costeira, considerando que não necessita de obras fixas, estranhas ao ambiente natural, que são de eficiência difícil de ser prevista com efeitos colaterais nas áreas adjacentes. Neste caso, os efeitos não previstos de excessivo arrastamento das areias podem até favorecer praias adjacentes.

A alimentação artificial de praia pode ser considerada como uma forma bastante natural de combater a erosão costeira, pois está repondo artificialmente um déficit no balanço sedimentar num trecho de praia com volume correspondente. Se a causa da erosão não for eliminada um projeto de alimentação não será eficiente, assim este projeto normalmente requer manutenção em longo prazo, ver esquema na Figura 2.27. 


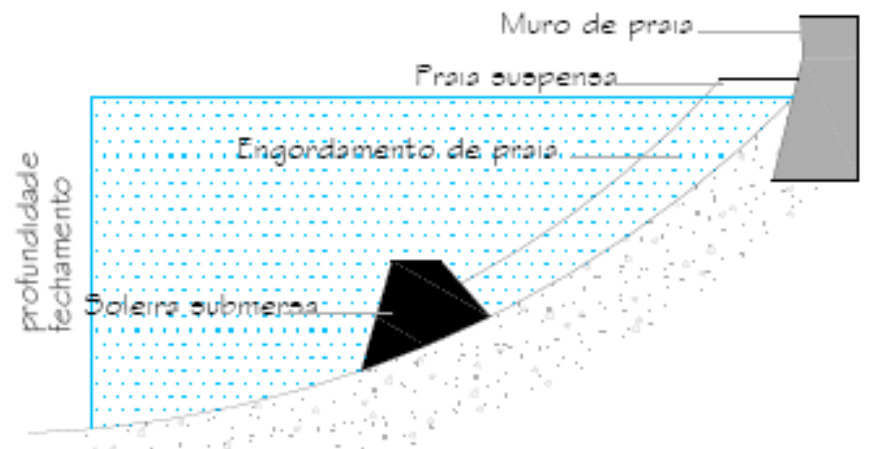

Figura 2.27 Esquema da Praia Artificial FONTE: Alfredini, 2005

A disponibilidade e o custo econômico do material de empréstimo é um fator limitante nesse tipo de obra. No caso de transposição de areias, a interrupção do sistema pode produzir grandes erosões a sotamar, e as instalações fixas de transposição de areias têm pouca flexibilidade, podendo haver inconvenientes.

Devem ser considerados os aspectos ambientais nas áreas de empréstimo e de depósito. O projeto depende de fatores técnicos, características e volumes dos materiais, fatores econômicos, distância de transporte, obras e equipamentos e fatores ambientais.
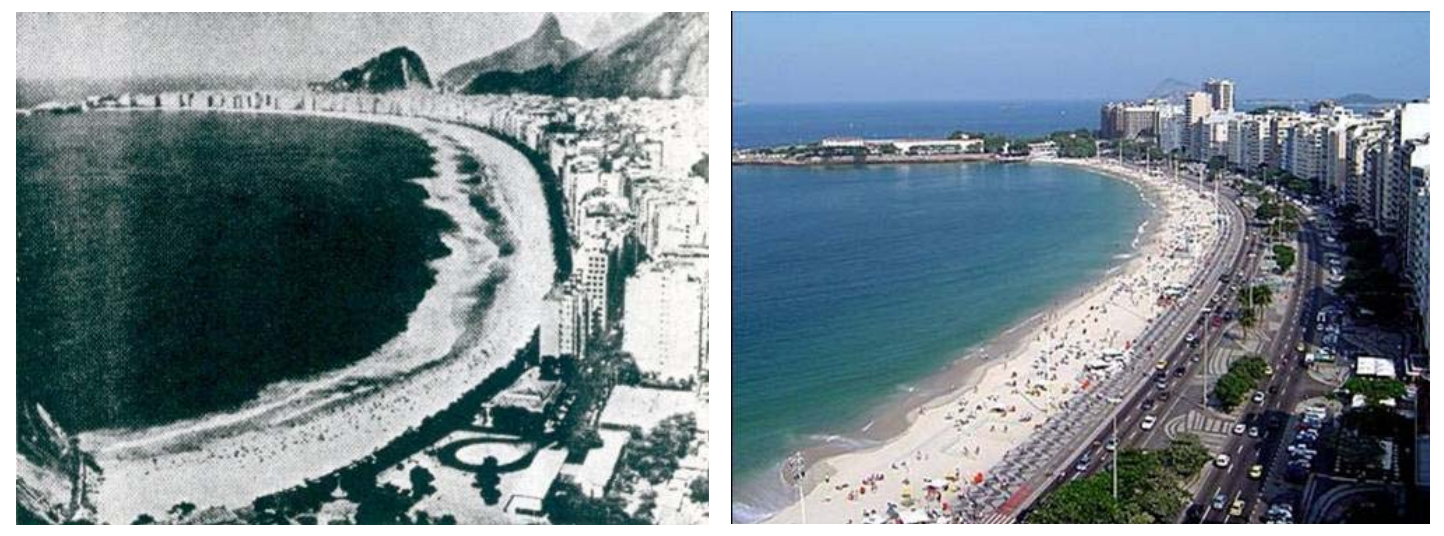

Figura 2.28 Alimentação Artificial da Praia de Copacabana (RJ) FONTE: www.copacabana.com

A Figura 2.28 comprova o sucesso desse processo, e esse sucesso de engordamento artificial de praias depende muito da granulometria da areia de empréstimo em comparação à granulometria da areia nativa. Sabe-se que as características da areias são determinantes no estabelecimento da forma geral do 
perfil transversal da costa, através do conceito de perfil de equilíbrio, além do que existe uma graduação granulométrica que varia ao longo do perfil praial, em função do processo hidrodinâmico. No caso do material de empréstimo ser mais grosseiro do que o nativo, haverá tendência do perfil praial tornar-se mais íngreme do que o natural, sendo mais estável quanto às perdas para o transporte de sedimentos litorâneo. No caso contrário haverá a tendência de formar-se um perfil mais suavizado que o natural, requerendo um grande volume de areia, ilustrado na Figura 2.29.

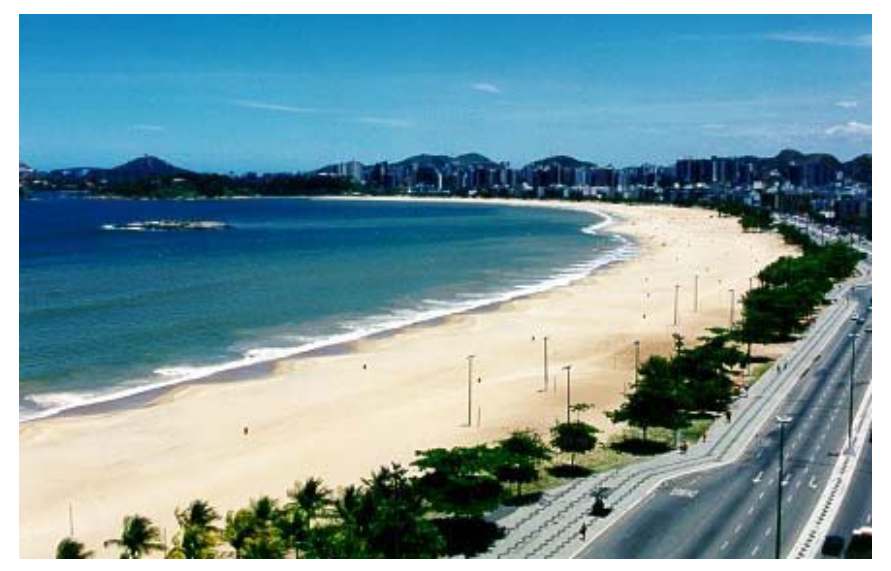

Figura 2.29 Alimentação Artificial da Praia de Camburi (Vitória / ES)

FONTE: spintravel.blogtv.com.pt/img/Image/Spintravel/2007/Novembro/camburi1.jpg

\subsubsection{Diques}

Diques são estruturas de proteção costeira de áreas baixas e terrenos costeiros contra inundações por ocasião das grandes ressacas. Normalmente são constituídos de areia com camadas de terra e grama em áreas que não apresentam problemas de erosão. Em costas sujeitas à erosão possuem revestimentos mais resistentes a fim de evitar seu solapamento (Figura 2.30).

A extensão frontal ao dique atenua a ação das ondas, normalmente construídos com taludes muito suaves e com vegetação densa e bem enraizadas, favorecendo a estabilidade da obra. No cenário em que a costa frontal está sujeita a erosão deve-se revestir o trecho do dique, com colchão de concreto articulado, para evitar solapamento, e proteger a base com revestimento em enrocamento. 


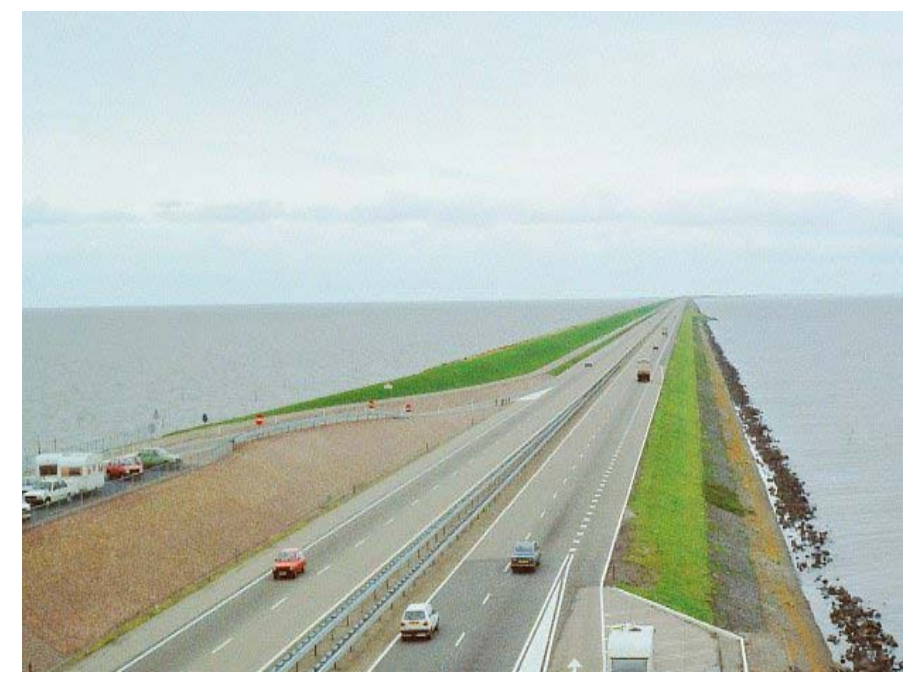

Figura 2.30 Dique separando o Mar do Norte do Lago de IJsselmeer (Holanda) FONTE: pt.wikipedia.org/wiki/Dique

\subsubsection{Fixação de Dunas de Areia}

As dunas de areia móveis são constituídas de material incoerente movido pelo vento, sendo pouco convenientes do ponto de vista da proteção dos litorais. Já as dunas fixadas são vantajosas para a defesa dos terrenos costeiros, pois constituem barreiras contra as inundações das marés, podendo ainda ser fonte de areia para as praias erodidas.

Um dos processos para a fixação das dunas é a implantação de ante-dunas criadas artificialmente (ver Figura 2.31). Cercas de madeira são utilizadas para obstruir a ação do vento, fixando e acumulando areia, ao mesmo tempo em que é plantada vegetação (gramíneas e arbustos naturais) na nova formação para propiciar melhor resistência. 


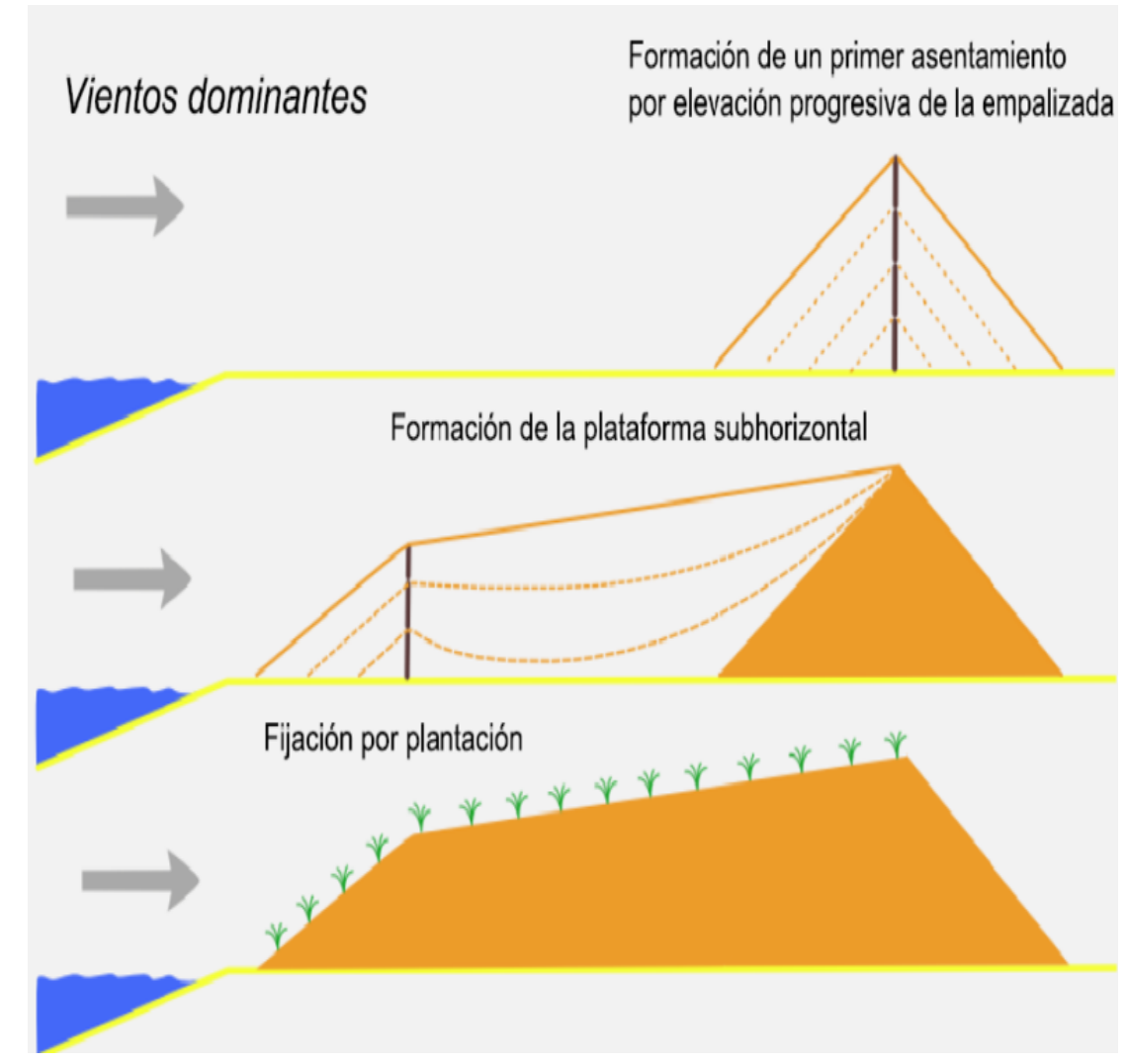

Figura 2.31 Esquema da técnica de Fixação de Dunas (Aquitania / França) FONTE: pt.wikipedia.org/wiki/Duna de Pyla

Outro processo é a utilização da própria areia da praia através de equipamentos próprios. No entanto, após a tempestade, a manutenção para reconstruir a duna é obrigatória, garantindo a proteção e segurança da população, ver Figura 2.32.

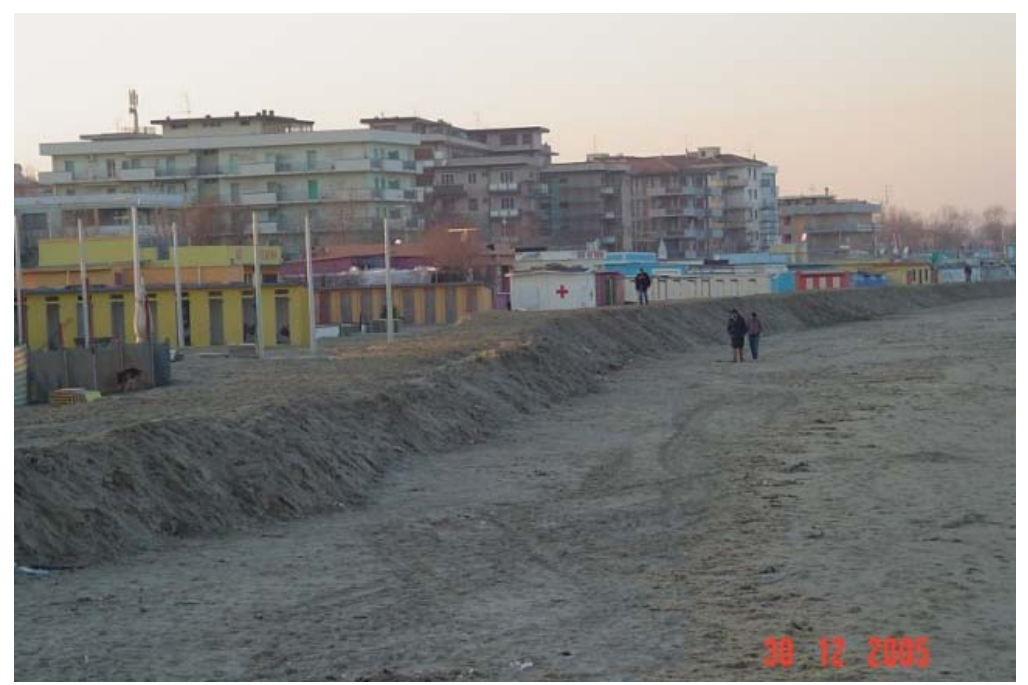

Figura 2.32 Duna artificial na Região de Cesenático (Itália) 


\subsubsection{Comportas}

A comporta é uma estrutura de proteção e se compõe basicamente de três elementos: tabuleiro, peças fixas e mecanismo de manobra. $O$ tabuleiro, componente principal da comporta, é um elemento móvel que serve de anteparo à passagem da água e é constituído de paramento, chapa que reveste o tabuleiro diretamente responsável pela barragem da água, e vigamento. Em alguns casos possuem um sistema de bombeamento, como na Figura 2.33. As peças fixas são os componentes que ficam embutidos no concreto e servem para guiar e alojar o tabuleiro e redistribuir para o concreto as cargas atuantes sobre a comporta. $\mathrm{O}$ mecanismo de manobras é o dispositivo diretamente responsável pela abertura e fechamento da comporta.

Algumas comportas dispensam o uso de mecanismo de manobras e são movimentadas pela pressão hidráulica, como as dos tipos setor, tambor e telhado. Os termos empregados na designação dos tipos de comportas são: basculante, cilíndrica, ensecadeira, gaveta, lagarta, mitra, rolante, segmento, setor, Stoney, tambor, telhado, vagão e visor (ABNT NBR 7259/82).
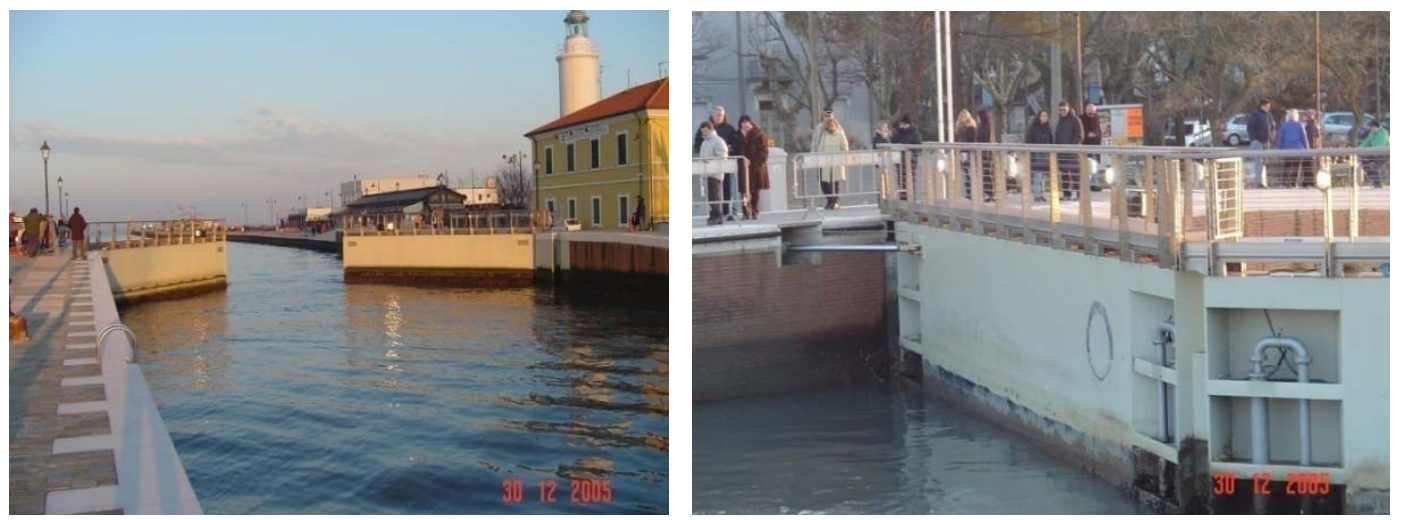

Figura 2.33 Comportas Vincianas em Cesenático (Itália) e Detalhe do Sistema de Bombeamento

No final do século XIX existia na cidade de Santos o desafio de promover a drenagem da região e prevenir possíveis inundações na cidade.

Os canais atravessam a ilha de São Vicente, cortando toda a cidade. O sistema de comportas (ver Figura 2.34) inclui bóias com sensores ultra-sônicos, que 
informam os níveis d'água a montante e a jusante, e auxiliam o seu controle. Para que as comportas funcionem de forma integrada, o sistema é dotado de no break, que garante a alimentação dos motores ininterruptamente, mesmo sem energia elétrica.

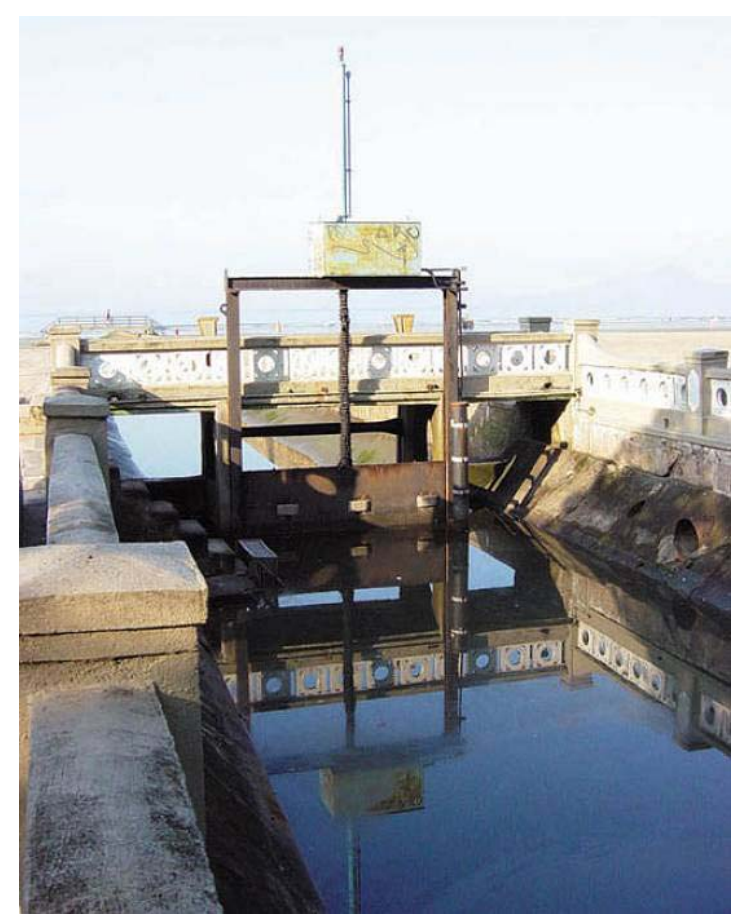

Figura 2.34 Comporta de um dos Canais de Santos, SP FONTE: www. novomilenio.inf.br/real/ed125 


\section{CAPÍTULO 3 OCORRÊNCIAS MUNDIAIS}

\subsection{CONSIDERAÇÕES GERAIS}

Significativa parcela da população mundial mora em torno da zona costeira, com muitas construções e instalações implantadas em cotas inferiores com relação à preamar média. Mesmo não considerando nenhuma alteração secular no nível médio do mar, ou mudança eustática, as cotas dessas estruturas não são adequadas para garantir a segurança da população, nos eventos de tempestades mais fortes, com efeitos de marés meteorológicas e astronômicas excepcionais.

A erosão das costas é um fenômeno que indica uma condição de vários processos em que é removido mais material da praia do quanto é suprido, devido à quebra do equilíbrio dinâmico original, sendo um dos principais problemas mundiais.

\subsection{HOLANDA}

Países Baixos faz jus ao nome que tem: o ponto culminante está a apenas 321 metros de altitude e $25 \%$ do território está abaixo do nível do mar. Tão abaixo que, ao aterrissar no aeroporto, em Amsterdã, o passageiro desembarca a 4,5 metros abaixo do nível do mar.

Banhada pelo Mar do Norte e por dois dos maiores rios da Europa - o Reno e o Mosa, a Holanda foi várias vezes inundada, transformando esses desafios em alta tecnologia hidráulica.

Em meados do século $\mathrm{XI}$, os primeiros diques começaram a surgir na Holanda para amenizar inundações provocadas pela maré alta e pelo 
transbordamento dos rios durante tempestades. Para escoar as águas, utilizavam-se os moinhos de vento, que bombeavam a água de volta para o mar, como Figura 3.1.

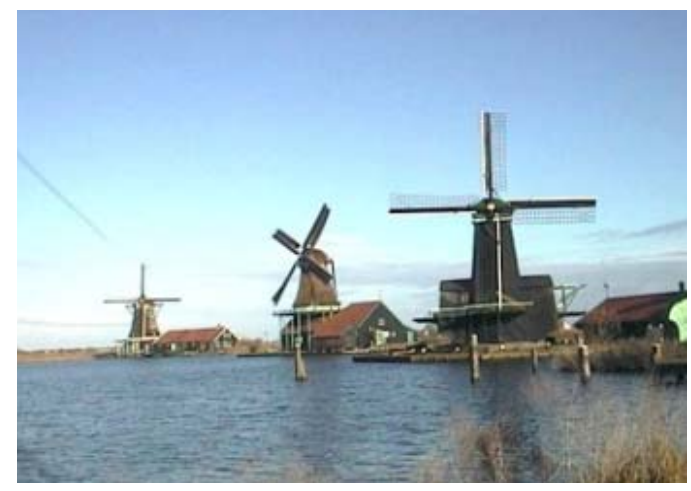

Figura 3.1 Moinhos de vento na Holanda

FONTE: www.fanpop.com/spots/the-netherlands/images

A partir do século XIX, eles deram mais um passo em direção ao mar, e lhes tomaram espaço construindo pôlderes cercados por diques. Alinhados paralelamente à costa e às margens do rio, os diques contiveram o avanço das águas. Estas, agora, são drenadas com o auxílio de bombas e canais transversais, formando as planícies de terra seca e fértil (ver Figura 3.2).

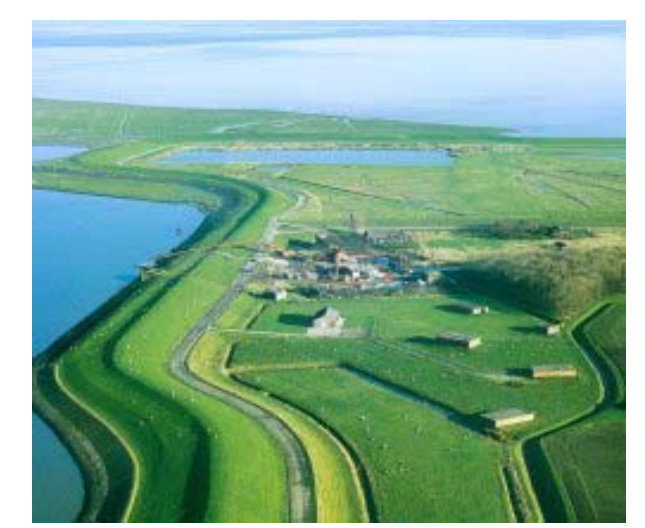

Figura 3.2 Diques formando Planícies

FONTE: www.fanpop.com/spots/the-netherlands/images

Determinou, então, a construção de grande número de eclusas, estações de bombeamento de água, diques e barreiras, entre os quais está o Dique do Fechamento ou Dique Afsluit (Figura 3.3), que separa as províncias da Holanda do Norte e da Frísia, com mais $30 \mathrm{~km}$ de extensão, e forma um mar pro interior - o lago ljssel. 


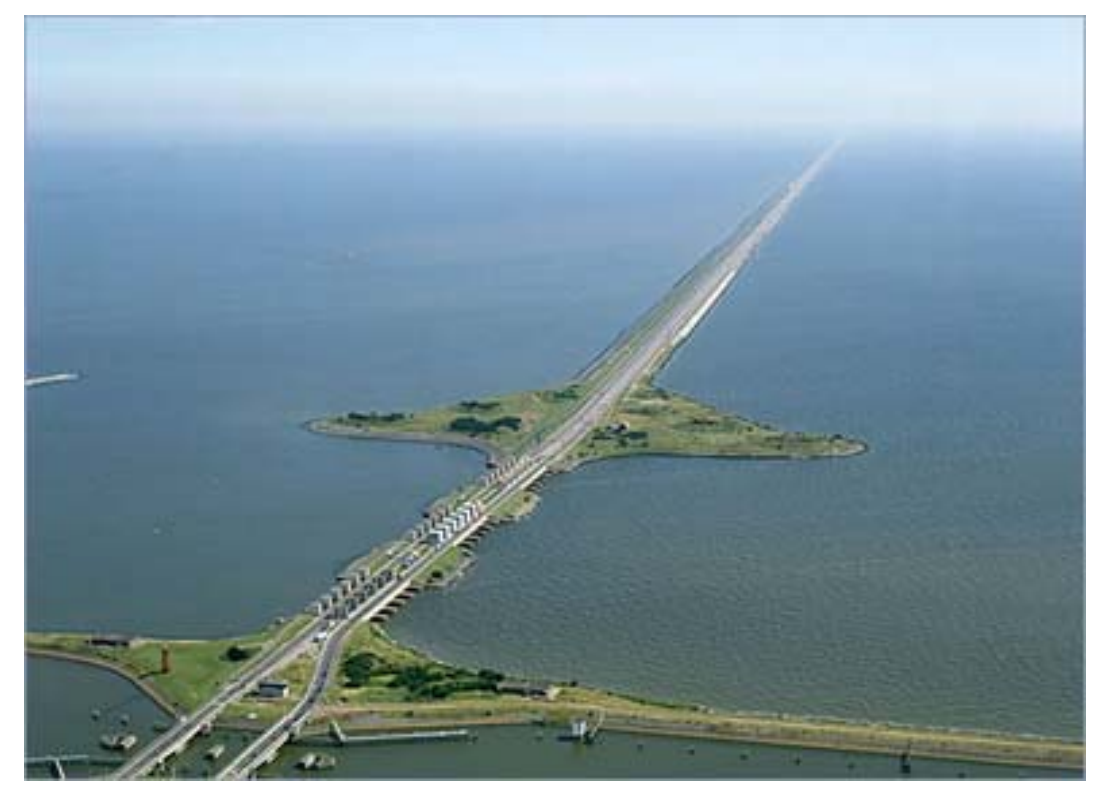

Figura 3.3 Dique Afsluit separando o Mar do Norte do Lago de ljssel FONTE: www.minbuza.nl/en/home

Atualmente, os Países Baixos possuem a mais avançada rede de diques no mundo. O principal desafio desta obra de engenharia é fazê-la resistir às tempestades marítimas, erosões e inundações.

Durante a inundação do mar do Norte em 1953, a brecha num dique dos Países Baixos, provocou a morte de 1.835 pessoas, forçando a evacuação de outras 70.000 pessoas, sendo que cerca de 4.500 edificações foram destruídas. Para evitar que uma catástrofe assim se repita, um ambicioso projeto foi lançado para proteção da costa da região sudoeste na província de Zeeland: o Projeto Delta. As obras, concluídas em 1997, levaram 30 anos para serem construídas e hoje, elas são referência de obras de defesa costeira.

A obra mais destacada desse projeto é a Oosterscheldekering (ver Figura 3.4), finalizada em 1987, protege a região de Zeeland com mais de 3 quilômetros de extensão de dique. A estrutura é composta por 65 pilares de concreto, com alturas entre 30 e 40 metros, pesando 18.000 toneladas cada. Entre os pilares, as 62 comportas de aço fecham as passagens, com cerca de 50 metros de comprimento, pesando, em média, 400 toneladas cada. 

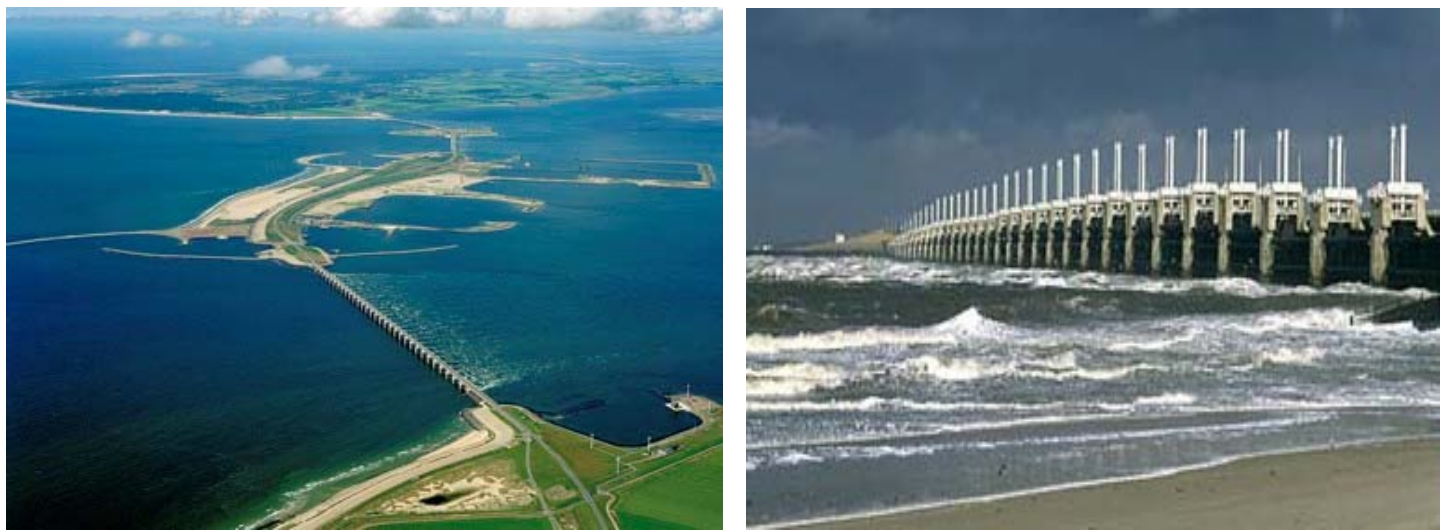

Figura 3.4 Dique Oosterscheldekering FONTE: www. deltawerken.com

Quando as ondulações atingem 3 metros acima da média do nível do mar, um alarme é disparado e as comportas hidráulicas são abaixadas por computadores, gastando cerca de 30 minutos, fechando a passagem. Suas comportas já foram abaixadas mais de 20 vezes. Cada comporta foi construída para agüentar os piores ataques do violento Mar do Norte, observada na Figura 3.5.
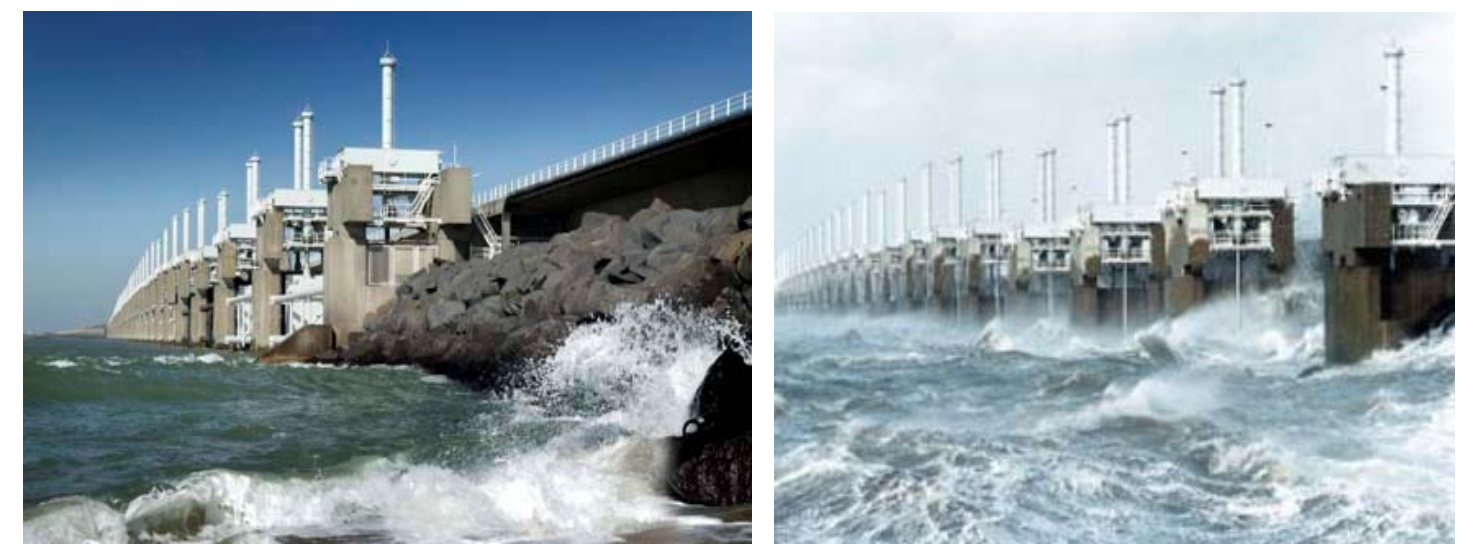

Figura 3.5 Violento Mar do Norte FONTE: www.deltawerken.com

O dique inteiro é suportado por 5 milhões de toneladas de pedras colocadas na base dos pilares por um guindaste especial.

Outra obra de destaque é a Maeslantkering, cujo principal objetivo foi a melhoria da segurança contra inundações no Porto de Roterdã nas cidades do entorno e nas áreas agrícolas.

A novidade desse projeto é que a construção da barreira pôde ser feita em condições secas. Partes vitais da barreira não precisam ficar alocadas debaixo da 
água, e a manutenção da barreira é relativamente fácil, devido às docas secas. Evidentemente, não há quase nenhum inconveniente para a passagem dos navios.

A construção da barragem começou em 1991. O projeto contém dois grandes portões flutuantes, em ambos os lados da hidrovia. Primeiro, as docas secas foram construídas nas duas margens e uma soleira foi construída no fundo da passagem. Em seguida, os dois portões de aço foram construídos com 22 metros de altura e 210 metros de comprimento cada. Treliças, também de aço, com 237 metros de comprimento foram soldadas para a sustentação dos portões (ver Figura 3.6).

No ano de 1997, após seis anos de construção, a barreira Maeslantkering foi inaugurada. Toda a estrutura está ligada a um computador sensível aos dados de clima e nível do mar. Em condições climáticas normais, as duas portas estão bem protegidas em suas docas secas, e sem nenhum inconveniente para a passagem dos navios. Mas quando uma tempestade atinge 3 metros acima do nível normal do mar, está previsto que, em Roterdã, a barreira feche automaticamente seus portões.
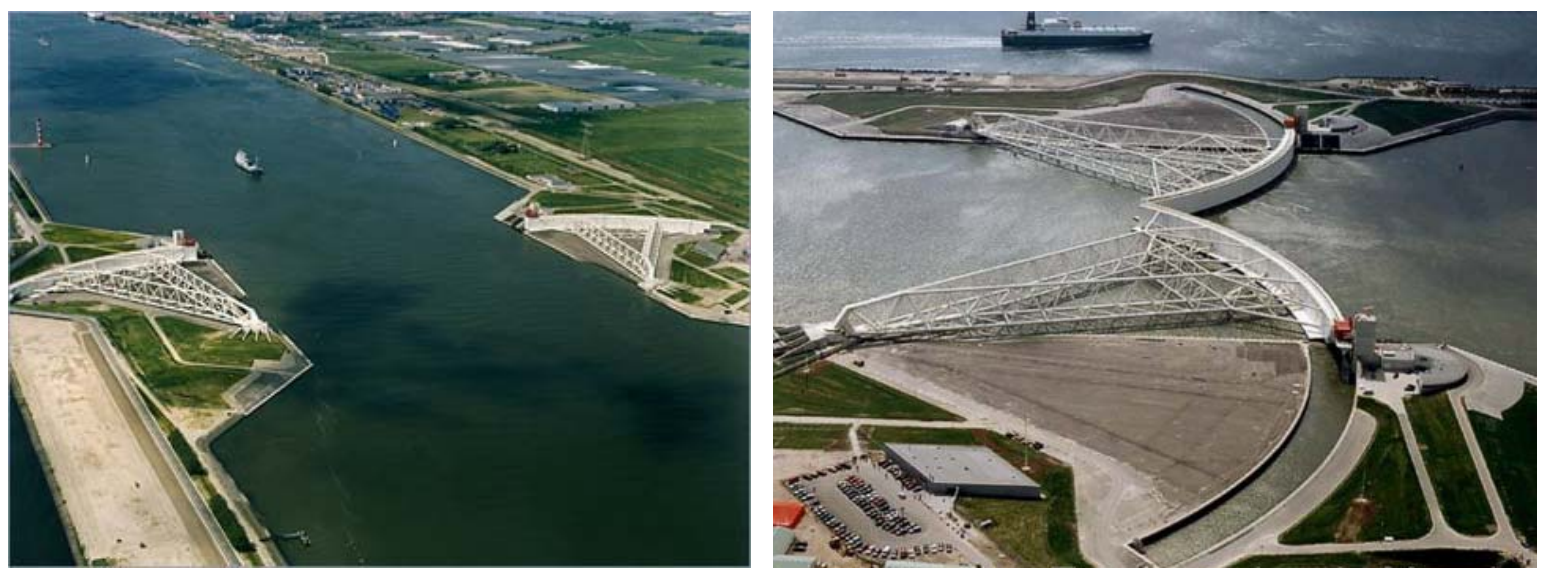

Figura 3.6 Dique Maeslantkering FONTE: www.minbuza.nl/en/home, www.keringhuis.nl

Nos seus primeiros dez anos de funcionamento, a barreira nunca foi fechada. Porém, pela primeira vez, em 2007, a estrutura foi utilizada devido a uma grande tempestade, com níveis excepcionais.

Uma análise de custo-benefício, associada com as questões ambientais envolvidas tem sido constantemente utilizada na Holanda para nortear a implantação de diques desde as severas inundações de 1953. 


\subsection{ITÁLIA}

No começo do século 20, a cidade de Veneza sofria com as inundações 10 vezes por ano, em média. Atualmente, a água inunda a Praça São Marcos cerca de 100 vezes ao ano.

A decisão de proteger Veneza das marés mais altas foi tomada em 1966, quando uma grande inundação deixou mais de 5 mil pessoas desabrigadas. Depois de vários transtornos com as enchentes, em 1973, o governo italiano declarou que Veneza era um caso de preocupação nacional. Mesmo assim, foram necessários mais 30 anos de debate até que a obra contra as inundações tivesse início.

Em setembro de 2003, iniciou-se uma gigantesca obra de Engenharia, para prevenir as inundações da cidade: o Projeto Moisés, com término previsto para o ano de 2010.

O projeto é composto por um sistema amplo de comportas, instalado nas três entradas para a laguna de Veneza: Lido, Chioggia e Malamocco (ver Figura 3.7).

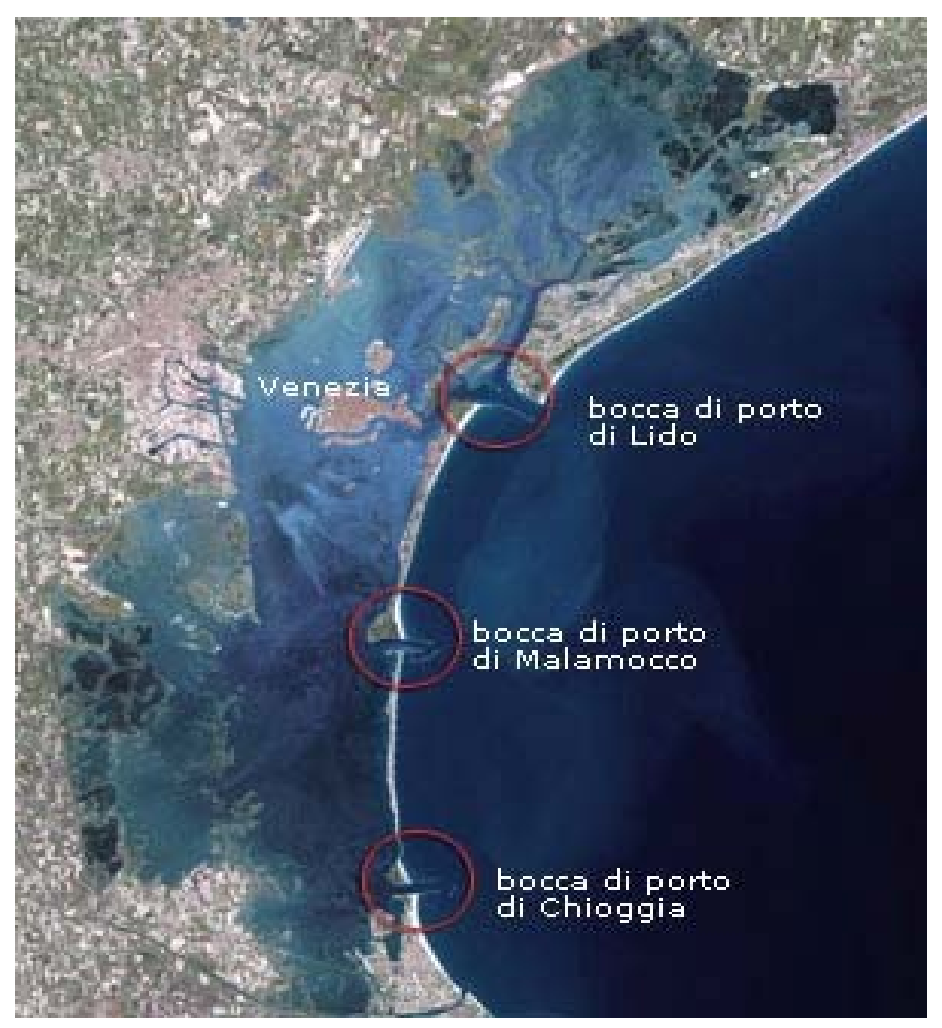

Figura 3.7 Entradas para a Laguna de Veneza FONTE: www.salve.it/it/soluzioni/f_acquealte 
A primeira fase acompanhou a remoção de 3,8 milhões de metros cúbicos de terra do leito da lagoa na boca de suas três entradas. Isso está sendo substituído por 9 milhões de toneladas de pedra e concreto para oferecer uma fundação firme para fixar as 78 comportas de aço. Cada uma com cerca de 20 metros de largura, 30 metros de altura e pesando 300 toneladas. Abaixo, na Figura 3.8, está a entrada de Malamocco.

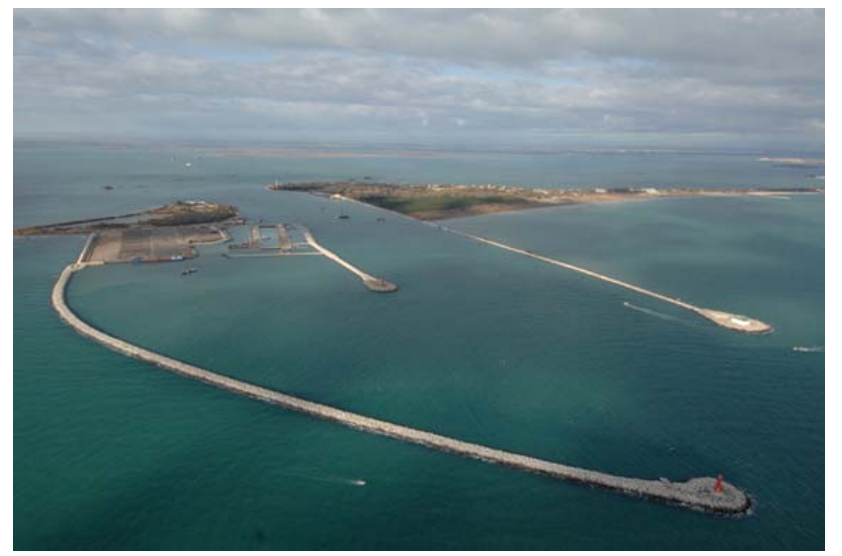

Figura 3.8 Entrada de Malamocco

FONTE: www.salve.it/it/soluzioni/f_acquealte

Quando as comportas não estiverem sendo usadas, permanecerão submersas, cheias de água, no fundo da laguna. Sob a ameaça de marés altas (superiores a $1 \mathrm{~m}$ ), as válvulas hidráulicas serão abertas com um simples aperto de botão, e um sistema hidráulico os encherá de ar para elevá-los até a superfície, permitindo que as comportas fiquem em posição para represar a água. A esquematização seqüencial deste processo está apresentada na Figura 3.9. As comportas são projetadas para suportar marés até 3 metros acima dos máximos registrados.

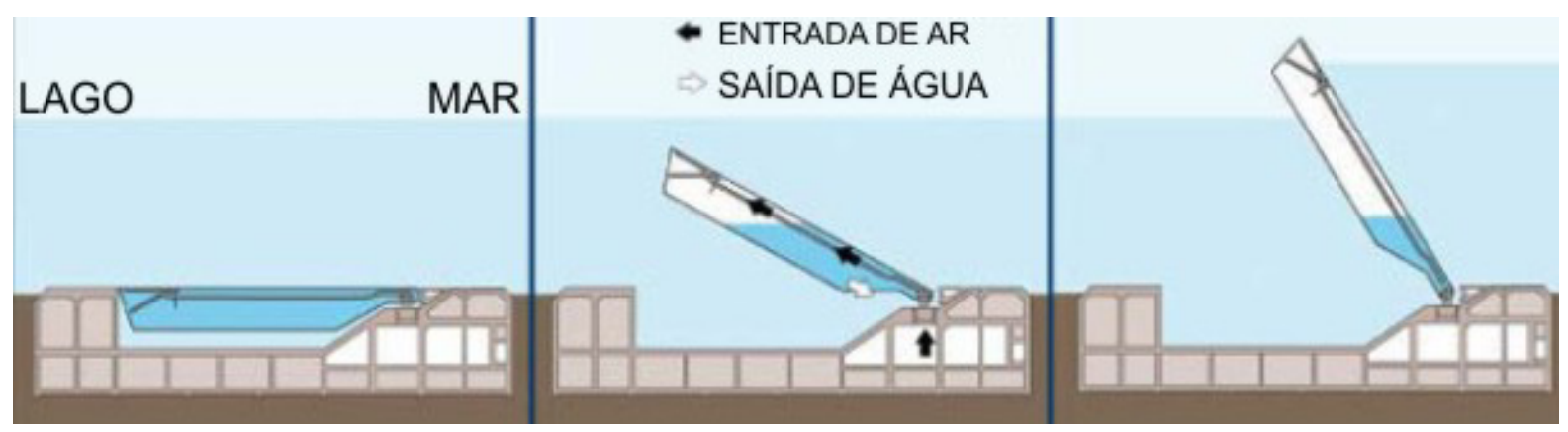

Figura 3.9 Ilustração do movimento da Comporta FONTE: www.salve.it/it/soluzioni/f_acquealte 
Na verdade não é só a subida do nível do mar que a cidade de Veneza tem que lutar. A cidade está afundando como um resultado da subsidência causada por décadas de extração subterrânea, e pela perfuração de gás metano. Esta combinação significa que Veneza, efetivamente, afundou 23 centímetros no século passado (Nick Squires).

Também na Itália, Cesenático é uma cidade portuária com cerca de 20.000 pessoas, localizada cerca de $30 \mathrm{~km}$ ao sul de Ravena, na costa do Mar Adriático. $\mathrm{O}$ "canal-porto" da região foi construído em 1500, depois de ter sido desenhado por Leonardo da Vinci, como parte dos planos políticos para fortalecer a ligação com a cidade vizinha de Cesena.

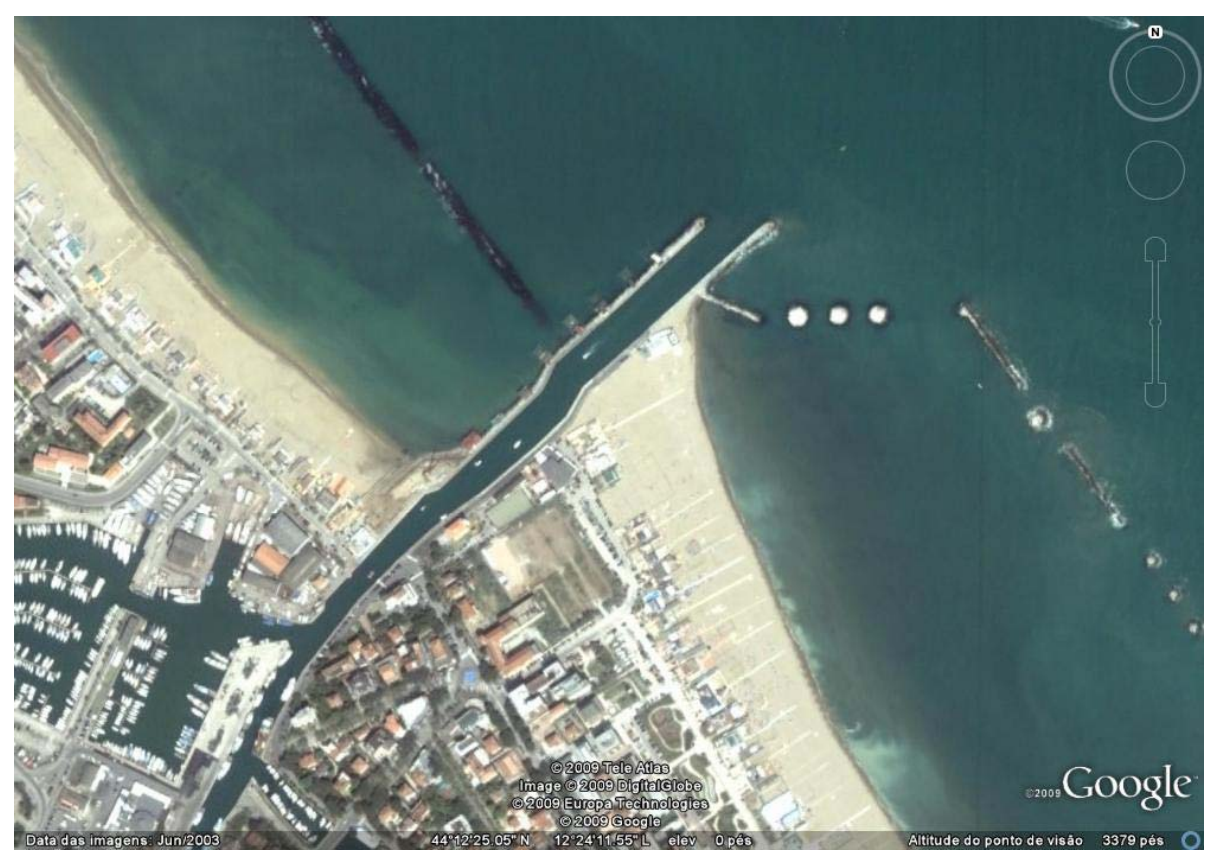

Figura 3.10 Região Cesenático FONTE: Google Earth

Nessa região, existem múltiplas obras de defesa dos litorais (ver Figuras $3.10,3.11,3.12$ ), que modificam todo o transporte de sedimento, além de comportas no canal de acesso em Cesenático. À medida que se engorda uma área, as áreas adjacentes são submetidas a efeitos erosivos, pois ocorre uma retenção do transporte de sedimentos litorâneo longitudinal de areias a barlamar, em detrimento do suprimento de areias a sotamar, conforme claramente observa-se na Figura 3.10, comparando-se a linha de costa à direita e à esquerda dos molhes, respectivamente.

Na mesma Figura 3.10, pode-se observar que os quebra-mares emersos foram implantados do lado direito (ver também Figura 3.12), e provocaram uma 
intensa retenção de areia, além de não permitirem uma adequada renovação das águas; enquanto que do lado esquerdo, visando mitigar este último problema, foram implantados quebra-mares semi-submersos (emergem entre a baixa-mar e a meiamaré). Deste lado também há espigões de praia (ver Figura 3.11). Apenas neste estudo, elencam-se as seguintes obras de defesa costeira: molhes guias-correntes, quebra-mares emersos, quebra-mares imersos, espigões de praia, duna artificial e comportas.

Deste modo, fica evidente como a região em estudo precisa ser muito bem examinada e analisada, antes da execução de qualquer obra marítima.

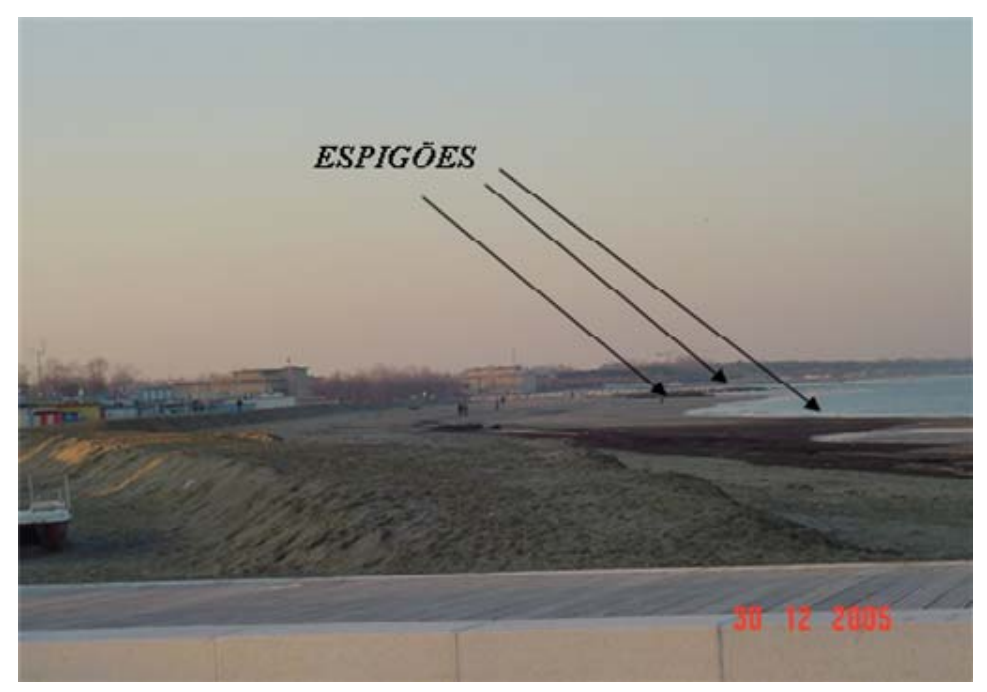

Figura 3.11 Espigões ao fundo (Cesenatico / Itália)

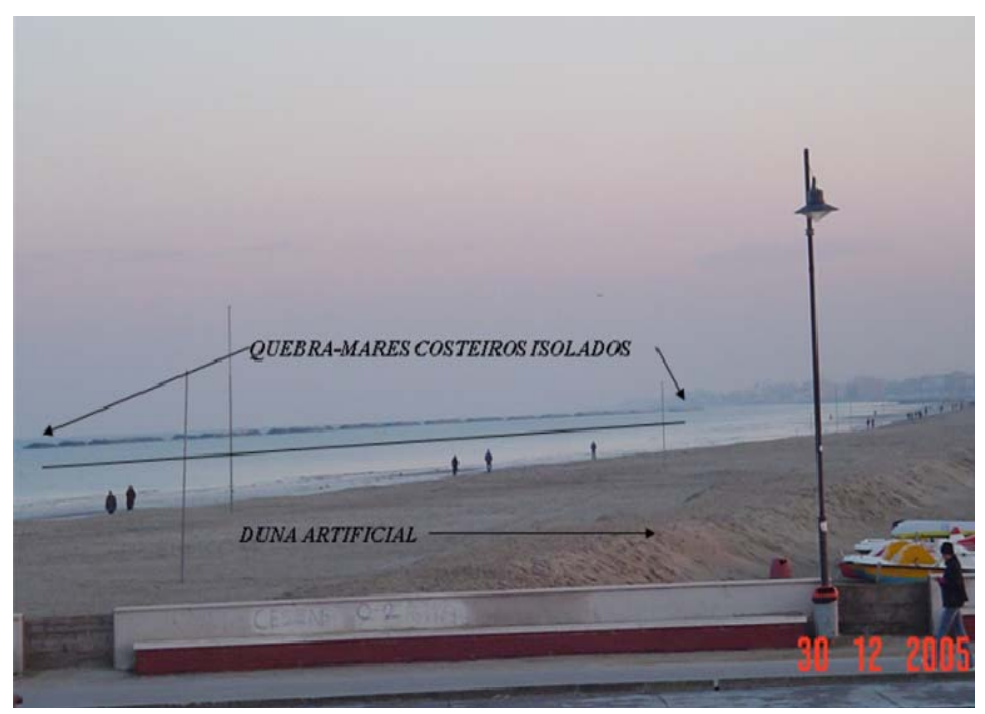

Figura 3.12 Múltiplas Obras de Proteção (Cesenatico / Itália) 


\subsection{INGLATERRA}

No ano de 1953, uma devastadora inundação atingiu a costa leste de Londres e o estuário do rio Tâmisa, na Inglaterra, fazendo centenas de vítimas. Na seqüência das inundações ocorridas, o Governo do Reino Unido iniciou a construção de uma grande obra de defesa contra inundações. Trata-se da Barreira do Rio Tâmisa, inaugurada oficialmente em 1982 (ver Figuras 3.13 e 3.14).

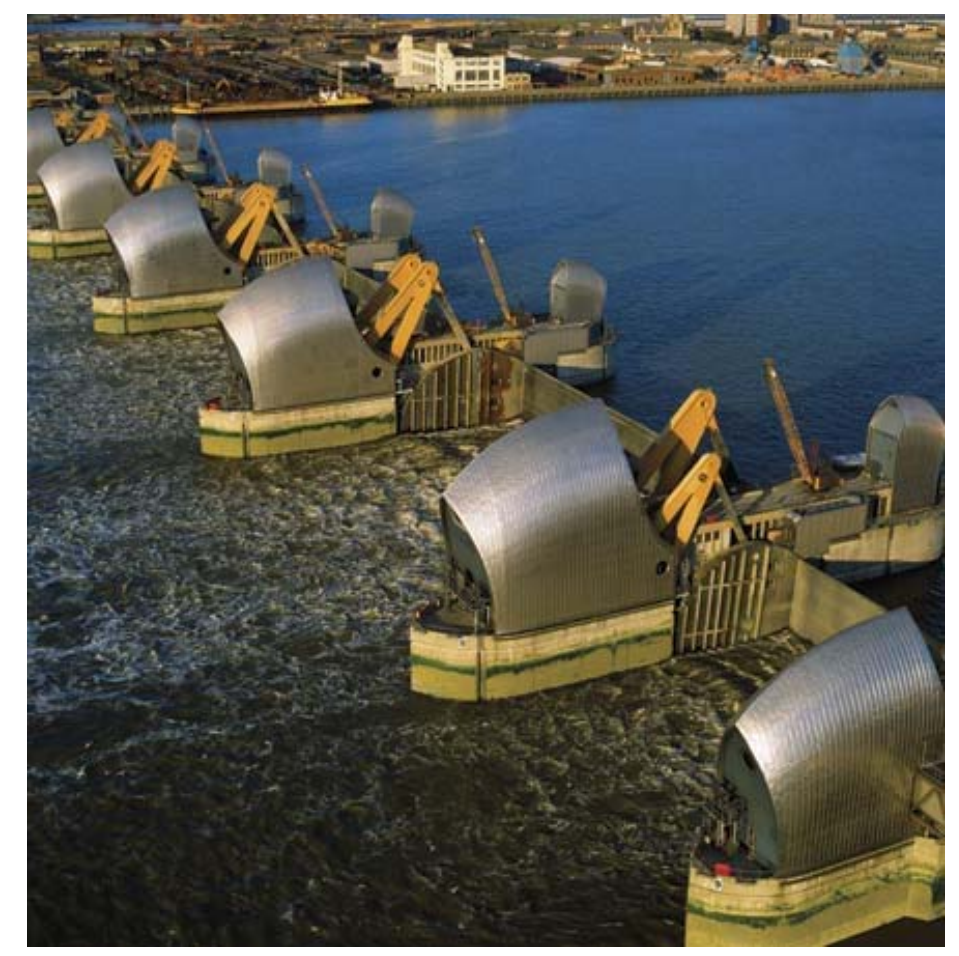

Figura 3.13 Barreira do Rio Tâmisa

FONTE: cache.eb.com/eb/image

Inicialmente, a barreira foi construída para impedir a inundação de Londres até o ano de 2030. Durante os últimos 20 anos, para evitar estas inundações, as comportas da barreira foram elevadas 25 vezes, principalmente como medida de precaução. 


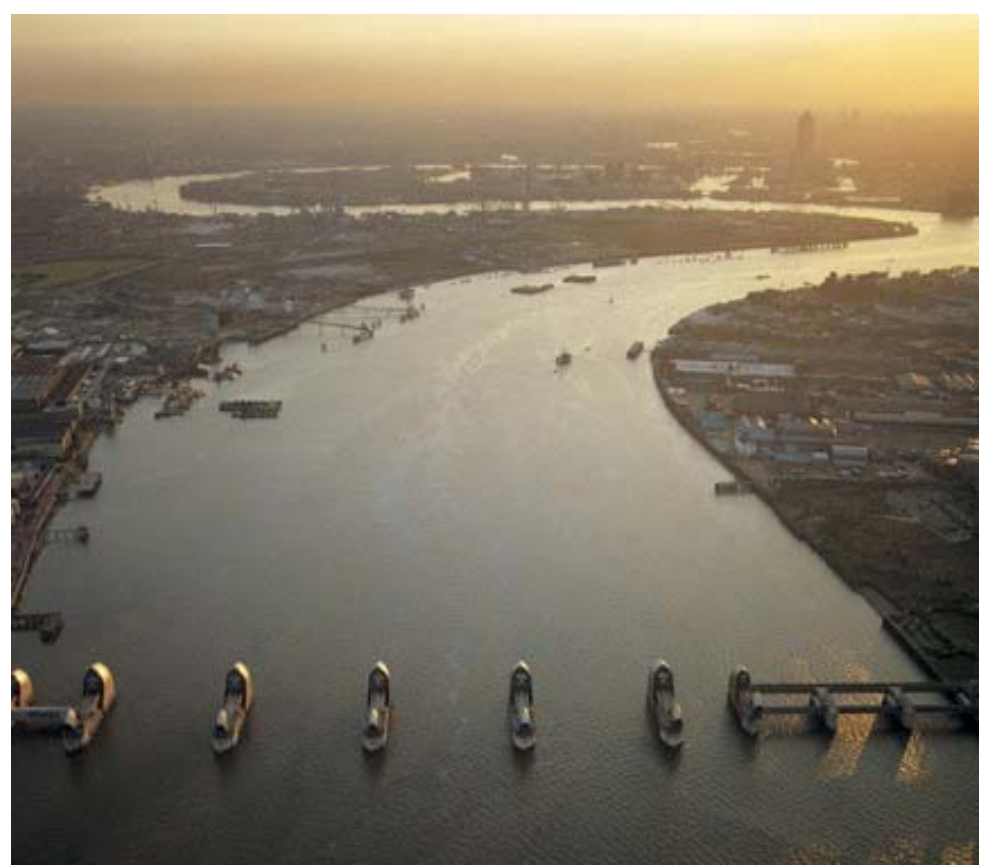

Figura 3.14 Barreira do rio Tâmisa

FONTE: www.bbc.co.uk/london/content/image_galleries/thames_barrier_gallery

A estrutura abrange 520 metros de comprimento, cruzando todo o rio Tâmisa, e é constituída por uma série de 10 comportas posicionadas de uma margem a outra do rio, separadas por 9 cais.

A barreira é composta por 4 comportas centrais de 61 metros de largura e uma altura equivalente a 5 andares, mais 6 comportas laterais. Numa lateral do canal, 2 comportas interligadas com 31 metros de largura cada, e na outra margem, 4 comportas com a mesma largura. Para cada comporta foi utilizado cerca de 9.600 toneladas de aço. E meio milhão de toneladas de concreto foi usado para a construção dos cais. As comportas são movidas por energia hidráulica, alimentadas eletricamente.

Cada comporta tem uma face curva, que se situa em câmaras no fundo do rio, quando a barragem está totalmente aberta. Quando o sinal de alerta é dado, os portões giram $90^{\circ}$, e ficam numa posição fechada, bloqueando o caminho das marés, em menos de 30 minutos. A esquematização seqüencial deste processo está apresentada nas Figuras 3.15 e 3.16 . 


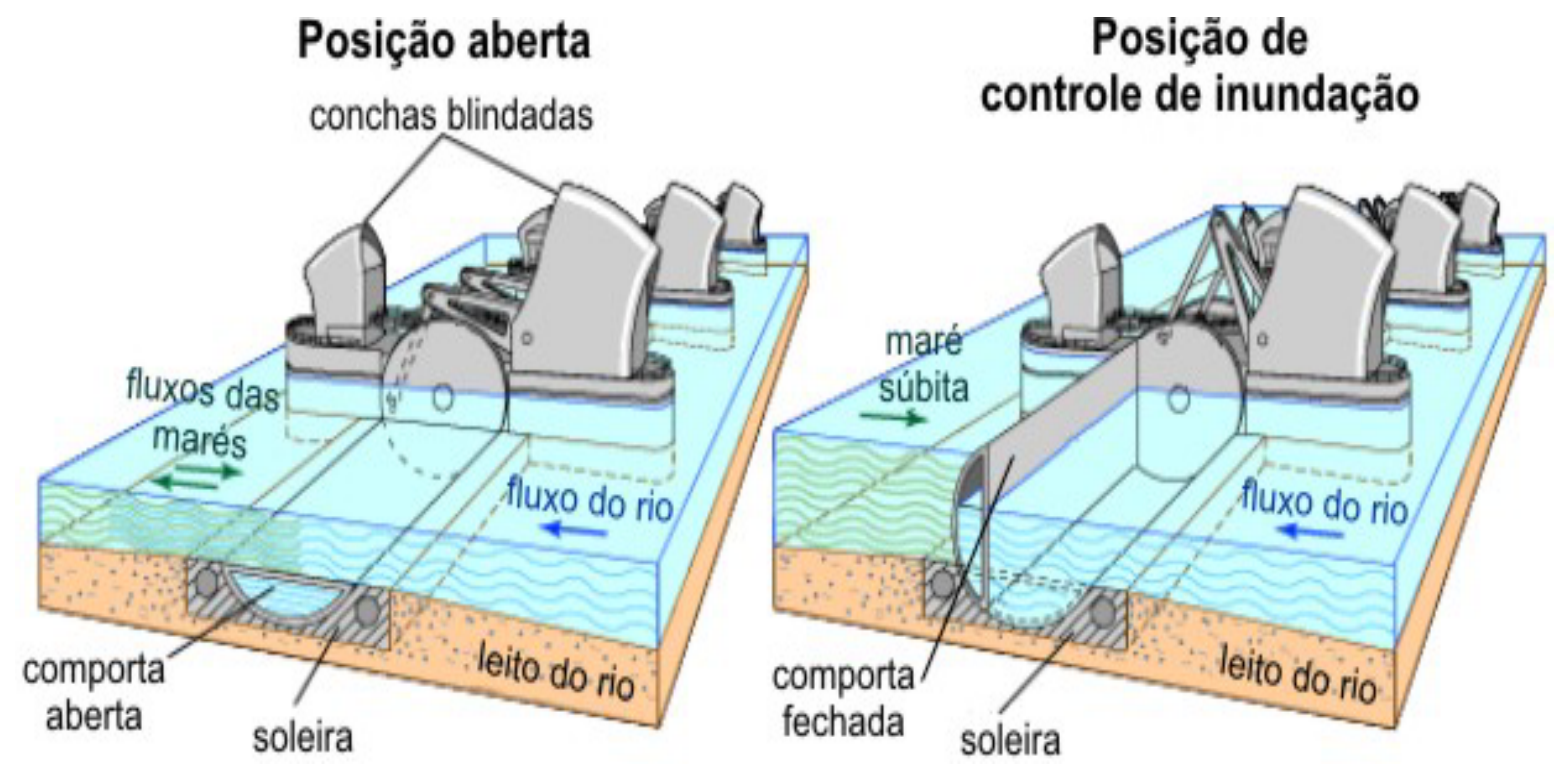

Figura 3.15 llustração do funcionamento da Comporta no Rio Tâmisa FONTE: cache.eb.com/eb/image

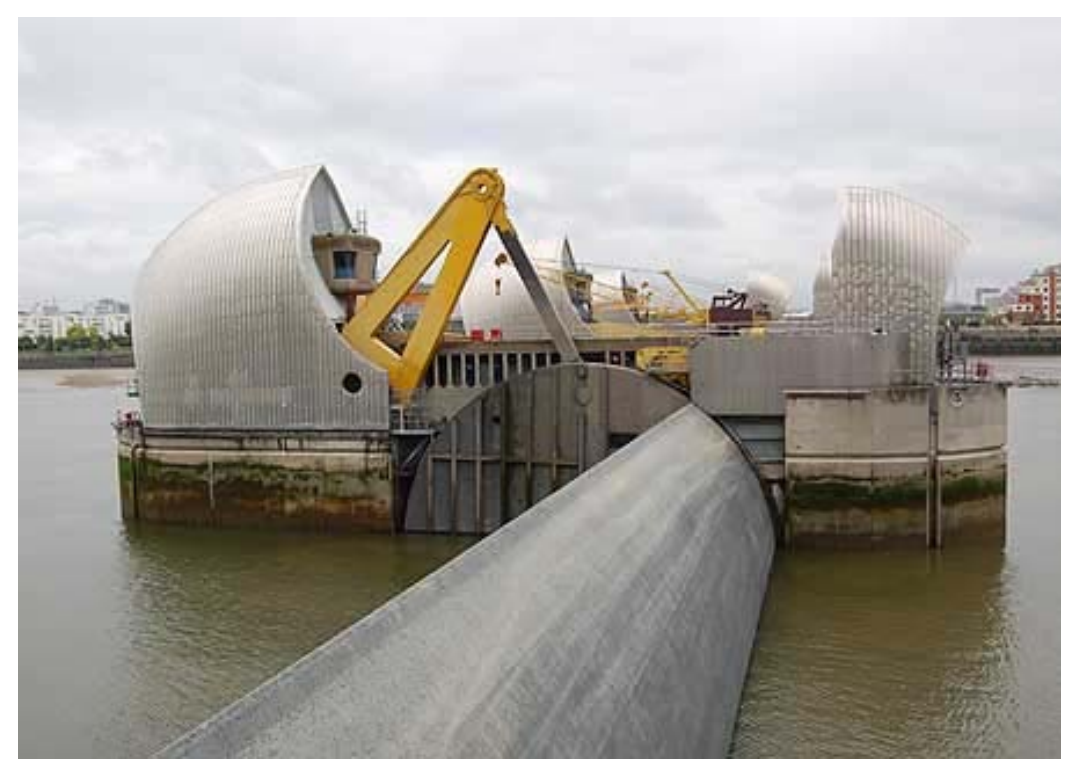

Figura 3.16 Detalhe da Comporta no Rio Tâmisa

FONTE: www.bbc.co.uk/london/content/image_galleries/thames_barrier_gallery

A cada século, o nível das águas do rio Tâmisa cresce uma média de 0,9 metros. O Estuário do Tâmisa é uma área onde o risco de inundações é particularmente elevado e esta região está cada vez mais exposta ao risco de inundações devido ao aumento médio do nível do mar, ao aumento da precipitação e das marés, e a um maior número e intensidade das tempestades. Também vale lembrar, que a parte sudoeste da Inglaterra está submergindo devido à pequena subsidência local. Na cidade de Londres, a maior parte da água que se utiliza é 
extraída de um aqüífero de cal, uma fonte importante de água subterrânea. Este fato provoca uma dessecação progressiva das placas de argila que se encontram no subsolo da região.

\subsection{ESTADOS UNIDOS}

Galveston é o nome do paredão, construído na cidade de Galveston, nos Estados Unidos. Ele foi planejado em 1902, após um grande furacão (Furacão de Galveston, 1900) que devastou a região, no Estado do Texas, a fim de proteger a área de futuros desastres.

Os estragos do furacão foram realmente significativos, pois a ilha está em cotas relativamente baixas e planas. Mais de 3.600 casas foram destruídas, e cerca de 8.000 pessoas morreram.

A construção da obra começou em setembro de 1902, e o trecho inicial foi concluído em 1904. Do ano de 1904 ao ano de 1963, o paredão com 5,30 km de extensão já construídos, foi acrescido de mais 10,70 km. A estrutura, portanto, totaliza 16 quilômetros de comprimento, com 5,20 metros de altura e 4,90 metros de espessura, conforme ilustrado na Figuras 3.17 e 3.18 .
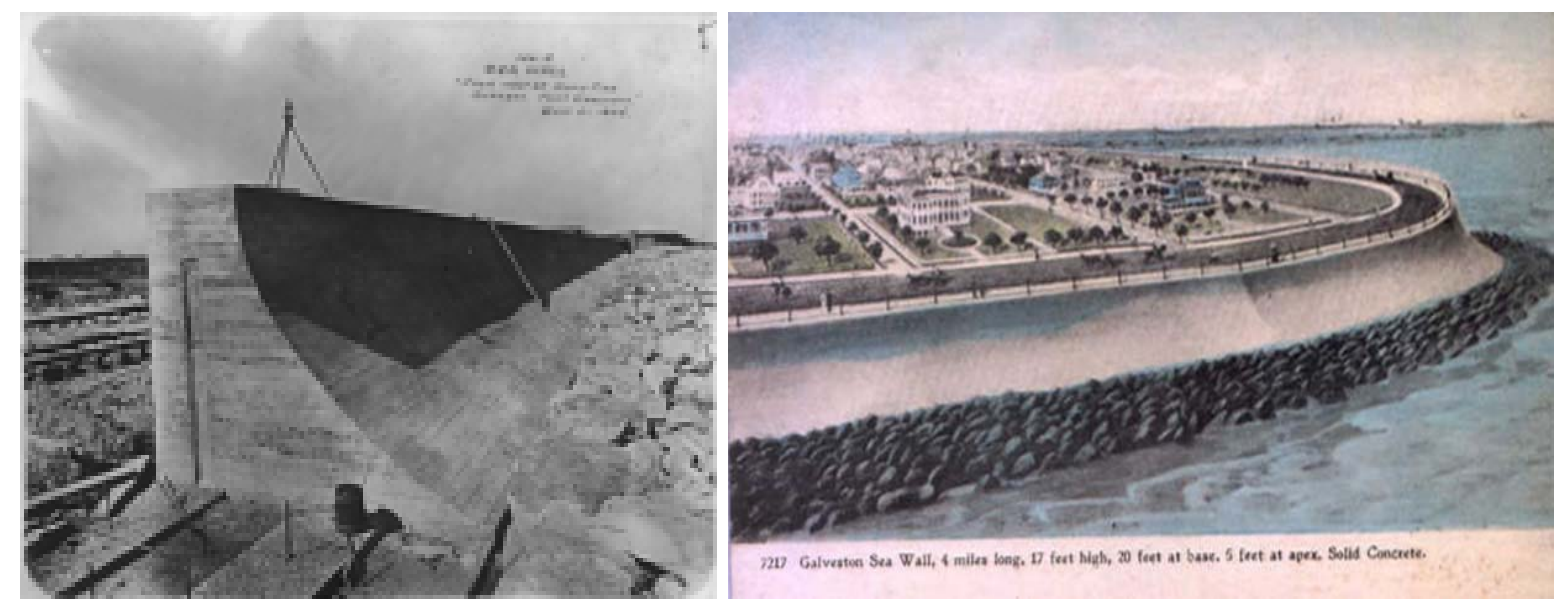

Figura 3.17 Paredão de Galveston nos Estados Unidos FONTE: nachofoto.com 
Apesar do muro nunca ter sido galgado por uma onda, sua estrutura já foi bastante danificada pela ação das tempestades excepcionais.

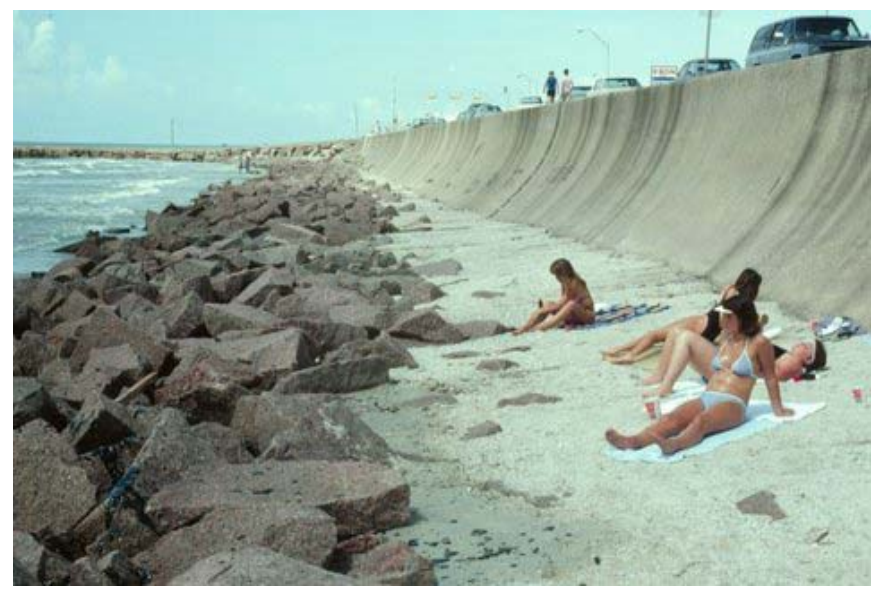

Figura 3.18 Detalhe da estrutura num dia de Sol FONTE: nachofoto.com 


\section{CAPÍTULO 4 \\ ESTUDO DE CASO \\ PRAIA DE MASSAGUAÇU}

\subsection{INTRODUÇÃO}

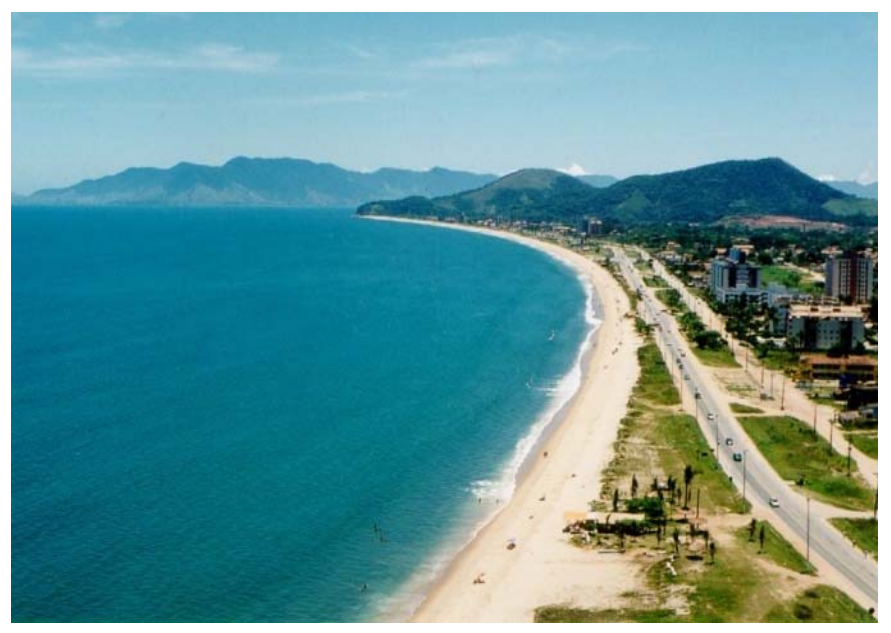

Figura 4.1 Praia de Massaguaçu

Em tupi-guarani, grande massa d'água, ou seja, praia de ondas fortes.

FONTE: wWw.litoralvirtual.com.br

O caso a ser estudado está situado na Rodovia Dr. Manuel Hyppolito Rego SP-55 (pertencente ao DER / SP - Departamento de Estradas de Rodagem do Estado de São Paulo) entre os quilômetros 89 e 91 (LE) - na Praia de Massaguaçu, na cidade de Caraguatatuba. Nesse local existe uma instabilidade de talude do aterro, devido a erosões causadas pelas ondas do mar, agravada pelas saídas da drenagem superficial da rodovia. O objetivo deste estudo é descrever as características e particularidades do local, as possíveis causas desses impactos e as alternativas de soluções adotadas e estudadas para a execução dos projetos. 

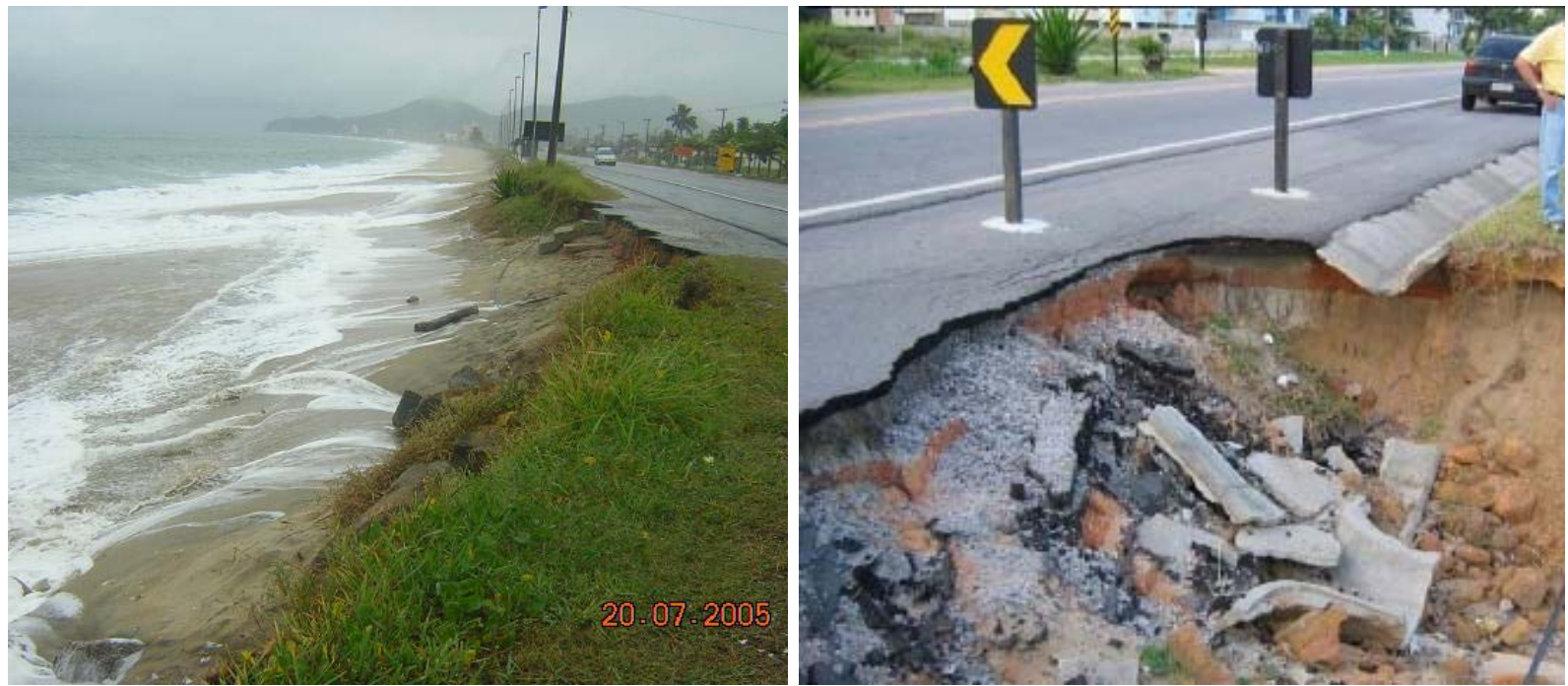

Figura 4.2 Vista Geral do Trecho Afetado

O trecho afetado (Figura 4.2) tem cerca de 450 metros de extensão ao longo da rodovia e apresenta uma cota de 5 metros acima do nível do mar (zero IBGE), com traçado retilíneo. As erosões apresentam-se em diversos graus sendo que as mais críticas já atingem o acostamento da rodovia, fazendo um cenário de risco para a população e usuários da rodovia. Existem também, nesta mesma praia, pontos localizados de erosões junto às saídas da drenagem da pista, ver Figura 4.3.
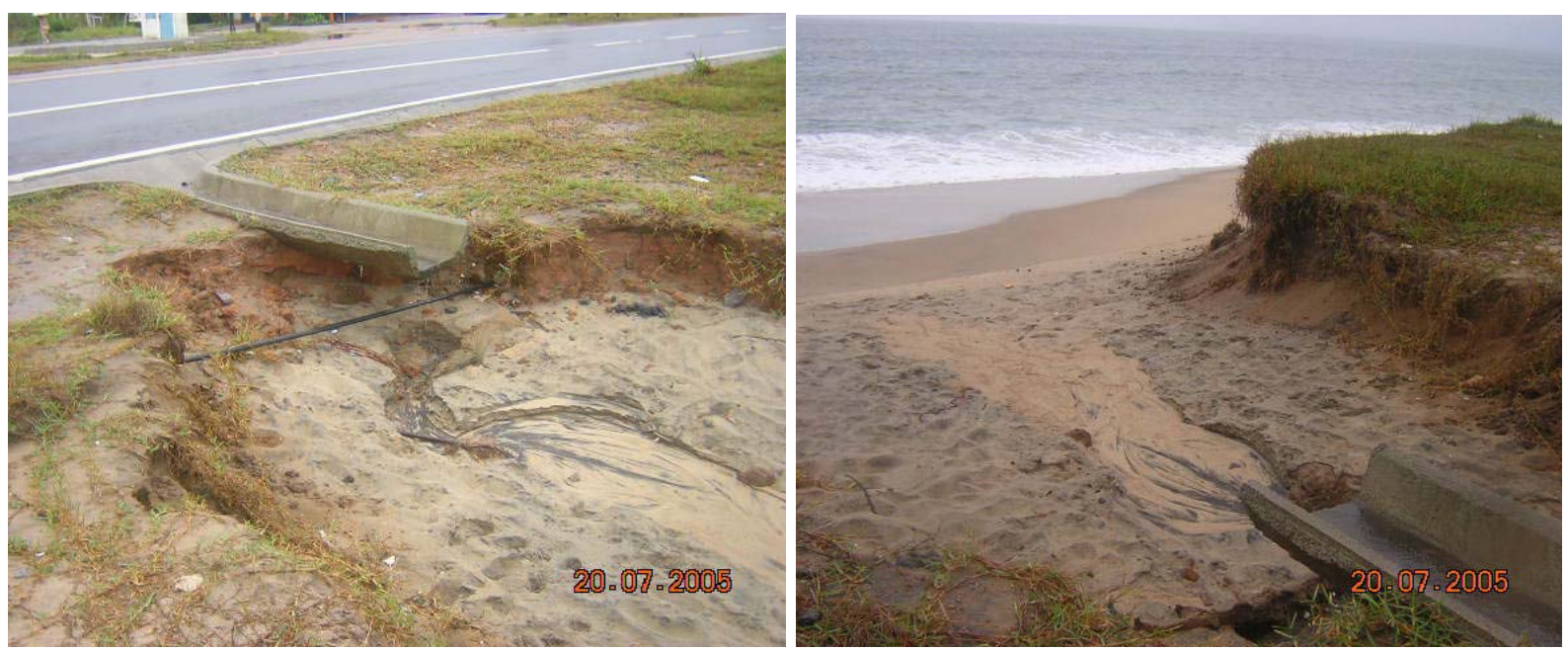

Figura 4.3 Erosão junto à Saída de Drenagem

A instabilidade junto à rodovia foi causada por erosões devido à ação das ondas do mar e saída de drenagem de águas pluviais, solapando a base do aterro e desencadeando escorregamentos, que chegaram a afetar até o acostamento da rodovia, ilustrado na Figura 4.4, trazendo inúmeros prejuízos para população. 

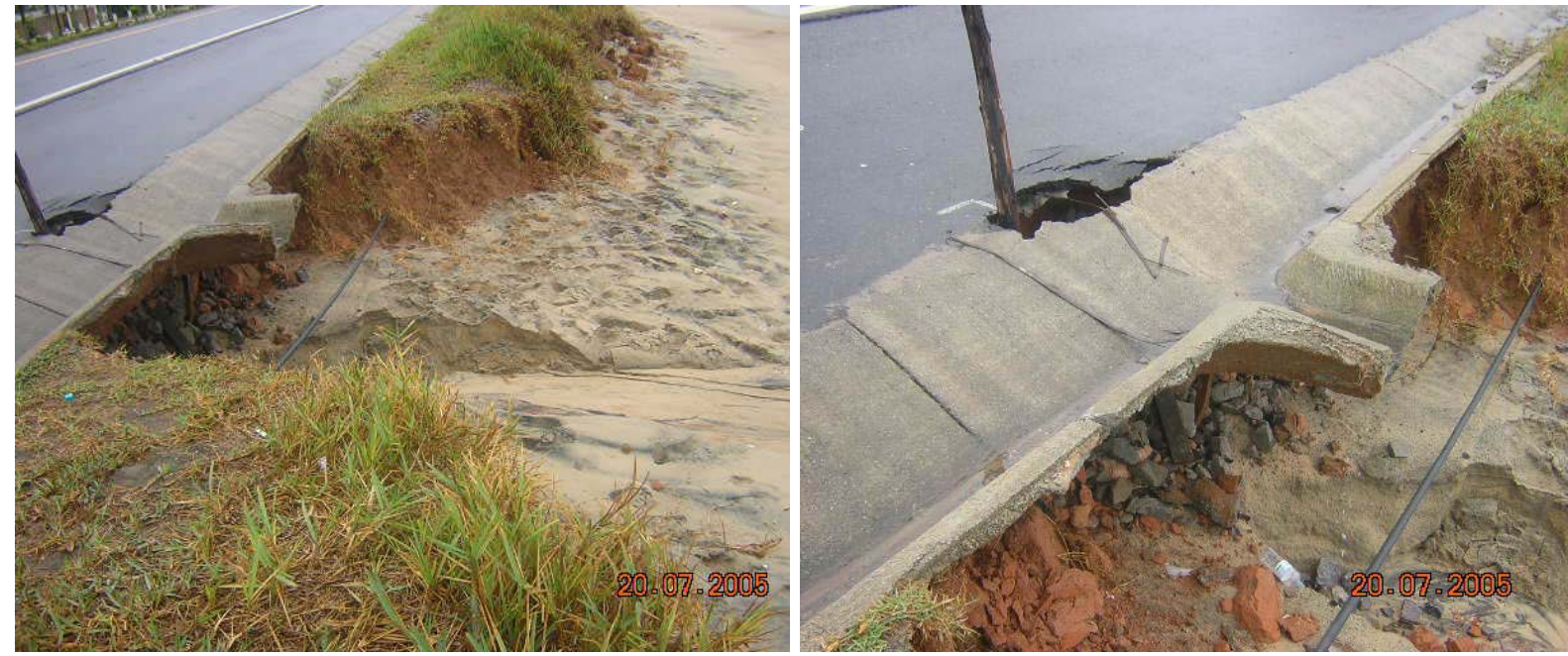

Figura 4.4 Erosão no Acostamento da Rodovia

\subsection{ESTUDO DE DADOS E PROJETO DE CONTENÇÃO}

Na concepção geral para as medidas de proteção e contenção da erosão na Rodovia Dr. Manuel Hyppolito Rego - SP-55 (entre os km 89 a 91 (LE), na Praia de Massaguaçu) foi feito, inicialmente em 2005, o levantamento das informações disponíveis, abrangendo: seções topográficas de todo o trecho atingido, características geológico-geotécnicas do local, informações gerais acerca de marés, correntes e ondas, e estruturas utilizadas anteriormente na proteção de áreas próximas, sempre consultando bibliografias consagradas de engenharia costeira.

\subsubsection{Dados}

O mapeamento geológico-geotécnico do local constatou a existência de material argiloso compactado na execução do aterro da estrada sobre a praia. Também foi empregado enrocamento com pedras de grande diâmetro (acima de 50 $\mathrm{cm}$ ), para a proteção da base do aterro. Essa proteção não foi eficiente devido à ausência de camada de transição com graduação de pedras na faixa granulométrica (filtro) que evitaria o solapamento junto ao enrocamento. 
Segundo o banco nacional de dados oceanográficos da Diretoria de Hidrografia e Navegação (DHN) e o projeto básico do porto piloto de São Sebastião da TRANSESP (Pesquisa e Planejamento de Transportes do Estado de São Paulo S.A), os dados de marés, máxima e mínima, e de ondas frontais à costa, com ângulo de $150^{\circ}$, estão apresentados nas Tabelas 4.1 e 4.2 abaixo.

Tabela 4.1 Marés de Máxima e de Mínima

\begin{tabular}{|c|c|c|}
\hline Marés & $\begin{array}{c}\text { DHN - astronômica } \\
\text { (tábua de maré - agosto 2005) }\end{array}$ & $\begin{array}{c}\text { Porto Piloto de São Sebastião } \\
\text { (novembro 1978 - cota) }\end{array}$ \\
\hline Máxima $(\mathrm{m})$ & 1,20 & 2,06 \\
\hline Mínima $(\mathrm{m})$ & $-0,20$ & $-0,04$ \\
\hline
\end{tabular}

Tabela 4.2 Ondas Frontais à Costa

\begin{tabular}{|c|c|c|c|c|c|c|}
\hline Ondas $(\mathrm{m})$ & 1,0 & 1,0 a 2,0 & 2,0 a 3,0 & 3,0 a 4,0 & 4,0 a 5,0 & 5,0 \\
\hline (\% do tempo) & 2,97 & 3,83 & 0,96 & 0,14 & 0,10 & - \\
\hline
\end{tabular}

Para a definição da estrutura a ser utilizada na proteção do talude considerou-se que, no processo de erosão costeira, as praias tendem a atingir uma rampa de equilíbrio. Esta rampa depende fundamentalmente das solicitações existentes, ou seja, das ondas e marés, e da granulometria da areia da praia. A inclinação de equilíbrio existente na praia estudada é da ordem de $1 \mathrm{~V}: 10 \mathrm{H}$, e está coerente e dentro dos limites considerados usuais no Manual de Engenharia Costeira - Coastal Engineering Manual (2002).

Outro elemento observado nos levantamentos efetuados é que grande parte dos inícios das rampas existentes nas praias está próximo da cota 1,2 m acima do nível do mar, valor coerente com a cota da maré astronômica máxima obtida da DHN (Diretoria de Hidrografia e Navegação).

Através das inspeções das estruturas existentes na região estudada, considerando os aspectos construtivos e logísticos, concluiu-se ser conveniente a utilização de muros de pedra argamassada, com cota de topo igual à cota da rodovia existente. Este tipo de estrutura é bastante resistente, considerando as solicitações usuais, porém, como em toda e qualquer estrutura, existe a necessidade de prever limpeza e manutenção. 


\subsubsection{Projeto}

Uma das principais causas do colapso de muros costeiros é a erosão da base. Portanto, para salvaguardar as fundações desses muros, a fundação foi projetada, pelo menos, um metro abaixo da rampa de equilíbrio, com início na cota 1,2 m (adotada para a praia a inclinação 1V:10H).

Os estudos de estabilidade de taludes realizados para a concepção da solução do muro prevêem escavação da cunha superficial existente e tratamento de cunhas já mobilizadas, com um reaterro e berma de equilíbrio. Devido a um aumento na segurança foi concebido também uma substituição do solo argiloso por brita corrida numa vala com 2,0 m de largura na base.

O projeto do muro de pedra argamassada foi calculado considerando os parâmetros do solo, a sobrecarga de veículos, a pressão hidrostática, o empuxo do solo, a geometria do muro, verificação ao escorregamento, ao tombamento e das tensões na fundação. Os parâmetros de solo adotados estão na Tabela 4.3:

Tabela 4.3 Parâmetros do Projeto

\begin{tabular}{|c|c|c|c|}
\hline Solo & $\begin{array}{c}\text { Peso Específico } \\
\left(\mathrm{tf} / \mathrm{m}^{3}\right)\end{array}$ & $\begin{array}{c}\text { Ângulo de Atrito } \\
\text { (graus) }\end{array}$ & Coesão $\left(\mathrm{tf} / \mathrm{m}^{2}\right)$ \\
\hline Aterro Existente & 1,8 & 30 & 0,5 \\
\hline Solo de Fundação & 2 & 30 & 0 \\
\hline
\end{tabular}

FONTE: DER

Foram analisadas duas condições: a condição de trabalho, com o nível d'água atuando em ambos os lados com $1 \mathrm{~m}$ de altura exigindo fatores de segurança superiores a 1,5; e a condição mais crítica com rebaixamento rápido de 2 $\mathrm{m}$ para o muro de $4,20 \mathrm{~m}$ de altura (Figura 4.6), e rebaixamento de $1,5 \mathrm{~m}$ para o muro de 3,70 m (Figura 4.5), exigindo fatores de segurança superiores a 1,2. 0 empuxo passivo a favor da segurança não foi considerado.

Para a sobrecarga de veículos foi considerada uma pressão média de $2 \mathrm{tf} / \mathrm{m}^{2}$ para a condição de trabalho e de $1,0 \mathrm{tf} / \mathrm{m}^{2}$ para condição de rebaixamento rápido. 
Após realizadas várias análises e verificações, o projeto executivo de restauração consistiu em um muro de pedra argamassada, junto à plataforma da rodovia, ilustrado nas Figuras 4.5 e 4.6 .

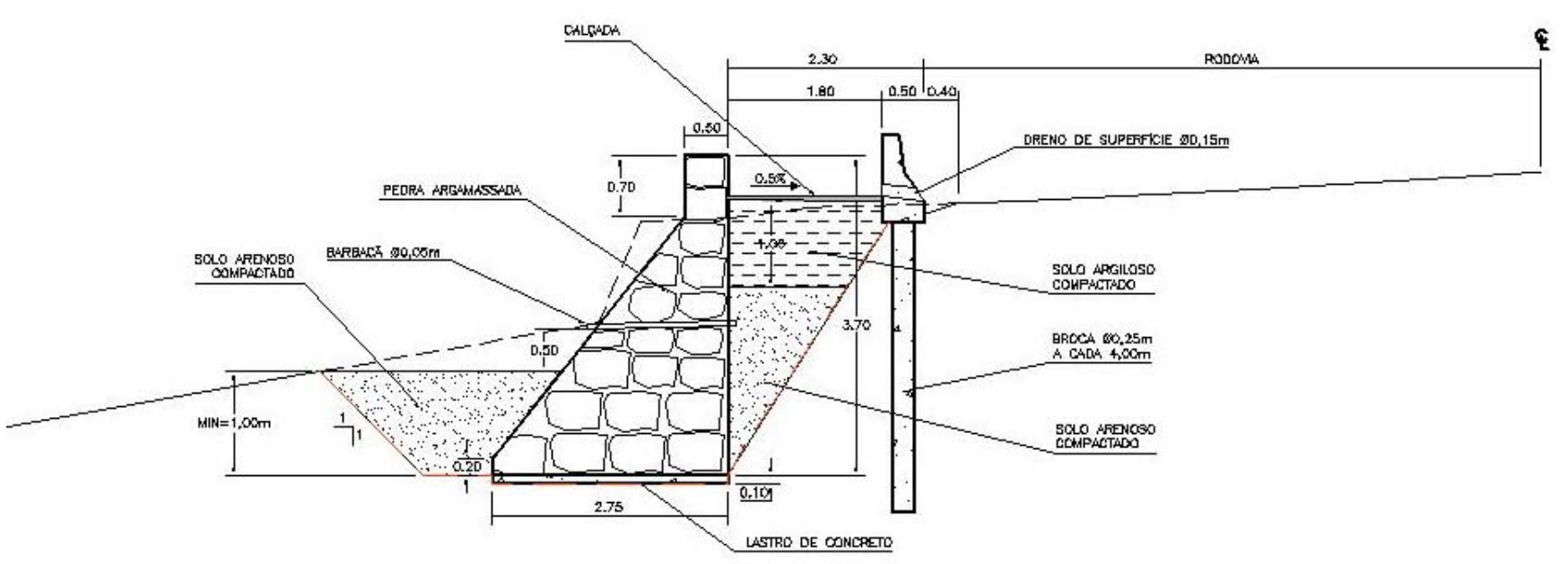

SEÇAO TIPO A $(\mathrm{H}=3,70 \mathrm{~m})$

Figura 4.5 Projeto de Restauração (A)

FONTE: DER / cadista "Chapolin" Colodo

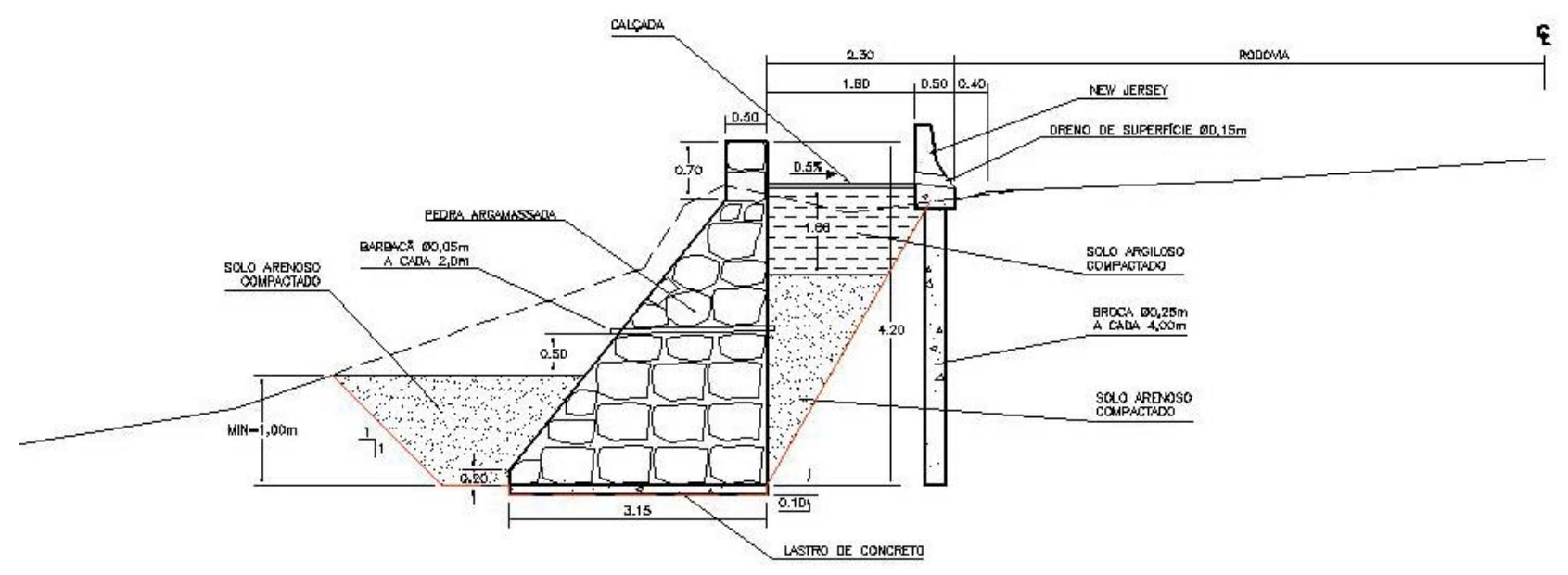

SECQAO TIPO B $(H=4,20 \mathrm{~m})$

Figura 4.6 Projeto de Restauração (B)

FONTE: DER / cadista "Chapolin" Colodo 
O muro tem uma extensão total de 500 metros e foi dividido em dois trechos (Figura 4.7). O primeiro trecho (Figura 4.5), sendo 380 metros, com seção tipo A de $3,70 \mathrm{~m}$ de altura e base de $2,75 \mathrm{~m}$, e o segundo trecho (Figura 4.6), de 120 metros, com seção tipo $B$ de $4,20 \mathrm{~m}$ de altura e base de $3,15 \mathrm{~m}$.

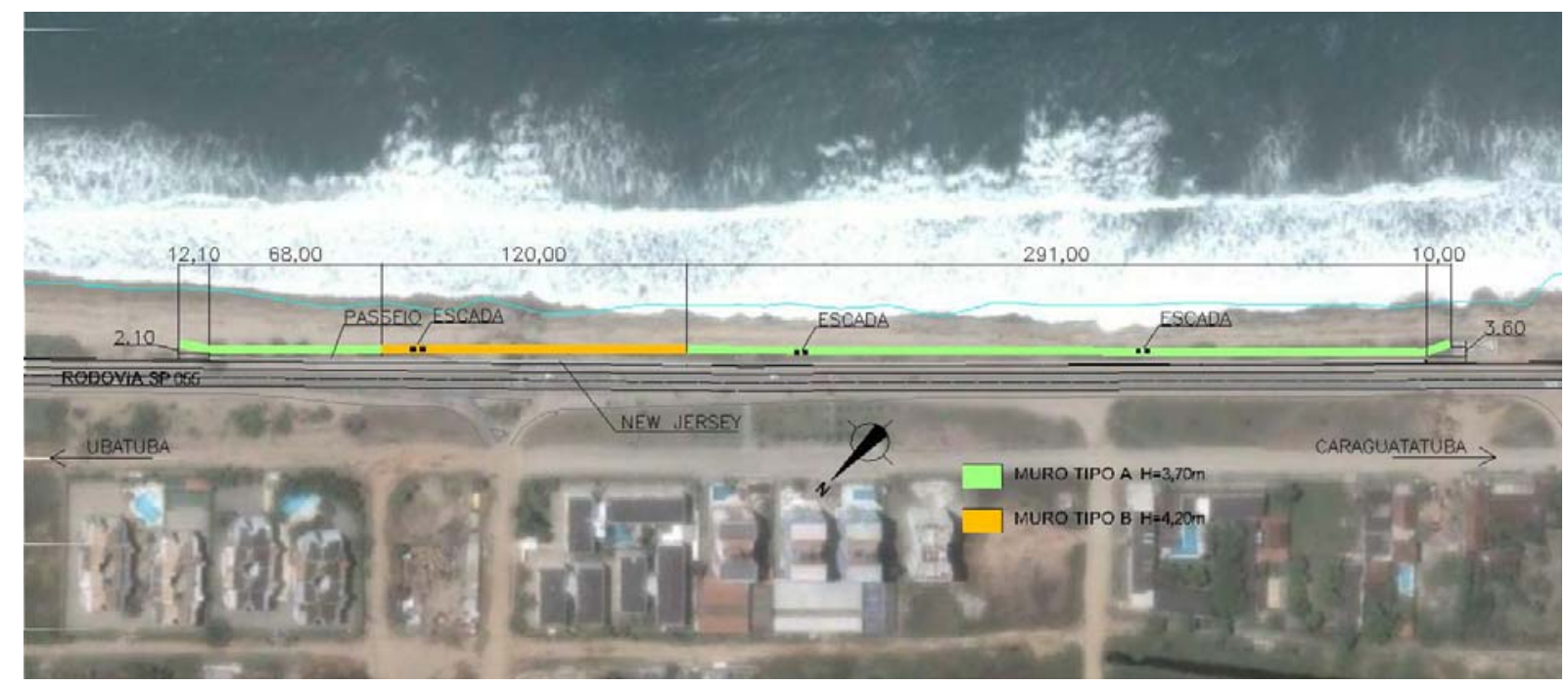

Figura 4.7 Vista Geral com o Projeto

FONTE: Google Earth / DER / cadista "Chapolin" Colodo

O projeto previu a necessidade da execução dos serviços de desmatamento, destocamento e limpeza.

A escavação foi feita juntamente com a execução do muro, e com o aterro a sua montante e sua jusante. Estava previsto que a frente de escavação não fosse superior a $5 \mathrm{~m}$ da frente de execução do primeiro metro de muro, para garantir a estabilidade e a segurança da obra.

Sempre que aconselhável, a critério da Fiscalização de obra, as massas em excesso, da escavação, foram integradas aos aterros, constituindo alargamentos da plataforma, taludes ou bermas de equilíbrio. As massas não utilizadas foram objeto de remoção, depositadas em bota-foras, para não constituir ameaça à estabilidade da rodovia, preservando os terrenos das adjacências quanto aos aspectos geotécnicos e ambientais.

Antes de iniciar a execução das camadas do muro em pedra argamassada, a área foi regularizada e compactada manualmente com equipamento vibratório. 
O aterro foi construído em camadas de espessuras uniformes, aproximadamente paralelas à linha de greide. O patamar apresentou uma inclinação transversal uniforme e descendente, cerca de $2 \%$.

Cada uma das camadas deveria ser homogênea quanto ao material, quanto à umidade no início da compactação e à massa específica aparente. A única heterogeneidade de materiais permitida em uma camada era aquela resultante de colocação de solos selecionados nas laterais dos aterros, para melhor protegê-los contra erosão.

No corpo do aterro deveria ser obtida massa específica aparente seca correspondente, no mínimo, a $98 \%$ da massa específica aparente máxima, no ensaio de compactação com energia normal (Proctor Normal).

Com relação ao controle tecnológico, o projeto previu ensaios para a determinação do grau de compactação e da umidade ótima do aterro em execução, em quantidades e locais a serem determinados pela Fiscalização, durante o andamento da obra. Para específicos tipos de solos poderia ser empregado o Método de Hilf no controle tecnológico.

Foram realizadas obras de acesso a praia para o conforto e segurança dos usuários, obras de drenagem superficial, e calçamento junto à praia. A drenagem foi executada por meio de canaletas e descidas d'água, que visam minimizar a erosão na base da contenção. O projeto previu a utilização de rebaixamento com ponteiras drenantes durante a execução das obras, caso ocorresse variação na maré, de modo a elevar o lençol freático.

Vale observar que, através dos estudos geológicos e ensaios geotécnicos da região, ficou constatado que a rodovia SP-55 funciona como um dique, protegendo assim as áreas baixas e já urbanizadas de Massaguaçu.

A seguir, na Figura 4.8, um histórico fotográfico da execução da obra do muro de pedra argamassada. 

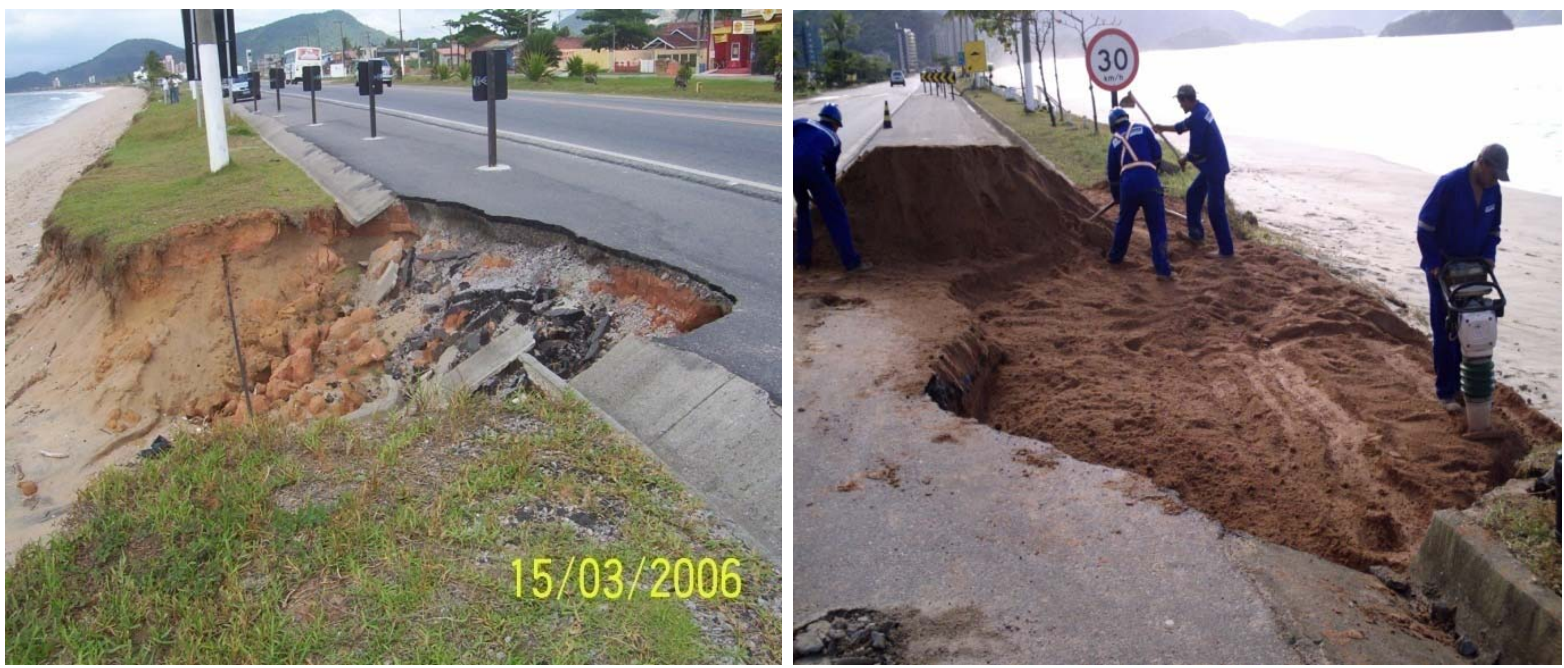

Erosões ocorridas atingindo o acostamento, anterior ao início do serviço. Início de aterro e compactação no local das erosões.

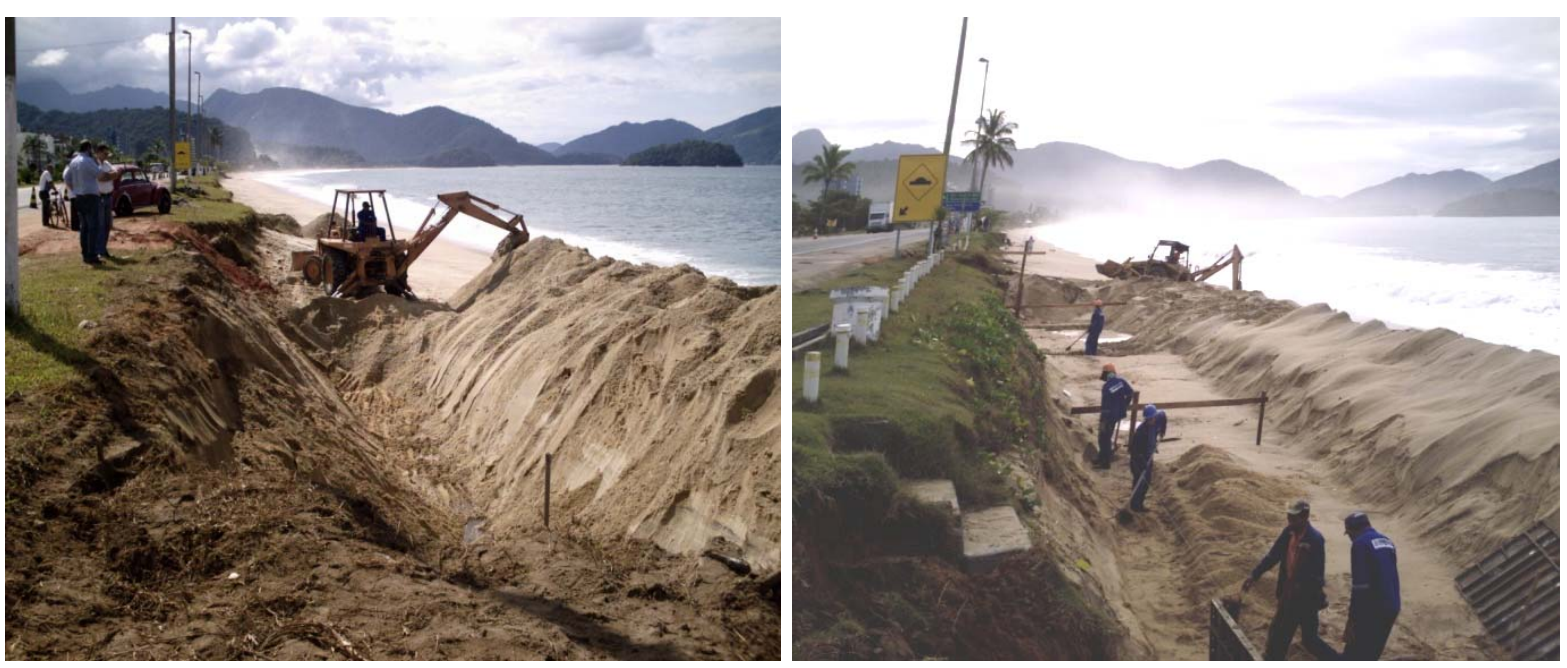

Início da escavação mecânica na área atingida pela erosão. Escavação manual para alinhamento da base do muro.
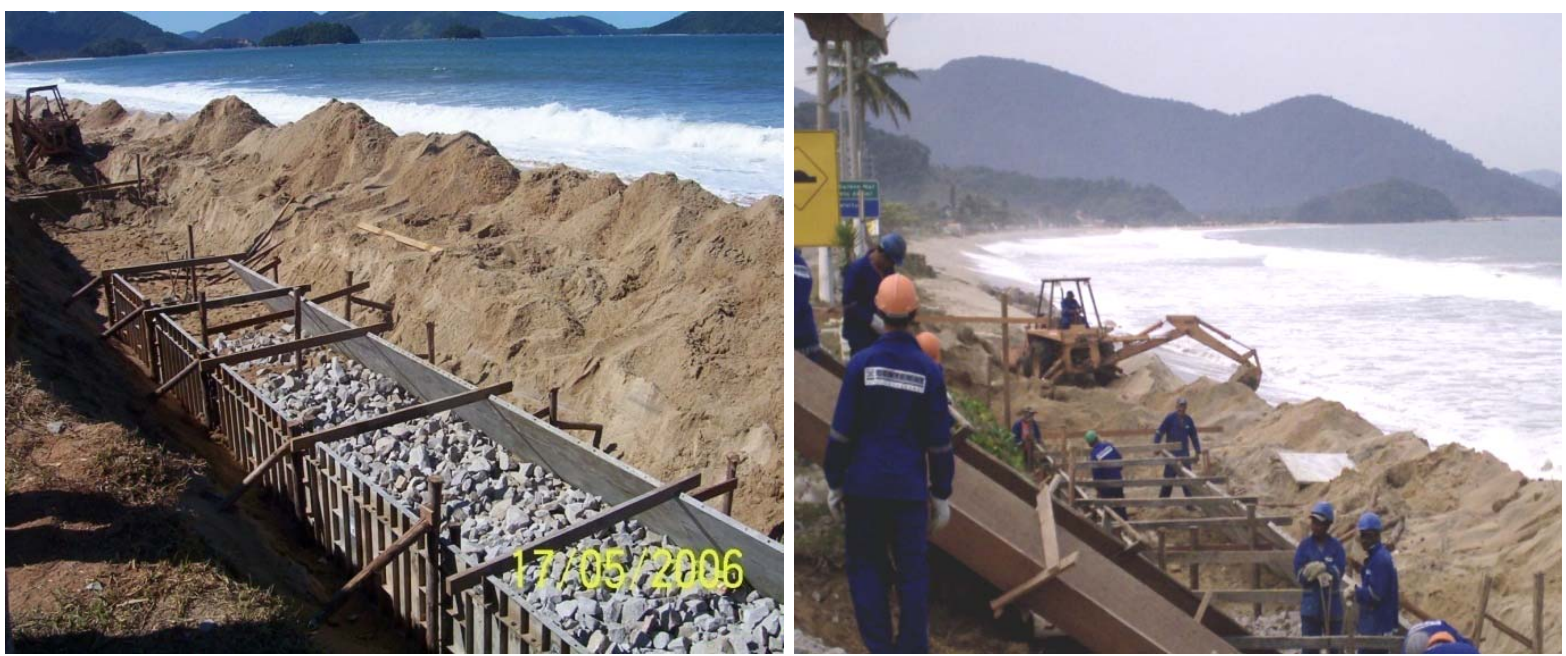

Execução da base do muro de contenção. Colocação de fôrmas e escoramento para execução do muro de contenção. 

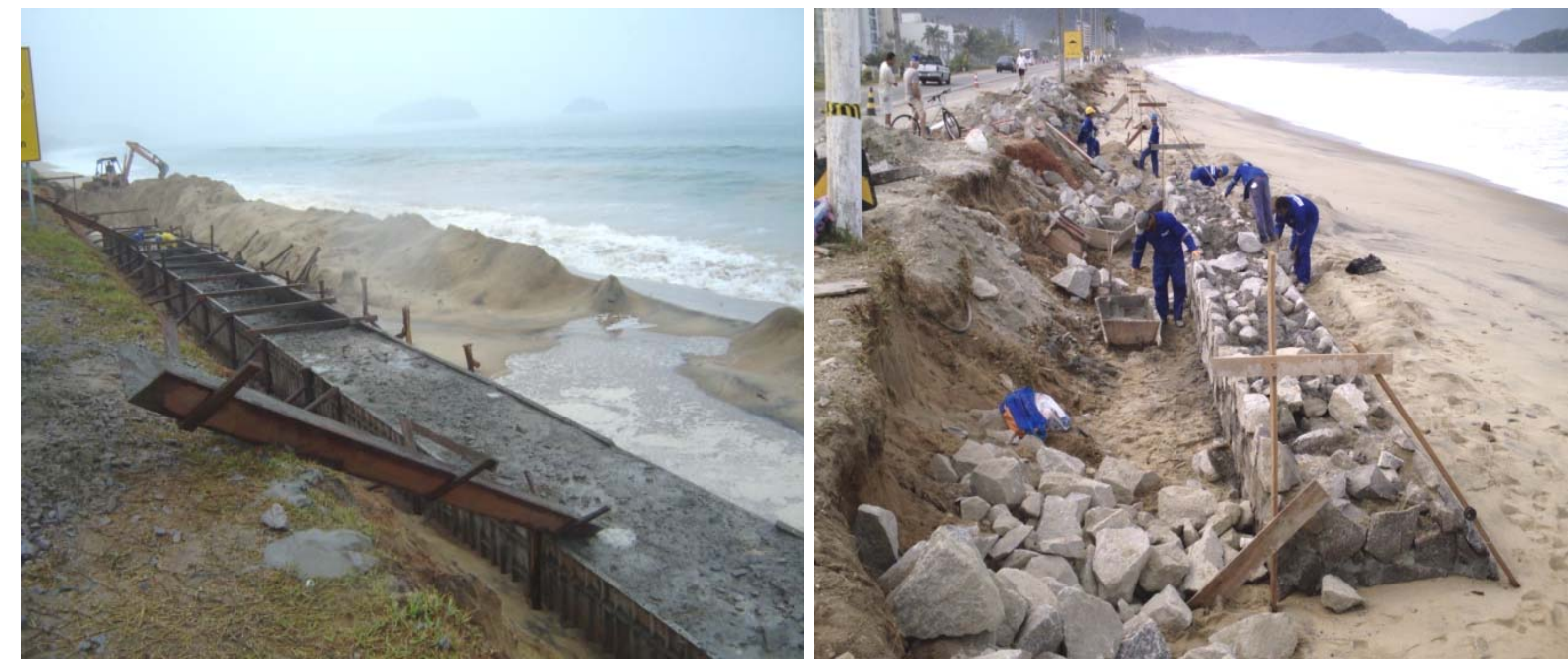

Dificuldade na execução da base por causa dos dias chuvosos e da maré alta. Início da construção do muro de pedra argamassada.

Figura 4.8 Histórico Fotográfico da Execução do Muro de Pedra Argamassada

\subsection{EROSÕES OBSERVADAS}

No dia 6 de junho de 2006, devido a uma forte ressaca do mar, a obra de contenção, na praia de Massaguaçu, foi erodida em cerca de 160 metros, dos 270 metros de muro já construídos (Figura 4.9), sendo que parte da superfície inferior do muro de proteção, devido ao solapamento, foi carreada para dentro do mar e alguns blocos de concreto foram arrastados para a praia (Figura 4.10).
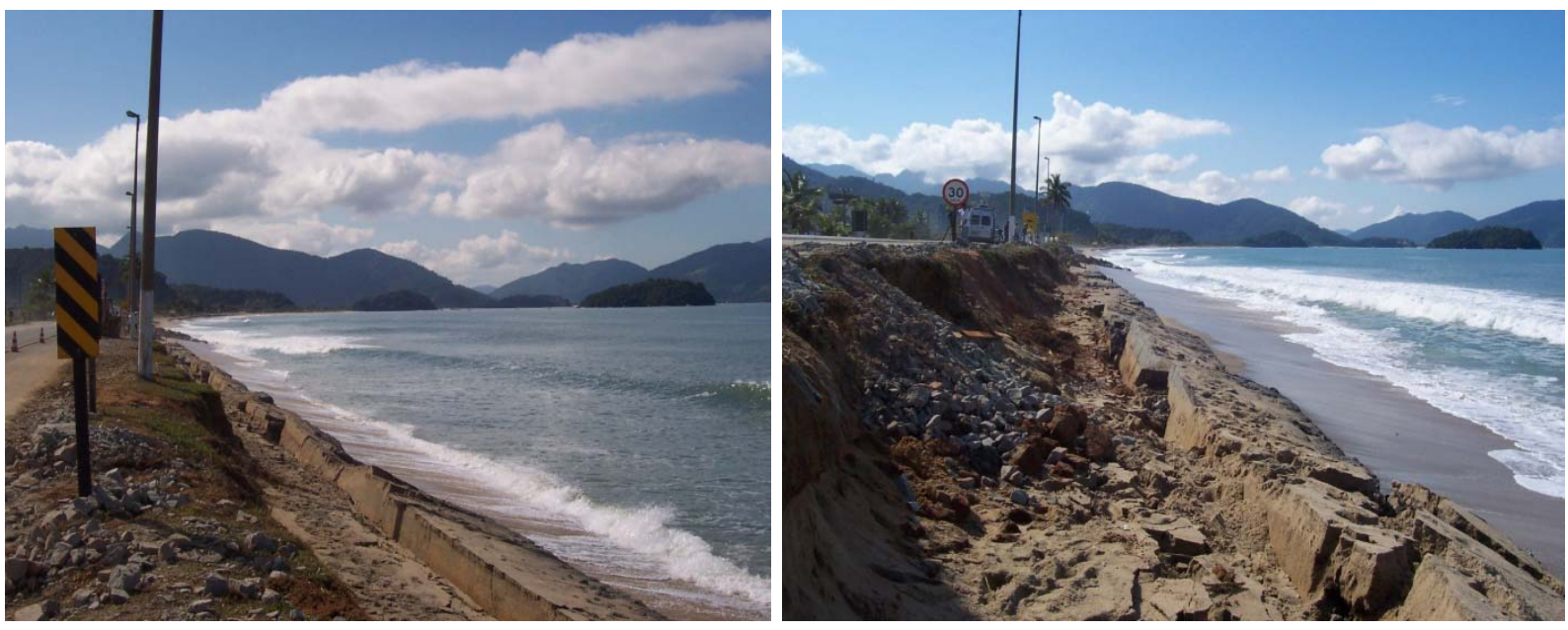

Figura 4.9 Solapamento de 160 metros de Muro de Contenção (2006) 

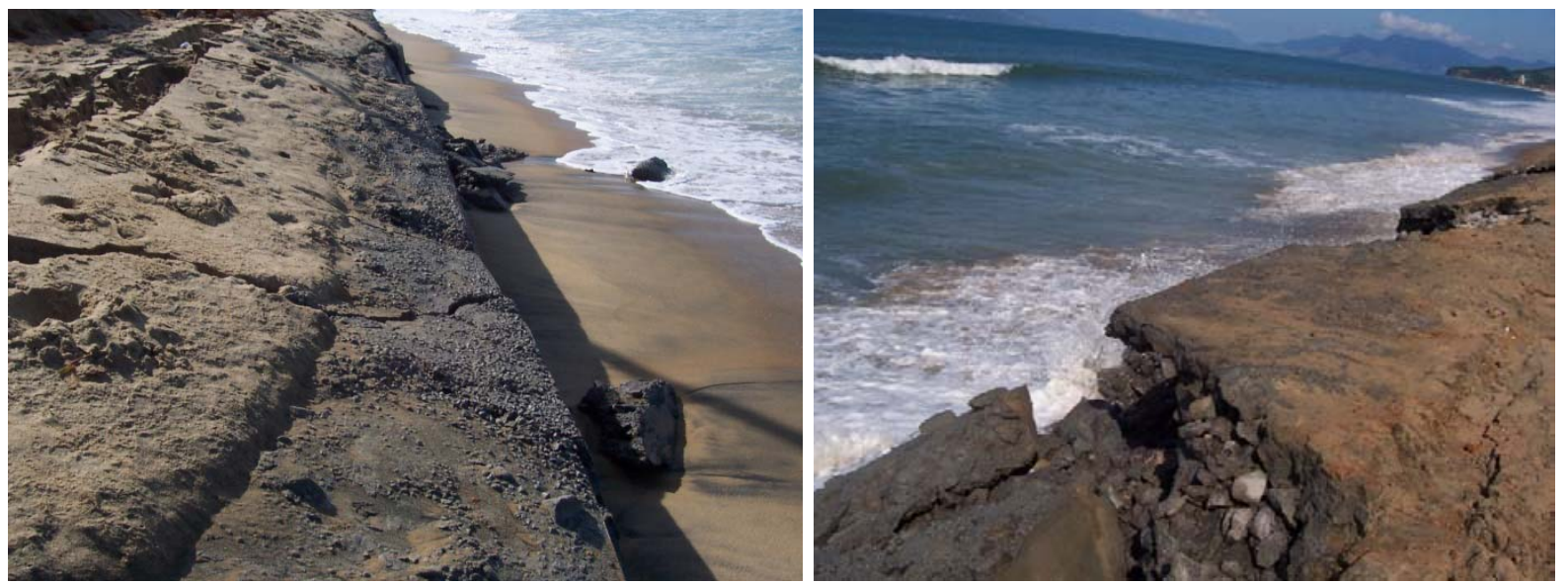

Figura 4.10 Detalhe do Muro Erodido (2006)

O espraiamento das ondas de tempestade ao atingir a obra, que encontrava em execução a escavação e a base do muro de proteção da Rodovia SP-55, produziu intensa refletividade, devido ao escarpamento íngreme, e com o incremento da velocidade das ondas, no estirâncio superior e pós-praia, propiciou a erosão e o solapamento da base da estrutura, de acordo com o esquema da Figura 4.11.

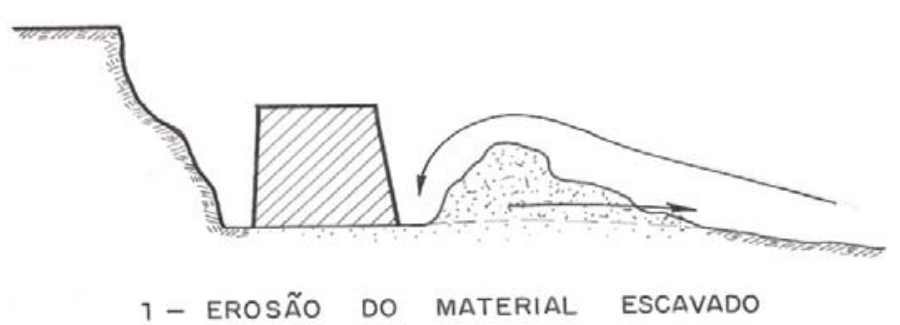

1 - EROSÃo do material EScAVAdo
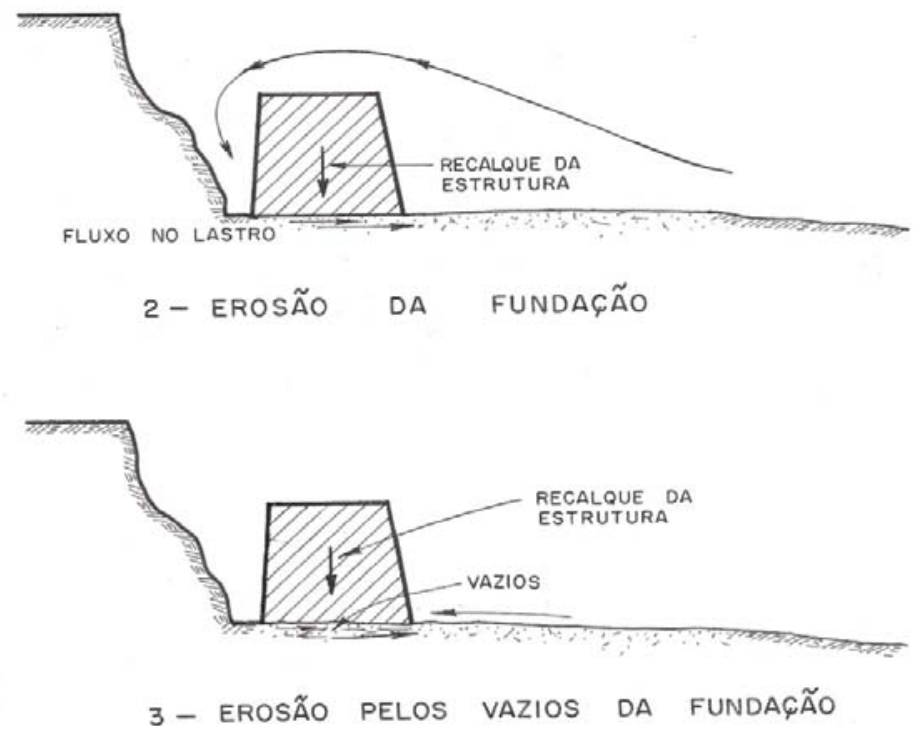

Figura 4.11 Esquema da Erosão na Fundação do Muro FONTE: DER 
Nesse cenário, houve a suspensão temporária das obras, como medida de segurança e proteção ao interesse público. Em seguida, começaram a ser analisadas diversas propostas de soluções, e reestudo do projeto e de suas características, a fim de uma readequação na proteção da costa.

\subsection{ESTUDO DE DADOS E PROJETO DE RECONSTRUÇÃO}

A Rodovia SP-55 no trecho da Praia de Massaguaçu, no Município da Estância Balneária de Caraguatatuba, necessita de obras de proteção da pista em defesa das ações hidrodinâmicas dos processos litorâneos, que erodem o perfil praial e inundam a pista, ameaçando a funcionalidade da rodovia.

Para a definição da concepção de obra a ser adotada, torna-se necessário dispor de uma descrição conceitual dos agentes ambientais a serem considerados para o dimensionamento da obra costeira.

\subsubsection{Dados}

Na concepção geral para as medidas de proteção e contenção da erosão na Rodovia Dr. Manuel Hyppolito Rego - SP-55 (entre os km 89 a 91 (LE), na Praia de Massaguaçu) foi acrescido ao levantamento de dados de 2005, informações abrangendo os estudos de morfodinâmica praial, estudos sobre as marés, caracterização da agitação do clima de ondas, e o cálculo do espraiamento das ondas. 


\subsubsection{Morfodinâmica Praial}

A Praia de Massaguaçu encontra-se numa enseada delimitada pela Ponta Martim de Sá e Ponta da Tabatinga. Situa-se entre a foz do Rio Capricórnio (também chamado Rio Getuba) até o través com a llha Cocanha, numa extensão de aproximadamente $6 \mathrm{~km}$, onde nota-se uma gradual mudança das características gerais da praia. Portanto, consideramos a Praia de Massaguaçu uma faixa de $3 \mathrm{~km}$ a partir da foz do Rio Capricórnio.

Neste trecho, a praia é constituída por areia grossa, sendo considerada uma praia de tombo com uma largura mínima de espraiamento, e a arrebentação é mergulhante. O perfil é bastante íngreme em toda a sua extensão, e a foz do rio normalmente é barrada pelo grande aporte de sedimentos, dando origem a uma lagoa chamada Lagoa Azul (Figura 4.12).

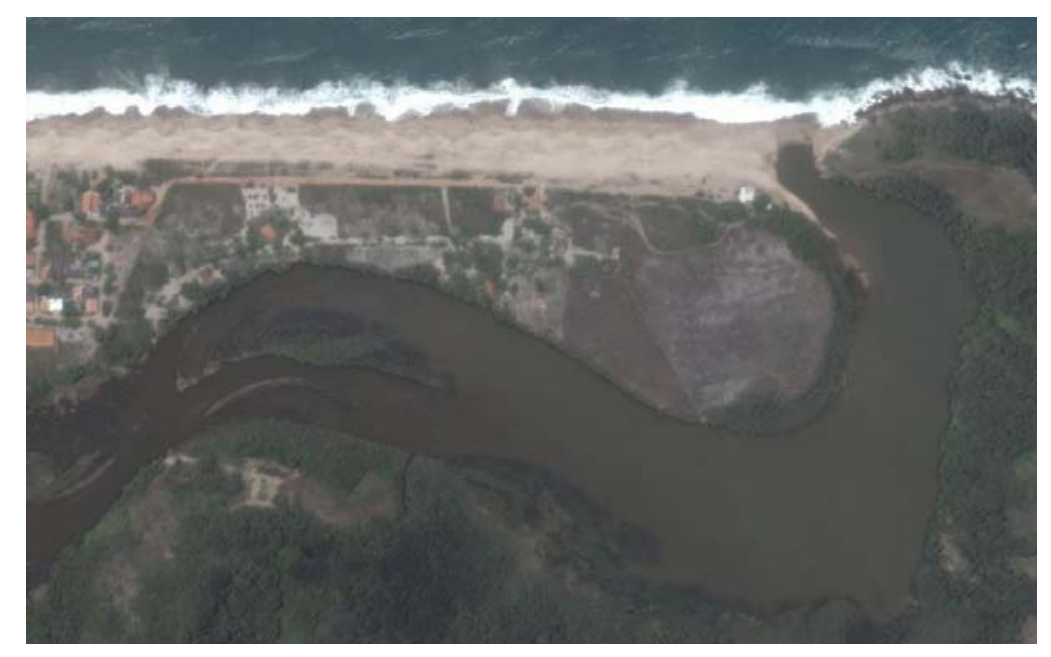

Figura 4.12 Lagoa Azul

FONTE: Google Earth

De forma geral, o litoral do Estado de São Paulo não apresenta anomalias nas batimetrias, como a presença de vales submarinos, recifes ou grandes bancos de areia significativos. A batimetria normalmente segue a morfologia da linha de costa e ilhas sem grandes particularidades.

Com base na Carta Náutica 1614, cujo trecho da Praia de Massaguaçu está apresentado nas Figuras 4.13 e 4.14, observam-se os contornos batimétricos em cotas DHN (Diretoria de Hidrografia e Navegação) da Marinha do Brasil. 


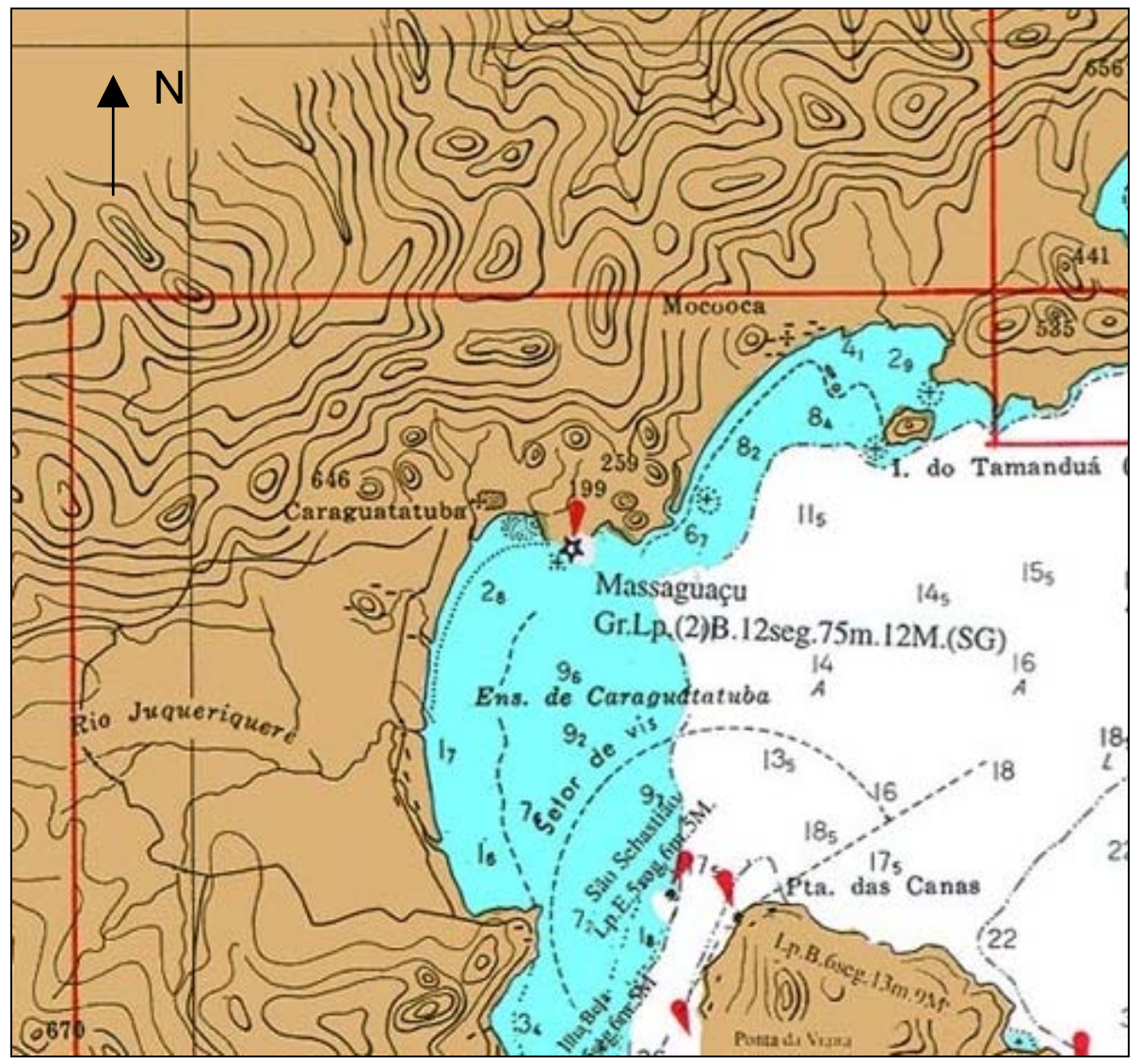

Figura 4.13 Carta Náutica 1614 da DHN

De acordo com a Carta Náutica (Figura 4.14), a Praia de Massaguaçu tem ortogonal com azimute $114,5^{\circ} \mathrm{NV}$ (rumo ESE).

Também é possível analisar que a isóbata de 6,00 m (cota IBGE) situa-se a cerca de $300 \mathrm{~m}$ da linha de costa, e a isóbata de 4,00 m (cota IBGE) situa-se de 100 a 150 metros, predominando arrebentação mergulhante com formação de cúspides praiais. 


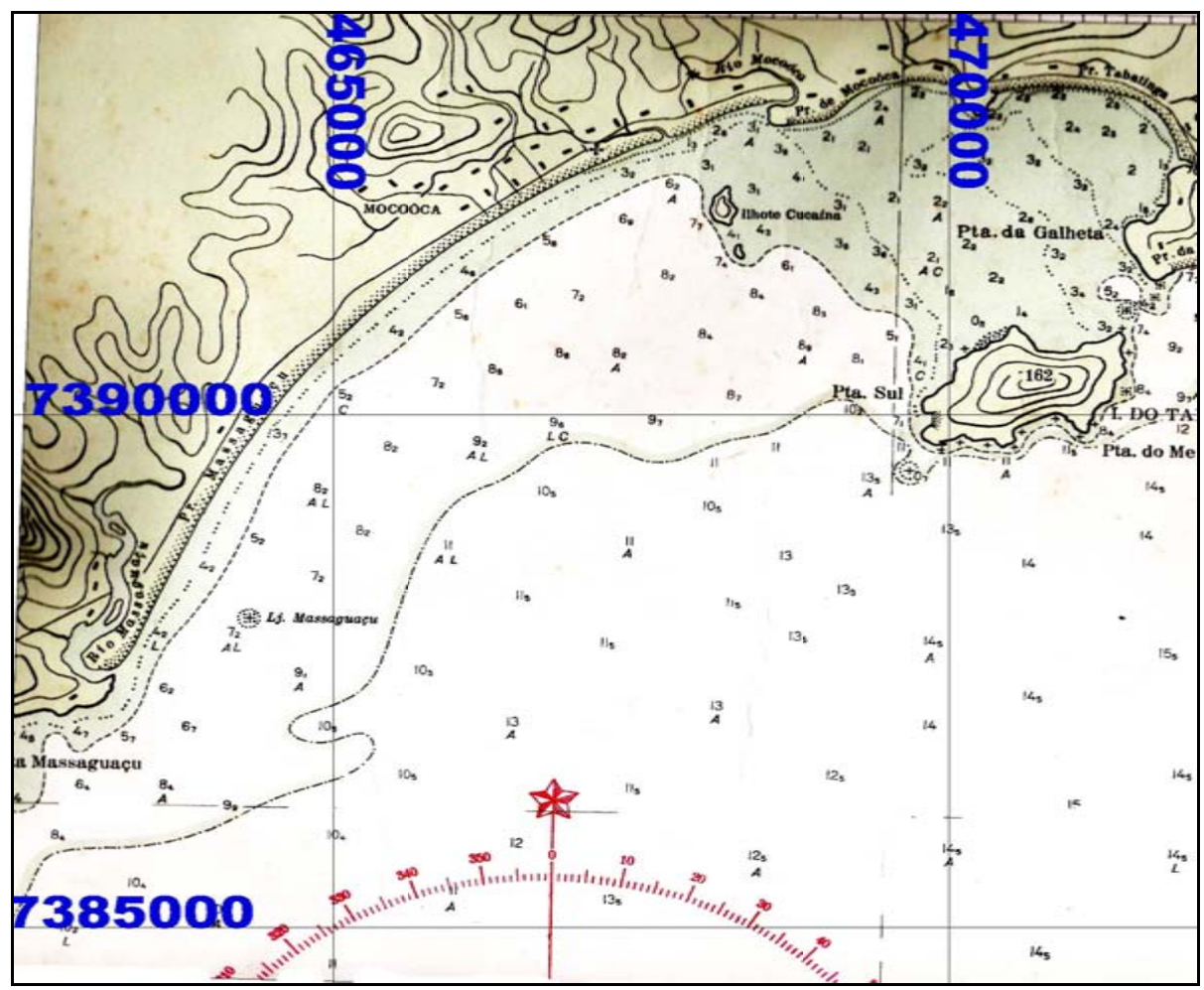

Figura 4.14 Trecho da Carta Náutica DHN 1614

Segundo Souza (1990 e 1997), com base em medições de perfis praiais na Praia de Massaguaçu, em períodos de inverno (junho e julho) e verão (janeiro e fevereiro), a declividade do pós-praia (região com altura acima da preamar) oscila entre $1 \mathrm{~V}: 4 \mathrm{H}$ e $1 \mathrm{~V}: 5 \mathrm{H}$, enquanto o trecho do estirâncio (entre marés) oscila entre $1 \mathrm{~V}: 6 \mathrm{H}$ e $1 \mathrm{~V}: 9 \mathrm{H}$, respectivamente.

Estes valores são coerentes com os dois perfis de praia levantados em setembro de 2005 e junho de 2006, em que a declividade do estirâncio é da ordem de $1 \mathrm{~V}: 6 \mathrm{H}$.

Foi levantada, também, a evolução da linha de costa com base no estudo aerofotogramétrico. Não houve nenhuma mudança significativa em mais de 40 anos de levantamentos do local, conforme Figura 4.15. Esta foto refere-se aos vôos de 1962, 1994 e 2004, obtidas da BASE aerofotogrametria e projetos S.A. Efetuou-se a comparação georeferenciada, superpondo as 3 linhas de costa dos diferentes anos (Alfredini, 2006).

A percepção de significativas oscilações da largura do perfil praial deve-se às oscilações sazonais em períodos de forte agitação, quando predomina a erosão, e períodos de maior calmaria, quando predomina o engordamento da praia. 


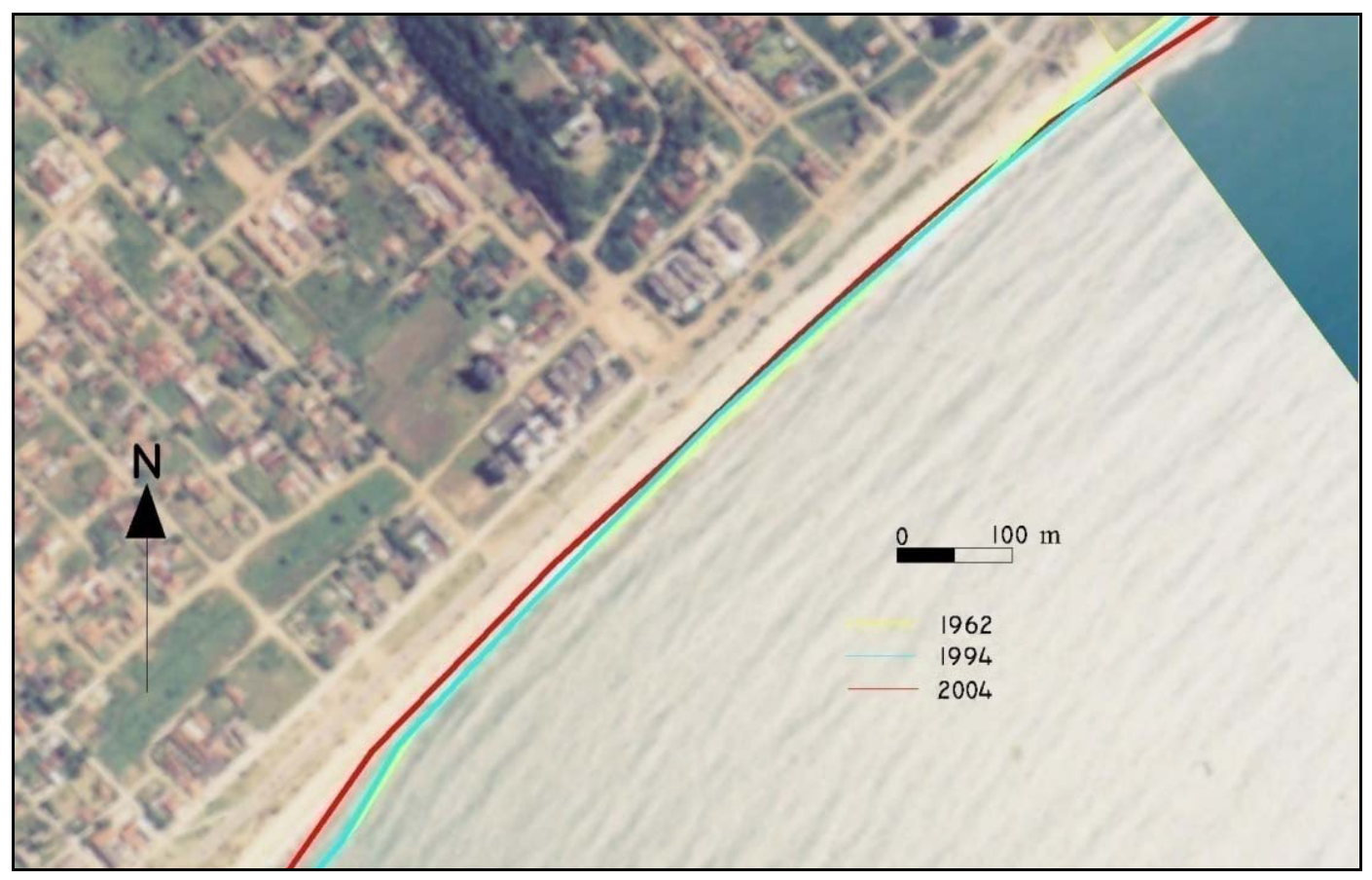

Figura 4.15 Evolução da Linha de Costa FONTE: Alfredini, 2006

Segundo estudo de Araújo (2005), a Praia de Massaguaçu tem setor de exposição à agitação ondulatória limitado aos octantes E e SE, e em função desta característica, apresenta reduzido transporte de sedimentos litorâneo longitudinal, como observado na rosa de percentual de transporte de sedimentos (Figura 4.16), estimado em $18.557 \mathrm{~m}^{3}$ /ano, predominando a dinâmica transversal de basculamento do perfil praial.

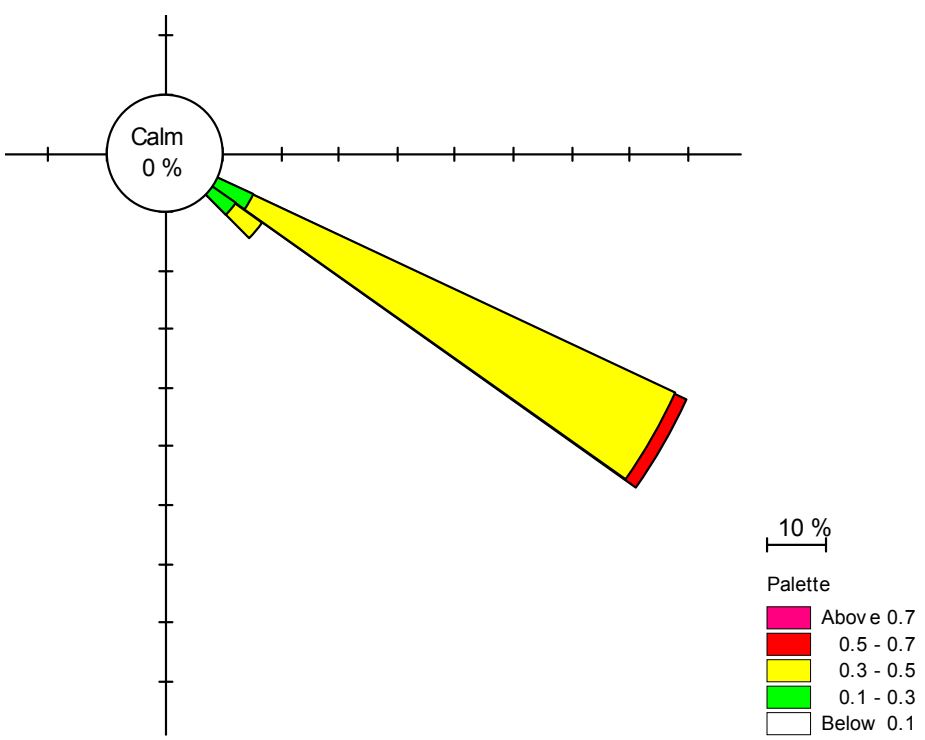

Figura 4.16 Rosa de Transporte de Sedimentos Litorâneo Longitudinal FONTE: Araújo, 2005 


\subsubsection{Marés}

O litoral do Estado de São Paulo apresenta uma condição de maré com amplitudes médias em sizígia (nas Luas Nova e Cheia, as forças gravitacionais do Sol estão na mesma direção das forças da Lua, produzindo as marés mais altas) em torno de 1,20 m. Não há rios de grande porte neste litoral e nem grandes baías confinadas que gerem ressonância e amplificação da maré de forma significativa (Araújo, 2005).

O nível médio do mar tem variabilidade de baixa freqüência, associada a efeitos meteorológicos. Então, consideramos o nível do mar observado como a soma da maré astronômica, de freqüências diurnas e semi-diurnas previstas na tábua de maré, com a maré meteorológica, que não é determinística, e é devida a eventos meteorológicos.

Observa-se que o zero do IBGE corresponde ao nível médio do mar no marégrafo de Imbituba (SC), enquanto o nível de redução da DHN da Marinha do Brasil corresponde à baixa-mar média de sizígia do local. O litoral do Estado de São Paulo obedece a uma diferença de cotas de $+0,80 \mathrm{~m}$ a ser adicionado às cotas IBGE para se obter as cotas DHN.

Segundo estudos de Alfredini (2006), regiões sujeitas às mesmas condições meteorológicas e oceanográficas tendem a apresentar as mesmas distribuições de freqüências da variação do nível médio do mar, significando que podem ser utilizados dados do nível médio do mar relativos a uma estação permanente, obtidos através de uma análise de longo período e que contenham a influência meteorológica, para outra estação localizada na mesma região, mas que possua somente uma série mais curta de dados.

Conforme demonstrado pelos dados maregráficos, as marés em Santos (estação em Torre Grande) não diferem muito das marés em Ubatuba (estação na Base Norte do Instituto Oceanográfico da Universidade de São Paulo, na Enseada do Flamengo), segundo o estudo de Garcia Occhipinti (1989).

A análise de dados maregráficos de 50 anos da estação permanente do Porto de Santos (1944 a 1993) aponta a ocorrência de 5 preamares em torno à cota 1,40 
m (cota IBGE), sendo que nestes eventos a maré meteorológica positiva sobrelevou o nível da maré astronômica previsto entre 70 e $80 \mathrm{~cm}$ (Alfredini, 2005). Assim, a probabilidade destes eventos pode ser estimada, em média, como decenal, sendo possível estimar preamares extremas de 1,30 m, 1,40 m e 1,50 m (cota IBGE), respectivamente para 5,10 e 50 anos de período de retorno.

Nas Tabelas 4.4 e 4.5 estão apresentadas as fichas maregráficas do Porto de Santos e da Estação Ubatuba do IOUSP (Fundação de Estudos do Mar - FEMAR, 2000). Observe que os dados estão em relação ao nível de redução da DHN da Marinha do Brasil. 
Tabela 4.4 Ficha maregráfica do Porto de Santos

FEMAR-FUNDAÇÃO DE ESTUDOS DO MAR Catálogo de Estações Maregráficas Brasileiras

\begin{tabular}{|c|c|c|c|c|c|c|}
\hline \multicolumn{2}{|c|}{ Nome da Estação : } & \multicolumn{5}{|c|}{ SANTOS (PORTO) - SP } \\
\hline \multicolumn{2}{|r|}{ Localização : } & \multicolumn{5}{|c|}{ Na torre de passagem dos cabos elétricos pelo canal (Torre Grande) } \\
\hline \multicolumn{2}{|c|}{ Organ. Responsável : } & \multicolumn{5}{|c|}{ INPH / CODESP / DHN } \\
\hline \multicolumn{2}{|c|}{ Latitude : } & \multicolumn{2}{|c|}{$23^{\circ} 57,3^{\prime} \mathbf{S}$} & \multicolumn{2}{|c|}{ Longitude : } & $46^{\circ} 18,6^{\prime} \quad W$ \\
\hline \multicolumn{2}{|c|}{ Período Analisado : } & \multicolumn{2}{|c|}{$01 / 01 / 56$ a $23 / 12 / 56$} & \multicolumn{3}{|c|}{$\mathbf{N}^{\circ}$ de Componentes : } \\
\hline \multicolumn{2}{|c|}{$\begin{array}{r}\text { Análise Harmônica : } \\
\text { Classificação : }\end{array}$} & \multicolumn{5}{|c|}{$\begin{array}{l}\text { Método Tidal Liverpool Institute } \\
\text { Maré de Desigualdades Diurnas }\end{array}$} \\
\hline \multicolumn{2}{|c|}{$\begin{array}{c}\begin{array}{c}\text { Estabelecimento do Porto: } \\
\text { (HWF\&C) }\end{array} \\
\end{array}$} & \multicolumn{2}{|c|}{ II $\mathrm{H} \quad 55 \mathrm{~min}$} & \multicolumn{2}{|c|}{$\begin{array}{c}\text { Nível Médio } \\
\left(\mathbf{Z}_{0}\right):\end{array}$} & $\begin{array}{r}77 \mathrm{~cm} \\
\text { acima do NR. } \\
\end{array}$ \\
\hline \multicolumn{2}{|c|}{$\begin{array}{l}\text { Média das Preamares } \\
\text { Superiores (MHHW): }\end{array}$} & \multicolumn{2}{|c|}{ acima do NR. $141 \mathrm{~cm}$} & \multicolumn{2}{|c|}{$\begin{array}{l}\text { Média das Preamares } \\
\text { Inferiores (MLHW): }\end{array}$} & $\begin{array}{r}130 \mathrm{~cm} \\
\text { acima do NR } \\
\end{array}$ \\
\hline \multicolumn{2}{|c|}{$\begin{array}{l}\text { Média das Baixa-mares } \\
\text { Superiores (MHLW) : }\end{array}$} & \multicolumn{2}{|c|}{ acima do NR. $29 \mathrm{~cm}$} & \multicolumn{2}{|c|}{$\begin{array}{l}\text { Média das Baixa-mares } \\
\text { Inferiores (MLLW): }\end{array}$} & $\begin{array}{r}7 \mathrm{~cm} \\
\text { acima do NR. }\end{array}$ \\
\hline \multicolumn{7}{|c|}{ CONSTANTES HARMÔNICAS SELECIONADAS } \\
\hline Componentes & $\begin{array}{l}\text { Semi- } \\
\text { amplitude } \\
\text { (H) } \mathrm{cm}\end{array}$ & $\begin{array}{l}\text { Fase (g) } \\
\text { graus }\left({ }^{\circ}\right)\end{array}$ & & nponentes & $\begin{array}{l}\text { Semi- } \\
\text { amplitude } \\
\text { (H) } \mathrm{cm}\end{array}$ & $\begin{array}{l}\text { Fase (g) } \\
\text { graus }\left({ }^{\circ}\right)\end{array}$ \\
\hline Sa & 10,2 & 025 & & $\mathbf{M U}_{2}$ & 2,1 & 122 \\
\hline Ssa & 5,0 & 180 & & $\mathbf{N}_{2}$ & 5,4 & 149 \\
\hline Mm & 4,2 & 289 & & $\mathrm{NU}_{2}$ & 0,4 & 139 \\
\hline Mf & 1,7 & 141 & & $\mathbf{M}_{2}$ & 36,4 & 088 \\
\hline MTM & - & - & & $\mathbf{L}_{2}$ & 1,6 & 037 \\
\hline Msf & 1,5 & 121 & & $\mathbf{T}_{2}$ & 0,8 & 020 \\
\hline $\mathbf{Q}_{1}$ & 2,5 & 058 & & $\mathbf{S}_{2}$ & 22,5 & 091 \\
\hline $\mathbf{O}_{1}$ & 11,5 & 081 & & $\mathbf{K}_{2}$ & 7,4 & 082 \\
\hline $\mathbf{M}_{1}$ & 0,8 & 095 & & $\mathrm{MO}_{3}$ & 0,7 & 096 \\
\hline $\mathbf{P}_{1}$ & 2,3 & 136 & & $\mathbf{M}_{3}$ & 4,9 & 234 \\
\hline $\mathbf{K}_{1}$ & 6,3 & 143 & & MK $_{3}$ & 2,5 & 117 \\
\hline $\mathbf{J}_{1}$ & 0,8 & 192 & & $\mathrm{MN}_{4}$ & 1,3 & 318 \\
\hline $\mathrm{OO}_{1}$ & 0,2 & 133 & & $\mathbf{M}_{4}$ & 2,6 & 355 \\
\hline $\mathrm{MNS}_{2}$ & 0,2 & 189 & & $\mathbf{S N}_{4}$ & 0,6 & 061 \\
\hline $2 \mathbf{N}_{2}$ & 2,0 & 149 & & $\mathbf{M S}_{4}$ & 2,2 & 143 \\
\hline \multicolumn{7}{|c|}{ Referências de Nível: $\quad R$} \\
\hline \multicolumn{7}{|c|}{$\begin{array}{ll}\text { Obs: } & \text { Outros Periodos: 01/01/51 a } 04 / 01 / 51 ; 14 / 11 \\
& 05 / 09 / 95 \text { a } 07 / 10 / 95 . \\
& \text { Existem outros periodos no INPH e na CODESP } \\
& \text { Consta das Tábuas das Marés. }\end{array}$} \\
\hline
\end{tabular}

Código BNDO: 50225 
Tabela 4.5 Ficha maregráfica da Estação da Base Norte do IOUSP

FEMAR-FUNDAÇÃO DE ESTUDOS DO MAR Catálogo de Estações Maregráficas Brasileiras

\begin{tabular}{|c|c|c|c|c|c|c|}
\hline \multirow{2}{*}{\multicolumn{2}{|c|}{$\begin{array}{r}\text { Nome da Estação : } \\
\text { Localização : }\end{array}$}} & \multicolumn{5}{|c|}{ UBATUBA - SP } \\
\hline & & \multicolumn{5}{|c|}{ No trapiche de atracaçăo da Estaçăo de Pesquisa do IOUSP } \\
\hline \multicolumn{2}{|c|}{ Organ. Responsável : } & \multicolumn{5}{|c|}{ Instituto Oceanográfico da Universidade de Săo Paulo - IOUSP } \\
\hline \multicolumn{2}{|r|}{ Latitude : } & \multirow{2}{*}{\multicolumn{2}{|c|}{$23^{\circ} 30,0^{\prime} \mathbf{S}$}} & \multicolumn{3}{|c|}{ Longitude : $\quad 45^{\circ} 07,3^{\prime} \quad$ W } \\
\hline \multicolumn{2}{|c|}{ Período Analisado: } & & & \multicolumn{2}{|c|}{$\mathrm{N}^{\circ}$ de Componentes : } & 62 \\
\hline \multicolumn{2}{|c|}{$\begin{array}{r}\text { Análise Harmônica : } \\
\text { Classificação : } \\
\end{array}$} & \multicolumn{5}{|c|}{$\begin{array}{l}\text { Método Almirante Santos Franco } \\
\text { Maré de Desigualdades Diurnas }\end{array}$} \\
\hline \multicolumn{2}{|c|}{$\begin{array}{c}\text { Estabelecimento do Porto: } \\
\text { (HWF\&C) }\end{array}$} & \multicolumn{2}{|c|}{ II $\mathrm{H} 33 \mathrm{~min}$} & \multicolumn{2}{|c|}{$\begin{array}{c}\text { Nível Médio } \\
\left(Z_{0}\right):\end{array}$} & $\begin{array}{r}69 \mathrm{~cm} \\
\text { acima do Zero. } \\
\end{array}$ \\
\hline \multicolumn{2}{|c|}{$\begin{array}{l}\text { Média das Preamares } \\
\text { Superiores (MHHW): }\end{array}$} & \multicolumn{2}{|c|}{$\begin{array}{l}119 \mathrm{~cm} \\
\text { acima do NR. }\end{array}$} & \multicolumn{2}{|c|}{$\begin{array}{l}\text { Média das Preamares } \\
\text { Inferiores (MLHW): }\end{array}$} & $\begin{array}{l}112 \mathrm{~cm} \\
\text { acima do NR }\end{array}$ \\
\hline \multicolumn{2}{|c|}{$\begin{array}{l}\text { Média das Baixa-mares } \\
\text { Superiores (MHLW): }\end{array}$} & \multicolumn{2}{|c|}{\begin{tabular}{|l}
$33 \mathrm{~cm}$ \\
acima do NR.
\end{tabular}} & \multicolumn{2}{|c|}{$\begin{array}{l}\text { Média das Baixa-mares } \\
\text { Inferiores (MLLW): }\end{array}$} & \begin{tabular}{|r}
$11 \mathrm{~cm}$ \\
acima do NR.
\end{tabular} \\
\hline \multicolumn{7}{|c|}{ CONSTANTES HARMONICAS SELECIONADAS } \\
\hline Componentes & $\begin{array}{l}\text { Semi- } \\
\text { amplitude } \\
\text { (H) } \mathrm{cm}\end{array}$ & $\begin{array}{l}\text { Fase (g) } \\
\left.\text { graus ( }{ }^{\circ}\right)\end{array}$ & & mponentes & $\begin{array}{l}\text { Semi- } \\
\text { amplitude } \\
\text { (H) } \mathrm{cm}\end{array}$ & $\begin{array}{l}\text { Fase (g) } \\
\left.\text { Graus ( }{ }^{\circ}\right)\end{array}$ \\
\hline Sa & 7,9 & 037 & & $\mathbf{M U}_{2}$ & 1,5 & 091 \\
\hline Ssa & - & - & & $\mathbf{N}_{2}$ & 3,7 & 131 \\
\hline Mm & - & - & & $\mathbf{N U}_{2}$ & 0,4 & 124 \\
\hline Mf & - & - & & $\mathbf{M}_{2}$ & 29,7 & 079 \\
\hline MTM & - & - & & $\mathbf{L}_{2}$ & 1,4 & 095 \\
\hline Msf & - & - & & $T_{2}$ & - & - \\
\hline $\mathbf{Q}_{1}$ & 3,1 & 054 & & $\mathbf{S}_{2}$ & 17,2 & 082 \\
\hline $\mathbf{O}_{1}$ & 10,9 & 084 & & $\mathbf{K}_{2}$ & 5,4 & 074 \\
\hline $\mathbf{M}_{1}$ & 0,5 & 243 & & $\mathrm{MO}_{3}$ & 1,0 & 009 \\
\hline $\mathbf{P}_{1}$ & 2,0 & 133 & & $\mathbf{M}_{3}$ & 1,4 & 211 \\
\hline $\mathbf{K}_{1}$ & 5,9 & 142 & & $\mathbf{M K}_{3}$ & 0,5 & 117 \\
\hline$J_{1}$ & - & - & & $\mathbf{M N}_{4}$ & 2,2 & 321 \\
\hline $\mathbf{O O}_{1}$ & 0,7 & 317 & & $\mathbf{M}_{4}$ & 5,5 & 012 \\
\hline $\mathrm{MNS}_{2}$ & - & - & & $\mathbf{S N}_{4}$ & - & - \\
\hline $2 \mathbf{N}_{2}$ & 1,4 & \begin{tabular}{|l|l}
140 \\
\end{tabular} & & MS $_{4}$ & 2,8 & 101 \\
\hline \multicolumn{7}{|c|}{ Referências de Nível: RN Principal - dentro das instalaçōes da estação de pesquisa } \\
\hline \multicolumn{7}{|c|}{$\begin{array}{l}\text { 2. Valores extraídos de informaç̃es direta } \\
\text { de São Paulo (II): 1-14, } 1983 \text { dos professores } \\
3 \text { - Estaçăo do Programa GLOSS }\end{array}$} \\
\hline
\end{tabular}


As Figuras 4.17 e 4.18 apresentam o estudo de maré meteorológica, segundo Harari, com base em dados maregráficos de 1992 e 1993 na Enseada do Flamengo, em Ubatuba. Os níveis estão aproximadamente reduzidos ao zero IBGE.

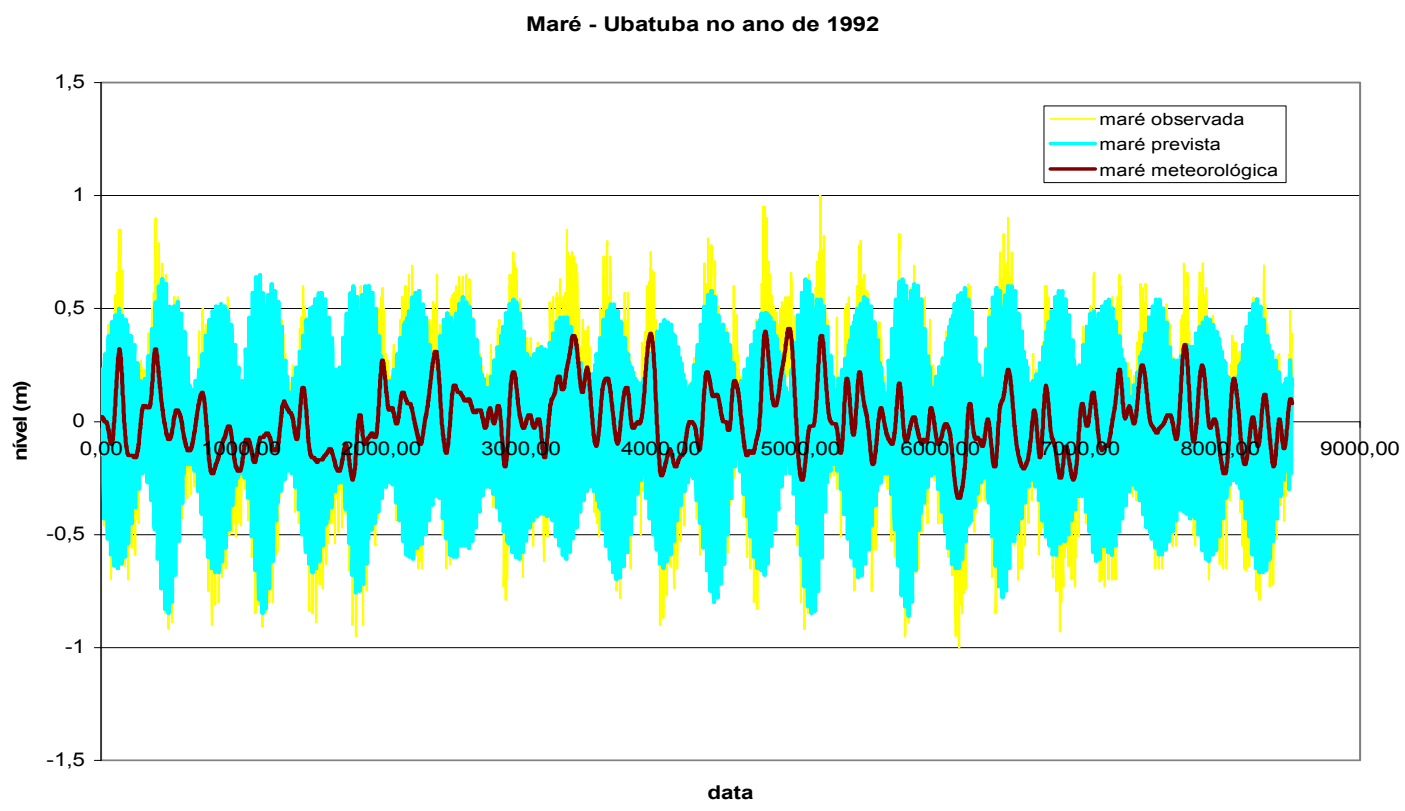

Figura 4.17 Comparação das Marés em Ubatuba no ano de 1992. FONTE: Harari, 1992

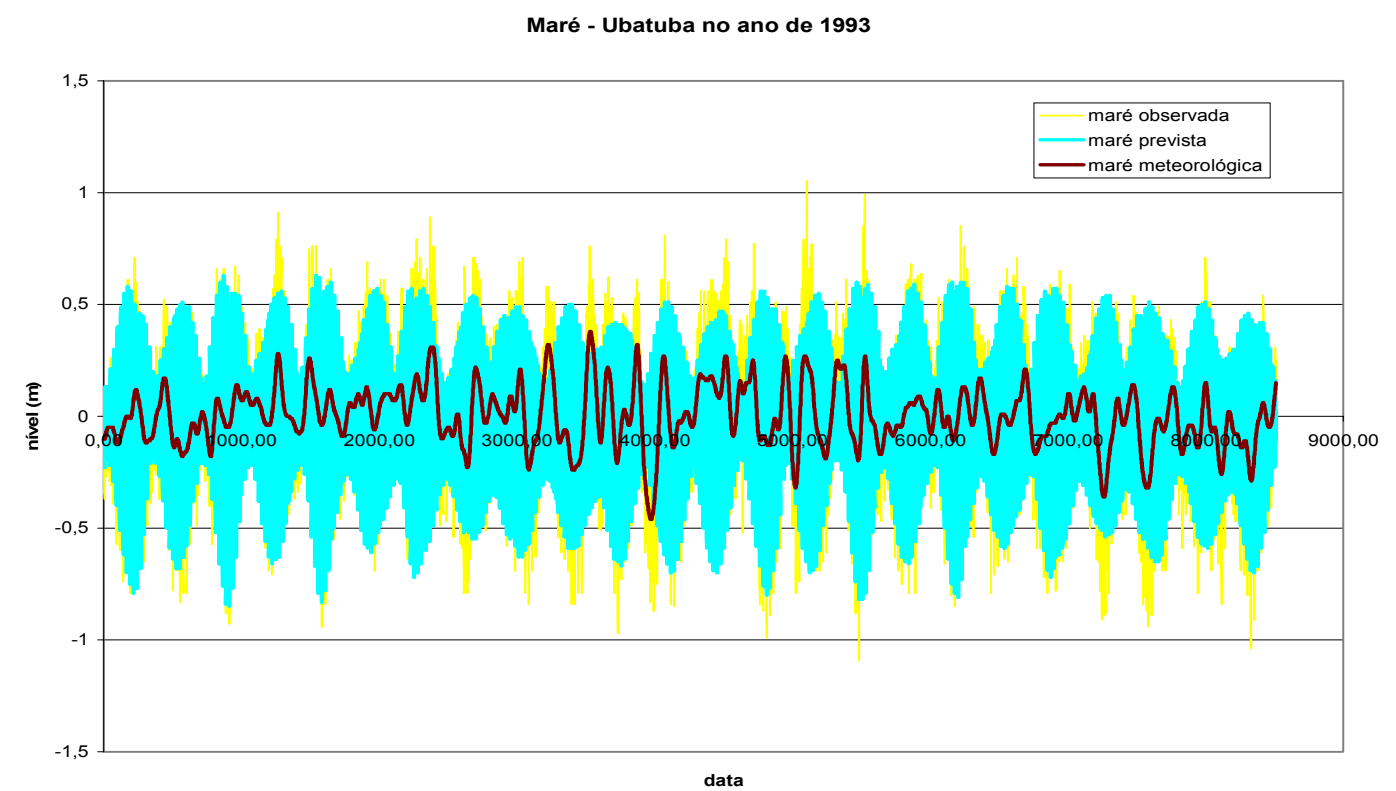

Figura 4.18 Comparação das Marés Ubatuba no ano de 1993. FONTE: Harari, 1993 
Na Costa Paulista, a entrada de frentes frias (ver Figura 4.19) é a maior responsável pelas ressacas, variando o nível médio do mar. Tal efeito associado com o estudo das fichas maregráficas (Tabelas 4.4 e 4.5) e análise dos gráficos de comparação das marés (Figuras 4.17 e 4.18), a sobrelevação da preamar por efeito meteorológico, no início do mês de junho de 2006, na Praia de Massaguaçu, pode ser estimada em $0,30 \mathrm{~m}$.

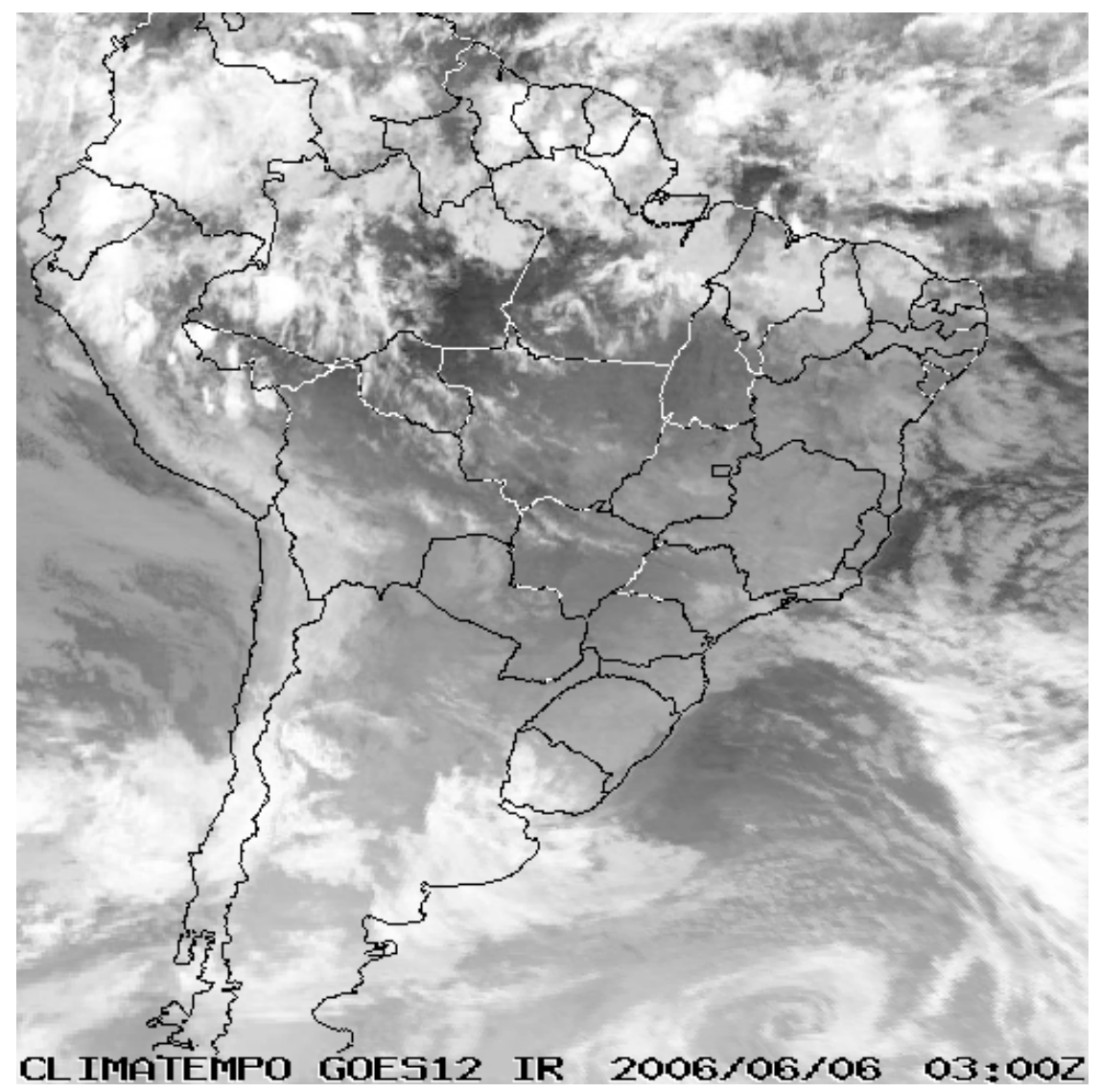

Figura 4.19 Imagem de Satélite da situação meteorológica no dia 06 de junho de 2006.

Com base no estudo de freqüência média de passagem de sistemas frontais pela Costa Sul do Brasil, verifica-se que no período de abril a novembro ocorrem 35 eventos deste tipo, correspondendo a uma média de 4 a 5 eventos por mês, de um total de 46 anuais, enquanto nos meses de verão a freqüência cai para 2 a 3 eventos (Silva, 1972).

Na Tabela 4.6 está apresentada a previsão da maré astronômica no Porto de Santos para os primeiros dias de junho de 2006, já reduzida à cota IBGE. 
Tabela 4.6 Previsão da maré astronômica para o Porto de Santos

PORTO DE SANTOS - TORRE GRANDE (ESTADO DE SÃO PAULO)

Latitude: $23^{\circ} 57^{\prime}, 3$ S Longitude: $046^{\circ} 18^{\prime}, 4$ W Fuso: +03.0 Ano: 2006

Nível Médio: 0.79

Carta: 1701

\begin{tabular}{|c|c|c|c|c|}
\hline Lua & & Dia & Hora & Alt. (m) \\
\hline & \multirow{3}{*}{\multicolumn{2}{|c|}{ QUI 01/06/06 }} & $04: 04$ & 0.4 \\
\hline & & & $12: 45$ & -0.4 \\
\hline & & & $18: 34$ & 0.3 \\
\hline & \multirow{4}{*}{ SEX } & \multirow{4}{*}{$02 / 06 / 06$} & $00: 13$ & 0.0 \\
\hline & & & $04: 36$ & 0.3 \\
\hline & & & $13: 30$ & -0.3 \\
\hline & & & $19: 30$ & 0.3 \\
\hline & & & & \\
\hline & \multirow{4}{*}{ SAB } & \multirow{4}{*}{$03 / 06 / 06$} & $01: 08$ & 0.0 \\
\hline & & & $05: 26$ & 0.2 \\
\hline & & & $14: 15$ & -0.3 \\
\hline & & & $21: 00$ & 0.2 \\
\hline & & & & \\
\hline & \multirow{4}{*}{ DOM } & \multirow{4}{*}{$04 / 06 / 06$} & $03: 08$ & 0.0 \\
\hline & & & $09: 38$ & 0.3 \\
\hline & & & $15: 08$ & -0.3 \\
\hline & & & $23: 00$ & 0.3 \\
\hline & & & & \\
\hline & \multirow{3}{*}{ SEG } & \multirow{3}{*}{$05 / 06 / 06$} & $04: 56$ & -0.1 \\
\hline & & & $10: 34$ & 0.4 \\
\hline & & & $16: 00$ & -0.3 \\
\hline & & & & \\
\hline & \multirow{4}{*}{ TER } & \multirow{4}{*}{$06 / 06 / 06$} & $00: 04$ & 0.3 \\
\hline & & & $05: 38$ & -0.2 \\
\hline & & & $11: 19$ & 0.5 \\
\hline & & & $16: 54$ & -0.3 \\
\hline & & & & \\
\hline & \multirow{4}{*}{ QUA } & \multirow{4}{*}{$07 / 06 / 06$} & $00: 49$ & 0.4 \\
\hline & & & $06: 09$ & -0.4 \\
\hline & & & $12: 02$ & 0.5 \\
\hline & & & $17: 47$ & -0.3 \\
\hline & & & & \\
\hline & \multirow{4}{*}{ QUI } & \multirow{4}{*}{$08 / 06 / 06$} & $01: 24$ & 0.4 \\
\hline & & & $06: 45$ & -0.5 \\
\hline & & & $12: 47$ & 0.6 \\
\hline & & & $18: 36$ & -0.3 \\
\hline
\end{tabular}


O resumo dos níveis máximo e médio das marés, registrado no Banco de Dados do Porto de Santos, para a primeira quinzena de junho de 2006 está apresentado na Tabela 4.7 abaixo.

Tabela 4.7 Resumo dos níveis máximos e do nível médio do Registro das Marés no Porto de Santos para a primeira quinzena de junho

\begin{tabular}{|c|c|c|}
\hline \multicolumn{3}{|c|}{ Junho de 2006 (Porto de Santos) } \\
\hline Dia & $\begin{array}{c}\text { Máxima Cota Diária } \\
\text { (cota IBGE) }\end{array}$ & $\begin{array}{c}\text { Nível Médio do Mar } \\
\text { (cota IBGE) }\end{array}$ \\
\hline 1 & 0,50 & 0,21 \\
\hline 2 & 0,40 & 0,13 \\
\hline 3 & 0,10 & $-0,15$ \\
\hline 4 & $-0,30$ & $-0,46$ \\
\hline 5 & 0,40 & $-0,24$ \\
\hline 6 & 0,60 & 0,22 \\
\hline 7 & 0,50 & 0,13 \\
\hline 8 & 0,60 & 0,11 \\
\hline 9 & 0,40 & $-0,07$ \\
\hline 10 & 0,40 & $-0,17$ \\
\hline 11 & 1,00 & 0,22 \\
\hline 12 & 0,90 & 0,25 \\
\hline 13 & 0,60 & 0,06 \\
\hline 14 & 0,50 & $-0,10$ \\
\hline 15 & 0,60 & 0,02 \\
\hline
\end{tabular}

FONTE: Alfredini, 2006

Portanto, a soma da maré astronômica com a maré meteorológica no dia da ressaca (06/06/2006) foi estimada, analisando toda a bibliografia e os diversos dados, em 0,80 m (zero IBGE), porém ficou constatado que, nessa ocasião, o nível máximo da maré atingiu uma cota de 0,60 m (zero IBGE). 


\subsubsection{Ondas}

As costas centro e sul do Estado de São Paulo apresentam uma faixa litorânea retilínea e arenosa. A costa norte, por sua vez, apresenta um litoral mais recortado, com predomínio de praias arenosas, tendo a presença da llha de São Sebastião que promove abrigo em largo trecho do litoral das ondas provindas de mar aberto, entretanto a condição de vento local é suficiente para a manutenção de um clima de ondas curtas energético, mesmo nas zonas de sombra.

Definir adequadamente a onda significativa a ser utilizada nos cálculos de obras marítimas é essencial. A altura da onda é normalmente o fator mais importante no projeto. Considerar uma onda excessivamente conservativa pode encarecer o custo de uma obra e pode torná-la até mesmo inviável economicamente. Ao contrário, subestimar a altura da onda pode resultar no colapso da obra, comprometendo até mesmo vidas humanas, ou incorrendo em custos de manutenção muito altos.

A norma brasileira NBR 9782 de março de 1987 é responsável pela fixação de valores representativos das ações ambientais que devem ser consideradas no projeto de estruturas marítimas e portuárias relativamente às ondas. A norma define os principais parâmetros que definem a altura da onda, mas não aconselha nenhum procedimento. A norma considera que o período de recorrência da onda de projeto não seja inferior ao da expectativa da vida útil da obra, no mínimo 50 anos.

A onda significativa (Hs), por definição, é a média aritmética das alturas do terço superior das ondas registradas, através de equipamentos específicos, os ondógrafos, no banco de dados do local estudado.

O período de retorno é um conceito que pode ser definido como o intervalo médio da ocorrência em que um parâmetro pode ser igualado ou excedido.

Uma vez calculado o período de retorno para determinada altura de onda, não significa que obrigatoriamente esta onda ocorra periodicamente a cada intervalo de período de retorno, mas que em média este é o intervalo em que a onda pode ser igualada ou superada.

A Tabela 4.8 apresenta as probabilidades percentuais da altura significativa igualar ou exceder determinado período de retorno. 
Tabela 4.8 Probabilidade da Altura da Onda Significativa igualar ou exceder a Onda de Projeto durante a vida útil da obra

\begin{tabular}{|c|c|c|c|c|c|c|}
\hline $\begin{array}{c}\text { Período de Retorno } \\
\text { considerado no Projeto } \\
\text { (anos) }\end{array}$ & \multicolumn{6}{|c|}{ Período de tempo considerado de vida útil da obra } \\
(anos)
\end{tabular}

Nos projetos de obras costeiras e portuárias é necessário considerar condições extremas, pois um único evento pode levar ao colapso e perda total da estrutura.

O CEM - Coastal Engineering Manual - U.S. Army Corps of Engineers (2002) - recomenda as funções de Gumbel, também conhecida como Fisher-Tippett Tipo I, e Weibull para serem usadas como funções de distribuição de probabilidades para a estimativa das alturas de ondas significativas extremas. Além destas duas recomendadas pelo CEM costuma-se utilizar a distribuição Log-Normal e Exponencial. As equações de 4.1 a 4.4 apresentam as distribuições de probabilidades acumuladas de Gumbel, Weibull, Log-Normal e Exponencial.

Gumbel ou Fisher-Tippett Tipo I

$$
F(x)=e^{-\left(\frac{x-8}{2}\right)}
$$

Weibull

$$
F(x)=1-e^{-\left(\frac{x-g}{\lambda}\right)}
$$

Log-Normal

$$
F(x)=\frac{1}{\sqrt{2 \pi}} \int_{0}^{x} \frac{1}{\sigma \cdot x} \cdot e^{\left(-\frac{1}{2}\left(\frac{\ln x-\mu}{\sigma}\right)^{2}\right)} d x
$$


Exponencial: caso particular da distribuição de Weibull quando $c=1$

$$
F(x)=1-e^{\left(\begin{array}{c}
x-6 \\
2
\end{array}\right)}
$$

Onde:

c: parâmetro de forma da distribuição de probabilidade;

$\theta$ e $\boldsymbol{\mu}$ : parâmetros de locação da distribuição de probabilidade;

$\lambda$ e $\boldsymbol{\sigma}$ : parâmetros de escala da distribuição de probabilidade;

Devido ao fato do registro de ondas, do local estudado - Praia de Massaguaçu, ser muito reduzido, é necessário trabalhar com os dados obtidos em localidades próximas. Segundo estudos de Alfredini (2006), os dados do BNDO Banco Nacional de Dados Oceanográficos do Subquadrado MARSDEN 37634 e 37644 - são os mais próximos da Praia de Massaguaçu (ver Figura 4.20). Foram consultados os dados de 1962 a 1996 (período com dados disponíveis para as áreas) e elaborados os gráficos de valores médios anuais das alturas de ondas significativas e rumos de proveniência (Figuras 4.21 a 4.24). Estes dados referem-se a observações visuais em águas profundas no período de 1978 a 1985, época em que se coletaram, em média, mais de 100 observações anuais, o que confere maior consistência estatística aos dados.

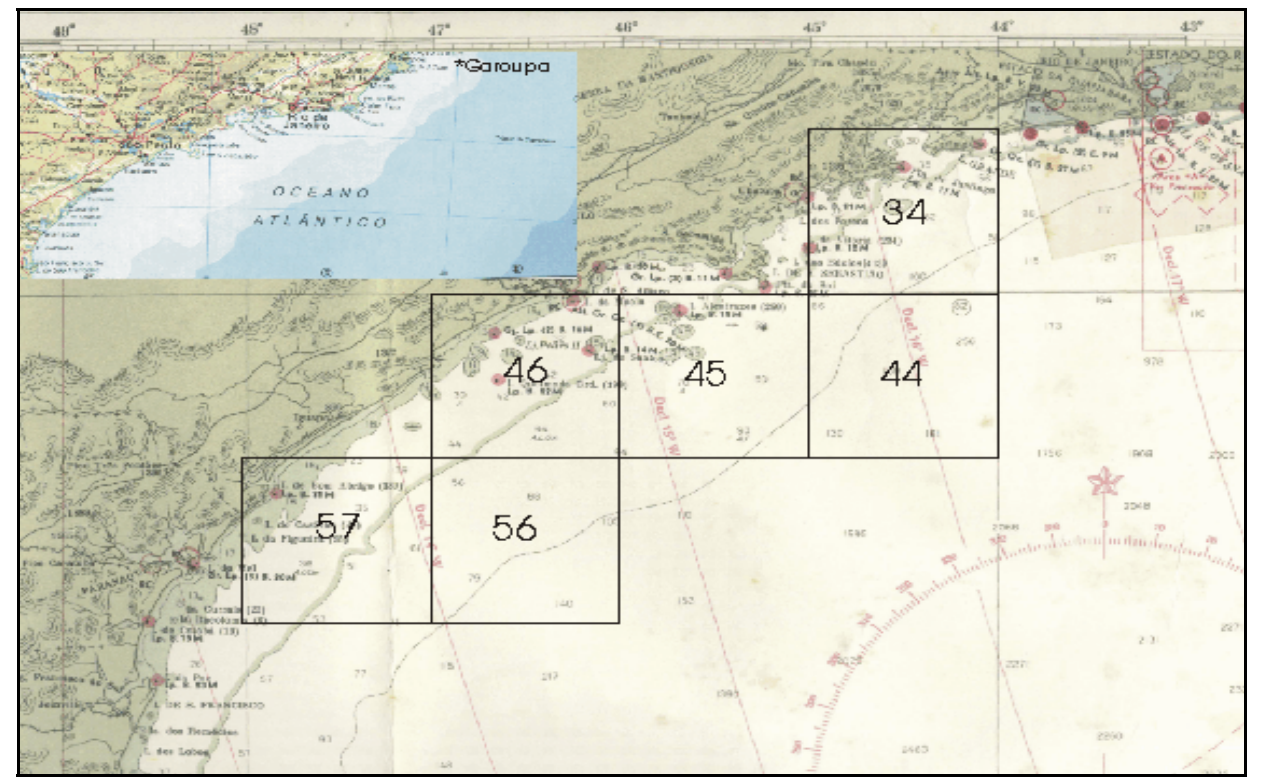

Figura 4.20 Subquadrados do Quadrado 376 de MARSDEN para a Costa de São Paulo 
Rumo - Quadrícula 34

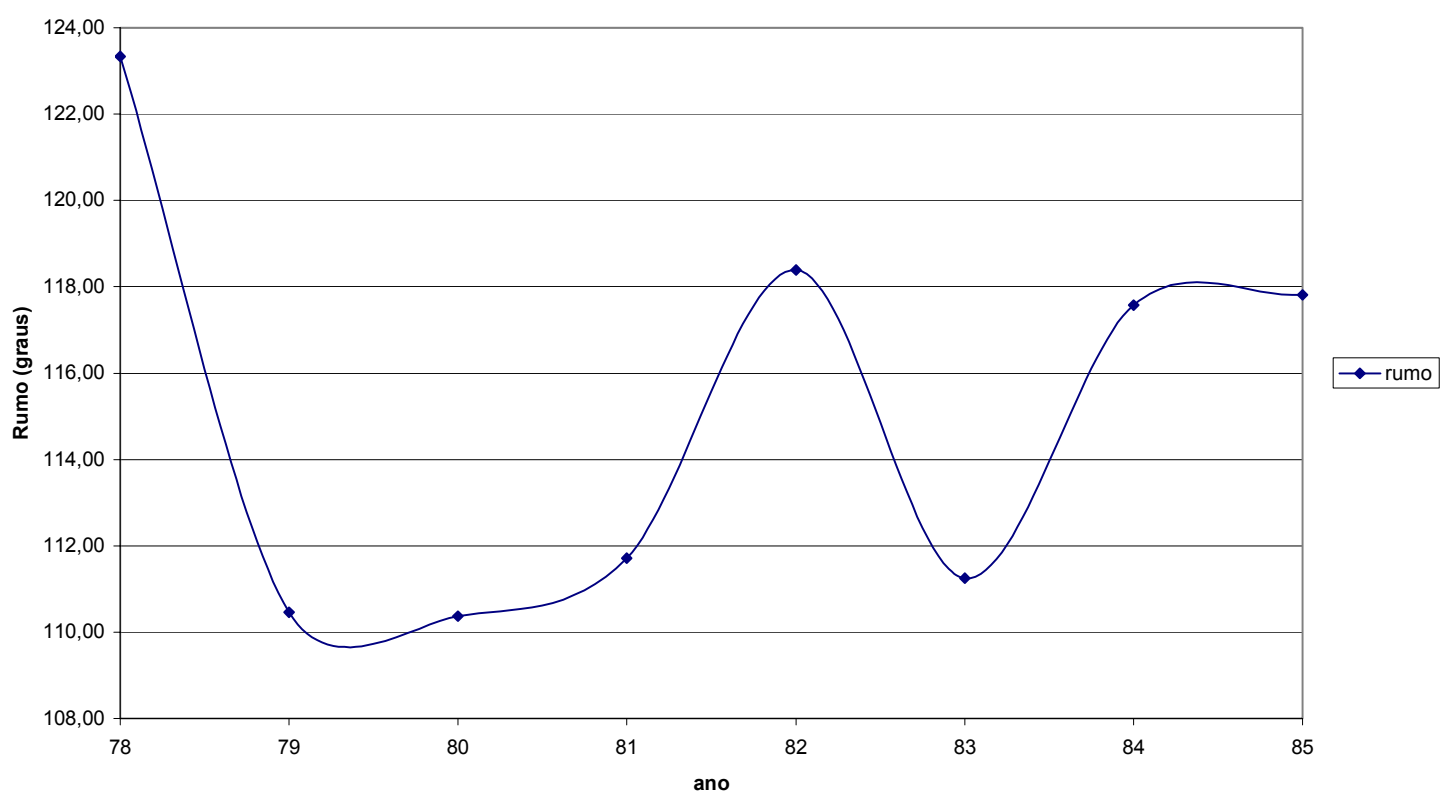

Figura 4.21 Rumos com NV (Norte Verdadeiro) da agitação no Subquadrado MARSDEN 37634 FONTE: Alfredini, 2006

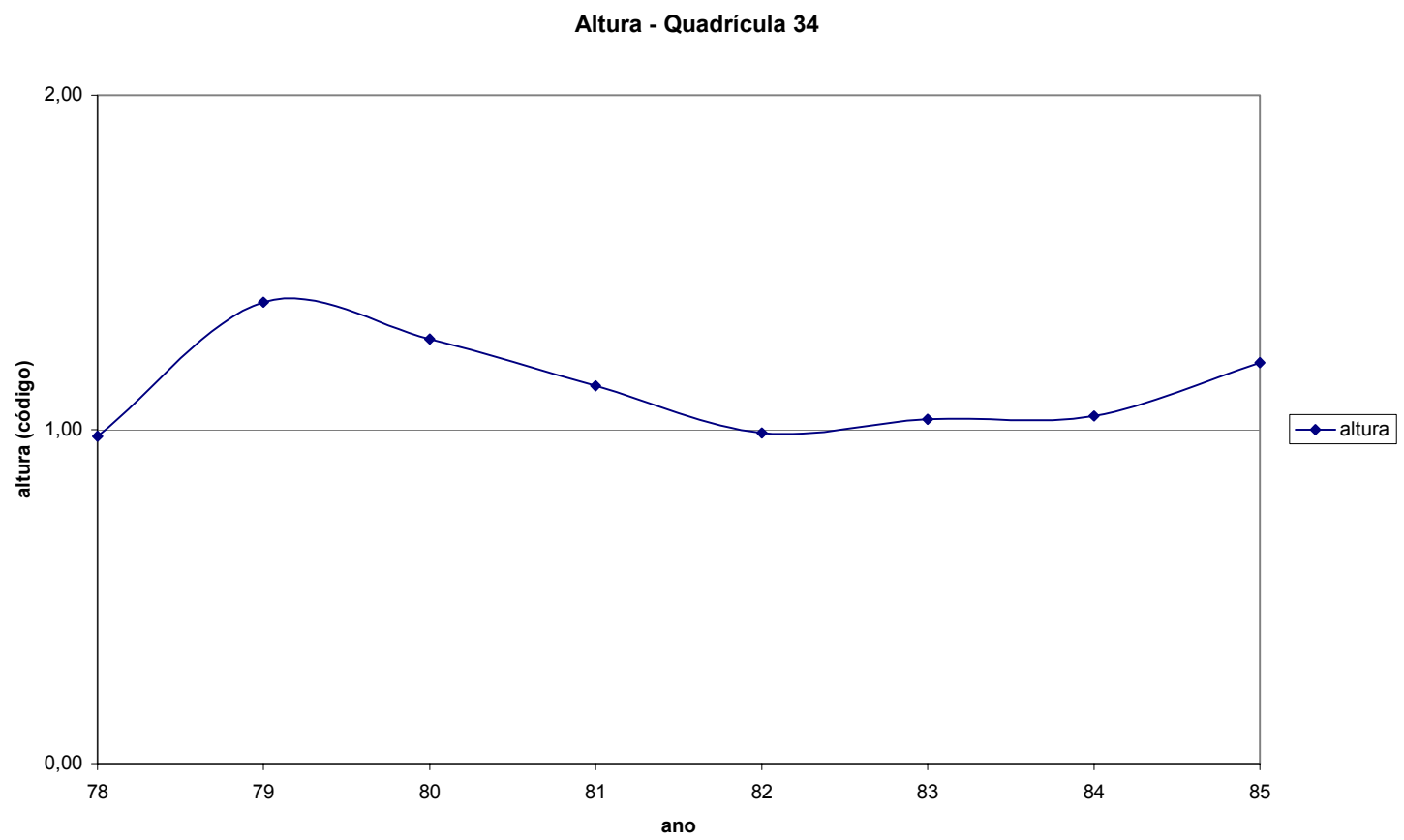

Figura 4.22 Alturas Significativas da agitação no Subquadrado MARSDEN 37634 FONTE: Alfredini, 2006 
Rumo - Quadrícula 44

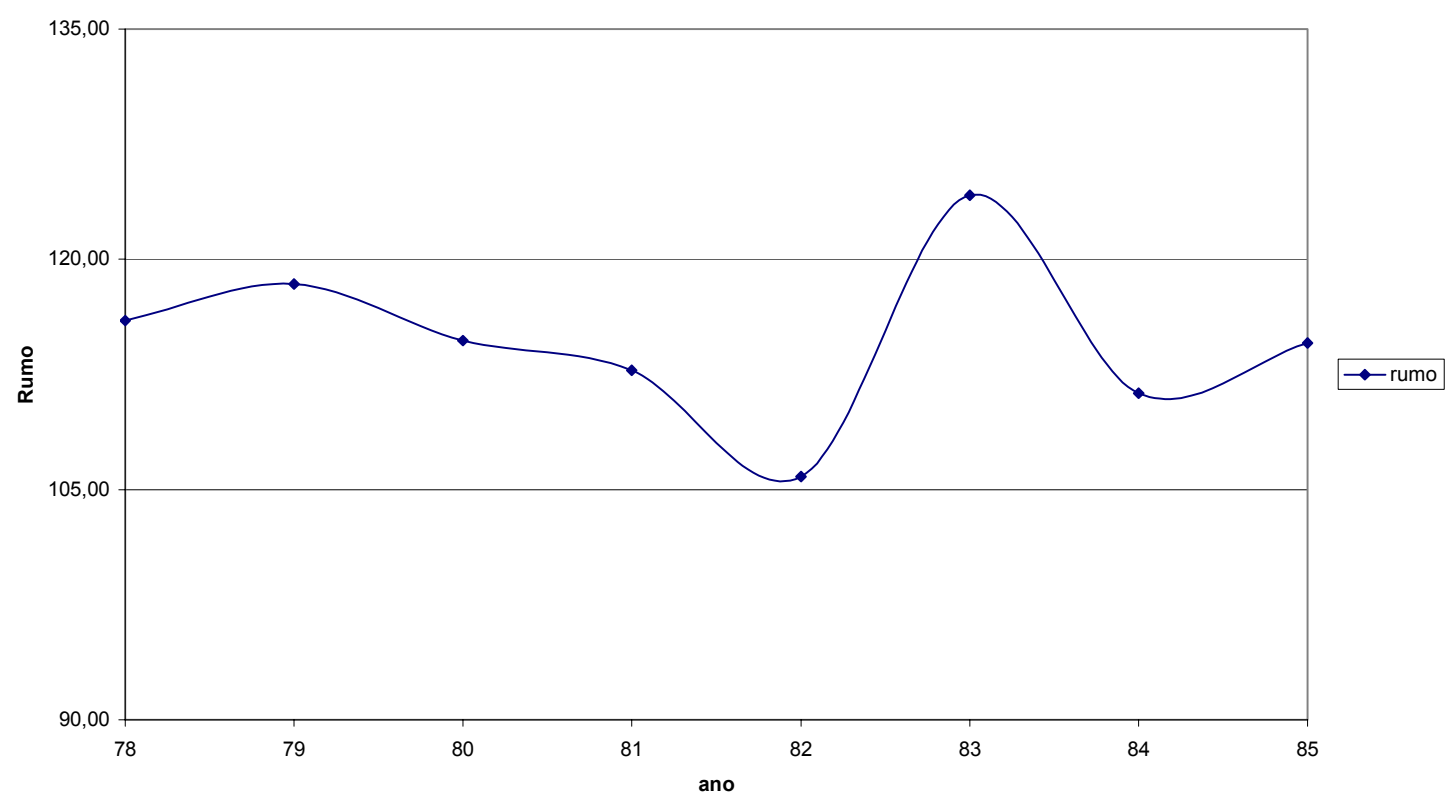

Figura 4.23 Rumos com NV (Norte Verdadeiro) da agitação no Subquadrado MARSDEN 37644 FONTE: Alfredini, 2006

Altura - Quadrícula 44

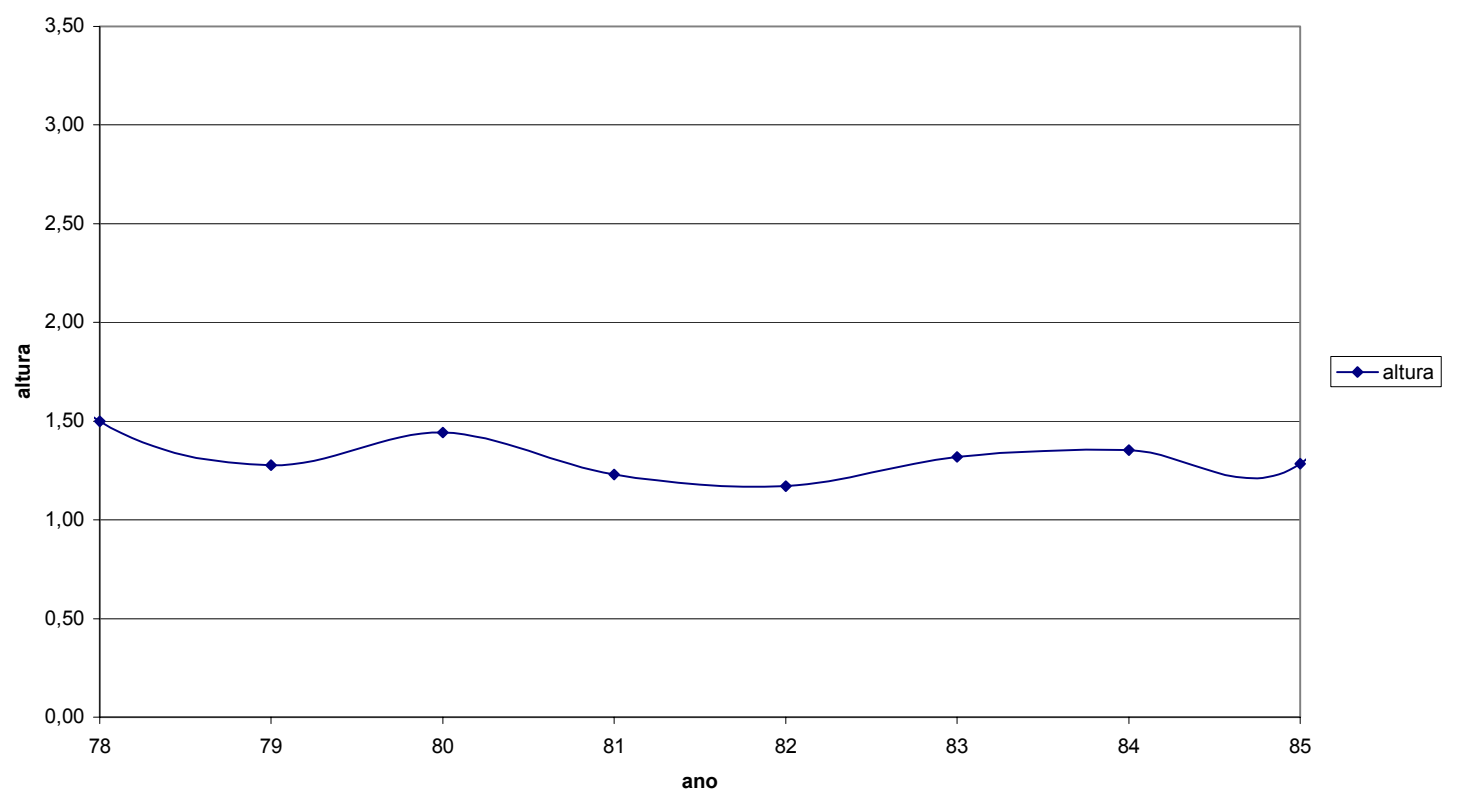

Figura 4.24 Alturas Significativas da agitação no Subquadrado MARSDEN 37644 FONTE: Alfredini, 2006

Observa-se nitidamente uma dominância dos rumos de $\operatorname{ESE}\left(101,25^{\circ}\right.$ a $123,75^{\circ} \mathrm{NV}$ ), em função das condições meteorológicas e do recorte topográfico da costa e das ilhas, especialmente a de São Sebastião, conforme pode ser observado 
nas Figuras 4.25 e 4.26, quanto à propagação de ondas de E e SE (Alfredini, 2005). Quanto às alturas significativas médias anuais, oscilam de 1,00 a 1,50 m.



Figura 4.25 Ortogonais de propagação de Onda de $\mathrm{E}$ FONTE: Alfredini, 2005

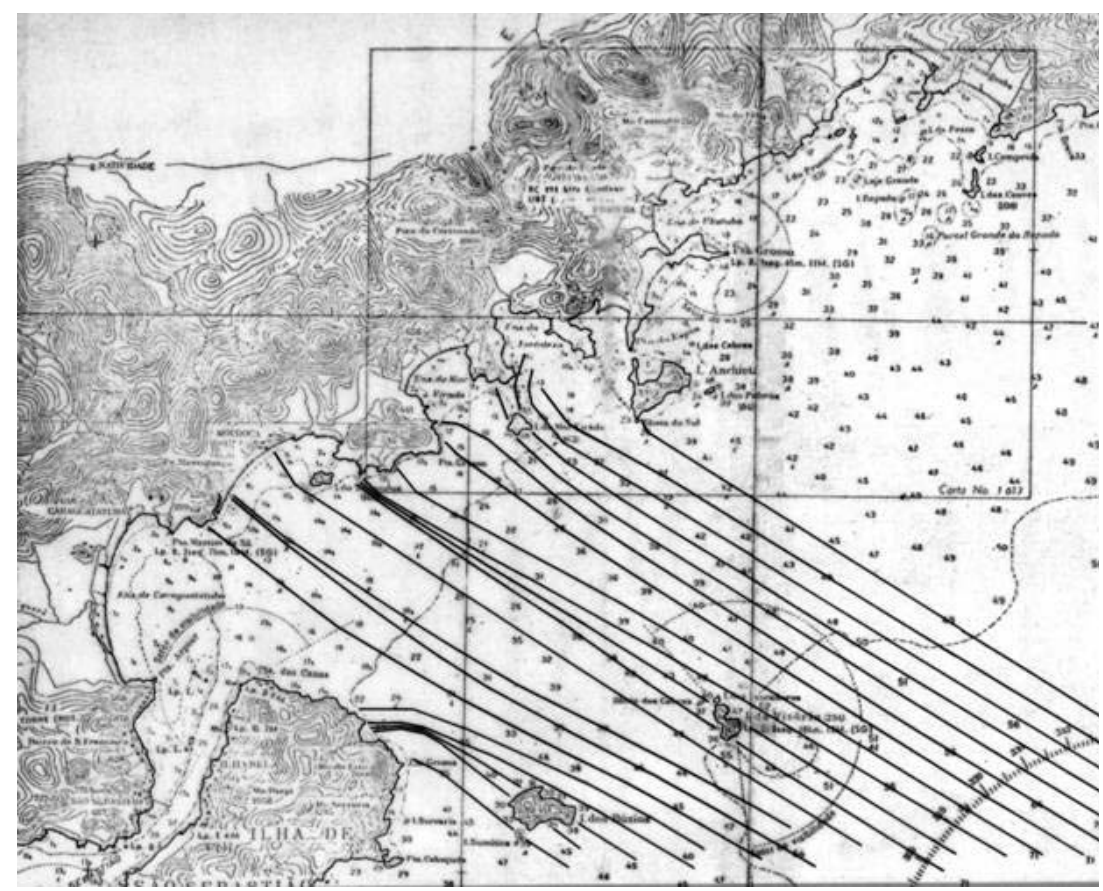

Figura 4.26 Ortogonais de propagação de Onda de SE FONTE: Alfredini, 2005 
Araújo (2005) fez um estudo das rosas de ondas da altura significativa média anual para várias localidades. A Figura 4.27 representa à rosa de ondas da Praia de Massaguaçu, e pode ser observado que a ação da agitação das ondas é eminentemente ortogonal à praia.

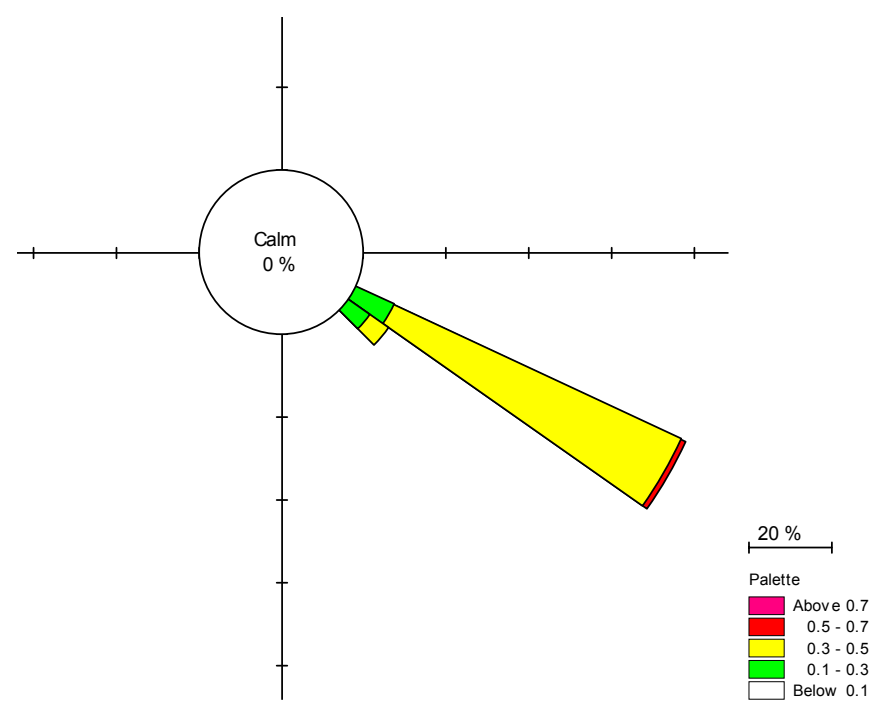

Figura 4.27 Rosa de Ondas - Altura Significativa $(\mathrm{m})$ média anual FONTE: Araújo, 2005

A base de dados de clima de ondas da Praia do Una, na Juréia, é a mais longa da costa do Estado de São Paulo, abrangendo os anos de 1982 a 1985. Araújo (2005) apresentou a retro-refração destes dados para águas profundas, apresentando a Tabela 4.9, que fornece as características médias anuais das condições climáticas.

Tabela 4.9 Dados de Onda em Águas Profundas

\begin{tabular}{|c|c|c|c|}
\hline $\begin{array}{c}\text { Rumo em graus } \\
\text { NV }\end{array}$ & $\begin{array}{c}\text { Altura Significativa } \\
(\mathrm{m})\end{array}$ & $\begin{array}{c}\text { Período Médio } \\
(\mathrm{s})\end{array}$ & $\begin{array}{c}\text { Ocorrência } \\
(\%)\end{array}$ \\
\hline 101,57 & 1,38 & 7,42 & 1,41 \\
\hline 107,5 & 1,16 & 7,95 & 0,96 \\
\hline 110,83 & 1,1 & 9,06 & 1,19 \\
\hline 120,13 & 1,23 & 7,38 & 3,06 \\
\hline 125,9 & 1,22 & 6,93 & 5,11 \\
\hline 127,8 & 0,9 & 6,58 & 4,01 \\
\hline 138,7 & 1,29 & 7,7 & 10,4 \\
\hline
\end{tabular}




\begin{tabular}{|c|c|c|c|}
\hline 147,5 & 1,36 & 7,3 & 4,06 \\
\hline 167,6 & 1,59 & 8,36 & 1,6 \\
\hline 188,2 & 1,67 & 8,07 & 1,05 \\
\hline
\end{tabular}

FONTE: Araújo, 2005

Observa-se que os dados de alturas significativas dos primeiros 5 setores de rumos (ESE) são coerentes com os apontados pelo BNDO (entre 1,00 e 1,50 m), correspondendo a um período médio de 7,8 s.

Araújo (2005) estudou a propagação dessas ondas, e com a utilização do software Mike $21 \mathrm{NSW}$, criou uma série temporal contínua de ondas para a base de dados de 3 anos para a Juréia. Os resultados estão ilustrados nas Figuras 4.28 e 4.29, e podemos observar que as ondas significativas médias anuais nas proximidades da Praia de Massaguaçu podem atingir de 1,00 a 1,25 m de altura.

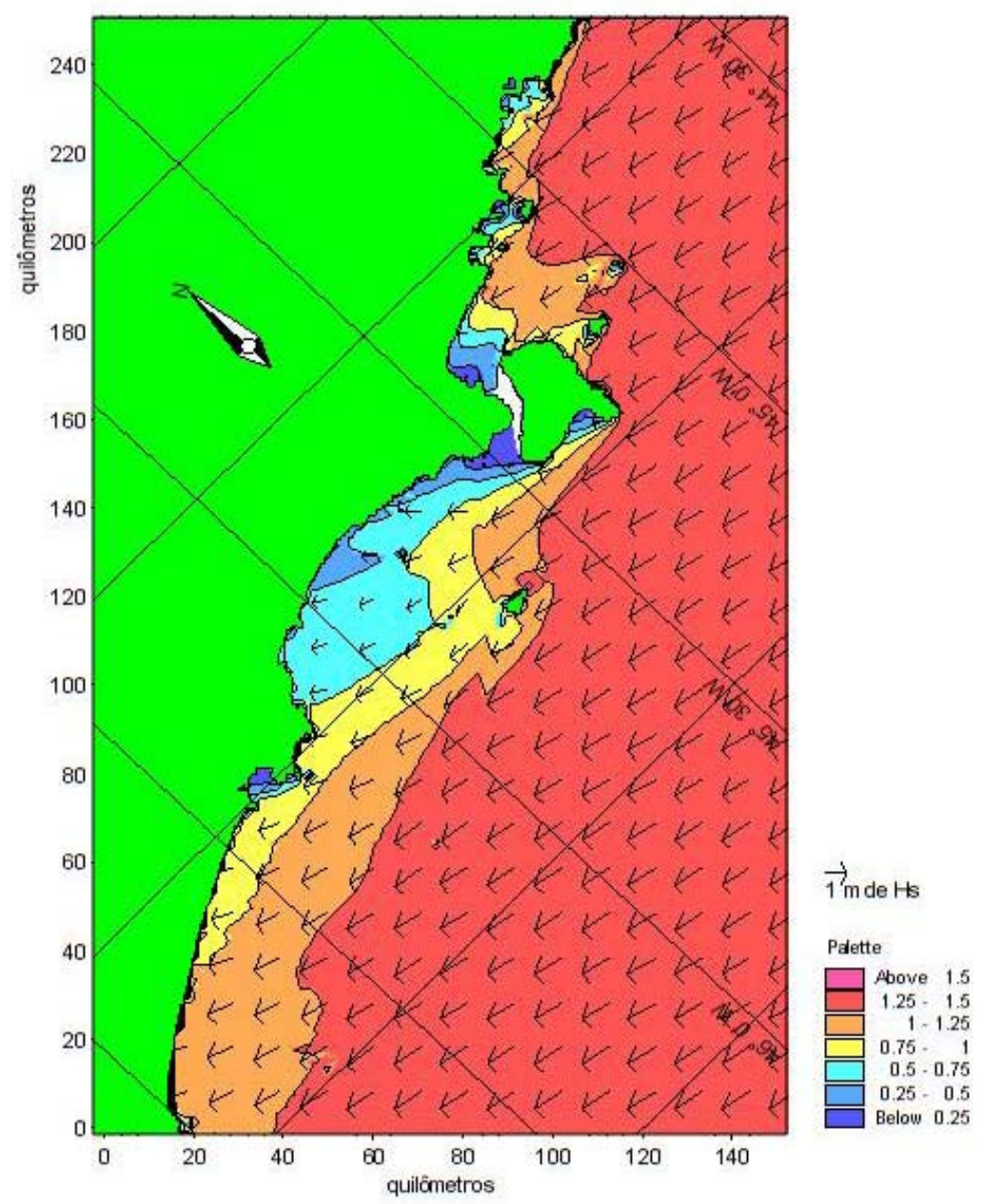

Figura 4.28 Altura Significativa para onda em águas profundas com rumo de $101,57^{\circ}$, altura significativa de $1,38 \mathrm{~m}$ e período médio de $7,42 \mathrm{~s}$.

FONTE: Araújo, 2005 


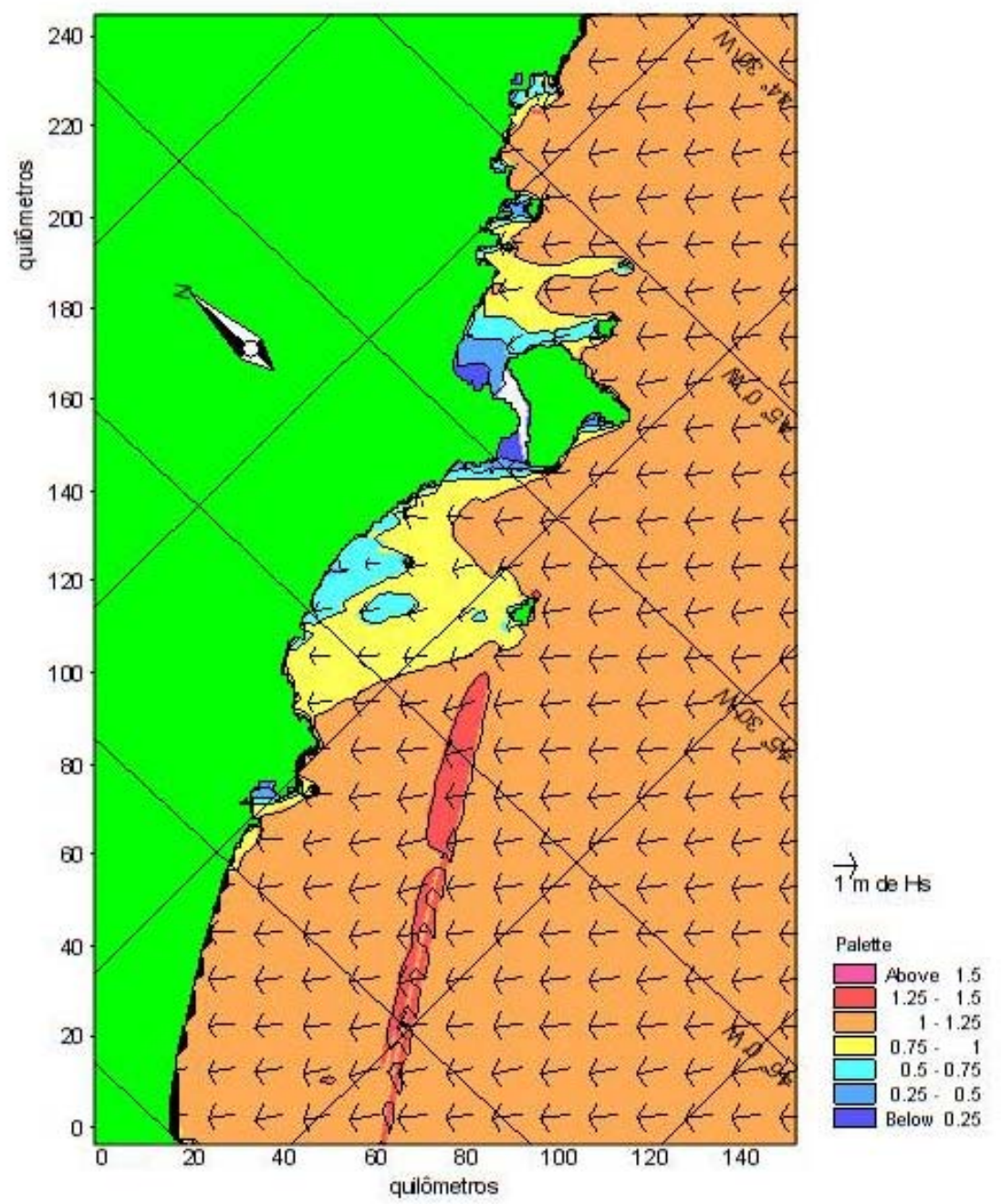

Figura 4.29 Altura Significativa para onda em águas profundas com rumo de $125,9^{\circ}$, altura significativa de $1,22 \mathrm{~m}$ e período médio de $6,93 \mathrm{~s}$.

FONTE: Araújo, 2005

Com base nesta série histórica, estimaram-se as alturas das ondas significativas para 1, 5, 10 e 50 anos de período de retorno, em água profunda, em 3,50 m, 4,40 m, 4,70 m e 5,40 m, respectivamente (Araújo \& Alfredini, 2005).

A Figura 4.30 retrata o modelo de previsão de altura de onda para a situação climática no mundo. Para o dia 6 de junho de 2006, no litoral do Estado de São Paulo, prevalece ondas significativas entre 1,00 e 2,00 m de altura, valor coerente com todos os dados anteriores. 
Altura Significativa (m) e Direção da Onda INPE/CPTEC/MCT Climatologia para o dia 06 de Junho

WATCH/Global

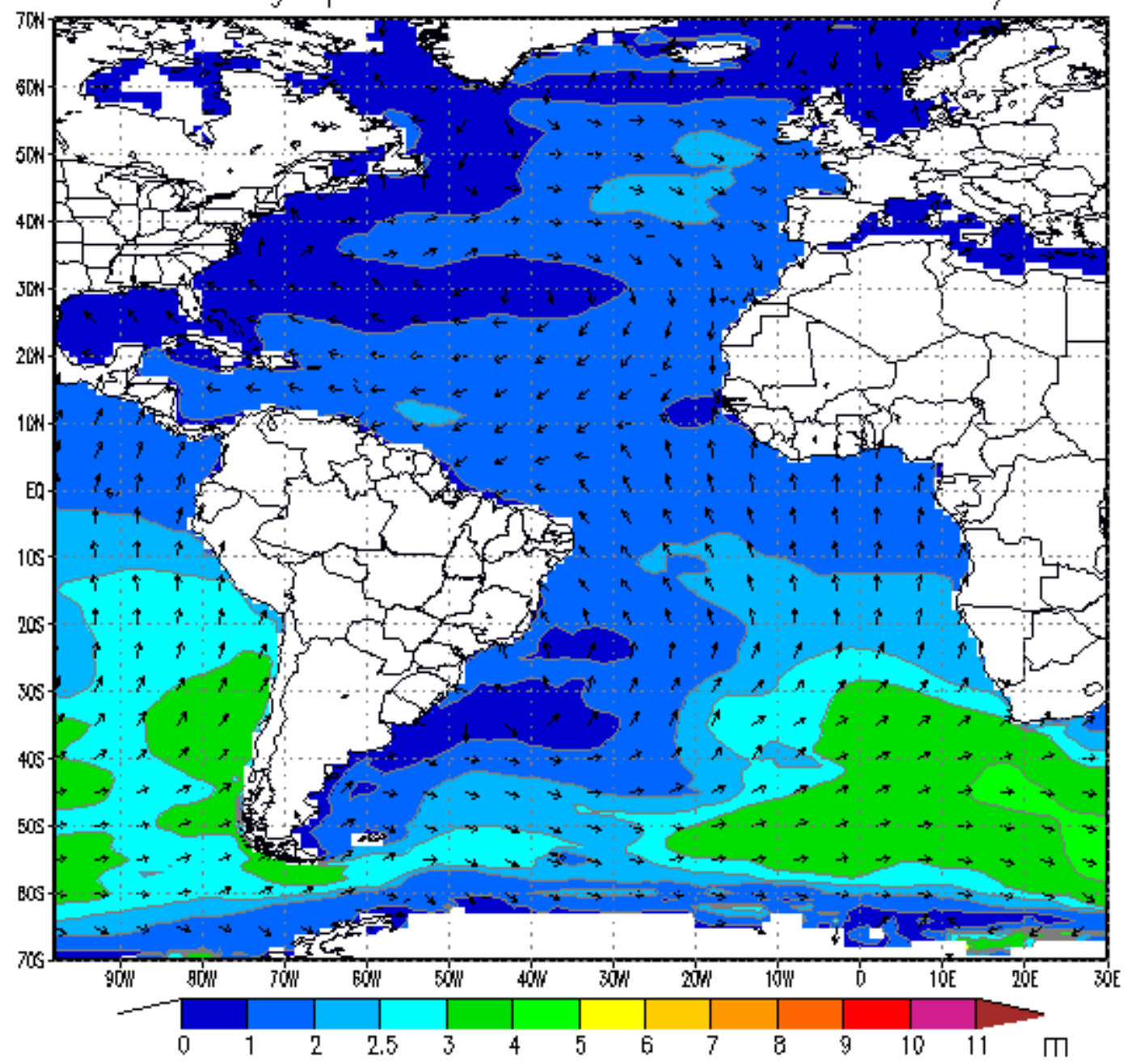

Figura 4.30 Modelo de previsão de altura de onda para a situação climática

Medições com ondógrafo em profundidade de $10 \mathrm{~m}$, em maio de 2002, na Enseada da Fortaleza, nas proximidades da Praia de Massaguaçu, forneceram altura significativa máxima mensal de 2,30 m e significativa média mensal de 0,80 m, com período de pico (Tp) de $12 \mathrm{~s}$ e período médio (Tz) de 9,6 s (Martins, 2005). Em se tratando de dados de apenas 1 mês, observa-se coerência com a ordem de grandeza apontada pelos estudos anteriores, tendo em vista tratar-se somente das observações de um período limitado.

A Figura 4.31 mostra um perfil transversal típico da Praia de Massaguaçu, considerando cotas da DHN da Marinha do Brasil. 


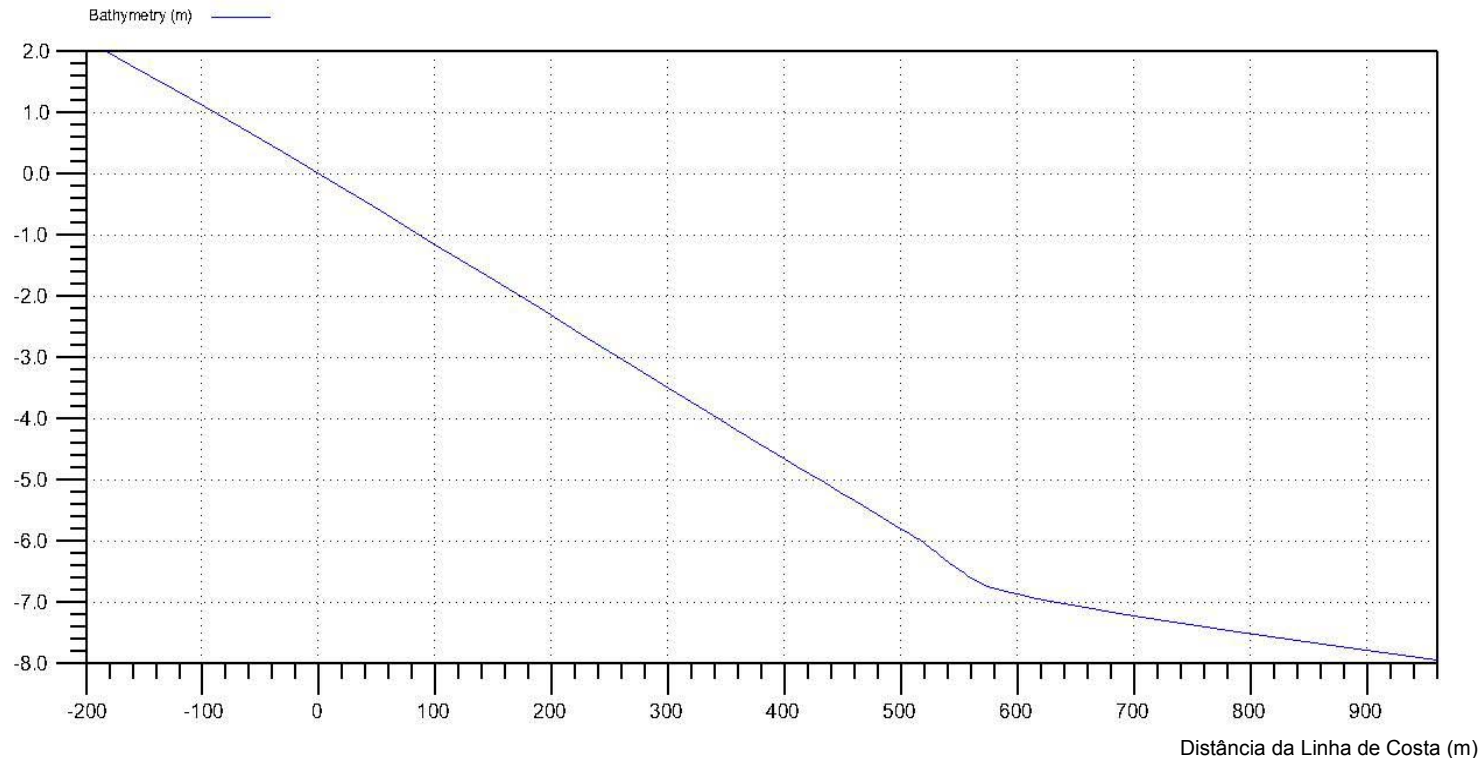

Figura 4.31 Perfil transversal típico da Praia de Massaguaçu FONTE: Araújo, 2005

Com o auxílio do software Mike 21 NSW, Araújo (2005) efetuou simulações (Figura 4.32) a partir dos dados médios de uma onda "qualquer" ( $\mathrm{Hs}=0,33 \mathrm{~m}, \mathrm{~T}=$ 6,8 s e rumo de $124^{\circ} \mathrm{NV}$ ) para demonstrar a alteração do perfil praial frente a uma condição ondulatória, por um período de 10 dias.

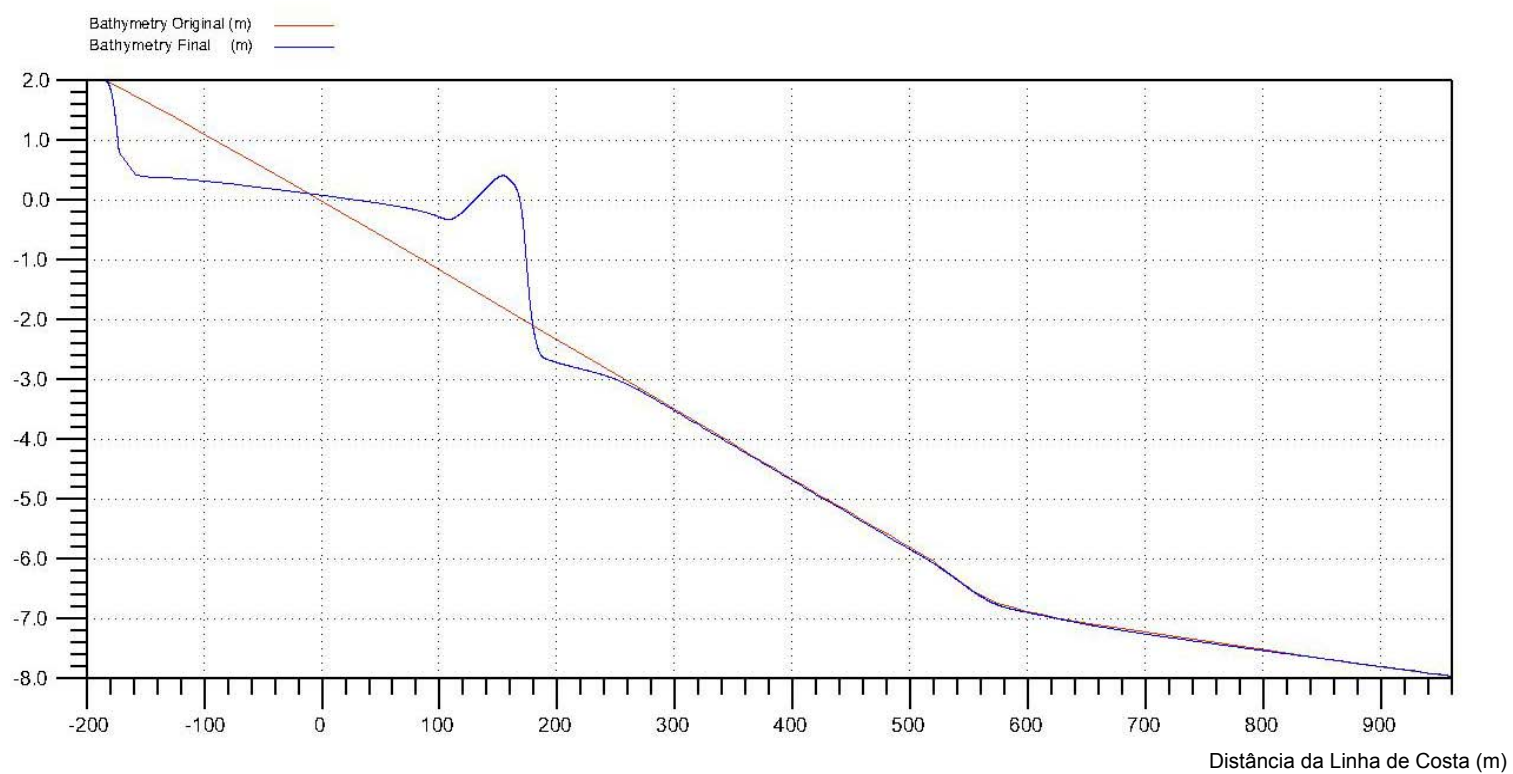

Figura 4.32 Perfil calculado para a onda média atuando durante 10 dias na Praia de Massaguaçu FONTE: Araújo, 2005 
Pode-se notar o retrabalhamento típico que ocorre no perfil da zona de arrebentação e espraiamento da onda, mesmo com uma onda de tão modestas dimensões (Hs=0,33 m).

Assim, é necessário considerar qual a altura da onda de projeto no âmbito da funcionalidade da obra, em função do período de retorno e da vida útil da obra.

Analisando todos os estudos anteriores e os dados levantados constata-se que na zona de arrebentação da Praia de Massaguaçu foram possíveis ondas significativas de, pelo menos, 1,25 $\mathrm{m}$ de altura.

Em situação de fortes tempestades, a altura da onda significativa pode facilmente alcançar de 2 a 3 vezes a altura da onda significativa média observada em condições de bom tempo (Araújo, 2005; Alfredini, 2006) .

Portanto, dentro da descrição do evento ocorrido no dia 6 de junho de 2006, e que produziu grande impacto nas obras de implantação de proteção da Rodovia SP55 , estima-se ondas significativas de, pelo menos, 2,50 m de altura.

\subsubsection{Verificação - Espraiamento}

A análise do evento ocorrido no início do mês de junho de 2006 indica que o mar atingiu a cota de 5,00 m (IBGE) pelo menos, uma vez que enxovalhou a pista da Rodovia SP-55, que está nessa mesma cota em relação ao nível do mar (zero IBGE).

Considerando que a maré atingiu a cota 0,60 $\mathrm{m}$ (zero IBGE) e a onda significativa possa ter alcançado $2,50 \mathrm{~m}$ de altura, o espraiamento dessa onda deverá ser de, no mínimo, 4,40 m, com relação ao nível da maré.

A Figura 4.33 ilustra o processo erosivo análogo ao ocorrido na Praia de Massaguaçu na ressaca do início do mês de junho de 2006. Observe que o recuo do perfil praial após o ataque das ondas de ressaca pode ser superior à dezena de metros. 


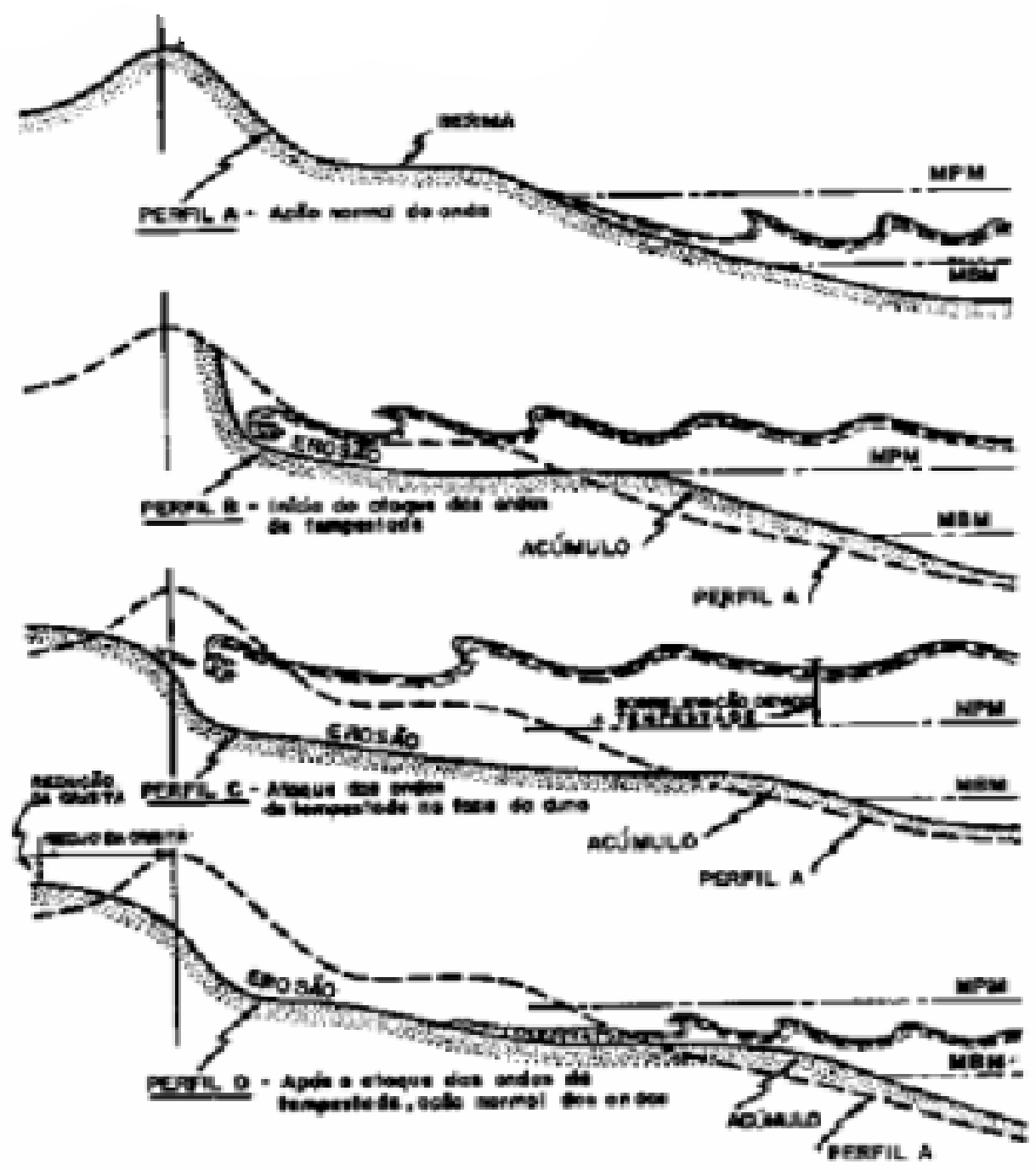

Figura 4.33 Diagrama Esquemático do ataque de Onda de Tempestade na praia e pós-praia FONTE: U.S.Army, 1984

Espraiamento (Runup) é a máxima elevação da água no perfil praial, medido a partir do nível do mar de referência adotado, portanto trata-se de uma sobrelevação do nível do mar (ver Figura 4.34). A previsão precisa de espraiamento para projetos costeiros ainda não está totalmente disponível, devido principalmente a não linearidade da transformação de ondas, reflexões de ondas, efeitos tridimensionais, porosidade, rugosidade, permeabilidade e elevação do aqüifero. Assim, a sua estimativa é obtida principalmente a partir de resultados experimentais obtidos em laboratório, como os apresentados em U.S. Army (1984). 


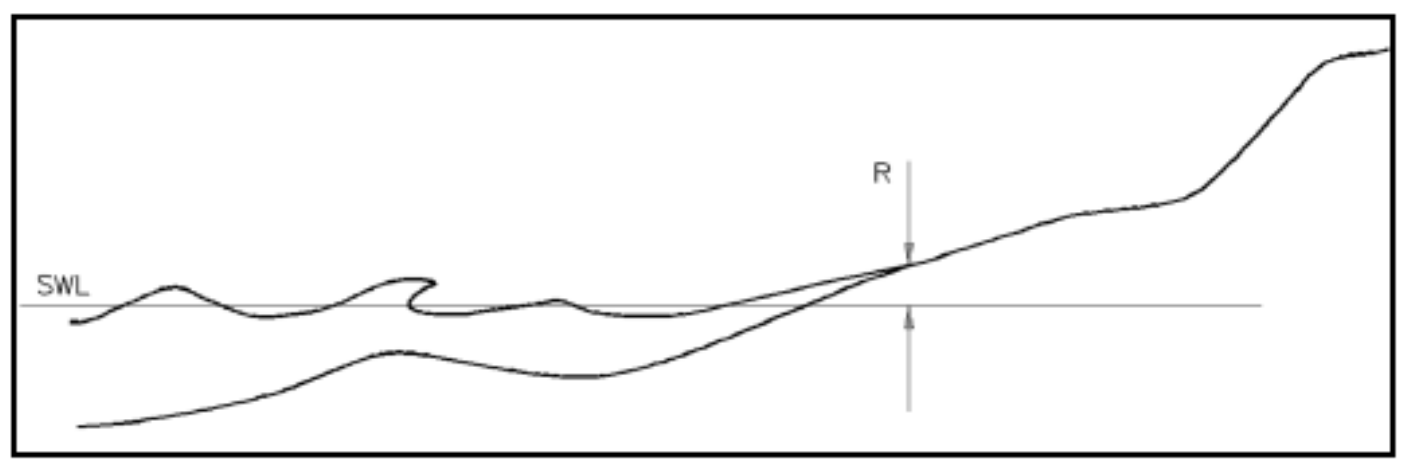

Figura 4.34 Definição de Espraiamento, medido a partir do nível do mar FONTE: U.S.Army, 1984

O espraiamento é função do ângulo de incidência da onda sobre o perfil e geometria do talude (declividade, rugosidade e porosidade). É importante distinguir taludes impermeáveis de taludes permeáveis. Taludes impermeáveis são estruturas revestidas por materiais como, por exemplo, asfalto, concreto ou enrocamento sem a presença de camadas de filtro. Taludes permeáveis são tipicamente os enrocamentos com a presença de camadas de filtro de transição. Deve-se também considerar na estimativa do espraiamento a distribuição estatística das ondas de tempestade no projeto adotada.

Para o cálculo do espraiamento foram contemplados dois métodos: Shore Protection Manual (Manual de Proteção de Praia) e Coastal Engineering Manual (Manual de Engenharia Costeira).

O primeiro método, Shore Protection Manual, é todo baseado em ábacos. É necessário primeiro definir parâmetros como altura da onda $\left(H_{0}\right)$, período $(T)$, declividade $(\tan \beta)$. Depois, com a ajuda dos ábacos, encontra-se o espraiamento (Runup). Posteriormente, define a correção do fator de efeito de escala. E também se pode trabalhar com a correção devido ao material utilizado $\left(\gamma_{R}\right)$.

$\mathrm{O}$ segundo método segue a metodologia adotada pelo Coastal Engineering Manual. A formulação proposta é de Massie (1982), baseado em dados experimentais, para praias impermeáveis. A formulação está relacionada abaixo de 4.5 a 4.8 .

$$
\xi o=\tan \beta\left(\frac{H o}{L o}\right)^{-\frac{1}{2}}
$$




$$
\begin{gathered}
L o=\frac{g \cdot T^{2}}{2 \pi} \\
\frac{R_{\max }}{H o}=2,32 . \xi 0^{077} \\
\frac{R_{2 \%}}{H o}=1,86.50^{0,71}
\end{gathered}
$$

Onde:

$\tan \beta=$ declividade;

$H_{0}=$ altura da onda em águas profundas;

$L_{0}=$ comprimento da onda em águas profundas;

$g=$ aceleração devido à gravidade;

$T=$ período da onda;

$R=$ Runup - espraiamento.

No evento do dia 6 do mês de junho de 2006, temos que a declividade da praia era de $1 \mathrm{~V}: 6 \mathrm{H}$, e o nível da maré na ocasião chegou em 0,60 m (IBGE), com ondas de 2,5 $\mathrm{m}$ de altura em águas profundas e período de 7,8 $\mathrm{s}$.

Os cálculos foram desenvolvidos tanto pela metodologia do Shore Protection Manual, quanto pelo Coastal Engineering Manual, e apesar da falta de precisão temos que o valor do espraiamento foi, respectivamente, de $4,25 \mathrm{~m}$ e 4,75 m, com relação ao nível da maré.

Portanto, verificamos que a onda de projeto a ser considerada, necessariamente precisa ter 2,50 m de altura, no mínimo, para garantir a integridade física da obra e evitar custos de manutenção e reparos muito altos, principalmente em ocasiões de eventos extremos, como esse ocorrido em junho de 2006.

\subsubsection{Projeto}

A obra costeira em análise é uma estrutura longitudinal aderente constituída por um revestimento de alto da praia, situado no pós-praia, mas que é atingido pelo 
espraiamento de ondas, cuja atuação hidrodinâmica é a principal condição de projeto a ser considerada.

Quando da execução do projeto de obras costeiras e portuárias é necessário considerar condições extremas, para garantir que a integridade física da obra seja mantida frente à ação do mar durante sua vida útil, ou evitar custos de manutenção e reparos muito altos.

Os dados de ondas devem ser obtidos de dados de campo que permitam fixar direção, período, altura significativa e altura máxima da onda que exerce as maiores ações sobre as estruturas, denominada onda de projeto. O período de recorrência da onda de projeto não pode ser menor que o da expectativa da vida útil da obra, sendo mínimo de 50 anos.

A altura da onda de projeto a ser adotada no cálculo de estruturas de abrigo deve ser de Hs, altura de onda significativa (média aritmética das alturas do terço superior das ondas), para estruturas flexíveis de blocos naturais, ou artificiais. Para estruturas rígidas (muros e paredes), o valor recomendado é $\mathrm{H} 1$, que é a média aritmética das alturas do centésimo superior das maiores ondas (considera $\mathrm{H} 1=1,5 \times \mathrm{Hs})$.

A fim de decidir qual a melhor solução para a proteção da Rodovia SP-55, Alfredini (2006) estudou e comparou os resultados do espraiamento para a situação da praia natural, para a situação do projeto original de proteção, o muro de pedra argamassada, e para a solução proposta de um revestimento de alto da praia feito por enrocamento. Os gráficos consideram a altura de onda significativa de 2,50 m, um período de $8 \mathrm{~s}$ e incidência frontal. Também foi estimado o espraiamento com probabilidade de $2 \%$ de ocorrência de ser superado para esta tempestade.

Na situação da praia natural, sem nenhuma proteção, a declividade do talude no pós-praia, considerando período de inverno (junho e julho) é de $1 \mathrm{~V}: 4 \mathrm{H}$. Com base em U.S.Army (2002), obtém-se o gráfico dessa situação que pode ser visto na Figura 4.35. 


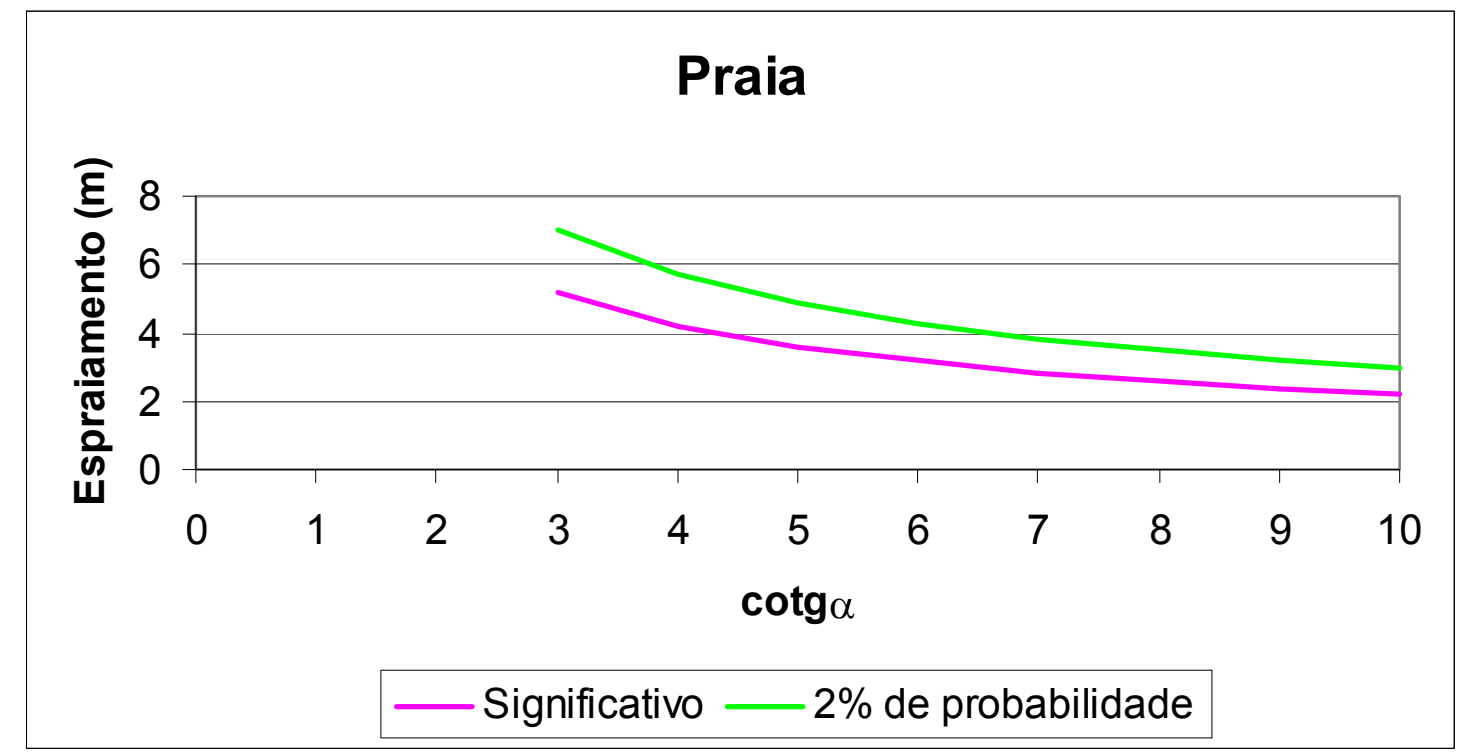

Figura 4.35 Estimativa do Espraiamento para diversos ângulos de Taludes de Praia FONTE: Alfredini, 2006

O projeto original de proteção da pista da Rodovia SP-55 consistia num muro de pedra argamassada, com paramento significativamente inclinado de $1 \mathrm{~V}: 0,8 \mathrm{H}$, constituindo-se numa estrutura rígida, com intensa refletividade, e muito vulnerável a solapamentos pela pouca resistência a tensões de tração. Na Figura 4.36 está apresentada a estimativa de espraiamento, segundo U.S.Army (2002), para o projeto original.

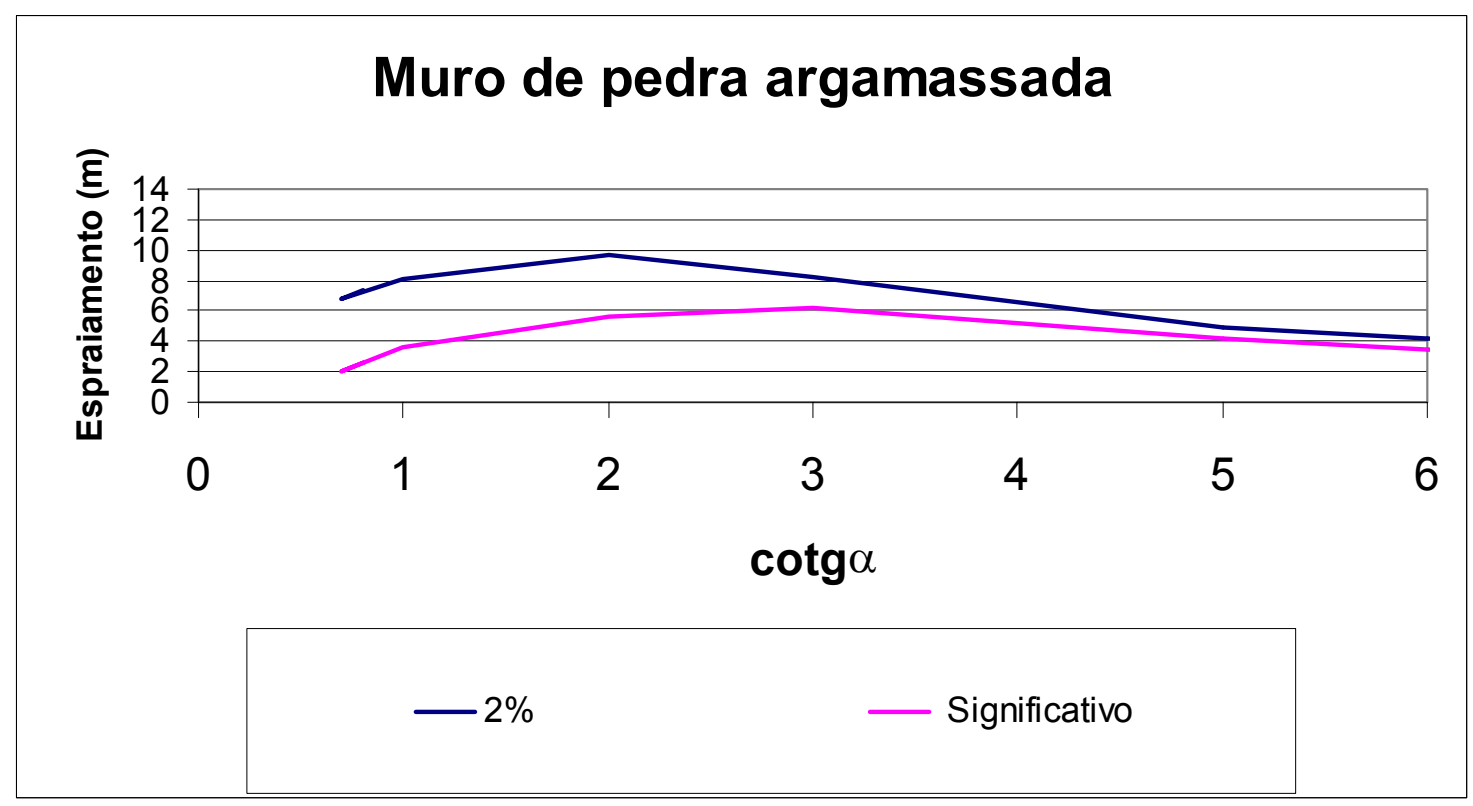

Figura 4.36 Estimativa de Espraiamento com revestimento de Muro de Pedra Argamassada FONTE: Alfredini, 2006 
A alternativa proposta consiste no revestimento feito por enrocamento, constituindo-se numa estrutura flexível, de fácil execução e manutenção, com declividade de rampa de $1 \mathrm{~V}: 1,5 \mathrm{H}$. Esta solução, pela sua flexibilidade a acomodações do terreno, contempla a incorporação dos trechos executados da base do muro de pedra argamassada (projeto original), provendo berma de proteção do pé do enrocamento. Na Figura 4.37 está o gráfico de estimativa de espraiamento nesse caso, segundo U.S.Army (2002).

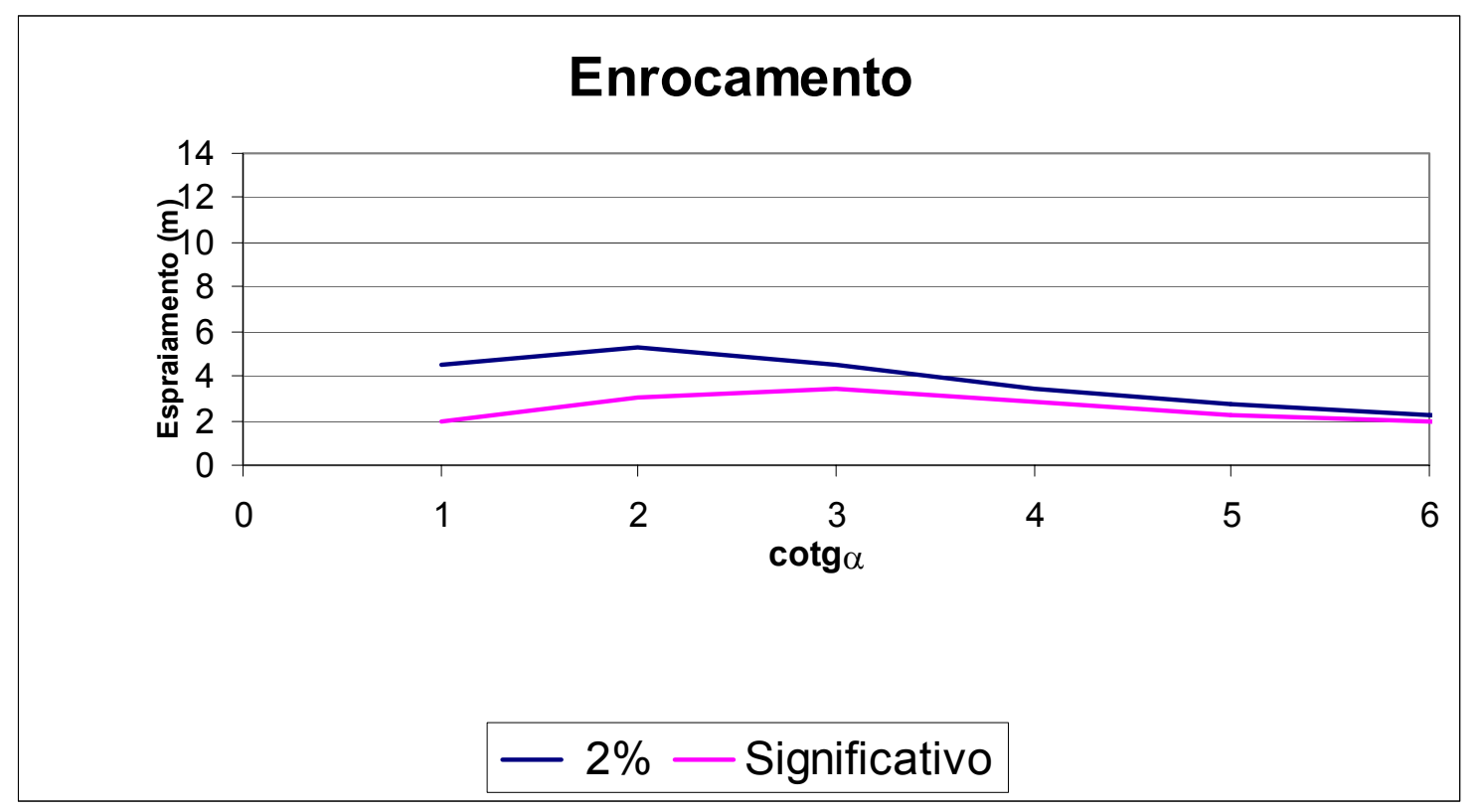

Figura 4.37 Estimativa de Espraiamento com revestimento de Enrocamento FONTE: Alfredini, 2006

A comparação dos espraiamentos, considerando uma altura de onda significativa de 2,50 m, um período de $8 \mathrm{~s}$ e incidência frontal, fornece os seguintes resultados, para uma situação equivalente à da tempestade na ressaca do início de junho:

- Praia natural: 4,30 m (significativo) e 5,80 m (2\%)

- Muro de pedra argamassada: 2,70 m (significativo) e 7,40 m (2\%)

- Enrocamento: 2,50 m (significativo) e 5,00 m (2\%)

Verifica-se que a proteção com talude de enrocamento oferece menores espraiamentos relativamente à concepção original de projeto, muro de pedra argamassada, bem como a situação da praia natural. Portanto, oferecem menores 
efeitos de refletividade, minimizando os riscos de erosão e, conseqüentemente, o solapamento da base da estrutura.

Assim, a alternativa considerada será o revestimento de alto da praia feito por enrocamento com talude de $1 \mathrm{~V}: 1,5 \mathrm{H}$. Na Figura 4.38 , observa-se um esquema desse tipo de estrutura.

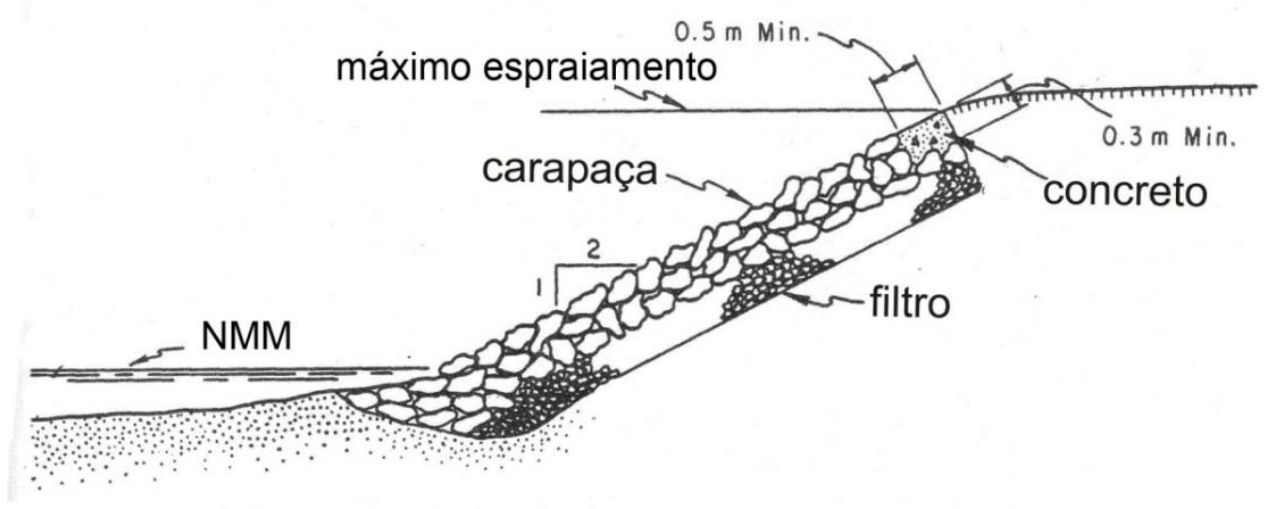

Figura 4.38 Revestimento de Alto da Praia de Enrocamento. FONTE: Alfredini, 2006

A complexidade da ação da agitação marítima, aliada à complexidade da forma de alguns blocos e à sua disposição aleatória no local estudado, torna praticamente impossível o cálculo rigoroso das forças atuantes nos blocos, que utilizam fórmulas de estabilidade baseadas em resultados teóricos e ensaios com modelos reduzidos.

Essas fórmulas, baseadas em simplificações teóricas e nos resultados desses modelos, permitem avaliar o peso dos blocos necessário para resistir à ação da onda de projeto.

Na Engenharia Costeira, a fórmula mais utilizada para o cálculo do peso de blocos, para enrocamentos submetidos à agitação da onda significativa, é a Fórmula de Hudson (4.9):

$$
\frac{H s}{\Delta \cdot D n_{50}}=(K d \cdot \cot \alpha)^{\frac{1}{3}}
$$


Onde:

$H s=$ amplitude da onda significativa $=2,50 \mathrm{~m}$;

$\Delta=\frac{\gamma s}{\gamma a}-1$

$\gamma s=$ peso específico do enrocamento $=2,7 \mathrm{tf} / \mathrm{m}^{3} ;$

$\gamma a=$ peso específico da água $=1,0 \mathrm{tf} / \mathrm{m}^{3}$;

$D n_{50}=$ diâmetro médio do cubo equivalente;

$\cot \alpha=$ inclinação do talude de enrocamento = 1,5 (1V:1,5H);

$K d=$ parâmetro equivalente a \% de danos na carapaça (em volume).

O CEM - Coastal Engineering Manual (2002) sugere, através de estudos de Melby e Mlaker (1997), um valor de $25 \%$ de coeficiente de variação na fórmula de Hudson, quando se aplica a blocos de enrocamento.

$\mathrm{Na}$ prática usual, o dimensionamento do peso dos blocos de enrocamento deve considerar, em primeira instância, a condição de 0 a $5 \%$ de dano em volume da carapaça, a ser reparado em caso de atuação da onda de projeto. Portanto, o parâmetro $\mathrm{Kd}=4,0$, segundo Shore Protection Manual. Com a aplicação da fórmula de Hudson, tem-se que o diâmetro médio de enrocamento será de 0,80 metros.

Com base nestes elementos, a proteção enrocamento com diâmetro característico de $0,80 \mathrm{~m}$ e peso específico de $2,7 \mathrm{tf} / \mathrm{m}^{3}$ resulta no peso médio característico do enrocamento de $P_{\text {médio }}=1,40$ tf, e considerando $25 \%$ de variação tem-se $P_{\text {máximo }}=1,75 \mathrm{tf}$ e $P_{\text {mínimo }}=1,05 \mathrm{tf}$.

Admitindo um critério mais econômico de proteção com enrocamento, foi considerada, para os dois metros superiores da estrutura, a condição de 10 a 15\% de dano em volume da carapaça, a ser reparado em caso de atuação da onda de projeto. Diante disso, a estrutura exigirá maior manutenção. Segundo Shore Protection Manual, o parâmetro $\mathrm{Kd}=6,6$, e o diâmetro do enrocamento resultante nesse critério é de 0,68 metros, que resulta nos seguintes pesos característicos de enrocamento: $P_{\text {médio }}=0,85 \mathrm{tf}, P_{\text {máximo }}=1,10 \mathrm{tf}$ e $P_{\text {mínimo }}=0,65 \mathrm{tf}$.

Recomenda-se a utilização de 2 camadas de blocos para constituir a carapaça da obra, bem como adequada distribuição granulométrica e das camadas de filtro. 
Para o dimensionamento do filtro e a construção da curva granulométrica (Figura 4.39) foram obedecidos os seguintes critérios contidos no "Coastal Engineering Manual" (2002):

$$
\begin{aligned}
& >\text { Permeabilidade }-\mathrm{d}_{15 \text { (filtro) }} / \mathrm{d}_{15 \text { (fundação) }}>5 \\
& >\text { Retenção }-\mathrm{d}_{15 \text { (filtro) }} / \mathrm{d}_{85 \text { (fundação) }}<5 \\
& >\text { Estabilidade interna }-\mathrm{d}_{60 \text { (filtro) }} / \mathrm{d}_{10 \text { (fundação) }}<10 \\
& >\text { Pedras grandes }-\mathrm{W}_{50 \text { (filtro) }} / \mathrm{W}_{50 \text { (fundação) }}<20
\end{aligned}
$$

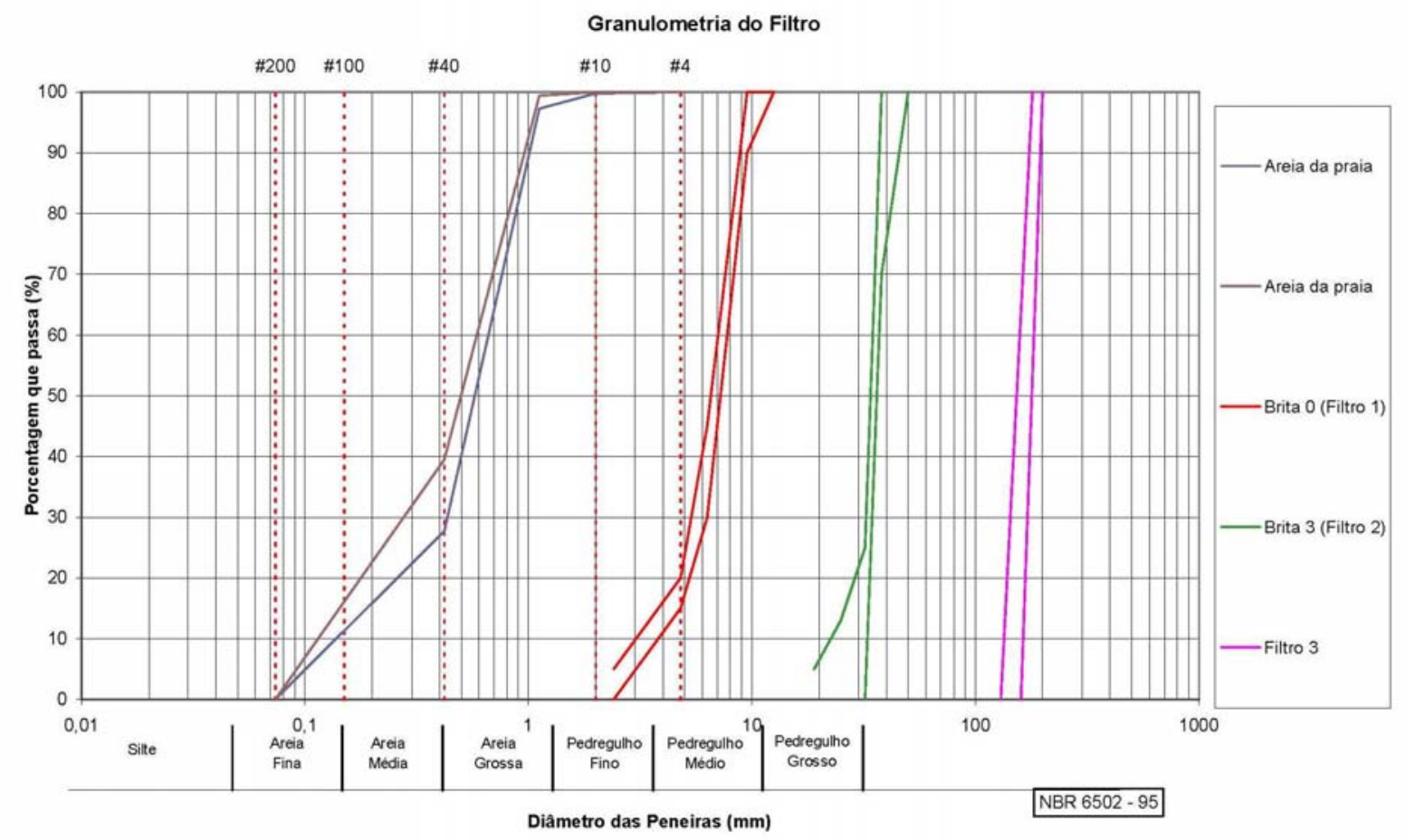

Figura 4.39 Curva Granulométrica FONTE: DER

Em resumo, o projeto executivo de reconstrução consiste em um revestimento flexível, feito por enrocamento, ilustrado nas Figuras 4.40, 4.41 e 4.42 abaixo. 


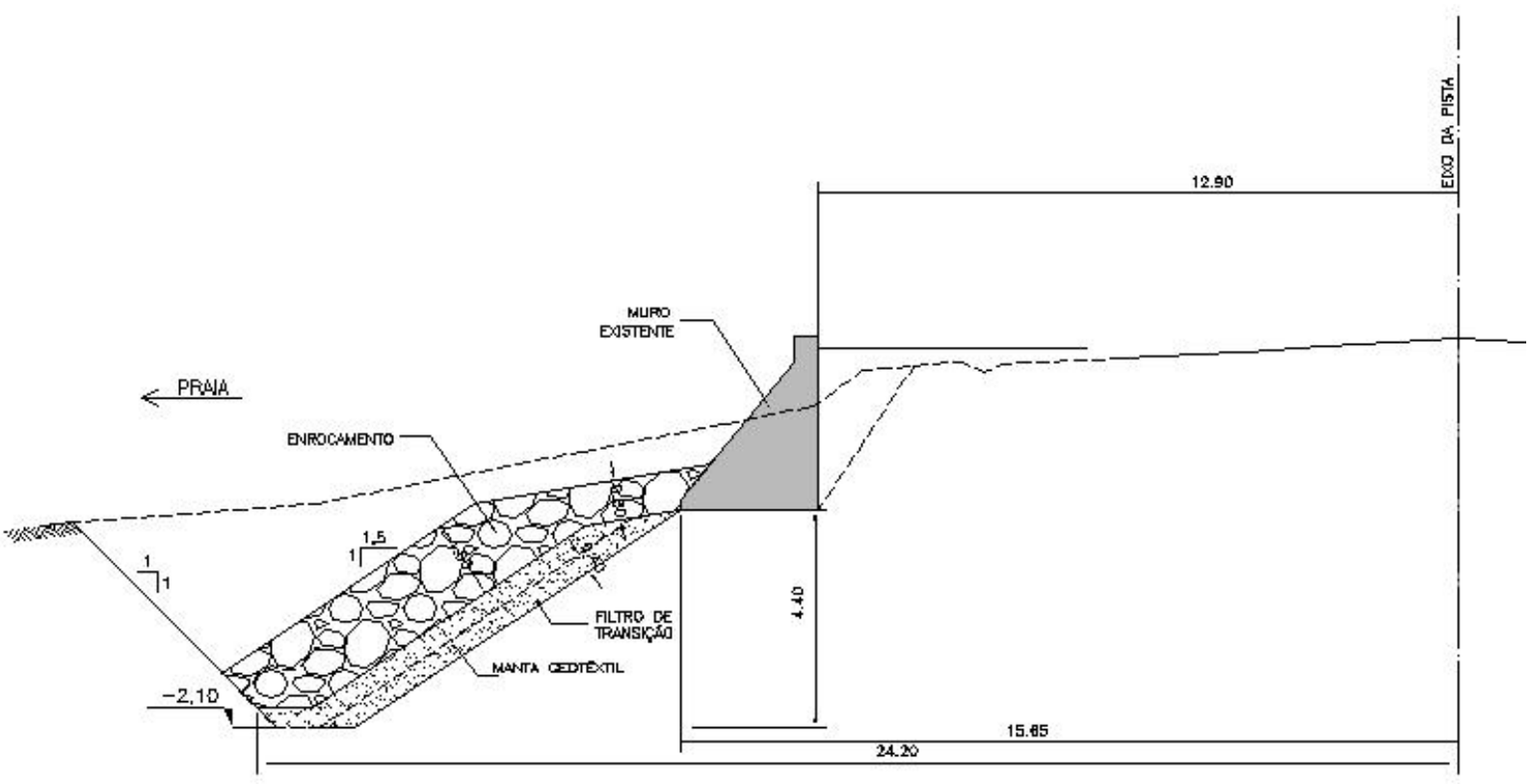

PROTECAO TIPO 1 (COM MURO)

Figura 4.40 Proteção Tipo 1

FONTE: DER / cadista "Chapolin" Colodo

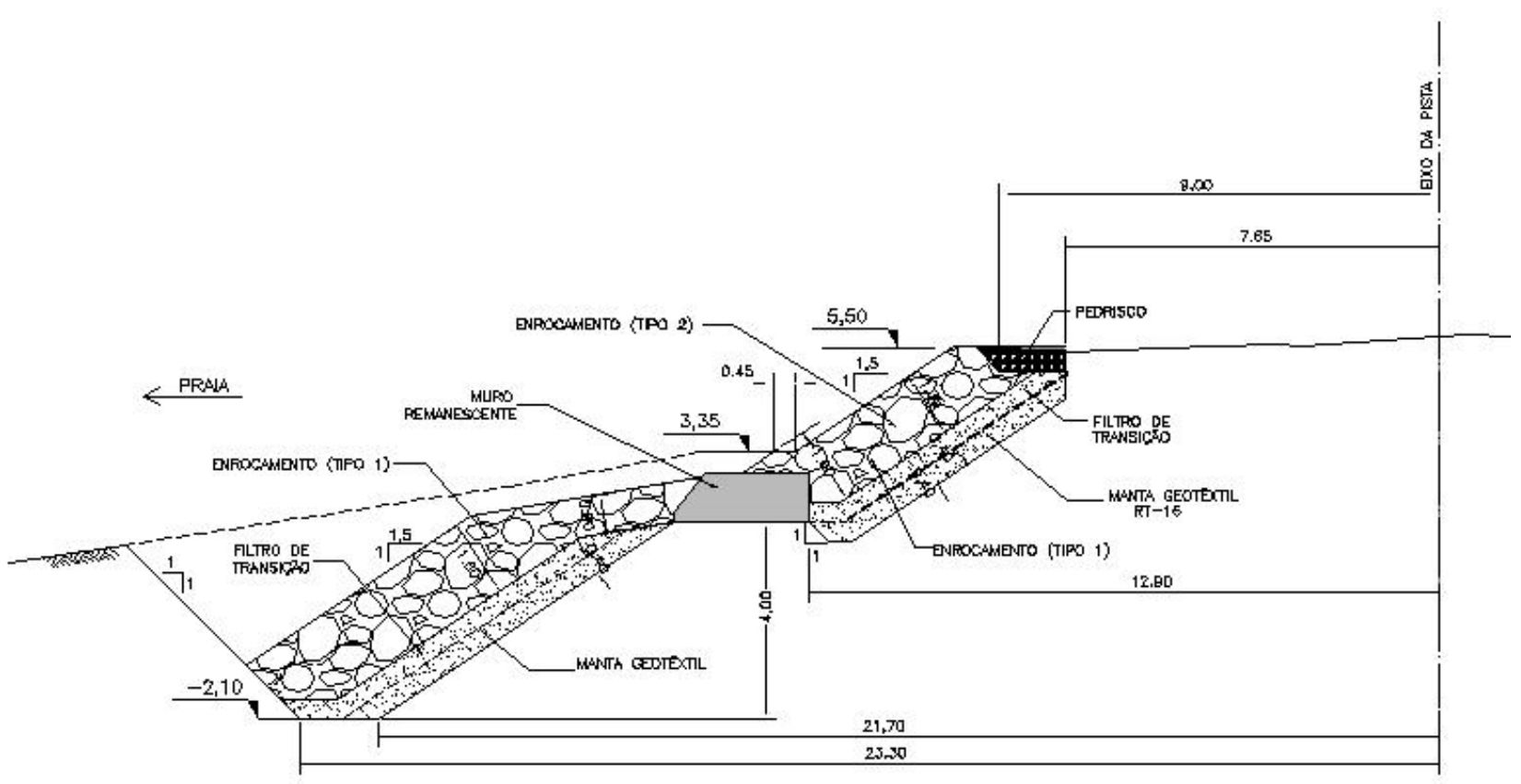

PROTECAO TIPO 2 (COM MURO REMANESCENTE)

Figura 4.41 Proteção Tipo 2

FONTE: DER / cadista "Chapolin" Colodo 


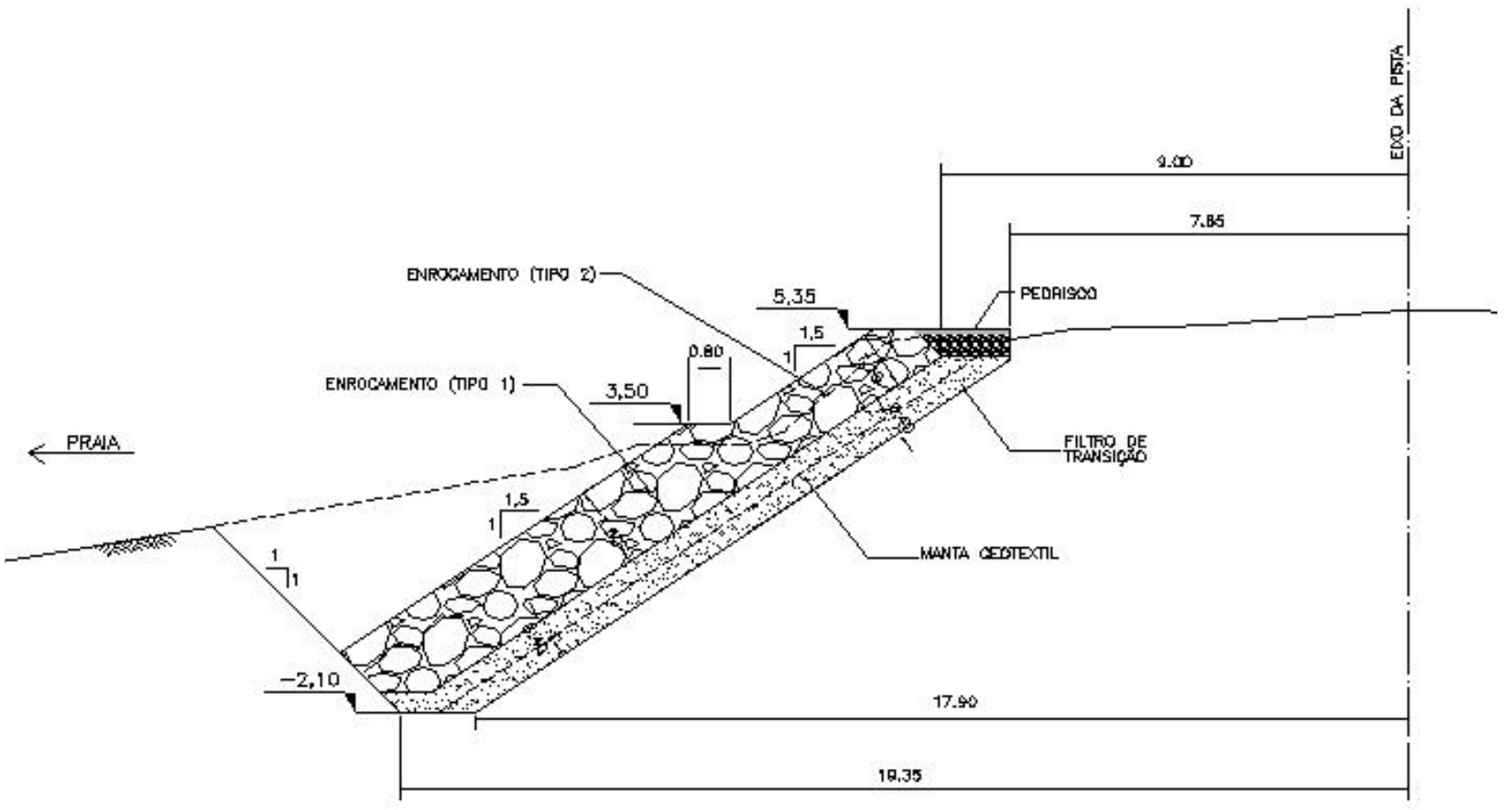

\section{PROTECAO TIPO 3 (SEM MURO)}

Figura 4.42 Proteção Tipo 3

FONTE: DER / cadista "Chapolin" Colodo

O revestimento com enrocamento tem uma extensão total de 500 metros e foi dividido em três trechos. O primeiro (Figura 4.40), sendo 80 metros de proteção tipo 1 (com muro), o segundo trecho (Figura 4.41), de 180 metros com proteção tipo 2 (com muro remanescente), e o terceiro (Figura 4.42) com 240 metros de proteção tipo 3 (sem muro). A divisão da estrutura em três trechos está esquematizada na Figura 4.44. Detalhe da proximidade da linha do mar à Rodovia SP-55 (Figura 4.43).

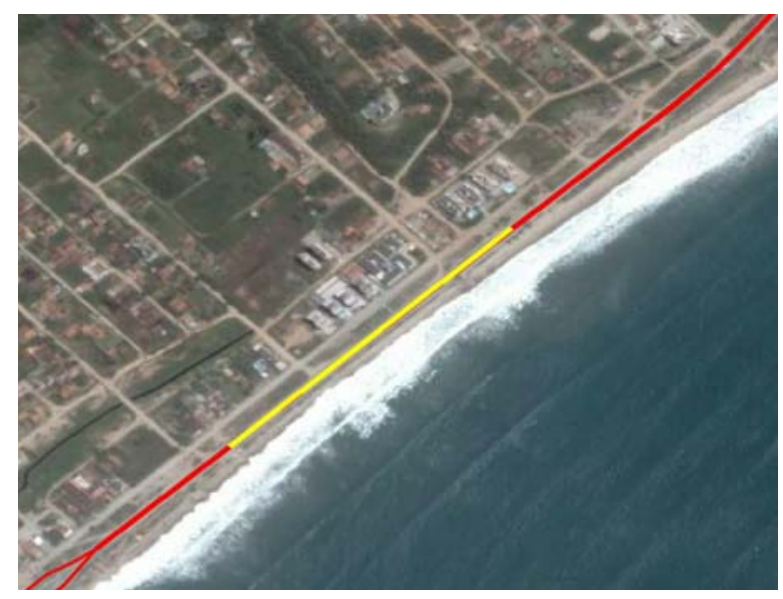

Figura 4.43 Proximidade do mar à SP-55 (ilustração sem escala) FONTE: Google Earth / DER / cadista "Chapolin" Colodo 


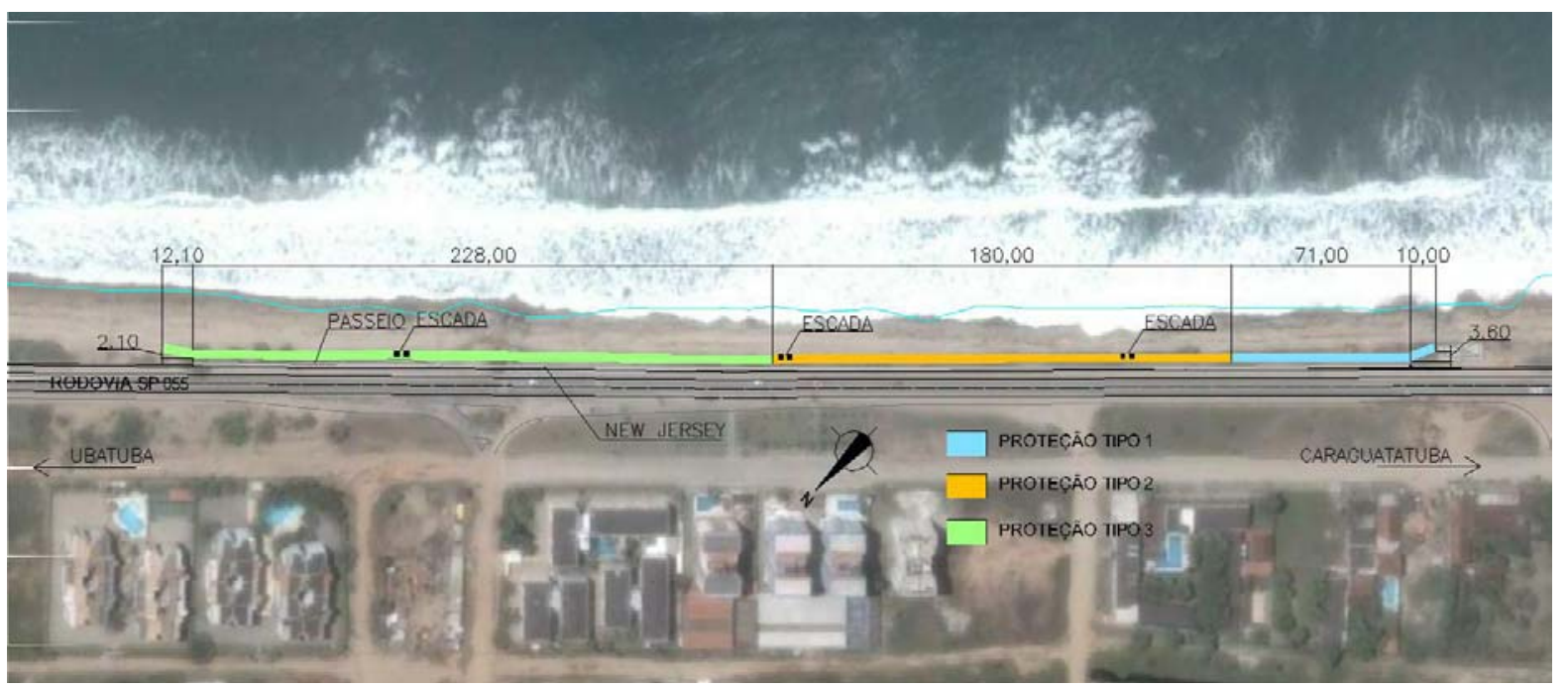

Figura 4.44 Vista Geral com o Projeto

FONTE: Google Earth / DER / cadista "Chapolin" Colodo

A mureta de concreto tipo "New Jersey", com cerca de $90 \mathrm{~cm}$ de altura acima do nível da calçada, constitui-se em importante complemento altimétrico da proteção contra o avanço do espraiamento sobre a pista.

É necessário levar em conta a disponibilidade de recursos de jazida de pedra (qualidade da rocha, dimensão e volume de blocos necessários e distância de transporte) nessa região, os equipamentos necessários para execução, e a possibilidade de manutenção. As pedreiras mais próximas são a Pedreira de Massaguaçu, aproximadamente $1 \mathrm{~km}$ do local; e a Pedreira de Jambeiro, aproximadamente $110 \mathrm{~km}$ do local erodido.

Reitera-se a necessidade de reparo da proteção de enrocamento em caso de ocorrência da onda de projeto, já que no seu dimensionamento foram admitidos danos parciais a estrutura. Ressalta-se também que pode ser necessária a manutenção do pé da estrutura no caso de solapamento, que pode ocorrer devido à erosão da praia resultante de ressacas excepcionais.

Estão previstas obras de acesso a praia (escadas) para o conforto e segurança dos usuários, obras de drenagem superficial, e calçamento junto à praia. A drenagem foi executada por meio de canaletas e descidas d'água, que visam minimizar a erosão na base da contenção. O projeto previu a utilização de rebaixamento com ponteiras drenantes ou bombas submersas, durante a execução das obras, por causa da cota da fundação ser inferior ao nível d'água. 
Finalmente, recomenda-se que os extremos longitudinais da obra, a barlamar e sotamar, sejam protegidos tendo uma transição de enrocamento mais leve até atingir distância não afetada pelo ataque de espraiamento das ondas.

\subsection{CONTINUIDADE}

Em 2007, houve vários casos de ressaca do mar no litoral paulista, e no trecho estudado o mar invadiu toda a pista de rolamento (local da obra), interditando temporariamente o tráfego local e comprometendo a estrutura da via. Abaixo, na Figura 4.45, temos um histórico fotográfico das ressecas e dos reparos emergenciais feitos na rodovia.
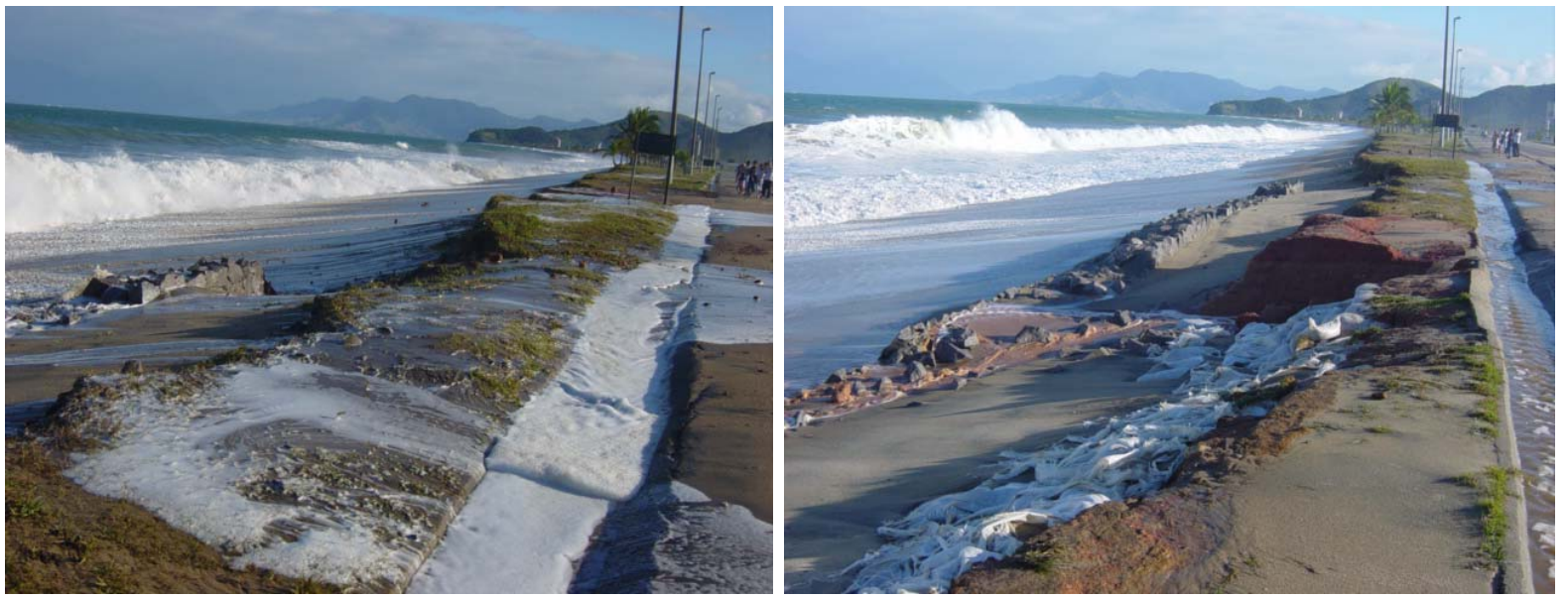

Ressacas em julho de 2007, período de Inverno
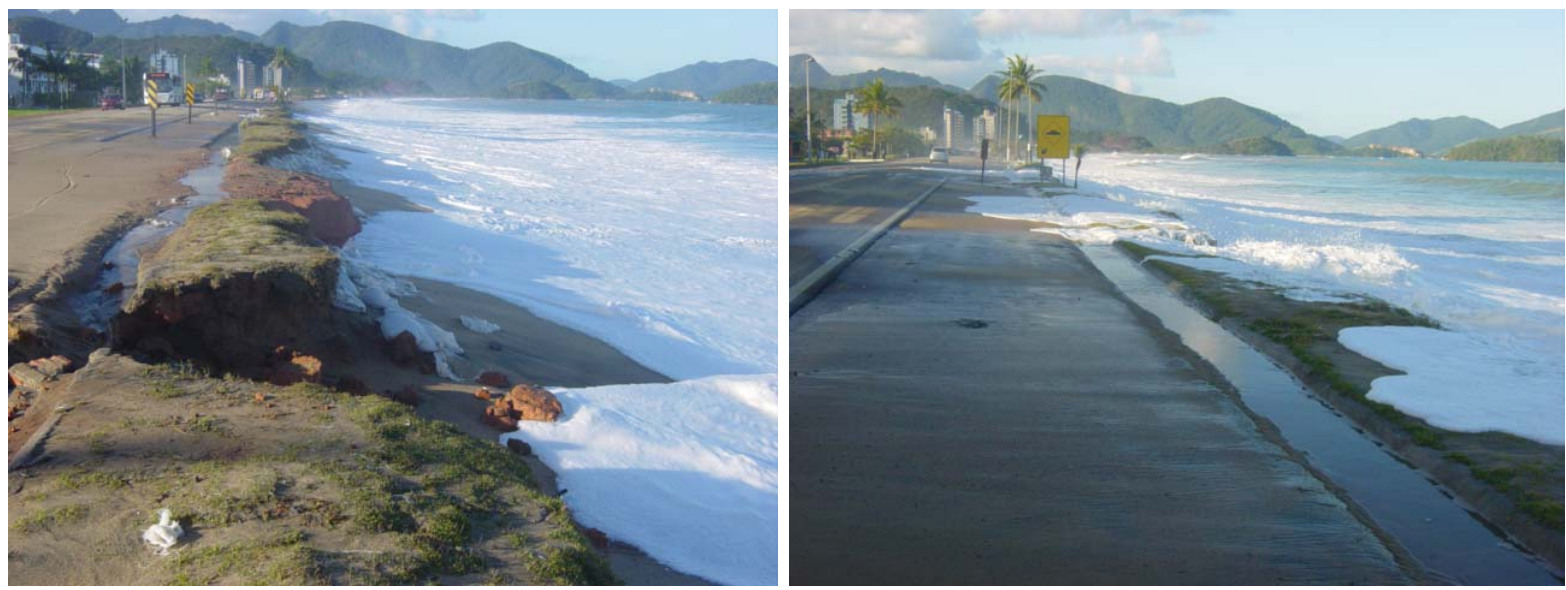

Detalhe do Espraiamento chegando na cota da Rodovia 

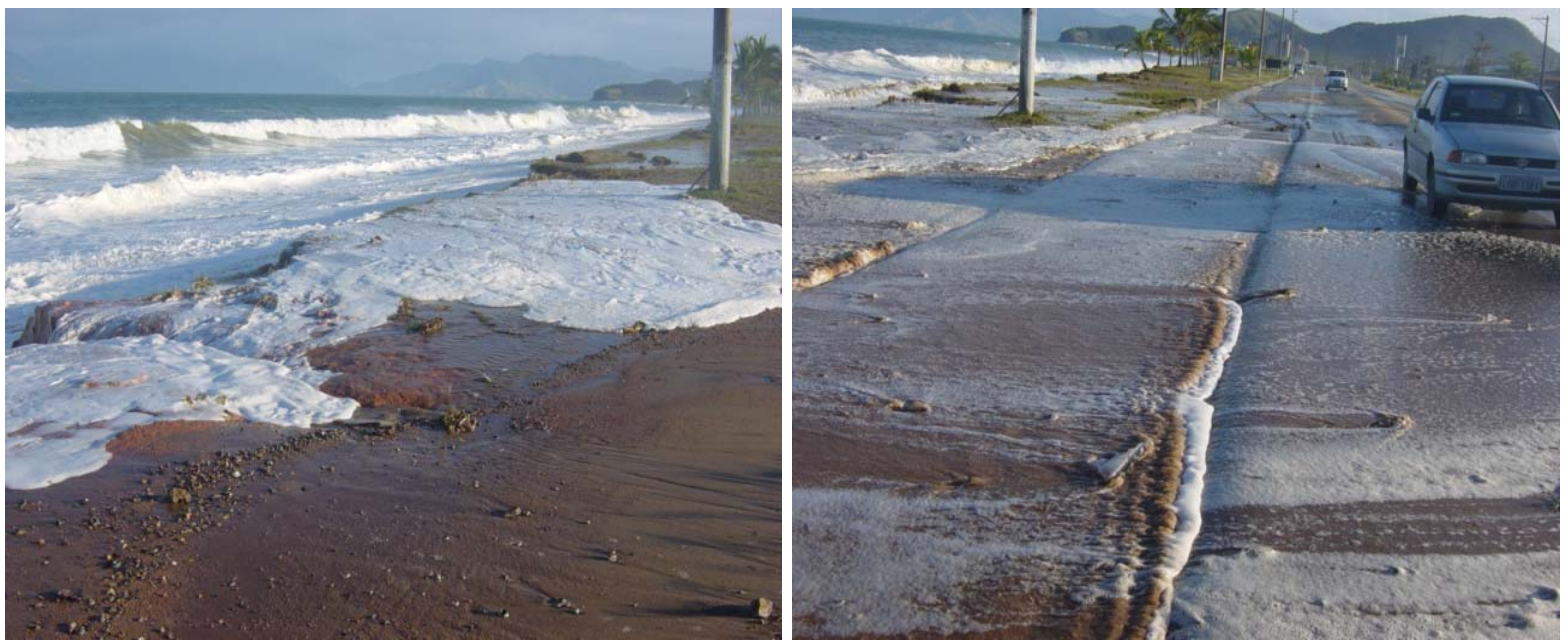

Invasão do mar na Pista de Rolamento
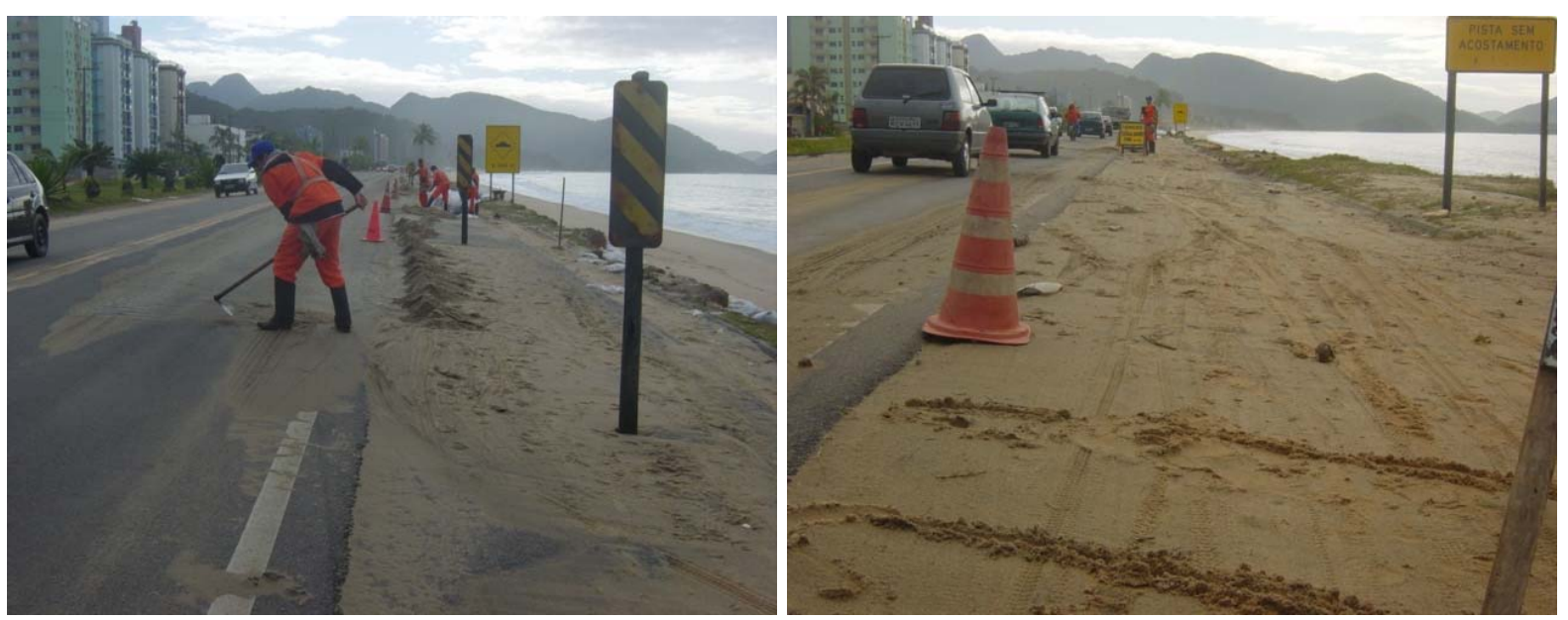

Pista sem Acostamento e Interdição do Tráfego
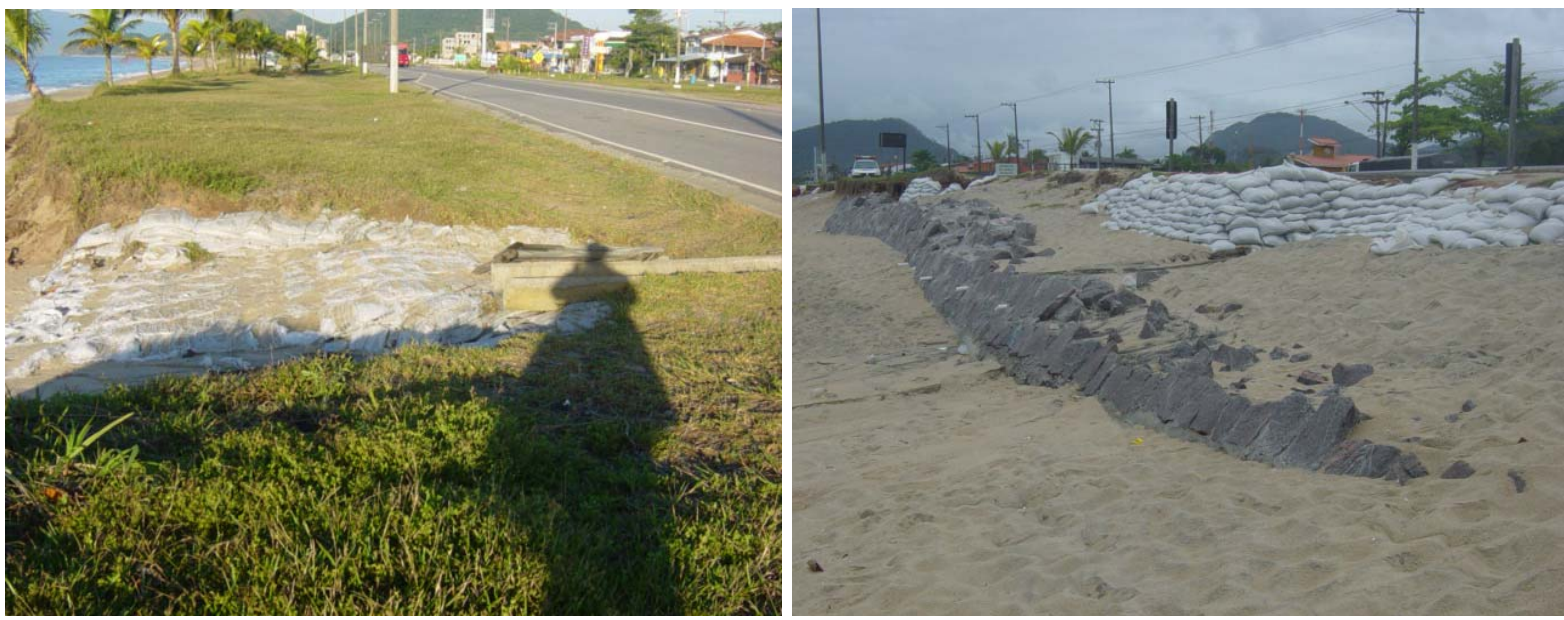

Medidas Emergenciais para conter a Erosão junto à Rodovia

Figura 4.45 Histórico Fotográfico das Ressacas e Medidas Emergenciais

Observou que as erosões avançaram em direção à rodovia, e o sistema de drenagem não suporta o volume d'água. Medidas emergenciais foram tomadas para tentar manter a integridade da Rodovia SP-55, e garantir a segurança dos usuários 
do local, enquanto se definia o projeto a ser implantado. Essas medidas foram desde a colocação de sacos de areia nos locais mais erodidos, como a interdição do acostamento da pista pelos órgãos responsáveis.

Em 2008 também se observou casos intensos de ressaca e interdição da Rodovia SP-55, trazendo desconforto para a população, sendo imprescindível a intervenção no local (ver Figuras 4.46, 4.47 e 4.48).
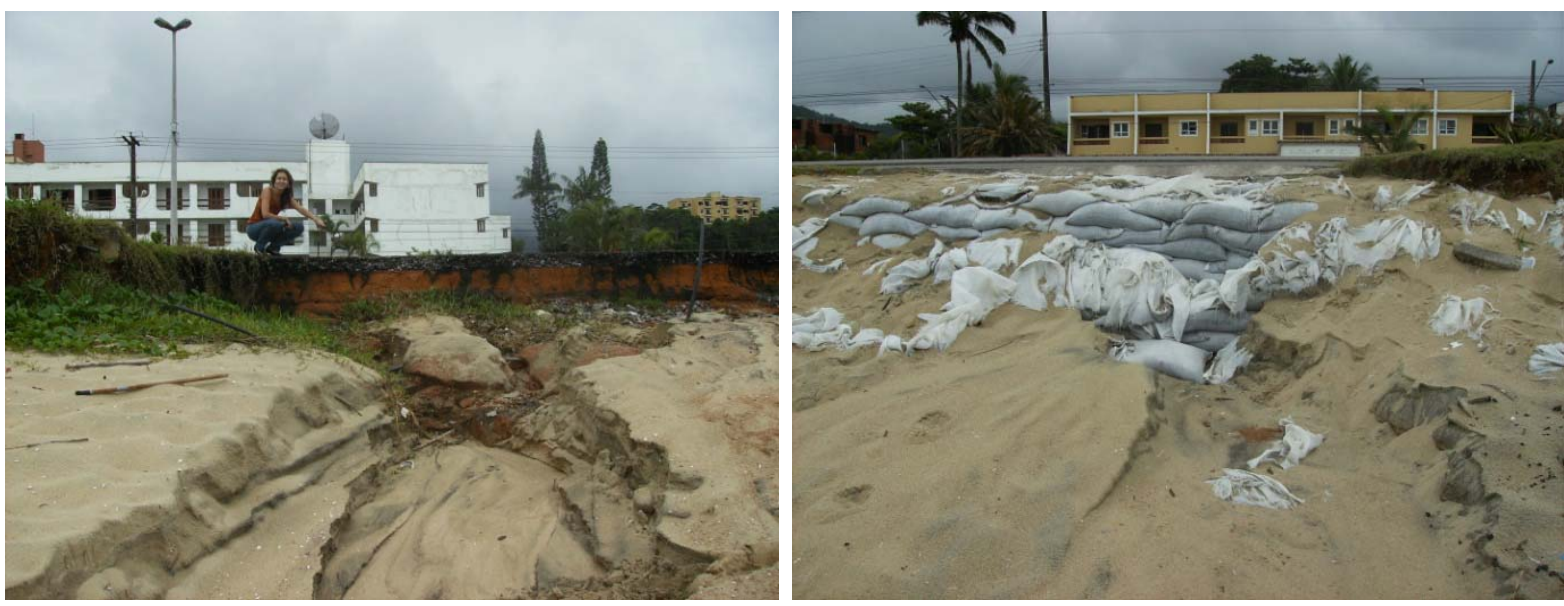

Figura 4.46 Erosões junto à Rodovia SP-55 e Sacos de Areia como Medida Emergencial
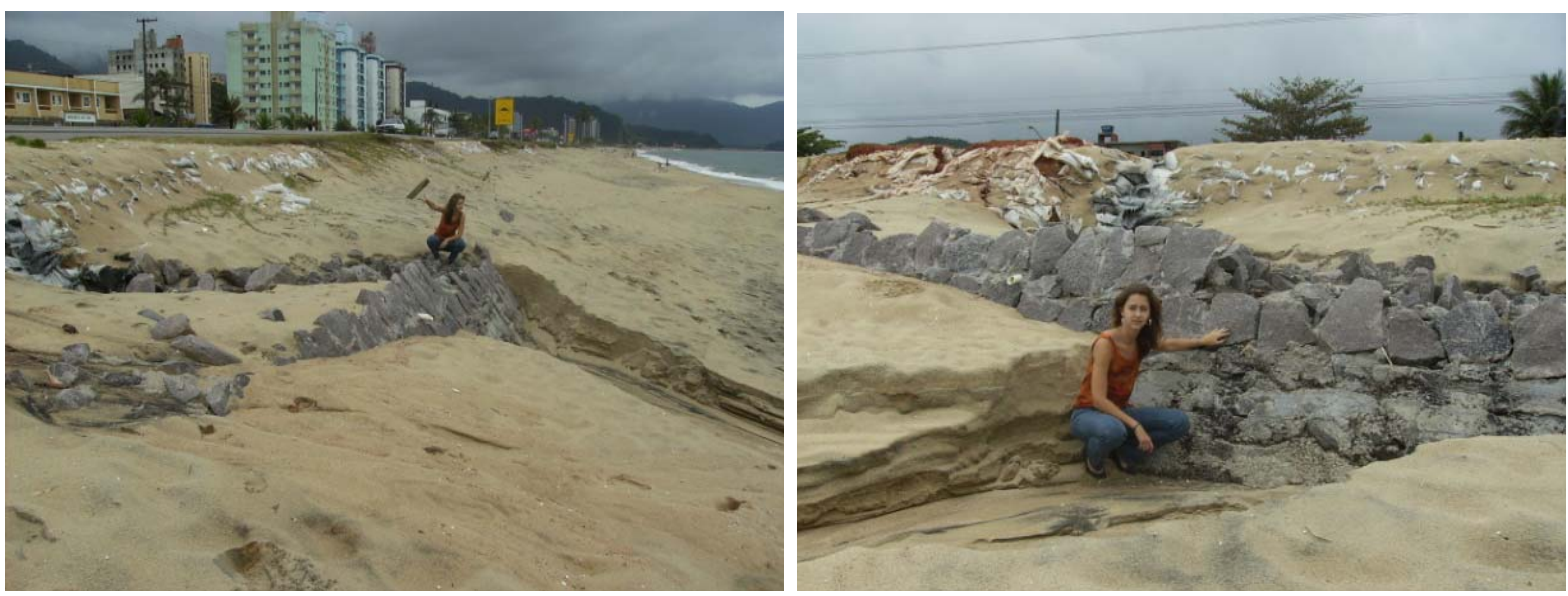

Observa-se o grande desnível da Rodovia em relação ao nível do mar. Detalhe do tamanho das pedras argamassadas do muro.

Figura 4.47 Vista Geral do Muro Remanescente 

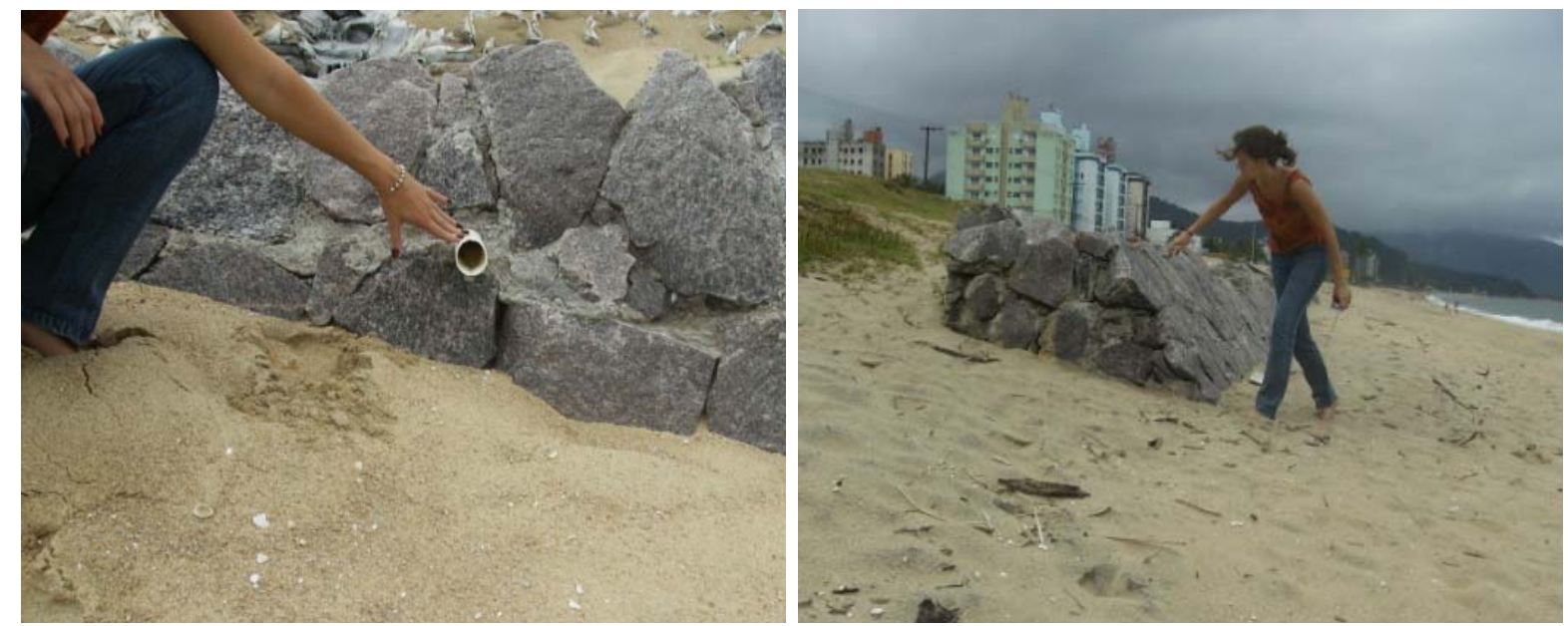

Figura 4.48 Detalhe do Barbacã no Muro e do Extremo longitudinal da Obra

Devido aos procedimentos legais e licitatórios, apesar do projeto já estar aprovado tecnicamente, a obra ainda não foi executada. O local continua em processo de erosão, sendo mantido pelos reparos emergenciais. 


\section{CAPÍTULO 5 \\ CONCLUSÕES}

De posse da avaliação dos possíveis e prováveis impactos que poderão vir a ocorrer devido à elevação do nível do mar, podem-se inferir algumas estratégias e preparar formas de minimização dos efeitos e até mesmo medidas mitigadoras para os impactos.

Porém, a ausência de estudos no litoral brasileiro, bem como de maneira mundial, focando o problema da elevação do nível do mar e suas conseqüências, dificulta a previsão a princípio dos impactos sobre os ecossistemas costeiros.

As estratégias dependem das questões técnicas, ambientais e sócioeconômicas. A construção e manutenção de estruturas de proteção costeiras são muito custosas e o mar é um adversário implacável, motivo pelo qual deverão ser feitos estudos minuciosos para todas as obras e projetos previstos.

As mudanças na linha de costa já apresentam impactos significativos que requerem decisões apropriadas para cada local. Para costas arenosas, as possíveis soluções contra a erosão abrangem desde a estabilização da linha de costa (através de engordamento artificial de praias ou estruturas protetoras) ao recuo da mesma. Todos são tecnicamente viáveis, mas a resposta apropriada será ditada por uma combinação de considerações sócio-econômicas e ambientais.

O recuo da linha de costa é tecnicamente viável desde que haja um planejamento adequado, analisando todas as questões econômicas e sociais, pois esse tipo de ação se justificaria para costas não desenvolvidas, ou pouco desenvolvidas. Esse cenário seria adequado no caso do valor da estrutura de proteção ser maior do que o valor da área a ser protegida.

No caso de estruturas protetoras, como espigões, quebra-mares, guiascorrentes, a areia tende a se acumular em torno das construções uma vez que seu fluxo é barrado, causando, na maioria das vezes, erosões graves a sotamar. Assim, 
é imprescindível a análise do transporte litorâneo longitudinal e o planejamento prevendo a mitigação dos possíveis efeitos adversos.

$O$ engordamento artificial de praias tem uma importante vantagem técnica que é ser uma intervenção flexível e adaptada à hidrodinâmica praial, portanto, não tem efeitos adversos, e, ao contrário, beneficia as praias adjacentes pela liberação gradual de material.

A análise dos estudos de caso, especialmente a erosão na Rodovia Dr. Manuel Hyppolito Rego - SP-55, na praia de Massaguaçu em Caraguatatuba, permitiu desenvolver diversas discussões e soluções sobre os paradigmas para os projetos de obras marítimas. Considerando o cenário brasileiro, e analisando os riscos da falta de uma intervenção no local, admitiu ser necessária uma obra emergencial e definitiva, já que se pretende manter a linha da costa por causa da rodovia. Modificar o traçado da mesma é inviável sócio-economicamente, tendo em vista os bairros que já se formaram ao longo da estrada, sendo considerado, portanto, um local já desenvolvido.

Sendo assim, a solução escolhida foi o revestimento do alto de praia, feito com enrocamento, pois é uma estrutura flexível e capaz de resistir à ação de tempestades e ondas mais severas. Também oferecem menores efeitos de refletividade, minimizando os riscos de erosão e, conseqüente, o solapamento da base da estrutura.

A complexidade da ação da agitação marítima torna praticamente impossível o cálculo rigoroso das forças atuantes. Aconselha-se a utilização da Fórmula de Hudson apenas no pré-dimensionamento da estrutura, devendo o dimensionamento final ser complementado com ensaios em modelo ou com resultados de experiências anteriores, nomeadamente obras de grande porte, como por exemplo, no caso do projeto de enrocamento de molhes guias-correntes na Foz do Rio Itanhaém.

Portanto, a proteção costeira deverá ser amplamente pensada, fazendo sempre uma combinação de questões técnicas, ambientais, políticas e sócioeconômicas. A medida protetora mais apropriada, para cada situação, poderá ser o engordamento artificial de praia com material adequado, pois oferece uma proteção de larga escala na maioria dos casos, senão, em todos. Entretanto, não significa que essa medida, isolada, seja sempre um procedimento suficiente. Na maioria das vezes, ela necessita do apoio de quebra-mares, diques ou muros e revestimentos de 
praia, devido à possibilidade da ação de marés meteorológicas, e também poderá precisar de espigões para quebrar o fluxo das correntes próximas à costa.

As costas marítimas sempre tendem a ajustar suas condições ao impacto das forças atuantes estabelecendo uma condição de equilíbrio.

Uma vez que não é possível controlar a natureza, a obra marítima deve ser projetada a partir dos paradigmas estudados para mitigar os danos advindos, e principalmente, os danos já ocorridos. É impossível estabelecer uma única solução, até porque cada localidade tem suas características e particularidades, sendo imprescindível, portanto, o estudo direcionado do problema em cada caso. Podemos arriscar, de qualquer maneira, que a melhor decisão é sempre o conjunto de várias soluções, onde uma estrutura complementa a outra, não esquecendo de analisar minuciosamente as áreas adjacentes, considerando as questões ambientais, políticas e sócio-econômicas. 


\section{REFERÊNCIAS BIBLIOGRÁFICAS}

ALFREDINI, P. "Obras e gestão de portos e costas, a técnica aliada ao enfoque logístico e ambiental". Editora Edgard Blücher, São Paulo, 2005.

ALFREDINI, P. "Diagnóstico sobre os efeitos da elevação do nível do mar decorrente do aquecimento global da atmosfera nos ecossistemas costeiros brasileiros - Estudo de Caso da Baía e Estuário de Santos e São Vicente (SP)”. São Paulo, 2005.

ALFREDINI, P. \& AMARAL, R. F. "Parecer de Consultoria Técnica para a caracterização dos processos litorâneos na Praia de Massaguaçu para subsidiar o estudo conceitual da obra de proteção da rodovia SP-55”. São Paulo, julho de 2006.

ALFREDINI, P. \& ARASAKI, E. "Diagnóstico sobre os efeitos da elevação do nível do mar decorrente do aquecimento global da atmosfera nos ecossistemas brasileiros Sub-região do litoral das regiões Sudeste e Sul para o Estudo de Caso da Baía e Estuário de Santos e São Vicente (SP)". Convênio Fundação Centro Tecnológico de Hidráulica, Instituição Parceira: Universidade de São Paulo, e CNPQ. Projeto de Conservação e Utilização Sustentável da Diversidade Biológica Brasileira - PROBIO - do Ministério do Meio Ambiente. São Paulo, 2005.

ALFREDINI, P.; ARASAKI, E.; AMARAL, R. F. "Mean sea-level rise impacts on Santos Bay, Southeastern Brazil - physical modelling study". Environmental Monitoring Assessment 144, 377-387p, 2008.

ARAÚJO, R. N. "A propagação e deformação das ondas, a dinâmica do transporte litorâneo e a evolução de linhas de costa em localidades do Litoral Paulista". Tese de Doutorado apresentada ao Departamento de Engenharia Hidráulica e Sanitária da Escola Politécnica da Universidade de São Paulo, São Paulo, 2005.

ARAÚJO, R. N. \& ALFREDINI, P. “Onda significativa em águas profundas para uso em projetos costeiros e portuários de localidades do litoral centro e sul do Estado de São Paulo”. São Paulo, 2005.

ARAÚJO, R. N. \& ALFREDINI, P. “Longshore sediment transport rate along Suarão and Cibratel Beaches, Itanhaém, SP, Brazil”. Journal of Coastal Research SI (35) Brazilian Sandy Beaches, 2003. Comportas Hidráulicas. 
ASSOCIAÇÃO BRASILEIRA DE NORMAS TÉCNICAS - ABNT. NBR 9782/1987. Ações em Estruturas Portuárias, Marítimas e Fluviais.

BRASIL / MARINHA / DIRETORIA DE HIDROGRAFIA E NAVEGAÇÃO - "Carta Náutica 1614 - Canal de São Sebastião - Escala 1:48110".

BRASIL / MARINHA / DIRETORIA DE HIDROGRAFIA E NAVEGAÇÃO - "Vagas e marulhos do Subquadrado de MARSDEN 37634". Banco Nacional de Dados Oceanográficos.

BRASIL / MARINHA / DIRETORIA DE HIDROGRAFIA E NAVEGAÇÃO - "Tábuas de Marés para o ano de 2006".

BRASIL / MINISTÉRIO DOS TRANSPORTES / CODESP - "Relação entre vários níveis de referência e o zero hidrográfico da CODESP". Santos, 1983.

BRASIL / MINISTÉRIO DOS TRANSPORTES / CODESP - "Serviço de Marés Registro mensal das observações referidas ao zero CODESP”.

BRASIL / MINISTÉRIO DOS TRANSPORTES / DNPVN / INPH "Campanha de medições hidráulicas na Baía de Santos - 1972/1973”. Rio de Janeiro, 1974.

BRASIL / MINISTÉRIO DOS TRANSPORTES / INPH - "Relatório Final das medições de ondas, ventos e marés realizadas no período de maio de 1977 a dezembro de 1978 em Macaé (RJ)". 1979.

DEPARTMENT OF THE ARMY .U.S. Army Corps of Engineers. "Coastal Engineering Manual". Washington, DC, 30 April 2002.

DER / SP - Departamento de Estradas de Rodagem do Estado de São Paulo.

DNH. Diretoria de Hidrografia e Navegação, Centro de Hidrografia da Marinha (CHM), Banco Nacional de Dados Oceanográficos, São Paulo.

EFEITO ESTUFA E A CONVENÇÃO SOBRE MUDANÇA DO CLIMA. Banco nacional de desenvolvimento econômico e social área de planejamento assessoria 
especial de meio ambiente / ministério da ciência e tecnologia gabinete do ministro / coordenação de pesquisa em mudanças globais /setembro de 1999.

FEMAR. "Catálogo de Estações Maregráficas Brasileiras". Rio de Janeiro, 2000.

GARCIA OCCHIPINTI, A. “Considerações sobre marés em Ubatuba”. São Paulo, sd.

HARARI, J. "Dados de maré observada e prevista para o marégrafo de Ubatuba do IOUSP em 1992 e 1993". São Paulo.

IBGE. "Anuário Estatístico do Brasil." Fund. Inst. Brasil. de Geogr. e Estat. - Ano 1 (1908/1912). Diretoria Geral de Estatística do Ministério da Agricultura, Indústria e Comécio. 1994.

IPCC. Intergovernmental Panel on Climate Change. "Climate Change and biodiversity “. IPCC Technical Paper V, 2002.

KENNEDY, V.S.; TWILLEY, R. R.;KEYPAS, J. A.; COWAN, J. H.; HARE, S.R. "Coastal and marine ecosystems \& global climate change - Potential effects on US resources" - Report of the Pew Center on Global Climate Change, Arlington, VA. 51p, 2002.

MARTINS, C. C. "Morfodinâmica e transporte de sedimentos em praia refletiva: Estudo de caso na Praia da Sununga, Litoral Norte do Estado de São Paulo". São Paulo, 2005.

MASSIE, W. W. "Coastal Engineering Manual”. 1982.

MESQUITA, A. R. \& HARARI, J. "Tides and tide gauges of Cananéia and Ubatuba"Brazil (LAT. $24^{\circ}$ ). Relatório Interno do Instituto Oceanográfico, 1983.

NEUMANN, J.E.; YOHE, G.;NICHOLS, R.; MANION, M. "Sea level rise and global climate change". Pew Center on Global Climate Change, Arlington, VA, 2000.

SILVA, P. C. M. "Relatório Final sobre a agitação do mar em Tubarão". Rio de Janeiro, 1972. 
SOUZA, C. R. G. "As células de deriva litorânea e a erosão nas praias do Estado de São Paulo". São Paulo, 1997.

SOUZA, C. R. G. "Considerações sobre os processos sedimentares quaternários e atuais na região de Caraguatatuba, Litoral Norte do Estado de São Paulo". São Paulo, 1990.

U. S. ARMY “Coastal Engineering Manual”. Washington, 2002.

U. S. ARMY "Shore Protection Manual". Washington, 1984.

MUEHE, DIETER. “Erosão e Progradação do Litoral Brasileiro", 2005.

MULDER, J. P. M.; NEDERBRAGT, G.; STEETZEL, H. J.; Van KONINGSVELD, M.; WANG, Z. B. - "Different implementation scenarios for the large scale coastal policy of The Netherlands". Proceedings of the $30^{\text {th }}$ International Conference on Coastal Engineering, 2006.

TRANSESP. Pesquisa e Planejamento de Transportes do Estado de São Paulo S.A. "Projeto Básico do Porto Piloto de São Sebastião". Relatório Final, novembro de 1978.

U.S. ARMY/CORPS of Engineers, Costal Engineering Research Center (CERC). "Coastal Engineering Manual" U.S. Government Printing Office, 2002.

U.S. / NATIONAL RESEARCH COUNCIL / COMMITTEE ON ENGINEERING IMPLICATIONS OF CHANGES IN RELATIVE MEAN SEA LEVEL "Responding to changes in sea level - Engineering Implications". September 1987.

VELLINGA, P. \& ZITMAN, T. J. "Coastal zone response to an increasing sea level rise". Proceedings of the 21 th International Conference on Coastal Engineering, 1988.

16 YEARS OF SCIENTIFIC ASSESSMENT IN SUPPORT OF THE CLIMATE CONVENTION. December, 2004. 